\title{
Çukurova Âyânları III: Hasanpaşazâde Ahmet Bey
}

\author{
Y1lmaz Kurt*
}

\begin{abstract}
Öz
Hasanpaşazâdeler, 1750 yıllarında Karslızâdeler olarak ortaya çıkmış bir âyân ailesidir. Aileden Hasan Ağa'nın 1770 yılında Adana beylerbeyi olmasından sonra aile Hasanpaşazadeler olarak anılmaya başlamış ve en parlak günlerini Ahmet Bey'in Adana âyânlığg ve Adana mütesellimliği yaptığı 1793- 1812 yılları arasında yaşamıştır.

1812 yılında Ahmet Bey'in ölümü üzerine yerine kardeşi Mehmet Bey Adana mütesellimi olmuştur. Mehmet Bey’in devlet ile ters düşerek sürgün edilmesi üzerine de Ahmet Bey’in oğlu Hacı Ali Bey Adana mütesellimliğini yürütmüştür.

Bu makalede ele alınan 60 belge Hasanpaşazâde Ahmet Bey'in ilk yıllarına ilişkin olup bir âyân ailesinin devletle olan ilişkilerini nasıl yürüttüğü ve mukataalar veya iltizamlar satın alarak bölgede nasıl etkin bir konum kazandığını gösteren belgelerdir. Ahmet Bey'in mütesellimlik beratları bir âyân ailesinin mütesellimliğe niçin ve ne şekilde atandığını gösteren önemli belgelerdir.

Hasanpaşazadeler âyân ailesi Adana Müftüsü İshak Efendi kolundan varlığını devam ettirmiştir. Bugün bölgede Ramazanoğlu, Ener, Tarımer, Oral, Uygur gibi soyadları taşıyan aileler bu aileden gelmektedirler.
\end{abstract}

Anahtar Kelimeler: Çukurova, âyân, Karslızâdeler, Hasanpaşazâde Ahmet Bey, Hasanpaşazâde Mehmet Bey, Adana mukataaları, mütesellim.

\section{Çukurova Âyânları (Notables) III: Hasanpaşazâde Ahmet Bey}

\begin{abstract}
Hasanpaşazâdes is an ayan family that emerged in the 1750s as Karslizâdes. After Hasan Ağa, who was a member of the family, became the governor-general of Adana, the family began to be called as Hasanpaşazades and the most gorgeous days of the family were between the years of 1793-1812 when Ahmet Bey was ayan and mütesellim (exciseman) of Adana.

After the death of his brother Ahmet Bey, Mehmet Bey became the mütesellim of Adana in 1812 . Since Mehmet Bey could not get along with the state and was banished, Hac1 Ali Bey, son of Ahmet Bey, took over the duty of Adana Mütesellimliği.
\end{abstract}

Prof. Dr., Ankara Üniversitesi, Dil ve Tarihi-Coğrafya Fakültesi, Tarih Bölümü Emekli Öğretim Üyesi, Ankara/TÜRKIYE, yilmazkurt2002@yahoo.com ORCID: 0000-0001-9595-7398

DOI: $10.37879 /$ belgeler.2022.39 
Sixty documents scrutinized in this article are related to the first years of Ahmet Bey and indicate the relationship between the state and an ayan family and the active role of Ahmet Bey in the region by buying mukataas and iltizams. The berats of Ahmet Bey are crucial documents that indicate why and how an ayan family is appointed to position of mütesellimlik.

Hasanpaşazade ayan family's lineage continued with İshak Efendi, mufti of Adana. Today, in the region, people who have surnames such as Ramazanoğlu, Ener, Tarımer, Oral, Uygur are the descendants of this family.

Keywords: Çukurova, ayan, Karslizâdeler, Hasanpaşazâde Ahmet Bey, Hasanpaşâzade Mehmet Bey, mukataa of Adana, mütesellim.

\section{Giriş}

Çukurova siyasi tarihinde önemli etkileri olan Hasanpaşazâdeler âyân ailesi hakkında bugüne kadar birkaç yayın yapıld ${ }^{1}$. Bu yüzden ailenin geçmişi hakkında ayrıntılı bilgi vermek yerine makaleye konu olan Hasanpaşazâde Ahmet Bey’i tanıtacak ve yayına hazırladığımız belgelerin genel bir değerlendirmesini yapmakla yetineceğiz².

Aile, Kars-1 Maraş (Kadirli) yöresinden geldikleri için 1760 yıllarına kadar Karslızâdeler olarak anılmaktaydı. Karslızâde Hacı Ali Ağa’nın oğlu Hasan Ağa 1769 yılında Üzeyir (İskenderun, Payas) sancakbeyi ve arkasından Adana beylerbeyi olunca aile bu tarihten sonra daha çok Hasanpaşazâdeler diye anılmaya başladı. Bundan önce yayınlamış olduğumuz belgeler ailenin Karslızâdeler olarak anıldıkları döneme ait belgeler ile Hasan Paşa'nın Adana Beylerbeyiliği ve Özi Muhafızlığı dönemi ile ilgili belgelerdi.

Hasan Paşa'nın oğulları Abdullah Paşa ile kardeşi II. Hacı Ali Bey dönemine ait daha az say1da belge bulunmaktaydı. Ancak Abdullah Paşa'nın oğulları Ahmet Bey ve Mehmet Bey hakkında Cumhurbaşkanlığı Devlet Arşivleri Başkanlığı Osmanlı Arşivi (COA)'nde; eski adıyla Başbakanlık Osmanlı Arşivi (BOA) kataloglarında ve Adana Şer'iye sicillerinde pek çok belge bulunduğunu gördük. 58 numaralı Adana Şer’iye Sicili sanki özel olarak Ahmet Bey için tanzim edilmiş gibiydi. Bu yüzden çalışmamızın başlangıcında Ahmet Bey ve Mehmet Bey dönemine ait belgeleri bir makalede toplamayı tasarlamışken bu makaleyi sadece Ahmet Bey ile ilgili belgelere ayırmak zorunda kaldık. Bu durumda bile bulduğumuz belge sayısı 100’ün

1 Yılmaz Kurt, "Çukurova'da A‘yânlık Mücâdelesi: Hasanpaşazâdeler”, XV. Türk Tarih Kongresi Kongreye Sunulan Bildiriler, 20-24 Eylül 2010 Ankara, 4. Cilt-1. K1sım, Osmanlı Tarihi, Türk Tarih Kurumu Yay., Ankara 2010, s. 1259-1278; Yılmaz Kurt-Ertan Ünlü, "Çukurova Âyânları I: Hasanpaşazâdeler İle İlgili Arşiv Belgeleri I”, Belgeler, C XXXIII/S. 37 (2012), Türk Tarih Kurumu Yayınları, Ankara 2014, s. 57-116; Y1lmaz Kurt- Ertan Ünlü, “Çukurova Âyânları II: Hasanpaşazâdeler (Karslızâdeler) İle İlgili Arşiv Belgeleri II”, Belgeler, C XXXIV/S. 38 (2013), Türk Tarih Kurumu Yayınları, Ankara 2016, s. 17- 86.

2 Bu makalenin hazırlanması sırasında bana yardımcı olan Doktora öğrencimiz Ümit Katırancı ve Yükseklisans öğrencimiz Mehmet Çetinkaya’ya teşekkür ederim. Hatalı ve eksik sayfaların zamanında ve mükemmel olarak yeniden çekilmesini sağlayan Cumhurbaşkanlığı Arşivi yöneticilerine ve çalışanlarına da minnet borçluyum. 
üzerine çıkınca konu olarak aynı özellikleri taşıyan deyn temessükü, tahvil belgesi gibi birçok belgeyi çıkardık. Ancak Ahmet Bey'in mukataalar üzerinden Adana'daki siyasi ve ekonomik etkinliğini ortaya koyması açısından bu belgelerden önemli gördüklerimizi buraya almakta yarar gördük.

Bu makaleye konu olan Ahmet Bey, 1793 yılından 1812 y1lına kadar Adana'da çoğu zaman unvanı mütesellim olsa bile gerçekte bir vali gibi hüküm sürmüştür. Adana mütesellimi Karc1 Mehmet Ağa’nın idamından sonra 1793 yılının Aralık ayında Rumeli'de bulunan Anabolu kalesinin muhafazası hizmeti sebebiyle adından bahsedilmiştir ${ }^{3}$. 1812 yılında Ahmet Bey ölünce ${ }^{4}$ Adana mütesellimliği görevi kardeşi Mehmet Bey’e verilmişti. 1826 yılından 1832 yılına kadar da Ahmet Bey’in oğlu III. Hacı Ali Bey Adana ve Tarsus mütesellimi olarak bütün Çukurova'yı denetimi altına almıştı.

$\mathrm{Bu}$ makalede Ahmet Bey ve dönemine ait 60 belgeye yer vereceğiz. Geri kalan belgeleri ise ayrı bir makalede vermenin daha doğru olacağını düşündük. Hasanpaşazâde Mehmet Bey ile ilgili belgeleri ayrı bir sayıda yayınladıktan sonra serinin son makalesini ise Hasanpaşazâde III. Hacı Ali Bey ile ilgili belgelere ayıracağız. 1832 yılında III. Hacı Ali Bey'in İstanbul'a sürgün edilmesi ile birlikte ailenin askeri kanadı sona erdi ${ }^{5}$. Aile Adana Müftüsü İshak Efendi kolundan günümüze kadar gelmiştir ${ }^{6}$. Cumhuriyet döneminde aileden pek çok milletvekili, belediye başkanı, müftü, devlet adamı ve subay yetişmiştir. Aile bugün kendisini daha çok Ramazanoğlu sülalesi üzerinden tanımlamaktadır? .

Hasanpaşazâde Ahmet Bey’in adının geçtiği ilk belge 1788 tarihlidir. Bu belgede Ahmet Bey ve kardeşi Mehmet Bey’in Ramazanoğulları Evkāfı'na ait Yeni Han yakınında bulunan bazı dükkânlarının kiracısı olan Çelebi Ağa'nın ölümü üzerine bu dükkânların işletilmesi hakkını Serturnayî Halil Ağa ve kardeşinin oğlu Mustafa Ağa ile birlikte ortaklaşa satın aldıklarını görmekteyiz. Karslızâdeler veya daha sonraki adlarıyla Hasanpaşazâdeler 1850'lerden sonra kendilerini doğrudan doğruya Ramazanoğulları'na bağlayacak olmaları bakımından bu belge önemlidir8.

Sayda ve Şam taraflarında çıkan karışıklığın bastırılması için acil olarak asker gerekince Adana'dan 800 piyade askeri yazılmasına gerek duyulmuştu. Bu 800 askerin 500'ünü Adana mü-

3 Yilmaz Kurt, agm., s. 1265.

4 Ahmet Bey’in ölüm tarihi bir belgede Selh-i Şevvâl 1226/ 16 Kasım 1811 olarak gösterilmiştir. Oysa ki Câbî Ömer Efendi'ye göre 1812 yılında ortaya çıkan Sarıcaoğlu İsyanı sırasında Sarıcaoğlu Adana'ya kaçmış ve Ahmet Bey’e sığınmıştı. Bk. Câbî Ömer Efendi, Câbî Tarihi, C II, haz. Mehmet Ali Beyhan, TTK Yayınları, Ankara 2006, s. 896- 897. Burada belgenin tarihini esas alarak 16 Kasım 1811 tarihini Ahmet Bey'in ölüm tarihi olarak kabul etmek daha doğru görünmektedir.

5 Kasım Ener, Tarih Boyunca Adana Ovasına (Çukurova'ya) Bir Bakış, 7. bs., İstanbul 1986, s. 290.

6 Ener, age., s. 283.

7 Yılmaz Kurt, "Ramazanoğulları'nın Sonu”, Ramazanoğulları Beyliği, Uluslararası Orta Anadolu ve Akdeniz Beylikleri Tarihi, Kültürü ve Medeniyeti Sempozyumu-III, Editörler: Mehmet Şeker- Fatih Yahya Ayaz- Yakup Kaya- Abdulvahab Alıc1, Necmeddin Erbakan Üniversitesi Yayınları, Konya 2017, s.59- 76.

8 Adana Ş.S. 44, img. 57, belge 105, 20 L 1202 (24 Temmuz 1788) tarihli düstûr-1 amel temessükü. 
tesellimi Ahmet Bey; 300'ünü ise Menemenci aşireti boybeyi Menemencioğlu II. Ahmet Bey toplayacak ve Şam'a gönderecekti ${ }^{9} .1790$ yılında gönderilen bir başka fermanda ise Adana mütesellimi Ahmet Bey'in 1.000 nefer piyade asker ile birlikte bir an önce gelip orduya katılması emir edilmekteydi ${ }^{10}$. Buradan anlamaktayız ki 1789 yılında başlanılan asker yazma işi tamamlanmamış ve Ahmet Bey 1790 yılı Ağustos'una kadar henüz Adana'dan dışarı çıkmamıştı.

\section{Adana Eyaletinden Deve veya Deve Bedeli İstenilmesi}

Bir savaş ortaya çıktığında devlet çoğu zaman Adana eyaletinden deve veya deve bahası istemekteydi. Akka Savunması'na yardım için Adana sancağından 150 mehar deve istenilmişti. Fermana rağmen sancaktan toplanabilen deve ise ancak 51 mehardı. Geriye kalan 99 mehar devenin çok acele gönderilmesi için defalarca emir gitmiş olmasına rağmen bu 99 mehar deve ortada yoktu. Beher mehar deve 150 kuruş hesabıyla 14.850 kuruşun hisse sahiplerinden toplanarak acele gönderilmesi için Adana mütesellimi olan Ahmet Bey’e, Adana kadısına ve diğer görevlilere ferman gönderilmişsiti ${ }^{11}$.

1797 yılında Vidinli Pasbanoğlu Osman Ağa isyan edip de Tırnovi kasabasını bastığı zaman Adana Mütesellimi Ahmet Bey'den Rumeli'deki bu isyanın bastırılması için 40 katar deve göndermesi istenilmişti ${ }^{12}$. Bu iş için İstanbul'dan Adana'ya gelen Mahmut isimli gedikli beher katarı 300 kuruştan develeri halktan satın alacak ve ayrıca her katar için 9'ar kuruş nafaka bahası ödeyecekti. Fermanın altında bu deve işi için farklı tarihlerde 4 ayrı ferman veya emir gönderilmiş olduğu da bildirilmekteydi. 1798 yılında gönderilen fermanda ise Adana sancağından istenilen deve miktarı 150 mehar olarak belirlenmişti ${ }^{13}$. Fermanın altındaki notta bu konuda acele edilmesini emr eden iki ayrı fermanın daha gönderilmiş olduğu bilgisi yer almaktadır. Bu açıklama devlet emirlerinin taşralarda yeteri kadar ciddiye alınmadığının bir kanıtı olarak değerlendirilebilir.

\section{Mütesellimlerin Mukataa Satın Alması ve İltizama Vermesi}

Ahmet Bey ile ilgili belgelerden büyük çoğunluğu mütesellimlik veya mukataa alımı veya iltizama verilmesi ile ilgilidir. Mukataa alım satımı veya iltizamı konusunda Ahmet Bey çoğu zaman kardeşi Mehmet Bey ile birlikte ihalelere katıllyordu. Yine çoğu ticaret işlemlerinde amcaları Hacı Ali Bey'in oğlu Mustafa Bey ile ortaklaşa hareket etmekteydiler. İstanbul'dan Kapudan-1 Derya, Tersane Emini gibi üst düzey görevlilerin de Adana'daki bu ihalelere katıldıklarını ve Adana'dan çeşitli mukataalar satın aldıklarını, yerli âyânlarla işbirliği içine girdiklerini, karşılıklı menfaat ilişkilerinin siyasi yansımalarını görebilmekteyiz ${ }^{14}$.

9 Adana Ş.S. 55, img. 59, sayfa 58, belge 79, 8 RA 1204 (26 Kasım 1789) tarihli hüküm.

10 Adana Ş.S. 55, img. 64, sayfa 125, belge 62, evâhir-i ZA 1204 / 2- 11 Ağustos 1790 tarihli ferman.

11 Adana Ş.S. 55, img. 68, sayfa 68, belge 50, 1 Ş 1204 / 16 Nisan 1790 tarihli ferman.

12 Adana Ş.S. 55, img. 14, sayfa 26, belge 205, 17 C 1212 / 7 Aralık 1797 tarihli ferman.

13 Adana Ş.S. 55, img. 29, sayfa 56-57, belge 158-159, 29 CA 1213 / 08 Kasım 1798 tarihli ferman.

14 TD. 114 (1572) Adana Mufassal Tahrir Defteri, v. 171aIII, 1729 tarihli belge.

Belgeler, Cilt: 37/Say1: 41; 39-210 
1791 yılında Adana ve Tevâbii İhtisab Mukataasını Karsîzâde Es-seyyid Ahmet Bey ve Es-seyyid Mehmet Bey emanet yoluyla ortaklaşa satın almışlardı. Bir kısım hissesi ise eski Tersane Emini Mehmet Emin Bey’in üzerinde idi. Karataş İskelesi vergilerinden ve diğer bazı vergilerden harc ve masraflar çıktıktan sonra 11.337 kuruş toplamışlardı. Bu paradan 4.251 kuruşun ise halen Ahmet Bey ve Mehmet Bey’in zimmetlerinde olduğu anlaşılmış ve derhal hazineye teslim edilmesi için bir hüküm gönderilmişti ${ }^{15}$. Hasanpaşa' dan sonra aile daha çok Hasanpaşazâdeler diye anıldı̆̆ı halde Hasan Paşa'nın torunlarına Karsîzâde (Karslıoğlu) diye hitap edilmiş olması dikkat çekmektedir.

\section{Yabancılara Zahire Satışı}

Kozanoğlu Deli Yusuf adlı kişiye ve bu kişiye yardım eden Farsak taifesine zahire verilmemesi yolunda Bozok sancağı mutasarrıfı Cabbarzade Mir Süleyman Bey'in daha önce boybeylerine göndermiş olduğu tembihlere rağmen bu kişiye buğday satışı yapılırsa cezaya uğratılacaklarına dair Adana mütesellimi Ahmet Bey ve Kara Hacılu, Bozdoğan, Karacalu gibi boy beylerine özel olarak ferman gönderilerek uyarılmalarına gerek duyulmuştu ${ }^{16}$. Belgede Kozanoğlu Yusuf'un bu zahireyi ne için ve hangi yetki ile topladığı açıklanmamıştır. Menemencioğlu Hacı Habib Bey zamanında Avrupa gemilerine zahire satılması konusunda Habib Bey yetkili kılınmış ve Menemenciler bu satıştan büyük paralar kazanmışlard1 ${ }^{17}$.

Burada Kozanoğlu denilmesine rağmen Deli Yusuf hakkında başkaca bir bilgi verilmediğinden bu kişinin Kozanoğullarından Topal Ağa'nın oğlu Yusuf Ağa olup olmadığı açık değildir. Çünkü onun için hiçbir kaynakta "Deli” sıfatının kullanıldığını görmedik. Ancak Kozan dağlarında yaşayan halkın çoğunluğu Varsak veya Farsak olarak bilindiğinden ${ }^{18}$ söz konusu Kozanoğlu Deli Yusuf diye tanıtılan kişinin Kozanoğlu Yusuf Ağa olması mümkün görünmektedir.

\section{Ayânların Eyalete Yeniçeri Serdarı Tayin Edilmesi}

Yeniçeriler taşra eyaletlerde görevlendirilmeye başlamalarından sonra yeniçeriler ve yeniçeri subaylarından bazı kişiler gittikleri bu bölgelerde yerleşip kaldılar. Adana âyân aileleri arasında bu şekilde yeniçeri kökenli aileler bulunmaktaydı. Hasanpaşazâdelerin dip dedeleri Karslı Hacı Hüseyin Ağa'nın da yeniçeri kökenli olduğuna dair ipuçları bulunmaktadır. 1792 tarihli Yeniçeri Ağası Ahmet Ăga'nın Adana kadısına gönderdiği mektupta Ahmet Bey’i Adana serdarı tayin etmiş olması belki de bu köken dolayısıyladır. Bu mektupta Ahmet Bey’e verilen görev, Adana' daki askerî unsurları zabt u rabta almak ve "haşerât" tabir edilen zararlı kişilerle mücadele ederek halkın huzur ve güvenliğini sağlamaktır. Kazâ dâhilinde bulunan bütün yerleşik ve misafir yeniçeriler, cebeciler, topçular, top arabacıları, acemi oğlanları ve kuloğulları üzerine serdar ve zabit tayin olunduğu bu belgede açıklanmaktaydı. Mirasçısı olmadan ölen

15 Adana Ş.S. 61, img. 5, s. 17, belge 22, 9 Ş 1205 / 13 Nisan 1791tarihli hükm-i şerîf.

16 Adana Ş.S. 57, img. 54, belge 136, evâ'il-i C 1206 / 26-01-04.02.1792 tarihli ferman.

17 Menemencioğlu Ahmed Bey, Menemencioğulları Tarihi, Yayına haz.: Yılmaz Kurt, Akçağ Yay., Ankara 1997, s. 58.

18 Ahmed Cevdet Paşa, Tezâkir, haz. Cavid Baysun, C III, 3. bs. Ankara 1991, s. 108- 109. 
yeniçerilerin ve askerî taifenin metrukâtları açık artırma ile satılıp elde edilen para defteriyle birlikte İstanbul'a Yeniçeri Ocağı'na gönderilecekti ${ }^{19}$. Bu türden eyalet serdarı tayinlerine şer 'iyye sicil kayıtlarında çok sık rastlanılmaktadır. Ama âyân ailesinden bir kişinin serdar tayin edilmesi birçok yönden incelenmeye değer bir konudur. 1793 yılında eski mütesellim Abdullahpaşazâde Ahmed Bey’in Yeniçeri Ağası Mustafa Ağa'nın mektubuyla ikinci defa Adana serdarlığına tayin edildiğini görmekteyiz. Her iki serdarlık atama mektubu tamamen aynı ifadelerle yazılmış kalıp yazılardandır ${ }^{20}$. Yine 1793 yılının Ekim ayında Ahmet Bey’i Adana mütesellimi olarak görmekteyiz ${ }^{21}$. Mütesellimlik ve serdarlık görevlerini birlikte yürüten Ahmet Bey, askerî beytülmâl işinin takibi için askerî sınıftan birilerini görevlendirmekteydi ${ }^{22}$.

\section{Cemâ'athâ-yı Yörügân-ı Adana ve Tarsus ve Sis Mukāta'ası ve Bozok Ayânı Mir Süleyman Bey}

Adana' da bulunan Cemâ'athâ-yı Yörügân-1 Adana ve Tarsus ve Sis Mukāta'ası büyük mukataalardan olup yıllık 9.869 kuruş devlete gelir sağlamaktaydı. Bu mukataayı malikâne olarak uhdelerine alan Ahmet ve Mehmet Bey ile amcaoğulları olan Mustafa Bey 1201-1206 (17861792) yılları arasında yaptıkları ödemelerin dışında 44.910 kuruş borçlu bulunmuşlardı. Bu borcun tahsili için İstanbul Başmuhasebe kaleminden Hafız Mehmet Emin özel görevli olarak Adana'ya geldi. Kendisine yardımcı olunması ve "bir an akdem ve bir saat mukaddem" bu paranın İstanbul'a ulaştırılması için Adana valisine, Adana kadısına ferman gönderilmişti²3.

"Bundan sonra kat'an te'hîr ve tevkîf olunmayarak" ifadesinden malikâne sahiplerinin çeşitli bahaneler öne sürerek borçlarını zamanında ödemedikleri ve borcun bu şekilde 44.910 kuruşa ulaştığı anlaşılmaktadır. 1793 tarihli bir başka fermanda ise söz konusu mukata'aya sahte ferman sureti ve beratla Yörügân-1 Bozdoğan Mukāta'asının mutasarrıfları olan Mustafa ve Sisli Kozanoğlu Yusuf'un ve Sis ve Çukurâbâd cânibinde bulunan bazı aşiretlerin müdahalede bulundukları görülmektedir ${ }^{24}$.

1794 yılı başında Hasanpaşazâdelerin bu borcu kapatmadığ 1 aksine borcun 59.768 kuruşa çıktığg görülmektedir. Borcun tahsili için Bozok âyânı Mir Süleyman Bey’e başvurulmuş ve onun desteğiyle 14.750 kuruş ancak toplanabilmişti. Oysaki hazine masrafları pek çoktu ve paraya şiddetle ihtiyaç duyulmaktaydı. Bu 9 senelik hesaptan arta kalan 59.768 kuruşun ilgili kişilerden "her ne şekilde olursa olsun" tahsil edilerek hazineye ulaştırılması için hüküm gönderilmişti25. 1795 y1lında mukataanın 10.077 kuruş malının "tamâmen ve kâmilen" 3 ortaktan tahsil edildiğini görmekteyiz ${ }^{26} .1210$ (1796) y1lında mukataa gelirlerinden 1201- 1202 y1llarına ait

19 Adana Ş.S. 63, img. 16, sayfa 53, belge 81, 01 ZA $1206 / 21.06 .1792$ tarihli yeniçeri ağası mektubu.

20 Adana Ş.S. 63, img. 32, sayfa 116, belge 143, 01 ZA1207 / 10.06.1793 tarihli yeniçeri ağası mektubu.

21 Adana Ş.S. 56, img. 30, sayfa 71, belge 8, 25 RA 1210 / 9 Ekim 1793 tarihli borç halâs senedi.

22 Adana Ş.S. 63, img. 7, sayfa 20, belge 22, 23 R $1208 / 28.11 .1793$

23 Adana Ş.S. 63, img. 23, sayfa 81, belge 111, 25 M 1207 / 12 Eylül 1792 tarihli ferman.

24 Adana Ş.S. 66, sayfa. img. 34, sayfa 21, belge 26, 26 C 1208 / 29 Ocak 1794 tarihli ferman; Adana Ş.S. 66, img. 34, sayfa 21, belge 26, 26 C 120829 Ocak 1794 tarihli ferman;

25 Adana Ş.S. 66, img. 13, sayfa 63, belge 78, 9 C 1208 / 12.01.1794 tarihli hüküm.

26 Adana Ş.S. 64, img. 60, sayfa 71, belge 160, 25 B 1210 / 11 Ağustos 1795 tarihli tahvil.

Belgeler, Cilt: 37/Say1: 41; 39-210 
44.361 kuruşun acilen İstanbul'a gönderilmesi ve hazineye teslim edilmesi için Adana kadısı ve Bozok sancağı mutasarrıfı Cabbarzâde Mir Süleyman Bey’e emr-i şerif gönderilmişti²7. Istabl-1 âmire masrafları için mukataa gelirlerinden gönderilmesi istenilen 4.470 kuruş zamanında gönderilmeyince yine Cabbarzâde Süleyman'dan yardım istenilecekti ${ }^{28}$. Sadrazamlık Mektubî Kalemi halifelerinden Mehmet Emin Efendi bu mukataa gelirini toplamak için özel görevli olarak Adana’ya gitmiş döndüğünde verdiği uzun raporundan sonra istenilen paranın yeniçeri mevacibinin dağıtılmasından önce yetiştirilebilmesi için 1796 yılı Ekim ayında Cabbârzâde Süleyman Bey’e emir gönderilmesi gerekli görülmüştü ${ }^{29}$. Menemenci aşiretinin devlete olan 10.000 kuruş vergi borcunu toplamak için özel olarak gönderilen çukadar Mehmet Ağa ancak 5.000 kuruş toplayabilecektir ${ }^{30}$.

Cemaatha-i Yörügan-1 Adana ve Tarsus ve Sis Mukāta'ası'nın hesabını kapatmak bir türlü mümkün olmuyordu. 1201 senesinden 1210 senesine gelinceye kadar mukataanın 29.712 kuruş vergi borcu birikmişti. Devlet bu parayı alabilmek için taviz vermek zorunda kalacak ve senede 5.000 kuruş taksite bağlanacak ama mukataanın değişmez üçlüsü görevlerine devam edeceklerdi. İstanbul, bu durumu padişah iradesine ve kendisinin taahhüdüne aykırı bulmuş, mukataanın kendilerinden alınarak isteklisine satılması ve zimmetleri olan meblağın def ${ }^{\star}$ aten tazmini gerekli olmuş ise de yine taviz verilerek "bu def a tenbîh ile iktifâ" olunmasını yeterli bulunmuştu ${ }^{31}$.

\section{Eski Müftüye ve Yeni Serdara Eman Hücceti Verilmesi}

1793 tarihli belge, eski mütesellim Ahmet Bey ve diğer ağaların eski müftü Eş-şeyh El-hâcc Mehmet Efendi'ye verdikleri ilginç bir sulh hüccetidir. İlginçliği normal uygulamada eski bir mütesellimin eski bir müftüye böyle teminatı havi bir hüccet vermesi usul olmadığ $\breve{1}_{1}$ halde buna gerek duyulmuş olmasıdır. Hüccet eski müftüye verilmiş olmakla birlikte içeriğinde müftü hakkında zımnen bir suçlama ve hakaret sezilmektedir. Hüccet verenler "cümle 'ulemâ ve sulehâ e'imme ve hutebâ ve müderrisîn-i kirâm-1 zevi'l-ihtirâm" diye başlamakta, asker ve ulemâ bütün Adana vücuhunun eski müftüye bir "eman hücceti" verdikleri anlaşılmaktadır. Ancak "kimsenin malına ve canına suikast etmedikçe" biz de onun canına ve malına tecavüz etmeyeceğiz şeklindeki bir teminat hücceti garip olduğu gibi "evhâm-1 hayâlâta teba 'iyyet ve vesveseye zâhib" olmak iddiası da emekli bir müftü için hakaret taşıyan ifadelerdir. Eski müftü Mehmet Efendi'nin yerine kimin müftü olduğu bildirilmemişse de Ahmet Bey'in babasının amcası oğlu olan Adana Müftüsü İshak Efendi'nin bu işin içinde olması büyük bir ihtimal olarak görünmektedir ${ }^{32}$.

Adana Ş.S. 56, img. 16, sayfa 31, belge 43, 28 L 1210 / 06 Mayıs 1796 tarihli emr-i şerif.

Adana Ş.S. 56, img. 16, sayfa 57, belge 44, 17 L 1210/ 25 Mayıs 1796 tarihli emr-i şerîf.

BOA, C. ML 781/31892, 6 R 1211 / 09 Ekim 1796 tarihli telhis.

BOA, C. Dahiliye 17063-B, 25 Receb 1211/ 24 Ocak 1797 tarihli Bozok Mutasarrıfı Süleyman Bey’in arîzas1.

Adana Ş.S. 55, img. 10, sayfa 18, belge 215, 18 S 1212 / 12 Ağustos 1797 tarihli ferman sureti.

Adana Ş.S. 56, img. 23, sayfa 57, belge 30, 11 Ş $1211 / 13$ Şubat 1793 tarihli hüccet. 
1796 y1lında Adana Mütesellimi Ahmet Bey’in aynı yolda bir teminat verdiğini görmekteyiz. $\mathrm{Bu}$ sefer kendisine teminat verilen kişi Adana'nın eski ayânlarından olup Adana serdarlığı görevine atanan Mustafa Ağa ile ilgilidir. Saray serturnacılarından olan Mustafa Ağa için Ahmet Bey'in "ez kadîm 'eban ve an ceddin bi'l-cümle hizmetimizde sadâkat ve istikāmet üzere olub” şeklindeki ifadesinden Mustafa Ağa’nın Hasanpaşazadelerle ilgili bir kişi olduğu anlaş1lıyor. Bu anlaşmaya kefil olan kişiler arasında o sırada fiilen Adana Müftülüğü görevinde bulunan aynı aileden İshak Efendi'nin bulunması da aile içerisinde çıkan iktidar çekişmesinin bu şekilde çözüme ulaştırıldığı şeklinde yorumlanabilir³3.

26.10.1794 tarihli sulh hüccetinde adı geçen 3 mukata a işletmecisi babalarının amcaoğlu olan İshak Efendi'deki 4.248 kuruşluk alacaklarından 1.750 kuruş alarak vazgeçtiklerini ve hiçbir davaları kalmadığını bildiriyorlard ${ }^{34}$. 26.09.1794 tarihli 79 mumaralı belge de tam olarak aynı konuyla ilgili adıgeçen 3 kişi tarafından verilmiş bir ibranâmedir ${ }^{35}$.

\section{Vakıf Yönetimine ve Vakıf Mallarına El Atılması}

1795 yılında Adana'nın en büyük vakfı olan Ramazanoğulları Vakfı "Sadrazam nezâretinde âsûde evkāftan olup Sadrazam mektûbî halifelerinden Seyyid Halil Mahir mütevelli kaymakamı olarak tayin edilmişti. Vakfın gelir kaynaklarından Adana' da bulunan Yeni Han'ın 12041208 seneleri kira gelirinden toplam 1.600 kuruş Yeğenzâde Seyyid Mehmed Said ve Hac1 (Ali) Beyzâde Mustafa Bey zimmetinde bulunuyordu. Yine vakfa ait Eğlemez Hanı'nın 1208 senesi kira gelirinden Abdullahpaşazâde Ahmet Bey ve Mehmet Bey zimmetlerinde 150 kuruş olmak üzere çeşitli vakıf gelirlerinden değişik kimselerde birikmiş olan vakıf alacaklarının ödenmediği görülmüştü. Sadrazam çukadarlarından Abdullah'ın isteği üzerine bu vakıf alacaklarının tahsili için İstanbul'dan ferman gönderilmiştit ${ }^{36}$.

\section{Karcı Mehmet Ağa'nın İdamı ve Diğer Olaylar}

1796 yılında idam edilen Adana mütesellimi Karcı Mehmet Ağa’nın malları usül gereği müsadere edilmiş ancak Adana Valisi Yusuf Paşa, Karcı Mehmet'in eşinin mallarına da el uzatınca görevden alınmış yerine Mehmet Paşa atanmış ve bu görev değişikliği sırasında Hasanpaşazâde Ahmet Bey mütesellimlik makamına getirilmişti. Karcı Mehmet Ağa'nın 1208 ve 1209 y1llarına ait Adana cizyesi tahsilâtından 27.745,5 kuruş zimmetinin tahsili için İstanbul'dan gelen İbrahim ve Abdullah marifetiyle malları müzayedeye çıkarılmışt1 ${ }^{37}$.

XVIII. yüzyıl sonlarında Anadolu'nun bazı bölgelerinde ve Çukurova' da konar-göçer aşiretler tahrire tabi tutularak asker ve vergi açı̆̆ı kapatılmaya çalışıldığı sırada Tekeli aşireti de tahrir

33 Adana Ş.S. 56, img. 31, sayfa 73, belge 4, 21 Ramazan 1210 / 30 Mart 1796 tarihli hüccet.

34 Adana Ş.S. 62, img. 4, sayfa 32, belge 77-78, 1 R 1209 / 26.10 .1794 tarihli hüccet.

35 Adana Ş.S. 62, img. 4, sayfa 32, belge 79, 1 RA 1209 / 26.09.1794 tarihli ibranâme.

36 Adana Ş.S. 66, img. 12, sayfa 65, belge 79, 11-20 C 1209 / 03-11 Ocak 1795 tarihli ferman sureti.

37 Adana Ş.S. 56, img. 12, sayfa 22-23, belge 53, 14 N 1210 / 23 Mart 1796 tarihli hüküm.

Belgeler, Cilt: 37/Say1: 41; 39-210 
edilmişti ${ }^{38}$. Tarsus taraflarında yaşayan Tekeli aşireti reisi Tekeli Mir Ali Bey’den 500 nefer asker ile Mısır tarafında bulunan orduya katılması emredilmişti. Ancak bu askerin zamanında toplanıp, techiz edilip gönderilmesinden ümit kesilmiş olmalı ki her asker için 50 kuruş olmak üzere 25.000 kuruş bedel verilmesi istenilmiş sonra bundan da indirime gidilerek 15.000 kuruş gönderilmesinin yeterli olacağ 1 Adana mütesellimi Ahmet Bey’e ve diğer görevlilere bildirilmişti ${ }^{39}$.

\section{Mütesellimlik Yetkisi}

Ahmet Bey, 1793 yılından 1812 yılına kadar birçok defa Adana mütesellimi olarak atanmıştır. Bazı mütesellimlik beratları İstanbul'dan gelirken bazılarının Adana valisinin veya yardımcısının başvurusunun tasdiki ile gerçekleşmektedir. 1796 tarihli mütesellimlik emri Rumeli beylerbeyi olup İsmail Muhafızlığı ile görevlendirilmiş olan ve kendisine ek olarak Adana eyaleti valiliği de verilen Mehmet Paşa'nın vekili olarak gerçekleşmişti ${ }^{40}$.

\section{Menzil İdaresi ve Adana'da Çekirge İstilâsı}

Ahmet Bey'in mütesellimliği 1796 Nisan ayında Yusuf Paşa'nın Adana Beylerbeyiliğine atanması ile sona ermişti. Ama 1796 yılı başında halkın en büyük sıkıntısı 5 seneden beri devam eden çekirge istilası idi. Çekirge istilası yanında Adana eyaletinin hiç bitmeyen şikâyetleri de devam ediyordu: Aşiretler arasında ortaya çıkan karışıklıklar, halkın komşu eyaletlere kaçmasına yol açmıştı. Bu yüzden de 12.000 haneden oluşan Adana kazâsının nüfusu 300 haneye kadar inmişti. Hac ve ticaret yolu üzerinde olan eyaletteki menzillerin idaresi imkânsız hale gelmiş olduğundan Adana pamuk vergisi gelirlerinden 10.000 kuruşun bu işe verilmesine izin istenilmekteydi. Bu istek Adana paşasının kaimesi, kadı efendinin arzı, halkın mahzarı ve İstanbul'a bizzat giden halkın sözlü şikâyetleriyle -reddedilmesi nerede ise imkânsız bir mükemmellikte- iletilmişti. Ancak pamuk vergisi Îrâd-1 Cedîd Hazînesi'ne ait olunca buna dokunulamamış ve başka yerden verilmesi gerekmişti. Adana menzillerinde toplam 11 beygir bulunmakta ve yıllık masrafları olan 797,5 kuruş Adana avarızından sağlanmaktaydı. Sonuçta devlet 10.000 kuruş yerine 5.000 kuruş verilmesine ve bunun da cizye malından ödenmesine karar vermişti ${ }^{41}$.

\section{Adana Cizyesi}

Daha önce eski Adana mütesellimi Karcı Mehmet Ăğa'ya ihale edilmiş olan Adana cizyesinin cibayeti işi Karcı Mehmet’in idamından sonra 1796 yılı Nisan ayında Adana mütesellimi Ab-

38 XVIII. yüzyılda gerçekleştirilen bu tahrirlere ilişkin geniş bir değerlendirme için bk. Yılmaz Kurt, "TKGM Arşiv Belgelerine Göre Lale Devri Tahrirleri”, 2. Uluslararası Osmanlı Coğrafyası Arşiv Kongresi, C II, Tapu ve Kadastro Genel Müdürlüğü Arşiv Dairesi Başkanlığı Yayınları, Ankara 2019, s. 1221- 1230.

39 Adana Ş. S. 57, img. 10, sayfa 13, belge 35, 19 N 1210 / 28 Mart 1796 tarihli hüküm.

40 BOA, C. DH. 11/533, 3 L 1210 / 11 Nisan 1796 tarihli İsmail mufafızı ve Adana valisi Mehmet Paşa'nın kapu kethüdasının arzı; Adana Ş.S. 55, img. 78, sayfa 153 belge 13, Evail L 1211 / 30 Mart-8 Nisan 1797 tarihli mütesellimlik ferman1.

41 BOA, C. ML 462/18784-1, 15 L 1210 / 23 Nisan 1796 tarihli hüküm. 
dullahpaşazâde Ahmet Bey’e 12.000 kuruş karşılığında ihale olunmuştu ${ }^{42}$. Uygulamada cizye 13.000 kuruş olarak kesinleşmişti. Ahmet Bey'e verilen 06 Mayıs 1796 tarihli cizye beratında ise Hanefî̀ mezhebi görüşleri doğrultusunda 443 a' lâ ( her birinden 11 esedî kuruş); 3.588 evsat ( her birinden 5,5 esedî kuruş) ve 704 ednâ (2,5 kuruş ve 1 rub') olmak üzere 4.735 cizye evrakı teslim edilmiş ve görev alanı ile yetkisi açık açık bildirilmiştił3. Maliye Kaleminden yazılan 07 Mayıs tarihli belgede yine Karcizâde Mehmet Ă̆a'dan intikal eden bu cizye cibayeti işinin "Adana eyaletinin perişanlığı hasebiyle cizyesi dahi çürük ve bî-hâsıl olduğundan, el-yevm buyuruldusu derdest olup kimesne tâlib olmadığından" 500 kuruş zam yapılarak maktû' olarak Ahmet Bey’e verilmesinin uygun olacağı bildirilmekteydi44 ${ }^{4}$ Cizye cibâyeti gibi kârlı bir işe hiç kimsenin talip olmaması Câbi Tarihi'nde bizzat Hasanpaşazâde Ahmet Bey hakkında öne sürülen iddialarla birlikte düşünüldüğünde oldukça şüpheli bir durumdur ${ }^{45}$. Mukataa ihalelerine katılmak için bölgeye gelen yabancı kişilerin nasıl korkutulup kaçırıldı̆̆ını ve devlet ihalelerine katılmaktan men edildiğini doğru kabul edersek bu cizye meselesinin dahi aynı şekilde geliştiğini düşünebiliriz. 1797 yılı Mayıs ayında Adana'nın cizye malından 1.500 kuruşun mevacibe ayrılmış olduğundan dolayı İstanbul'a gönderilmesi için ferman yayınlanmış ve mübaşir tayin olunan El-hâcc Mehmet ile gönderilmişti4t

\section{Zatî Mühürlerin Kayıp Olması ve Mukataa Ücretleri}

1796 yılı Haziran ayında Adana mütesellimi Ahmet Bey’in yardımcısı (kethüda) Halil Ağa'nın ve Hasanpaşazâde Mustafa Bey’in mühürleri kayıp olmuştu. Halil Ağa'nın kendi ismine mührü 4 Zilhicce 1210/ 10 Haziran 1796 tarihinde kayıp olmuştu. Halil Ağa dikkatsiz bir kimse olmalı ki kendi ismine bir gümüş ve bir bakır mührünü de birkaç ay sonra 8 Rebiülahir 1211/ 11 Ekim 1796 tarihinde kayıp etmişti. Mukataa ihalelerinin değişmez ismi Hasanpaşazâde Mustafa Bey ise yine aynı y1l 27 Rebiülahir 1211/ 30 Ekim 1796 tarihinde mührünü kayıp etmiş ve herhangi bir mühür sahtekârlığını önlemek için hemen kadı efendiye gelerek mühürlerini kayıp ettiklerini kadı siciline işletmişler ve böylece sorumluluktan kurtulmuşlard ${ }^{47}$. Bu mühür kaybından sonra ortaya çıkan herhangi bir şikâyet kayıtlarda görülmemiş olmakla birlikte aynı yıl içerisinde 3 defa mühür kaybının deftere yansıması dikkat çekmektedir.

42 BOA, C. ML 462/18784-2, 16 L 1210 / 24 Nisan 1796 tarihli takrir. Bu takrire dayalı olarak hazırlanan emr-i şerifte görev ve yetki ayrıntılı şekilde aktarılmıştı. Emr-i şerifin aslına arşiv kayıtları içerisinde ulaşılamamış, sureti Adana sicillerinde yer almıştır: Adana Ş.S. 56, img. 36, sayfa 67, belge 14, 5 Mayıs 1796 tarihli belge.

43 Adana Ş.S. 56, img. 29, sayfa 68, belge 13, 6 May1s 1796 tarihli cizye beratı sureti.

44 BOA, C. ML 462/18784-2, 16 L 1210 / 24 Nisan 1796 tarihli cizye gelirinin maktu' olarak Ahmet Bey’e verilmesinin uygun olacağına dair maliyeden verilen arz tezkiresi.

45 Câbî Tarihi, C II, s. 896- 897: "Zeâmet, timar ve mukâta'a sahiplerine birer miktar meblăg irsaliyle bu dirlikleri zabt eder, yanlışlıkla bir iltizâmcı alıp gitse adı geçeni dönüşte helâk eder ve "mahallinde zulm eyledi" diyerek ahaliyi idam ederdi".

46 Adana Ş.S. 55, img. 11, sayfa 20, belge 213, 14 ZA 1211 / 11 Mayıs 1797 tarihli ferman sureti; Adana Ş.S. 55, img. 19, sayfa 36, belge 193, 5 ZA 1212 / 21 Nisan 1798 tarihli ferman sureti.

47 Adana Ş.S. 56, img. 01, sayfa 01, belge 78-b, 04 Z 1210 / 10 Haziran 1796 tarihli kayıt altında diğer mühür kayıpları kayıt edilmişti.

Belgeler, Cilt: 37/Sayı: 41; 39-210 
1797 yılında devlet, Adana'da bulunan bütün mukataaların bir defterini çıkartarak borçlarını tespit ettirmişti. Mukataa borçlarının tahsili için ferman gönderildiğinde mukataa işletmecileri “Adana'nın perişanlığından” dem vurarak borçlarını ödemekten kaçınıyorlardı. Bu şekilde biriken devlet alacaklarının toplamı 114.431 kuruşa ulaşınca devlet Şıkk-1 evvel defterdarlığı memurlarından Hacı Mehmet'i özel görevli olarak tayin edip göndermişti. Adana'nın vergi vermemek konusundaki tutumunu bilindiğinden olmalı ki Hacı Mehmet'in ardından ikinci bir ferman ile mübaşir El-hâcc Mustafa işin acele bitirilmesi için koşturmuştu ${ }^{48}$. Bu özel görevlilerin yol harcırahları da toplanacak miktara eklenerek yine halktan alınmakta olduğundan bu şekilde özel görevli (mübâşir) gönderilerek halka zulm edilmemesi yolunda padişahın hatt-1 hümayunu bulunmaktadır.

Devlet alacaklarının bazen doğrudan belirli yerlere gönderilmesi de ayrı bir istismar ve sömürü konusu olduğu için bizzat padişah tarafindan eleştiri konusu yapılmakta ve daha az görevli gönderilmesi de istenilebilmekteydi. Cemaatha-i Yörügân-1 Adana Mukataası'nın 1210/ 1796 y1lı gelirinden 2.500 kuruş Rumeli'de Akkirman Kalesi muhafızlarının masrafları için gönderilmişti ${ }^{49}$.

1798 yılında Adana ve Sis (Kozan) İspençe Mukataasının işletmecisi olan Divân-1 hümâyûn görevlilerinden Osman, mukataayı bir yıllığına Hüseyin'e iltizama vermişti. Hüseyin, Adana sakinlerinden olmasına rağmen Topkapı Sarayı gediklilerinden birisi olarak tanıtılmaktaydı. Mukataa sahibinin de, iltizama alan kişinin de İstanbul bağlantılı olması dikkat çekmektedir ${ }^{50}$.

\section{Yol Güvenliği ve Menzilhaneler}

Adana eyaletinin en büyük sorunlarından birisi de yol güvenliğinin sağlanamayışı idi. Hac kafileleri, tüccâr kervanları soyulduğu gibi zaman zaman devlet görevlileri, hatta kadılar bile soyulmaktaydı. 1798 yılında Sayda Valisi Cezzar Ahmet Paşa tarafından İstanbul'a gönderilmekte olan tatar (ulak) Ceyhan yakınlarındaki Kurt Kulağı Menzili’nden çıkmış, Ilıcak Beli denilen bölgede eşkıya saldırısına uğramıştı. Saldırı sırasında 3 beygir ve eşyaları gasp edildiği gibi tatar da katl edilmişti. Adana mütesellimi Ahmet Bey’e gönderilen fermanda tatarın katillerinin bulunması ve yol güvenliğinin de sağlanması emir edilmekteydi ${ }^{51}$.

1798 yılında Adana valisi Ataullah Paşa'nın aşiretlerden alacağ 10.000 kuruş için Adana mütesellimi Ahmet Bey ve aşiret ileri gelenleri kefil olmuşlar ve 5.000 kuruşu için 11 gün vadeli; diğer 5.000 kuruşu için ise 91 gün vadeli iki senet verilmişti. Mallarıyla ve canlarıyla kefil olanlar arasında sadece Menemenci aşireti boybeyisi olan II. Ahmet Bey’in aşireti belirtilmiş diğerlerinin hangi aşiret adına imza koydukları açıklanmamıştır ${ }^{52}$. 


\section{Ahmet Bey'in Diplomasi Zaferi ve Yeniden Mütesellim Olması}

1798 yılında Ahmet Bey’in yerine Adana mütesellimi olarak II. Hacı Ali Bey’in oğlu olup birçok mukataa işlemlerinde Ahmet Bey’in ortağı bulunan Mustafa Bey tayin olunmuştu. Ancak yıllarca mütesellim olarak görev yapmış olan Ahmet Bey, kendisi dururken yerine amcasının oğlunun tayin edilmesine razı olmayarak hemen şikâyet mekanizmasını harekete geçirmişti: Adana gibi aşiretlerle dolu bir eyalette yaşı çok küçük olan Mustafa Bey'in aşiretlerin halka zarar vermesini önlemeye gücü yetmeyecekti. Kaldı ki bütün halk kendisinden son derece hoşnut olduğu halde böyle bir tayin gereksizdi ${ }^{53}$. Osmanlı diplomatikasında örnek olarak kullanılabilecek bu belge Adana ve Tarsus kadılarının arzları, Adana'nın eski ve yeni müftüsünün ortak arzları ve halkın mahzarları üzerine kaleme alınmıştı. Belgenin üzerine yazılan emirden Ahmet Bey'in arzusuna ulaştığı anlaşılmaktadır. Aynı aileden Hüseyin Efendi’nin ve oğlu İshak Efendi'nin Adana müftülüğü yapmış oldukları hatırlanacak olursa bu müftü desteği daha iyi anlaşılacaktır.

\section{Sonuç}

Adana eyaletinde devlet yönetiminin ne şekilde işlediği, ekonomi çarklarının ne şekilde döndüğü, âyânların halk ve devlet üzerindeki gücünü gösteren yukarıda değerlendirmesini yaptığımız bu arşiv belgeleri yaklaşık 10 yıllık (1788-1798) bir zaman dilimini kapsamaktadır. Halkın ekonomik durumunun kötülüğü bazen aşiretler arasındaki çatışmalara, bazen çekirge istilasına bağlansa da sonuçta hep merkezin gücünün azaltılması talepleri öne çıkıyordu. Bu talepler kısa bir süre sonra "vali besleyecek gücümüz yoktur” şeklinde dile getirilmeye başlanilacaktır.

Rumeli' de bulunan kalelerin korunması için valilerin muhafız olarak görevlendirilmeleri Adana'na çoğu zaman vali vekili olarak görev yapan mütesellimlerin öne çıkmasına sebep olmuştur. 1750'lerden başlayarak güçlenen mahallî âyânlar valilerin ayağını kaydırarak bölgede etkinliklerini ve servetlerini artırmışlardı.

Belgelerin değerlendirilmesinden çıkan ortak sonuç ise merkezi otoritenin taşralardaki etkinliğinin acınacak bir duruma düşmüş olmasıdır. Bunun görünürdeki sebebi Napolyon'un Misır Seferi olsa da çöküşün çok daha önceden başlamış olduğunu söylemek mümkündür.

Adana mütesellimi Hasanpaşazâde Ahmet Bey, 1798 tarihinden sonra da Adana'nın yönetiminde etki olmaya devam edecek 1812 yılında ölünceye kadar Adana'nın en etkin âyânı olarak kalacak ve bu gücü kendisinden sonra kardeşi Mehmet Bey kullanmaya başlayacaktır. Burada yer alan belgeler özelde bir âyân ailesine ait olsa da devlet emirlerinin taşralarda ne şekilde uygulandığını en açık örnekleri ile göstermesi bakımından da çok önemlidir. 


\section{KAYNAKLAR}

\section{Arşiv Kaynakları}

BOA, Cevdet Dahiliye, 17063-B, 25 Receb 1211/ 24 Ocak 1797 tarihli Bozok Mutasarrıfi Süleyman Bey'in arîzası.

BOA, Cevdet Dahiliye, 11/533.

BOA, Cevdet Dahiliye, 25/1237.

BOA, Cevdet Maliye, 781/31892, 6 R 1211 / 09 Ekim 1796 tarihli telhis.

BOA, Cevdet Maliye, 462/18784-1.

BOA, Cevdet Maliye, 462/18784-2.

BOA, Cevdet Maliye, 462/18784-2.

TD. 114 (1572) Adana Mufassal Tahrir Defteri.

\section{Araştırma ve İnceleme Eserler}

Ahmed Cevdet Paşa, Tezâkir, haz. Cavid Baysun, C III, 3. basım, Ankara 1991.

Câbî Ömer Efendi, Câbî Târihi, C II, haz. Mehmet Ali Beyhan, Türk Tarih Kurumu Yayınları, Ankara 2006.

Ener, Kasım, Tarih Boyunca Adana Ovasına (Çukurova 'ya) Bir Bakış, 7. basım, İstanbul 1986.

Kurt, Y1lmaz, “Çukurova' da A ‘yânlık Mücâdelesi: Hasanpaşazâdeler”, XV. Türk Tarih Kongresi Kongreye Sunulan Bildiriler, 20-24 Eylül 2010 Ankara, 4. Cilt-1. Kısım, Osmanlı Tarihi, Türk Tarih Kurumu Yayınları, Ankara 2010, s. 1259-1278.

Kurt, Yılmaz- Ünlü, Ertan, “Çukurova Âyânları I: Hasanpaşazâdeler ile İlgili Arşiv Belgeleri I”, Belgeler, C XXXIII/S. 37 (2012), Türk Tarih Kurumu Yayınları, Ankara 2014, s. 57-116.

Kurt, Yılmaz- Ünlü, Ertan, “Çukurova Âyânları II: Hasanpaşazâdeler (Karslıâdeler) ile İlgili Arşiv Belgeleri II”, Belgeler, C XXXIV/S. 38 (2013), Türk Tarih Kurumu Yayınları, Ankara 2016, s. 17- 86.

Kurt, Yılmaz, "Ramazanoğulları'nın Sonu”, Ramazanoğulları Beyliği, Uluslararası Orta Anadolu ve Akdeniz Beylikleri Tarihi, Kültürü ve Medeniyeti Sempozyumu-III, Editörler: Mehmet Şeker- Fatih Yahya Ayaz- Yakup Kaya- Abdulvahab Alıc1, Necmeddin Erbakan Üniversitesi Yayınları, Konya 2017, s. 59- 76. 
Kurt, Yılmaz, "TKGM Arşiv Belgelerine Göre Lale Devri Tahrirleri”, 2. Uluslararası Osmanlı Coğrafyası Arşiv Kongresi, C II, Tapu ve Kadastro Genel Müdürlüğü Arşiv Dairesi Başkanlığı Yayınları, Ankara 2019, s. 1221- 1230.

Menemencioğlu Ahmed Bey, Menemencioğulları Tarihi, Yayına hazırlayan: Yılmaz Kurt, Akçă̆ Yayınları, Ankara 1997. 
Sira No : 1

Belge No : Adana Ş.S. 44, img. 57, belge 105

Tarih $\quad: 20$ L $1202 / 24.07 .1788$

Konu : Ramazanoğlu evkâfından Yeni Han yakınında bulunan dükkânların mutasarrıfı Çelebi Ağa'nın vefat etmesiyle dükkânların 1787-88 senesi için Ser-turnayî Seyyid Halil Ağa'ya ve amcazâdesi Mustafa Ağa’ya ve Hasanpaşazâdelerden Ahmed Bey ve Mehmed Bey'e kiraya verilmesine dair.

Vech-i tahrîr-i hurûf budur ki:

Ceddimiz merhûm Ramazanoğlu evkâfından sûkda vâk1' Yeni Hân kurbunda bir bâb dükkâna mutasarrıf ve Unbazarı'nda vâk1' bir kahve ve bir bâb bakkâl dükkânı ve bir bâb uncu dükkânı ve bir helvacı dükkânına mutasarrıf ve Yeni Han derûnunda vâkı' ketenci örügüne mutasarrıf ve cânbâzlar içinde vâk1 ' bir bâb berber dükkânı ve eskiciler arasında bir bâb ve kavukcular içinde bir bâb bazergânlar içinde bir bâb dükkân ve kebapçılar başında bir bâb ve duhâncı dükkânına işbu mezkûr dükkânlara mutasarrıf olan Çelebi Ağa fevt olub dükkân-1 mezkûrlar mahlûl olmağla bin iki yüz iki senesi Şevvâl-i şerîfinin yirmi(nci) gününden senesi gâyetine değin îcâr ve mu'accelesiyle devletlü necâbetlü Ser-turna-yî Seyyid Halil Ağa'ya ve birâderzâdesi Mustafa Ağa'ya ve Hasanpaşazâdeler Ahmed Bey ve Mehmed Bey'e 'ale'l-iştirâk îcâra merkûmlar dahi istîcâr kabûl eylemeleriyle yedlerine düstûr-1 'amel temessükü verilmişdir. Gerekdir ki tarafımızdan ve taraf-ı âherden mümâna'at etmeye.

El-fakîr Mîr Süleyman mütevellî-i vakf-1 mezbûr. 
Sira No : 2

Belge No : Adana Ş.S. 55, img. 59, sayfa 116, belge 79

Tarih $\quad$ : 8 RA 1204 / 26 Kasim 1789

Konu : Adana Mütesellimi Ahmed Bey’in 500 nefer ve Melemencizâde Ahmed Bey’in 300 nefer olmak üzere toplam 800 mîrîlü piyâde askeri yazarak orduya göndermeleri hakkında.

Düstûr-1 mükerrem müşîr-i mufahham nizâmü'l-'âlem müdebbirü'l-umûri'l-cumhûr bi'l-fikri's-sâkıb mütemmimü mehâmi'l-enâm bi'r-re'yi's-sâ'ib mümehhidü bünyâni'd-devlet ve'l-ikbâl müşeyyidü erkâni's-sa'âdet ve'l-iclâl el-mahfûfu bi-sunûfi 'avâtıfi'l-meliki'l-a 'lâ hâlen Adana vâlisi vezîrim Hüseyin Paşa edâme Allâhu ta'âlâ iclâlehu tevkî'-i refî'- hümâyûn vâsıl olıcak ma'lûm ola ki:

Adana Mütesellimi Dergâh-1 mu'allâm kapucubaşılarından Ahmed Bey dâme mecdühu ma'rifetiyle beş yüz nefer ve Melemencizâde Ahmed Bey zîde mecdühu ma'rifetiyle üç yüz nefer mîrîlü piyâde askeri tahrîr ve münâsib sergerde ta 'yîn ile işbu mâh-1 Rebi'ü'l-evvelin evâhirinde Şam-1 şerîfde ordu-yı hümâyûnuma irsâl ve tesyîre müsâra'at eylemeleri bâbında me'mûriyetlerini hâvî başka başka ve ber mûceb-i sudûr îcâb iden mîrîleri bu def'a Der-'aliyyemden Sadr-1 a zamım çukadârlarından ( ) Ağa zîde kadrühunun ${ }^{54}$ Ordu-yı hümâyûnuma getüreceği ikiyüzelli kise akçadan ifrâz ve taraflarına teslîm olunmak üzere çukadâr-1 merkûma hitâben başka üç kıt'a evâmir-i şerîfim 1sdâr ve irsâl olunmağla imdi sen ki vezîr-i müşârün ileyhsin mûmâ ileyhümânın tahrîr idecekleri piyâde 'askeri işe yarar güzîde ve cenk-âver ve harb ü darbe kādir yiğitlerden olarak tamâmca tahrîr ve münâsib sergerde ta'yîn ile mâh-1 mezbûr evâhirinde ordu-yı hümâyûnuma irişdirilmesi husûsuna sen dahi nezâret ve ikdâm-1 tâmm eylemen fermânım olmağın hâsseten işbu emr-i celîlü’l-kadrım 1sdâr ve sadr-1 a'zamım tatarlarından Ali zîde kadruhu ile irsâl olunmuşdur. İmdi vusûlünde ber minvâl-i muharrer mîr-i mûmâ ileyhümânın mîrîlü piyâde olarak tahrîr idecekleri sâlifü’z-zikr sekiz yüz nefer piyâde 'asker işe yarar ve güzîde ve cenk-âver ve harb (ü) dârbe kādir yiğitlerden olarak icâleten ve müsâra'aten tamâmca tahrîr ve münâsib sergerde ta'yîn ile mâh-1 mezbûr evâhirinde Şam-1 şerîfde ordu-y1 hümâyûnuma irişdirilmesini mîr-i mûmâ ileyhümâya ifâde ve tefehhüm ve sen dahi bu husûsa nezâret-i tâmm ve dikkat iderek fermûde-i 'aliyyem üzere tanzîme bezl-i cell-i himmet ve sarf-1 küll-i miknet eylemen bâbında fermân-1 'âlîşânım sâdır olmuşdur. Buyurdum ki:

Hükm-i şerîfimle ( ) vardıkda bu bâbda vech-i meşrûh üzere şeref-yâfte-i sudûr olan işbu emr-i şerîf-i 'âlîşânımın mazmûnu üzere 'âmil olasız. 'Alâmet-i şerîfe i'timâd kılasız. Tahrîren fî‘l-yevmi’s-sâmin şehr-i Rebi'ü’l-evvel sene erba'a ve mie'teyn ve elf.

Be-yurd-1 sahrâ-yı Ma'den. 
Sira No : 3

Belge No : Adana Ş.S. 55, img. 68-69, sayfa 134-135, belge 50

Tarih : : 1 Ş $1204 / 16$ Nisan 1790

Konu : Adana sancağından toplanacak 150 mehar deveden arta kalan 99 mehar deve bedeli olan 4858 guruşun ilgili kazalardan tahsil edilerek ordu-yı hümayûn hazînesine yollanmasına dair fermân.

İftihârü'l-emâcid ve'l-ekârim câmi'u'l-mehâmid ve'l-mekârim el-muhtassu bi-mezîdi ‘inâyeti'l-meliki'd-dâ'im Dergâh-1 Mu'allâm Kapucubaş1larından Mütesellim Ahmed Bey dâme mecdühu ve mefâhirul-kuzât ve'l-hükkâm ma‘denü'l-fazlı ve'l-kelâm Adana kâdîsı ve Adana sancağında vâk1' kâzaların ${ }^{55}$ kâdîları ve nâ'ibleri zîde fazluhum ve mefâhirü'l-emâsil ve'lakrân a yân ve zâbitân vücûh-1 vilâyet ve iş erleri ve bu husûsa mübâşir ta'yîn olunan sadr-1 a'zamım çukadârlarından İsmail zîde kadrühum tevkî‘-i refî‘-i hümâyûn vâsıl olıcak ma’lûm ola ki:

Sâbıkan hazret-i seraskerî ve hâlen Sayda vâlîsi düstûr-1 mükerrem müşir-i mufahham nizâmü'l-'âlem vezîrim edâme Allâhu ta'âlâ iclâlehu ma'iyyetine mevcûd bulunub hidemât-1 lâzımede istihdâm olunmak içün geçen sene Adana sancağından tertîb olunan yüz elli mehâr şütürândan Adana kazâsına isâbet eden elli bir mehârı mübâşirîne teslîmen ser asker-i müşârün ileyh ma'iyyetine irsâl olunmuş olub mâ‘adâ tekemmülü terettüb (ü) iktizâ eden doksan dokuz mehârın 'icâleten ihrâc ve irsâli içün emr-i şerîfim 1sdâr ve ba'dehu bi'd-defe'ât te 'kîd ve isti“câlî olunmuşken el-ân bekāyā-yı mezkûrun bir mehârı irsâl olunmadıkdan gayrı şimden sonra dahi luzûmu olmamakdan nâşî emsâli üzere beher mehârı yüz ellişer guruşdan îcâb eden on dört bin sekiz yüz elli guruş bedellerin tahsîli5' husûsuna irâde-i 'aliyyem ta'alluk etmekle mütesellim-i mûmâ ileyhsin işbu emr-i şerîfimle ta'yîn olunan mübâşir-i merkûm tarafına vâsıl olduğu gibi hisselerini edâ etmeyen kazâlar ahâlilerine ma 'rifetin ve ma'rifet-i şer'le ve cümle ma'rifetiyle tevzî‘ ve yerlü yerinden serî‘ân ve 'âcilen tahsîl ve mübâşir-i merkûma teslîmen ordu-yı hümâyûnum hazînesine irsâl ve tesyîre ihtimâm ü dikkat eylemen fermânım olmağın hâsseten işbu emr-i celîlü'l-kadrım ısdâr ( ） ve ile irsâl olunmuşdur. İmdi vusûlünde ber minvâl-i muharrer tertîb-i mezkûrdan gayr-1 ez ihrâc bekāyā kalan doksan dokuz mehârın beher mehârı yüz ellişer guruşdan sâlifü’z-zikr olan dört bin sekiz yüz elli guruş hisselerini edâ etmeyen kazâlar ahâlilerine ma'rifetin ve ma'rifet-i şer' ve cümle ma'rifetiyle tevzî' ve taksîm ve kimesnenin a'zâr-1 vâhiyyesine kat'an cevâbına sem'-i i'tibâr etmeyerek birkaç gün zarfında 'icâleten ve müsâra'aten yerlü yerinden cem' ü tahsîl ve mübâşir-i merkûma teslîmen ordu-yı hümâyunum hazînesine irsâl ve tesyîre ihtimâm ü dikkat idüb hilâf-1 rızâ-y1 'aliyyem bî-hûde tahrîrât irsâl ve âher gûne a'zâr-1 vâhiyye îrâdından ziyâde tehâşî ve mücânebet eyleyesin ve sen ki mübâşir-i merkûmsun işbu emr-i şerîfimle icâleten ol tarafa varub me'mûr-1

55 Metinde kâdîların yazılmıştır.

56 Kâtip tahsîl, teslîm gibi tef' îl bâbındaki kelimeleri tahassül, tesellüm şeklinde tefe "ül bâbında yazmaktadır. 
tahsîl olduğun meblağ-1 mezbûru mütesellim-i mûmâ ileyhin ma'rifeti ve ma'rifetin ve cümle ma'rifetleriyle hisselerini edâ eylemeyen kazâlardan bi-eyyi hâlin tamâmen ve kâmilen tahsîl ve 'icâleten ve müsâra'aten getürüb ordu-yı hümâyûnum hazînesine teslîme ziyâde sa'y ü gayret ve hirâmet ${ }^{57}$-i meks ü ikāmetden ve tamâmen tahsîl etmedikçe 'avdet etmekten tehâşî ü mücânebet eyleyesin ve siz ki kuzât ve nüvvâb ve a'yân ve zâbıtan-1 mûmâ ileyhimsiz ve iş erlerisiz sizler dahi mûcib-i emr-i şerîfimle 'amel ü hareket ve meblağ-1 mezbûrun bir an akdem tahsîli husûsuna bezl-i tâmm ü makderet ve hilâfından gâyetü'l-gâye ittikâ ve mübâ'aded eylemeniz bâbında fermân-1 'âlîşânım sâdır olmuşdur. Hükm-i şerîfimle ( ） vardıkda bu bâbda vech-i meşrûh üzere şeref-yâfte-i sudûr olan işbu emr-i şerîf-i 'âlîşân-1 vâcibü'l-ittibâ ve lâzımü'l-imtisâlimin mazmûn-1 münîfi üzere 'âmil olasız. Şöyle bilesiz 'alâmet-i şerîfe i'timâd kılasız. Tahrîren gurre-i Şabânü'l-mu'azzam sene erbâ' ve mi'eteyn ve elf.

Be-yurd-1 sahrâ-yı Gazze. 
Sira No : 4

Belge No : Adana Ş.S. 55, img. 64, sayfa 126, belge 62

Tarih : Evâhir-i ZA 1204 / 2- 11 Ağustos 1790

Konu : : Ahmed Bey’in 1.000 nefer asker ile Fransızlara karşı Mısır'da ordu-yı hümâyûna katılmasına dair fermân.

İftihârü'l-emâcid ve'l-ekârim câmi 'u'l-mehâmid ve'l-mekârim el-muhtassu bi-mezîdi 'inâyeti'l-meliki'd-dâ'im Dergâh-1 mu'allâm kapucıbaşılarından Adana Mütesellimi Mîr Ahmed dâme mecdühu tevkî'-i refî‘'-i hümâyûn vâsıl olıcak ma'lûm ola ki:

Bundan akdem sâdır olan emr-i şerîfimde beyân olduğu üzere derûn-1 Misır'a duhûl iden Misır vâlisi ve ümerâ-yı Mısrıyye sadr-1 a'zamım kethüdâsı ve sâ'irleri ahâli-i Misır ile bi'l-ittifâk Misır'1 zabt ve kâffe-i memerr ü ma 'berleri sedd (ü) bend ve toplar vaz' ve ta ‘biye ile gereği gibii ${ }^{58}$ istihkâm virüb hâricde olan kefere tarafından ne zamân hücûm ve iktihâm olundukca bâ-avn ü 'inâyet-i cenâb-1 Bârî ve imdâd-1 ruhâniyye-i hazret-i risâlet-penâhî bir vechile zafer-yâb olmayub münhezimen girü 'avdet itdikden gayrı derûn-1 Misır'da olan ehl-i imân (ü) şüce 'ân çend def'a taşra küffâr üzerine hücûm ü savletde bir zamân eylediklerinde beş kıt'a toplarını ahz ve binden mütecâviz kefere-i dûzah-karîni kantara-i süyûfdan güzerân eyledikleri ve 'urbân-1 havâli-i Mısır dahi ahâli-i Mısır ile ittifâk idüb a'dâ-yı dîn-i hazelâ-fakr yine cevânib ü etrâfdan îsâl-1 hasâr ü gezende mübâderet etmiş oldukları bu def'a vârid olan haberden müstebân ve küffâr ile dîn yoluna muhârebe ve mukātele üzere olan dîn karındaşlarına imdâd ü i'ânete müstetâben ${ }^{59}$ kâffe-i mü'minîne farz-1 'ayn olduğu ve işbu günlerde ordu-y1 hümâyûnumda müte'âkıben asker-i vâfiye irsâliyle imdâd olunduğu sûretde Allâhu ta'âlâ inâyetiyle havâli-i merkûmede olan kefere külliyen makhûr ve müdemmere olacağ 1 ve işbu vakt evkāt-1 sâ'ireye bir vechile makyes olmayub tamam dîn-i mübîne ve devlet-i 'aliyyeme hizmet cümleye farz idüğü bedîhi ü a'yân ve bu def'a ordu-y1 hümâyûnumda emirü’l-ümerâ'i'l-kirâm Tâhir dâme ikbâluhu bin nefer asâkir ile irsâl verâsında vüzerâ-i 'izâmımdan biri dahi asâkir-i vefîre ile îsâl olunmak üzere idüği ve ba'dehu sadr-1 a'zam-1 sütûde-şiyem ve serdâr-1 ekrem-i kaviyyü'l-himem dahi tesyîr ${ }^{60}$ oluna. Etrâfdan tevârüd üzere asâkiri istishâb iki mükemmel top ve cebehâne ile 'azîmete müteheyyî olduğu zâhir ve nümâyân olmakdan nâşî sen ki kapuc1-1 mûmâ ileyhsin işbu emr-i şerîfim sana vâsıl olduğu sâ'atde bundan akdem sâdır olan emr-i şerîfim mûcebince me'mûr-1 tahrîri olduğu bin nefer piyâde asker ile bi'n-nefs hareket ve seyr-i serî‘ ile ordu-yı hümâyûnuma vusûle sarf-1 nihâyete vus` ü miknet eylemen fermânım olmağın te'kîden ve isti'câlen ve tenbîhen ve istid'â mahsûs işbu emr-i şerîfim isdâr ve 'alâ cenâhi’t-ta'cîl sadr-1 a'zamım çukadârlarından kıdvetü’l-emâsil ve'l-akrân Ali zîde kadrühu ile tisyâr olmuşdur. İmdi asker-i mezkûr ile birkaç gün zarfında ordu-yı hümâyûnumda isbât-1

58 Metinde "ker gibi" şeklinde yazılmıştır.

59 Metinde bu şekilde yazılmışsa da anlam bakımından şitâb kelimesi daha uygundur.

60 Metinde teseyyür şeklinde yazılmıştır. 
vücûd eylemen ne mertebelerde ikdâm umûr-1 dîn (ü) devlet-i 'aliyyemden olduğu ve ma'âze Allâhu ta'âlâ bu emr-i ehemm-i dînde iğmâz ü betânet ve ifâte-i vakti mûcib olur harekete cür'et dînen ve ahiretde müntec-i vehâmet ü nedâmet olacağı ma'lûm-1 gayret-melzûmun oldukda senden me'mûl ve mütezâhir-i şâhânem olan hamîde ve gayreti işbu günlerde tamâmıla ibrâz (ve) der-uhde ederek vusûl-1 emr-i şerîfimde sâlifü'l-beyân me'mûr-1 tahrîri olduğun bin nefer piyâde asker güzîde ve müntehab olarak bi'n-nefs istishâb ile bir nefes akdem isbât-1 vücûd eylemeğe sarf-1 mâ-hasal ${ }^{61}$ vus ${ }^{6}-1$ makderet ve münâfi-i tenbihât-1 şâhâneme kusûr vaz ve imrâr-1 vakti mûcib harekete müsâceretü'l-gâyeti'l-gâye mücânebet eylemen bâbında fermân-1 'âlîşânım sâdır olmuşdur. Buyurdum ki:

Hükm-i şerîfim vusûlünde bu bâbda şeref-rîz olan fermân-1 vâcibü'l-ittibâ' ve lâzımü'l-imtisâlimin mazmûn-1 müniffi üzere 'amel ü hareket idüb hilâfından hazer eyleyesiz. Şöyle bilesiz 'alâmet-i şerîfe i'timâd kılasız. Tahrîren evâhir-i şehr-i Zi'l-ka'de sene erba'a ve mi'eteyn ve elf.

Be-yurd-1 sahrâ-y1 Yafa. 
Sira No : 5

Belge No : Adana Ş.S. 61, img. 5, s. 17, belge 22

Tarih : : 9 Ş $1205 / 13$ Nisan 1791

Konu : Adana'da mevcut İhtisab ve Tevâbi'i Mukāta'alarının geliri olan 11.337 guruştan 4.257 guruşun Ahmed ve Mehmed beylerden tahsil edilerek hazineye gönderilmesine dair.

Düstûr-1 mükerrem müşîr-i mufahham nizâmu'l-'âlem müdebbirü'l-umûri'l-cumhûr bi'l-fikri’s-sâkıb mütemmimü mehâmmi'l-enâm bi'r-re'yi's-sâ'ib mümehhidü bünyâni'd-devlet ve'l-ikbâl müşeyyidü erkâni's-sa ‘âdet ve'l-iclâl el-mahfûfu bi-sunûfi 'avâtıfi'l-meliki'l-a 'lâ hâlen Adana vâlîsi vezîrim Piri Süleymân Paşa edâme Allâhu ta'âlâ iclâlehu ve kıdvetü'l-kuzât ve'l-hükkâm ma'denü'l-fazlı ve'l-kelâm Mevlânâ Adana kâdîsı zîde fazluhu tevkî‘-i refî‘-i hümâyûn vâsıl olıcak ma’lûm ola ki:

Mevlânâ-yı mûmâ ileyhin Der-aliyyeme vürûd iden i'lâmı mefhûmunda Adana'da vâk1' ihtisâb ve tevâbi'i mukāta'asının iki yüz dört senesine mahsûben emâneten 'uhdelerinde olan Karsîzâde Es-seyyid Ahmed ve Es-seyyid Mehmed zîde kadrühumâ belde-i mezkûrenin perişânlığından nâşî tüccâr tâ'ifesinin adem-i vürûduna binâ'en sene-i mezbûre Martı ibtidâsından Şubatı gâyetine değin mukāta'a-i mezkûre mülhakātından ve gerek resm-i iskele-i Karataş ve gerek tevâbi'inden yedlerinde mevcûd masârıfât defteri mûcebince ba'de'l-harc ve'l-masraf fakat on bir bin üç yüz otuz yedi guruş hâsılât ve makbûzâtları olduğunu tahrîr ve inhâ etmekle mukāta'a-i mezbûrenin bir buçuk rub' hissesi mahlûl ve kusûr-1 şâhî sâbıkan Tersâne-i 'âmirem emîni Mehmed Emin dâme mecdühunun 'uhdesinde olub sâlifü’z-zikr on bir bin üç yüz otuz yedi guruş fâ'izinden hisse-i mûmâ-ileyhe isâbet edeni tarafindan meb 'ûs ademîsine teslîmen irsâl ve hisse-i mahlûle-i mezkûrenin fầizi olan dört bin iki yüz elli guruş mîr-i mûmâ-ileyhümânın zimmetlerinde olmağla sen ki vezîr-i müşârun ileyhsin zikr olunan dört bin iki yüz elli bir guruşu mûmâ ileyhümânın zimmetlerinde olmağla sen ki vezîr-i müşârun ileyhsin zikr olunan dört bin iki yüz elli bir guruşu mûmâ ileyhümâdan inzimâm-1 re'y ve ma'rifetin ve ma'rifet-i şer'le tahsîl ve teslîm-i Hazîne-i 'âmirem olunmak içün Der-'aliyyeme irsâl eylemek fermânım olmağın hâsseten işbu emr-i celîlü’l-kadrım 1sdâr ve ( ） ile irsâl olunmuşdur. İmdi vusûlünde sen ki vezîr-i müşârun ileyhsin bâlâda bast ü beyân olunduğu üzere sene-i mezbûra mahsûben mûmâ ileyhümâ mukāta'a-i mezbûreyi zabt idüb zimmetlerinde olan dört bin iki yüz elli bir guruşu inzimâm-1 re’y ve ma'rifetin ve ma'rifet-i şer'le tamâmen tahsîl ve hazîne-i 'âmireme teslîmi içün Der-'aliyyeme irsâle bezl-i cell-i himmet eyleyesin ve sen ki mevlânâ-yı mûmâ ileyhsin sen dahi mûcib-i emr-i şerîfimle 'amel ü hareket eylemen bâbında fermân-1 'âlîşânım sâdır olmuşdur. Buyurdum ki:

Hükm-i şerîfimle ( ） vardıkda bu bâbda vech-i meşrûh üzere şeref-yâfte-i sudûr olan işbu emr-i şerîf-i celîlü'ş-şân-1 vâcibü'l-ittibâ‘ ve lâzımü'l-imtisâlimin mazmûn-1 itâ‘at-makrûnuyla 'âmil olasız. Şöyle bilesiz 'alâmet-i şerîfe i'timâd kılasız. Tahrîren fî'l-yevmi’t-tâsi' Şa‘bâni'l-mu'azzam sene hamse ve mi'eteyn ve elf.

Bi-makāmı Kostantiniyyeti'l-mahrûse 
Sira No : 6

Belge No : Adana Ş.S. 57, img. 54, sayfa 103, belge 136

Tarih $\quad$ : Evail C 1206 / 26-01-04.02.1792

Konu : Kozanoğlu Deli Yusuf ve avenesi olan Farsak taifesine zahire verilmemesine dair fermân.

İftihârü'l-emâcid ve'l-ekârim câmi 'u'l-mehâmid ve'l-mekârim el-muhtassu bi-mezîdi inâyeti'l-meliki'd-dâ'im Dergâh-1 mu'allâm kapucubaşılarından Adana Mütesellimi Mîr Ahmed dâme mecdühu ve mefâhirü'l-emâsil ve'l-akrân Karsantıoğlu ve Şeyhi(?) ve Kara Hacılu ve Kürkçü ve Karacalu boybeyileri ve Bozdoğan Boybeyisi Kerimoğlu ( ）zîde kadrühum tevkî'-i refî‘-i hümâyûn vâsıl olıcak ma'lûm ola ki:

Siz ki mütesellim ve sâ'ir mûmâ ileyhimsiz Kozanoğlu Deli Yusuf ve 'avenesi olan Farsak tâ'ifesine zahîre vermemek ve adamları zuhûr ider ise ahz ü girift olunmak ve kusûr ider olursa hakkından gelinmek husûsu Dergâh-1 Mu'allâm Kapucıbaşılarından ber vech-i mâlikâne Bozok sancağı mutasarrıfı iftihârü'l-emâcid ve'l-ekârim Cabbarzâde Mîr Süleyman dâme mecdühu tarafindan size tenbîh ve te 'kîd olunmuş idüğü bu def'a mîr-i mûmâ ileyh tarafından vârid olan tahrîrâtdan müstebân ve evvel bahârda emr ü re'yiyle 'amel ü harekete mübâderet ve hilâf vaz'dan mübâ‘adet ve ma‘âze Allâh tevsî‘i bâbında ednâ mertebe rehâvet ve yâhûd hafî ü celî merkûmûn tarafina zehâyir ve cihet-i sâ'ire ile i'ânet olunduğu ihbâr olunmak lâzım gelür ise beher hâl mazhar-1 gazab-1 mülûkânem olacağınız mukarrer ve muhakkakdır ana göre tahsîl-i rızâ-yı şâhâneme müsâra'at eylemeniz fermânım olmağın tenbîhen ve ihtimâmen mahsûsan işbu emr-i şerîfim isdâr ve ( ） ile irsâl olunmuşdur. İmdi mîr-i mûmâ ileyhin emr ve re'yiyle 'amel ü harekete dikkat eylemeniz matlûb-1 mülûkânem olduğu ve hilâf-1 fermân emr ü re'yinden hâric hareket ve zehâyir ve hubûbât-1 sâ'ire ile i'ânet ider iseniz hakkınızda mu'âmele-i aher icrâ olunacağı ma'lûmunuz oldukda ber vech-i meşrûh 'amel ü harekete bezl ü sa'y ve ihtimâm ve hilâfı vaz'a cesâretle mazhar-1 eşedd-i 'ikâb-1 şâhânem olmakdan ittikâ'-i tâmm eylemeniz bâbında fermân-1 'âlîşânım sâdır olmuşdur. Buyurdum ki:

Vusûl buldukda bu bâbda vech-i meşrûh üzere şeref-yâfte-i sudûr iden fermân-1 vâcibü'l-ittibâ‘ ve lâzımü'l-imtisâlimin mazmûn-1 itâ'at-makrûnuyla 'amel ü hareket ve ser-i mû hilâfından hazer ü mücânebet eyleyesiz. Şöyle bilesiz 'alâmet-i şerîfe i'timâd kılasız. Tahrîren fî evâ'il-i şehr-i Cemaziye'l-ahir sene sitte 'aşere ve mi'eteyn ve elf. (Evail C 1206, 26-01-04.02.1792)

Be-makām-1 Mahrûsa-i Kostantiniyye. 
Sira No : : 7

Belge No : Adana Ş.S. 63, img. 16, sayfa 53, belge 81

Tarih $\quad$ : 01 ZA $1206 / 21.06 .1792$

Konu : Ahmed Bey’in Adana serdarlığına tayin olunduğuna dair Yeniçeri Ağası mektubu.

Şer'iat-şi'âr Adana kâdîsı efendi zîde fazluhu ba'de's- selâm inhâ olunur ki:

Taht-1 hükûmetinizde serdâr olan ref' olunub yerine uslûb-1 sâbık üzere kıdvetü'l-emâsil ve'lakrân Hasanpaşazâde Ahmed Bey zîde kadrühu serdâr nasb olunmağın işbu mektûb tahrîr ve irsâl olunmuşdur. İnşa'e Allâhu ta‘âla vusûlünde gerekdir ki merkûmu kazâ-i mezkûrun serdârlığı umûrunda kıyâm ve öteden berü olageldiği vechile zabt ü rabtı husûsunda i'ânet ve ihtimâm eyleyesiz ve sen ki serdâr-1 merkûmsun kazâ-i mezkûrun serdârlığı sana tefvîz olunmağla gerekdir ki kâ'ide-i kadîm ve kānûn üzere zabt ü rabt-1 neferât ve def' ü ref'-i haşerât ile tanzîm-i bilâd ve irâde-i hâl-i 'ibâda bezl-i iktidâr eyleyesin ve kazâ-i mezkûrda mukîm ve müsâfir yeniçerileri ve cebeci ve topcu ve top arabacısı ve g1lmân-1 'acemi ve kuloğulları bi'l-cümle seni üzerlerine serdâr ve zâbit bilüb sözünden taşra ve re'yinden hâric vaz‘ u hareketde bulunmayub dâ‘imâ itâ'at ü inkıyâd üzere olalar ve sen dahi cümle umûrunu ahkâm-1 şer'-i şerîf ve kānûn-1 kadîm ve emr-i münîfe tatbîk ve tevâ'if merkûmûndan bilâ vâris-i ma'rûf fevt olanların metrûkâtların ma'rifet-i şer'le zabt ve sûk-1 sultânîde füruht ve hâsıl olan nükûdun cânib-i beytü'l-mâl içün defter müfredâtıyla ocak tarafina göndermeğe mübâderet ve beher hâl sükkân-1 vilâyetin emr ü râhatlarına bâ' is hizmet-i müstahsene-i mebrûre vücûda getürmeğe mucidd ü sâ'i olub mûcib-i mektûb ile 'âmil olasız.

Tahrîren gurre-i şehr-i Zi'l-ka'de sene sitte ve mi’eteyn ve elf.

El-fakîr

Ahmed Ağa-y1 Yeniçeriyân-1 dergâh-1 'âlî

hâlen 
Sira No : 8

Belge No : Adana Ş.S. 63, img. 23, sayfa 81, belge 111

Tarih : :25 M 1207 / 12 Eylül 1792

Konu : Ahmed Bey, Mehmed Bey ve Mustafa Bey'den Yörügân-1 Adana, Tarsus ve Sis Mukāta'aları için 1201 senesinden 1206 senesine geçen süre zarfında gönderilenler dişında kalan birikmiş borçları 44.910 guruşun tahsîl edilmesine dair fermân.

Düstûr-1 mükerrem müşir-i mufahham nizâmü'l-'âlem müdebbiru umûri'l-cumhûr bi'l-fikri's-sâkıb mütemmimu mehâmmi'l-enâm bi-re'yi's-sâ'ib mümehhidü bünyâni'd-devle ve'l-ikbâl müşeyyidu erkâni's-sa‘âde ve'l-iclâl el-mahfûfu bi-sunûfı 'avâtıfi'l-meliki'l-a'lâ Adana vâlîsi vezîrim İbrahim Paşa edâme Allâhu ta âla iclâlehu ve kidvetü'l-kuzât ve'l-hükkâm ma'adinü'l-fazlı ve'l-kelâm Mevlânâ Adana kâdîsı zîde fazluhu ve kıdvetü erbâbi’t-tahrîr ve'l-kalem 'umdetü ashâbi't-takrîr ve'r-rakam Başmuhâsebe Kalemi ketebesinden olub bu husûsa mübâşir ta'yîn olunan Hafız Mehmed Emin zîde rüşdühu tevkî‘-i refî‘-i hümâyûn vâsıl olıcak ma'lûm ola ki:

Bu esnâda masârıf-1 mühimme-i mîriyyenin terâküm ve tahâcümü derkâr olmakdan nâşî Âsitane-i 'aliyyem ve taşrada bulunanların zimmetlerini müctemi' ${ }^{62}$ olan emvâl-i mîriyye ve mutâlebât-1 sâ'irenin 'icâleten tahsîline ikdâm olunmak vâcibât-1 umûrdan idügü derkâr olmağla sâbıkan Adana Mütesellimi Hacı Ali Bey ve karındaşı müteveffâ Abdullah Bey’in oğulları Mîr Mustafa ve Mîr Mehmed ve Ahmed zîde kadrühümânın 'uhdelerinde olan Cemâ'athâ-yı Yörügân-1 Adana ve Tarsus ve Sis Mukāta'ası'nın senevî dokuz bin sekiz yüz altmış dokuz buçuk guruş mâl-1 mîrîsi olub ber mûceb-i şurût-1 mâlikâne meblağ-1 mezbûrun senesi derûnunda nakden hazîne-i 'âmireme ve havâle olunan mahallere tamâmen edâ ve teslîm birle te' diye-i zimmet olunmak lâzıme-i zimmetleri iken mukāta'a-i mezbûrun iki yüz bir senesinden iki yüz altı senesine gelince gayr-1 ez havâlât kırk dört bin dokuz yüz on guruş zimmet-i sahîh deyn-i sarîhleri olduğu hazîne-i 'âmiremde mahfûz başmuhâsebe defterlerinden muhrec bir kıt'a mümzâ sûret-i defterden müstebân olmağla meblağ-1 mezbûrun bundan sonra kat'an te 'hîr ve tevkîf olunmayarak ber mûceb-i şurût-1 mâlikâne mîr-i mûmâ ileyhden 'alâ eyyî hâlin tahsîl ve hazîne-i 'âmireme teslîmi husûsuna irâde-i mülûkânem ta 'alluk itmekle hâsseten işbu emr-i 'âlîşânım 1sdâr ve mübâşir-i mûmâ ileyh ile irsâl olunmuşdur. Bi-mennihi ta'âla vusûlünde sen ki vezîr-i müşârün ileyhsin bundan sonra bir an te'hîr ve tevkîfe ruhsat göstermeksizin meblağ-1 mezbûreyi inzimâm-1 re'y ve ma'rifetin ve ma'rifet-i şer' ve mûmâ ileyh mübâşeretiyle mîr-i mûmâ ileyhimden bir an akdem ve bir sa'ât mukaddem 'alâ eyyi hâlin tahsîl ve tekmîl ve mübâş̧ir-i mûmâ ileyhe teslîmen Der-sa'âdetime irsâle mezîd-i ihtimâm ü gayret ve hilâf-1 rıâ-y1 şâhânem imrâr-1 vakitden mücânebet eylemelerini mîr-i mûmâ ileyhime gereği gibi tenbîh eyleyesin ve sen ki mübâşir-i mûmâ ileyhsin sen dahi me'mûl olan sadâkat ve istikā- 
met muktezâsınca ${ }^{63}$ mukāta a-i mezbûrun sinîn-i merkûme emvâlinden gayrı ez havâlât mîr-i mûmâ ileyhin zimmetlerinde ${ }^{64}$ müctemi` olan meblağ-1 mezbûru müşârun ileyhin inzimam-1 re’y ve ma'rifeti ve ma'rifet-i şer' ve mübâşeretinle bi'l-ittifâk tahsîl ve tekmîl ve gönderüb hazîne-i 'âmireme teslîme ziyâde sa'y ü ikdâm birle hilâf-1 emr ve mugâyir-i rızâ-i 'aliyyem bî-hûde tevkîf ve ikdâmından ve ihmâl ve mümâsahadan ${ }^{65}$ ihtirâz-1 tâmm eyleyesin ve sen ki kâdî-1 mûmâ ileyhsin sen dahi emr-i şerîfime imtisâl ve mutâba'at ve mübâşir-i mûmâ ileyhsin (min) külli vücûh mu'âvenet ve müzâheret ve hilâfından mübâ'adet eylemen bâbında fermân-1 'âlîşânım sâdır olmuşdur. Buyurdum ki:

Hükm-i şerîfim ( ） vardıkda bu bâbda vech-i meşrûh üzere şeref-yâfte-i sudûr olan işbu emr-i şerîf-i celîlü'ş-şân-1 vâcibü'l-ittibâ‘ ve lâzımü'l-imtisâlimin mazmûn-1 itâ‘at-makrûnuyla 'amel idesiz ve's-selâm. Hurrire fi'l-yevmi'l-hâmis '1şrin şehr-i rebî‘ü’l-ahir sene seb'a ve mi'eteyn ve elf.

Be-makām-1 mahrûsa-i Kostantiniyye 
Sira No : 9

Belge No : Adana Ş.S. 56, img. 23, sayfa 57, belge 30

Tarih : : 11 Ş $1211 / 13$ Şubat 1793

Konu : Cümle Adana uleması ve Adana eski mütesellimi Ahmet Bey ve askeri taifesinin Eski Adana Müftüsü Şeyh Mehmet Efendi’nin canına ve malına dokunulmayacağına ilişkin mahkemede verdikleri teminat hüccetidir.

Medine-i Adana' da vâk1' bi' l-cümle 'ulemâ ve sülehâ e' imme ve hutebâ ve müderrisîn-i kirâm-1 zevi'l-ihtirâm ve sâbıkan Adana Mütesellimi Hasanpaşazâde necâbetlü Ahmed Bey Hazretleri ve sâ'ir ağavât bi-ecma 'ihim meclis-i şer'-i şerîf-i enverde sâbıkan Adana' da me’zûn-ı bi'l-iftâ işbu bâ‘isü-1 kitâb Eş-şeyh El-hâcc Mehmed Efendi mahzarında şöyle ikrâr-1 tâmm ve takrîr-i kelâm ederler ki:

Bundan akdem ber muktezâ-yı vakt ü hâl efendi-i mümâ-ileyh ile ba'zı bürûdet ve münâfese zuhûr evhâm-1 hayâlâta teba'iyyet ve vesveseye zâhib olub emniyet itimâs etmekle fîmâ ba'd efendi-i mûmâ ileyhden kavlen ve fi'ilen kimesnenin mâlına ve canına sû-i kasd etmedikce ve kendü hâlinde olub umûr-1 beldeye emniyet iltimâs etmekle fimâ ba'd efendi-i mûmâ ileyhden kavlen ve fi'‘ilen kimesnenin mâlına ve canına su'i-kasd etmedikce ve kendü hâlinde olub umûr-1 beldeye ihtilât etmedikce taraflarımızdan dahi kendüye ve mâl ve canına sû'i-kasd etmeyüb ve eder olur ise def'-i ref'ine gayret-i kâmile olunmak üzere mukâvele ve mu'âhede olunub meyânemizde bu gûne sudûr eden tarafeynin ikrâr ve tasdîkini mübeyyin hafazan li'l-makal vesîka-i enîka tahrîr ve efendi-i mûmâ ileyh yedine i'tâ olunması matlûbumuzdur dediklerinde gibbe't-tasdîki'ş-şer'i mâ-vaka'a bi't-taleb ketb olundu. Hurrire fi'l-yevmi'l- hamis-i aşer min şehri Şa ‘bâni’l-mu'azzam li sene ihdâ ve aşer ve mi’eteyn ve elf. 
Sira No : 10

Belge No : Adana Ş.S. 63, img. 32, sayfa 116, belge 143

Tarih $\quad$ : 01 ZA1207/10.06.1793

Konu : Ahmed Bey'in Adana serdarlığına tayin olunduğuna dair

Paşabeyzâde'nin serdârlık mektûbu

Şer'iat-şi ‘ar Adana kâdîsı efendi zîde fazluhu ba'de’s-selâm inhâ olunur ki

Taht-1 hükûmetinizde serdâr olan ref' olunub yerine uslûb-1 sâbık üzere kıdvetü'l-emâsil ve'lakrân Abdullahpaşazâde Ahmed Bey zîde kadrühu serdâr nasb ü ta 'yîn olunmağın işbu mektûb tahrîr ve irsâl olunmuşdur. İnşâ'e Allâhu Ta'âlâ vusûlünde gerekdir ki merkûmu kazâ-i mezkûrun serdârlığı umûrunda kıyâm ve öteden berü olageldiği vechile zabt ü rabtı husûsunda i'ânet ve ihtimâm eyleyesiz ve sen ki serdâr-1 merkûmsun kazâ-i mezkûrun serdârlığg sana tefvîz olmağla gerekdir ki kâ‘ide-i kadîm ve kānûn-1 münîf üzere zabt ü rabt-1 neferât ve def'-i ref'-i haşerâtıyla tanzîm-i bilâd ve irâde-i hâl-i 'ibâda bezl-i iktidâr eyleyesin ve kazâ-i mezkûrda mukîm ve müsâfir yeniçerileri ve cebeci ve topcu ve top arabacısı ve gilmân-1 'acemi ve bi'l-cümle kuloğulları seni üzerlerine serdâr ve zâbit bilüb sözünden taşra ve re'yinden hâric vaz' u hareketde bulunmayub dâ'imâ itâ'at ve inkıyâd üzere olalar ve sen dahi cümle umûrunu ahkâm-1 şer'-i şerîf ve kānûn-1 kadîm ve emr-i münîfe tatbîk ve tavâ'if-i merkûmûnun bilâ vâris-i ma'rûf fevt olanların metrûkâtların ma'rifet-i şer'le zabt ve sûk-1 sultânîde fürûht ve hâsıl olan nükûdun cânib-i beytü'l-mâl içün defter müfredâtıyla ocak tarafına göndermeğe mübâderet ve beher hâl mûcib-i mektûb ile 'âmil olasız. Tahrîren gurre-i şehr-i zi'l-ka'de sene seb‘a ve mi’eteyn ve elf.

El-fakîr

Mustafa Ağa-yı Yeniçeriyân-1 dergâh-1 'âlî hâlen 
Sira No : : 11

Belge No : Adana Ş.S. 63, img. 32, sayfa 116, belge 144

Tarih $\quad$ : Gurre S $1208 / 08.09 .1793$

Konu : Adana'ya Ahmed Bey’in serdar olarak tayin edildiğine ilişkin Yeniçeri Ağası mektubu.

Şer‘iat-şi‘âr Adana kâdîsı efendi zîde fazluhu ba'de’s- selâm inhâ olunur ki:

Taht-1 hükûmetinizde serdâr olan ref' olunub yerine üslûb-1 sâbık üzere kıdvetü'l-emasil ve'lakrân Abdullah Paşazâde Ahmed Bey zîde kadrühu serdâr nasb ü ta ‘yîn olmağın işbu mektûb tahrîr ve irsâl olunmuşdur. İnşâ'e Allahu ta'âlâ vusûlünde gerektir ki merkûmu kazâ-i mezkûrun serdârlığg umûrunda kıyâm ve öteden berü olageldiği vechile zabt u rabtı husûsunda i'ânet ve ihtimâm eyleyesüz ve sen ki serdâr-1 merkûmsun kazâ-i mezkûrun serdârllğı sana tefvîz olunmağla gerektir ki kâ'ide-i kadîm ve kānûn üzere zabt u rabt-1 neferât ve def' ü ref'-i haşerâtıyla tanzîm-i bilâd ve irâde-i hâl-i 'ibâda bezl ü iktidâr eyleyesin ve kazâ-i mezkûrda mukîm ve müsâfir yeniçerileri ve cebeci ve topcu ve top arabacısı ve kul oğulları bi'l-cümle seni üzerlerine serdâr ve zâbıt bilüb sözünden taşra ve re’yinden hâric vaz' ü hareketde bulunmayub dâ'imen itâ'at ve inkıyâd üzere olalar ve sen dahi cümle umûrunu ahkâm-1 şer'-i şerîf ve kānûn-1 kadîm ve emr-i münîfe tatbîk ve tevâ'if-i merkûmûndan bilâ vâris-i ma'rûf fevt olanların metrûkâtların ma'rifet-i şer'le zabt ve sûk-i sultânîde fürûht ve hâsıl olan nükûdun cânib-i beytü'l-mâl içün defter müfredâtıyla ocak tarafına göndermeğe mübâderet ve beher hâl sükkân-1 vilâyetin emn ü râhatlarına bâ'is hizmet-i müstahsene-i mebrûre vücûda getürmeğe mucidd ü sâ‘̂̂ olub mûcib-i mektûbla ‘âmil olasız. Tahrîren gurre-i şehr-i Saferü’l-hayr sene semâne ve mi'eteyn ve elf.

El-fakîr Mustafa Ağa ‘ulemâ-y1 yeniçeriyân-1 dergâh-1 'âlî hâlen. 
Sira No : 12

Belge No : Adana Ş.S. 56, img. 30, sayfa 71, belge 8

Tarih : :25 RA $1210 / 9$ Ekim 1793

Konu : Adana Mütesellimi Ahmed Bey’in Kethüdâ-i silâhşör-i hâssa-i hazret-i şehriyârisi olan El-hâcc Halil Ağa’ya verilen 300 guruşun tamâmen teslim alındığına dair.

Bâ'is-i tahrîr-i hurûf oldur ki:

Bin iki yüz on senesinde Adana mütesellimi inâyetlü Ahmed Bey efendimiz hazretlerinin hidmet-i“ aliyyelerinde istihdâm olan kethüdâ-i silâhşör-i hâssa-i hazret-i şehriyâri sa âdetlü Elhâcc Halil Ağa hazretleri karz-1 hasen olmak üzere üç yüz guruş virilüb yedlerinden bir kıt‘a temessük ahz olunmuşidi. Zikr olunan mebâliğ tamâmen ve kâmilen tarafimıza edâ ve teslîm olunub ağa-yı mûmâ ileyhin temessük-i mezkûru 'indimizde zâyi' olmağla şimden sonra temessük zuhûr ider ise 'amel olunmamak içün tarafımızdan edâsını müş 'ir işbu halâs virilmişdir. Vakt-i hâcetde ibrâz olunub senedimiz ile 'amel oluna. Hurrire fî 25 RA sene 1210

Bende

Makdisî Mıgırdiç Çadırcıoğlu M.

Şühûdu'l-hâl

Sa'âdetlü Vanî Mehmed Ağa

Ser-turnâ-i sa'âdetlü Es-seyyid El-hâcc Mustafa Ağa

Çukadarzâde Sa'âdetlü Abdülgani Ağa

Şerâfetlü Ateş Ali Efendi

Kâtib-i Divân Aşuzâde Osman Efendi

Alemdâr Mahmud

Sunullah Çelebi

Camuşcı Mustafa

Araboğlu Mehmed ve gayrühum 
Sira No : 13

Belge No : Adana Ş.S. 63, img. 7, sayfa 20, belge 22

Tarih $\quad$ : 23 R $1208 / 28.11 .1793$

Konu : Adana Serdarı Ahmed Bey'in Askeri Beytülmala memur ettiği Başçavuş Hacı Güllü Ahmed Beşe adlı şahsın Debbağan Mahallesi sakinelerinden Emine binti Hasan adlı hanımın kocası Bakkal Mamlı Beşe'nin vefatından sonra eşi Emine Hanım’a kalan metrukâtı üzerinde hak talep etmesine dair.

Hâlen medine-i Adana serdârı Abdullah Paşazade sa'âdetlü Ahmed Bey hazretleri tarafından 'askerî beytü'l-mâlına me'mûr Başçavuş Hacı Güllü Ahmed Beşe nâm kimesne meclis-i şer'i hatîr-i lâzımü’t-tevkîrde medine-i mezbûre mahallâtından ve Debbağan mahallesi sâkinelerinden işbu râfi'atü'l-kitâb Emine binti Hasan nâm hatun mahzarında üzerine şöyle da'vâ ve takrîr-i kelâm idüb târîh-i kitâbdan bir gün mukaddem bi-emri'llahi ta âla fevt olan işbu merkûme Emine’nin zevci Bakkâl Mamlı(?) Beşe nâm müteveffânın zevce-i merkûmesinden gayr-1 zâhirde vâris-i ma'rûf ve ma'rûfesi olmayub terekesi 'askerî beytü'l-mâlına 'â'id ve râci‘ olmağla mahalle-i mezbûrede vâk1' beyne'l-ahâli ve'l-ceyrân ma'lûmu'l-hudûd bir bâb fevkânî ve tahtânî ve yine bir bâb tahtânî buyût ve bir mikdâr havluyu müştemil müteveffâ-y1 merkûmun menzilini işbu merkûme Emine zabt idüb cânib-i beytü'l-mâla zabtıma mümâna'at ider sû'âl olunub takrîri tahrîr ve mûcib-i şer'isi ve (kesik) didikde gıbbe's-sû'âl mezbûre Emine dahi cevâbında fî'l-hakîka menzil-i mezkûr zevcim müteveffâ-yı merkûmun mülkü olub lakin kable'l-vefât hâl-i hayâtında ve kemâl-i 'akl ü sihhatinde zeyl-i vesîka(da) muharerü'l-esâmi-i müslimîn mahzarlarında zimmetinde mütekarrar ve ma'kûdun aleyh mehr-i mü'eccel-i müsemmâm olan iki yüz elli guruş ile yüz elli guruş karz-1 şer'î alacağım mukâbelesinde bana bey' ve teslîm ve temlîk idüb ben dahi ber vech-i meşrûh iştirâ ve kabûl ve tesellüm ve temellük eylemişidim deyü def`le mukâbele idicek gıbbe'l-istintâk ve'l-inkâr dâfi ‘a-i mezbûreden beyyine taleb olundukda 'udûl-i ahrâr-i ricâl-i müslimîn Es-seyyid El-hâcc Yiğen Ahmed Efendi ibni Hasan ve Hacı Ahmed ibni Molla Ahmed nâm kimesneler li-ecli'ş-şehâde meclis-i şer'de hâzırân olub eserü'l-istişhâd fî'l-hakîka müteveffâ-yı merkûm kable'l-vefât hâl-i hayâtında ve kemâl-i 'aklında ve sıhhatinde bizim huzûrumuzda kendi zimmetinde mütekarrer ve ma'kûdun aleyh merkûme Emine’nin mehr-i mü‘eccel-i müsemmâmı olan iki yüz elli guruş ile karz-1 şer'î yüz elli guruş hakkı mukâbelesinde menzil-i mahdûd-1 mezkûru bey' ve teslîm ve temlîk idüb ol dahi iştirâ ve kabûl ve tesellüm ve temellük idüb bu vechile beyt-i mezkûr el-yevm merkûme Emine'nin mülk-i müşterâsıdır. Bizler bu husûsa bu vech üzere şâhidleriz ve şâhidlik dahi ideriz deyü her birleri edâ-i şehâdet-i şer'iyye eylediklerinde ba'de'tta'dîl ve't-tezkîye şehâdetleri makbûl olmağın mûcebince müdde'i-i mezbûr bî-vech-i şer'i mu'ârazadan men' birle mâ vaka'a bi’t-taleb ketb olundu. Hurrire fî'l-yevmi’s-sâdis ve'l-'1şrîn şehr-i Rebî‘i'l-ahir sene semâne ve mi’eteyn ve elf.

Şuhûdü'l-hâl 
Vâ‘iz Es-seyyid El-hâcc Mehmed Efendi

Müsevvid Hac1 Mehmed Efendi

Es-seyyid Hac1 Ahmed Kabalc1

Karkızâde Hamza Çelebi

Haydarzâde Mehmed Ağa ve İbrahim Ağa

Kâtib Dürrî Hasan Efendi

Kâtib Es-seyyid Ali Efendi

Hilâlîzâde İsmail ve gayrühum. 
Sira No : 14

Belge No : Adana Ş.S. 66, img. 13, sayfa 63, belge 78

Tarih $\quad$ : 9 C $1208 / 12.01 .1794$

Konu : Hasanpaşazâde Mustafa Bey, Ahmed Bey ve Mehmed Bey’in malikâne olarak tasarruf ettikleri Cemaathâ-i Yörügân-1 Adana, Tarsus ve Sis Mukāta'alarının 1201-1209 senelerine ait zimmetlerinde kalan 59.768 guruşun tahsîli.

Kıdvetü'l-kuzât ve'l-hükkâm me'adinü'l-fazlı ve'l-kelâm Mevlâna Adana kâdîsı zîde fazluhu ve kıdvetü'l-emâcid ve'l-a ‘yân Hâssam silahşörlerinden Adanalı Karcızâde Mehmed zîde mecdühu ve zikr-i âtî akçanın tahsîline bu def'a mübâşir ta 'yîn olunan Defterdâr-1 Şıkk-1 Evvelim çukadârlarından El-hâcc Ahmed tevkī`-i refî‘-i hümâyûn vâsıl olıcak ma 'lûm ola ki;

Hasanpaşazâde Mustafa Bey ve Ahmed Bey ve Mehmed Bey'in mâlikâne 'uhdelerinde olan Cemâ'athâ-i Yörügân-1 Adana ve Tarsus ve Sis Mukāta'ası'nın iki yüz bir senesinden sekiz senesine gelince gayr-i ez-teslîm zimmetlerinde bâkî kalan emvâl-i mîriyyenin tahsîli irâde olundukda mâl-ı mîrî re 'âyâ zimmetlerindedir deyu cevâb verdiklerine mebnî ol vakitde Dergâh-1 Mu'allâm kapucubaşılarından Cabbarzâde Mîr Süleyman dâme mecdühu ma'rifetiyle re‘âyâdan on dört bin yedi yüz elli guruşu tahsîl ve Hazîne-i 'Âmireme irsâl ve teslîm birle mâ'adâ bakāyâ kalan kırk dokuz bin sekiz yüz doksan dokuz guruşun müte'ahhiren tahsîli bâbında sâdır olan emr-i şerîfim mîr-i mûmâ ileyh tarafına lede'l-vürûd Yörügân tâ'ifesi bu sene-i mübârekede 'âdet-i kadîmleri üzere yaylaklarına gidemeyüb havf ü haşyetlerinden vesveseye tâbi‘ olmalarıyla mîr-i mûmâ ileyh tarafından Derviş nâm kimesneyi mütesellim nasb ü ta 'yîn ve bekāyā-yı mezkûrun Yörügândan tahsîli husûsuna kendüye tenbîh eylediğine mebnî Der-'aliyyeme tevârüd eden kā'imesi mefhûmu emr-i mezkûrun kaydı bâlâsina şerh virilüb işbu dokuz senesi mâlı olan dokuz bin sekiz yüz bu kadar guruş dahî 'ilâve ile tahsîli lâzım gelen cem'an elli dokuz bin yedi yüz altmış sekiz guruşun te'kîdi hâvî işbu sene-i mübâreke Cemâziye'l-ûlâsı evâsıtında emr-i şerîfim verilmişidi. El-hâletü hâzihi bir akça zuhûr etmemekle sen ki silahşör-i mûmâ ileyhsin senden meşhûd olan fart-1 gayret ve tahsîl-i emvâl-i mîriyyede zuhûra gelen hamiyyetine nazaran bekāyā-yı mezkûrun tahsîl ve irsâli senden matlûb-1 şâhânem olmağla bu kadar külliyetlü emvâl-i mîriyyenin 'ukde-i te'hîre dûçârı ile karîn-i telef olmasına bir vechile rızâ-yı mülûkânem olmamağla mebâliğ-i mezbûru îcâb ve iktizâ idenlerden ma'rifetinle 'alâ eyyi hâlin tahsîl olunmak fermânım olmağın hâssaten işbu emr-i celîlü'l-kadrım 1sdâr ve mübâşir-i merkûm ile irsâl olunmuşidi.

İmdi vusûlünde mesârifât-1 mîriyyenin kesretine binâ'en akçanın eşedd lüzûmu olduğu ma'lûmun oldukda bâlâda tahrîr ü beyân olunduğu üzere mîr-i mûmâ ileyhimin ber-vech-i iştirâken 'uhdelerinde olan mukāta'a-i mezkûrun ikiyüz bir senesinden dokuz senesine gelince zimmetleri iktizâ eden elli dokuz bin yediyüz altmış sekiz guruşu ma'rifetin ve ma'rifet-i şer'le ve'l-hâs1l her ne vechile ve ne tarîkle olur ise olsun îcâb ve iktizâ idenlerden 'alâ eyyi hâlin tahsîl ve Hazîne-i ‘Âmireme irsâl ve tesyîre mezîd-i sa'y ü gayret ve hilâf-1 emr-i 'âlîşânım 
vaz‘ ü hareketden tahâşî ü mücânebet eyleyesin ve sen ki mübâşir-i merkûmsun tahsîline hâssaten me'mûr kılındığın mebâliğ-i mezbûru silâhşör-i mûmâ ileyhin ma'rifeti ve ma'rifet-i şer'le ve mübâşeretinle yerlü yerinden ve îcâb ve iktizâ idenlerden tamâmen ve kâmilen tahsîl ve yanına istishâb ve getürüb Hazîne-i 'Âmireme teslîm eylemeğe ziyâde sa'y ü gayret ve bî-hûde meks ü ikāmetten hazer ü mücânebet eyleyesin. Ve sen ki kādî-i mûmâ ileyhsin sen dahî mûcib-i emr-i şerîfimle 'amel ü hareket eylemen bâbında fermân-1 'âlîşânım sâdır olmuşdur. Buyurdum ki:

Hükm-i şerîfimle vardıkda bu bâbda vech-i meşrûh üzere şeref-yâfte-i sudûr olan işbu emr-i şerîf-i celîlü'ş-şân-1 vâcibü'l-imtisâl ve lâzimü'l-ittibâ‘'1mın mazmûn-1 itâ'at-makrûnu ile 'âmil olub hilâfından mübâ'adet eyleyesiz. Şöyle bilesiz; 'alâmet-i şerîfe i'timâd kılasız. Tahrîren fî'l-yevmi’l-hâmis Ramazan sene tis‘a ve mi’eteyn ve elf.

Kostantiniyye el-Mahrûse 
Sira No : 15

Belge No : Adana Ş.S. 66, sayfa 21, img. 34, belge. 26

Tarih $\quad$ : 26 C 1208 / 29.01.1794

Konu : Ahmed, Mehmed ve Mustafa Beylerin uhdelerinde olan Yörügân-1 Adana ve Tevâbi‘i mukāta'alarına, Yörügân-1 Bozdoğan Mukāta'asının mutasarrıfları olan Mustafa ve Sisli Kozanoğlu Yusuf'un ve Sis ve Çukurâbâd cânibinde mütemekkin olan Kerimli ve Melemenci ve Karakayalı ve Sırkıntılı ve Kürkcü aşiretlerinin kendi mukāta'alarına dâhil olduklarını iddia ederek zikr olunan aşiretlerden mâl-ı mîrî tahsîl ettiklerine dâir.

Kıdvetü'l-kuzât ve'l-hükkâm ma'denü'l-fazlı ve'l-kelâm Mevlânâ Adana kâdîsı zîde fazluhu ve k1dvetü'l-emâcid ve'l-a'yân hâssa silâhşörlerinden Adana mütesellimi zîde mecdühu tevkî̀'-i refî’-i hümâyûn vâsıl olıcak ma'lûm olaki:

Ve mefâhirü'l-emâcid ve'l-a ‘yân Ahmed Bey ve Mehmed Bey ve Mustafa Bey zîde mecdühumun divân-1 hümâyûnuma takdîm eyledikleri arzuhâlleri mefhûmunda bâ-berât-1 'âlî iştirâken mâlikâne 'uhdelerinde olan Yörügân-1 Adana ve Tevâbi'i mukāta'asının merbûtâtından olan Tarsus ve Sis ve Çukurabâd cânibinde mütemekkin olan Kerimli ve Melemenci ve Karakayalı ve Sirkıntılı ve Kürkcü ve sâ'ir 'aşîretlere ecânibden dahl (ü) ta'arruz eylemek îcâb etmez iken İçil sancağında vâkı' Yörügân-1 Bozdoğan Mukāta'asının mutasarrıfları kiler-i hâssam ağavâtından Mustafa ve Sisli Kozanoğlu Yusuf nâm kimesneler hilâf-1 kayd ü şürût "zikr olunan aşîretler bizim mukāta'amızın dâhilinde» diyerek 'aşâyir-i mezkûrenin üzerlerine edâsı lâzım gelen mîrîlerini tahsîl eylemek da'iyyesiyle bir k1t'a sûret-i berât ile ve bir k1t'a sûret-i fermân bir nefer bostancıya teslîmen 'aşîret-i mezkûreye irsâl eylediklerine mâl-1 mîrînin adem-i tahsîline ve bu vech ile mukāta'a-i mezbûrenin ihtilâline bâ'is olduklarını beyân ile mukāta'a-i mezbûrenin vech-i meşrûh üzere vâk1' olan ihtilâl sebebiyle mâl-1 mîrîsinin telef ve izâ'at olmakdan siyâneten merkûmânın hilâf-1 vāk1' müdâhalelerinin men' ü def'i içün emr-i şerîfim sudûrunu tahrîr ve istid'â ve ber minvâl-i muharrer Bozdoğan Mukāta'ası mutasarrıflarının hilâf-1 şürût aşîret-i mezkûreye irsâl eyledikleri berât ve fermân suretlerini ibrâz etmeleriyle hazîne-i 'âmirem defterleri kuyûdâtına mürâca'at olundukda vilâyet-i Anadolu' da vâk1' Adana ve Tarsus ve Sis câniblerinde sâkin Cemâ'at-1 Yörügân ve Tevâbi'i Mukāta'as1 senevî dokuz bin sekiz yüz kırk dört buçuk guruş mâl ve on üç bin beş yüz guruş mu'accele ile mîr-i mûmâ ileyhin ber vech-i mâlikâne 'uhdelerinde olduğu ve ibrâz olunan sûret-i berât ve sûret-i fermân kayda ve şürûta münâfî olmağla sahte olmak iktizâ eylediği ve zikr olunan Yörügân-1 Bozdoğan İçil mukāta'asının tamâmı bundan akdem mahlûlden bi'l-müzâyede yüz elli guruş mu'accele ile enderûn-1 hümâyûnum ağavâtından yalnız mûmâ ileyh Mustafa'ya tevcîh iki yüz yedi senesi evâ'il-i Şa‘ban'ında berât verildiği ve mukāta‘âteyn-i mezbûreteyn mutasarrıfları birbirinin mukāta'âlarına itâle-i dest-i ta'addi ile müdâhaleleri hilâf-1 şürût-1 mâlikâne idüğü mukayyed olmağla mukāta‘âteyn-i mezbûreteyn öteden berü ne vech ile zabt ü rabt ve hasılat ve rüsûmâtı ne tarafdan ahz ü kabz oluna gelmiş ise yine ol vechile ahz ü kabz 
olunub ahad-1 hümâ aherin mukāta'asını bî-vech ta 'addî ve müdâhale eylememek üzere kat' ( ) ${ }^{66}$...kalar emr-i şerîfim i'tâsı muktezâ-yı şürût idüğü mâlikâneden ve zikr olunan aşîretler hîn-i tahrîrde kangı mukāta'a tahtına kayd olunmuşdur. Su'al olundukda vilâyet-i Anadolu'da vâk1‘ İçil ve Teke ve Hamid ve Tarsus ve Adana ve Sis ve eyalet-i Karaman ve Menteşe ve Aydın ve Saruhan sancaklarında olan yörügân re‘âyâsı yüz otuz üç târîhinde ale'l-esâmi tahrîr ve birkaç aded mukāta'aya hâsıl kayd olunmağla sâlifü’z-zikr aşâyir kangı mukāta'a dâhilinde olduğunun sıhhati ma'lûm olamadı̆̆ı Başmuhâsebe defterhâne-yi 'âmiremden der-kenâr olunmağla bu sûretde zikr olunan aşîretler öteden berü kang1 mukāta'a tarafindan zabt ve hâsılât ve rüsûmâtı ne tarafdan ahz ü kabz olunu gelmiş ise ol vech ile zabt ü rabt ve hasılât ve rüsûmâtı ahz ü kabz olunub hilâf-1 şürût ve mugâyir-i kadîm hareketden mübâ'adet ve mahallinde sahte berât ve fermân sûreti ibrâz eden ma'rifet-i şer ve sen ki mütesellim-i ileyhsin ma'rifetinle ahz ve yedinde olan sûretler ile ma'an Der-sa'âdetime ihzâr olunmak fermânım olmağın bâ-takrir işbu emr-i celilü'l-kadrim ısdâr ve ( ～） ile irsâl olmuşdur. İmdi vusûlünde keyfiyet ma'lûmum oldukda zikr olunan aşîretler öteden berü kang1 mukāta'a tarafindan zabt ve hasılât ve rüsûmâtı ne tarafdan ahz ü kabz olunugelmiş ise yine ol vech ile zabt ü rabt ve has1lât ve rüsûmâtını ahz ü kabz etdirüb hilâf-1 şürût ve mugâyir-i kadîm hareketden mübâ'adet ve mahallinde sahte berât ve fermân sûreti ibrâz eden her kim ise ma'rifet-i şer' ve ma 'rifetinle ahz ve yedinde olan sûretler ile ma'an Der-'aliyyeme ihzâr olmasına mezîd-i ihtimam ü dikkat esnâ-yı râhda firâr eylemekden mübâ'adet eyleyesin ve sen ki kâdî-i mûmâ ileyhsin sen dahi mûcib-i emr-i şerîfimle 'amel ü hareket eyleme ${ }^{67}$ ( ) vardıkda bu bâbda vech-i meşrûh üzere şeref-yâfte-i sudûr olan işbu emr-i şerîf-i 'âlîşân-1 vâcibü'l-imtisâl ve lâzımü'l-imtisâlimin mazmûn-1 münîfi üzere 'amel idesiz. Şöyle bilesiz 'alâmet-i şerîfe i'timâd kılasız.

Tahrîren fi'l-yevmi's-sitte ve'l-'1şrîn Cemaziye'l-ahir sene semâne ve mi'eteyn ve elf. Be makām-1 Kostantiniyye ${ }^{68}$

66 Satır başında bir kelime eksiktir.

67 Bundan sonraki kısım bilinmeyen bir kimse tarafından karalanarak satırın boşluk kısmına Ferman 13 yazılmiştır.

68 Tarih ve mahall-i tahrîr kısmı mürekkep lekesinden dolayı net olarak okunamamıştır. 
Sira No : : 16

Belge No : Adana Ş.S. 62, img. 4, sayfa 32 belge 77-78

Tarih $\quad$ : 1 R $1209 / 26.10 .1794$

Konu : Hasan Paşazâde Ahmed Bey ve Mehmed Bey ve Mustafa Bey'in amcazâdeleri Hüseyin Efendizâde Es-seyyid İshak Efendi'ye verdikleri toplam 4.248 guruşun taraflarına iade talepleri

Medine-i Adana sükkânından Hasanpaşazâde Ahmed Bey ve Mehmed Bey ve Mustafa Bey nâmûn kimesneler meclis-i şer'-i hatîr-i lâzımu't-tevkirde ammizâdeleri işbu bâ'isu haze'l-kitab El-hâcc Hüseyin Efendizâde Es-seyyid İshak Efendi mahzarında şöyle 1krâr-1 tamm ve takrîr-i kelâm ederler ki:

Bundan akdem mütevvefâ pederlerimiz Abdullah Paşa ve el-Hâcc Ali Bey hâl-i hayâtlarında mûmâ ileyh İshak Efendi’ye i'ta eyledikleri on kantar koza baha ve dört yüz guruş ve Gerdan timârı iltizamı akçasından bin guruş ve küre akçasından yüz elli beş guruş ve katırcıdan otuz üç guruş ve deveciden otuz guruş ve kapukethüdâsı Çeprâsi damadı mütevvefâ Süleyman Efendi'den ahz edüb bizim edâ eylediğimiz yüz guruş ve asitâne-i aliyyeye 'azimetimiz esnâsında Karsandıŏlu İsmail Ağa'dan ahz edüb ma'lûmu'l-esâmî kesâna harc-1 râh ve mesârif nâmıyla fuzûlî telef ve izâ'a edüb ba'dehu bizim edâ eylediğimiz iki bin beş yüz guruş ve pirinç bahasından otuz guruş ile cem'an dört bin iki yüz kırk sekiz guruş alacak hakkımız olmağla defa 'atla mutālebe eylediğimizde edâda mümâna at ve muhâlefet eylediğine binâ'en bâ-arzıhal istid'a edüb isdâr etdirdiğimiz işbu emr-i celilü'ş-şân mûcebince mebâliğ-i mezkûrun efendi-i mûmâ ileyhden tamâmen ve kâmilen ahz ü tahsîli ve bizlere edâ ve teslîmi murâdımızdır dediklerinde emr-i celilü'ş-şân-1 mezkûr, efendi-i mûmâ ileyh muvâcehesinde feth ü kıra'at olunub gıbbe's-sû'al ol dahi cevâbında mütevvifiyân-1 mûmâ ileyhümâ mezkûr kozay1 bana hibe-i sahîha ile hîbe edüb ve bedel-i iltizâm içün dahi iki yüz kiyel şa'îr teslîm ve i'tâ eyledikden sonra fevt olmalarıyla mârrü'z-zikr muhallefât bahâsından zimmetimde bir para ve bir habbe olmadığından kat'ü’n-nazar Karsandıŏ̆lu'ndan me 'hûz akçayı dahi mîrûn-1 mûma ileyhimin vâlideleri beni tevkîl idüb rüfekâmız olan efendilerin harc-1 râhına i'tâ eyle deyü tenbîh ve mîrûn-1 mûmâ ileyhim edâ eylemedikleri sûretde bizler edâ ederiz deyü ta'ahhüd ve tekeffülleri hasebiyle ben dahi meblağ-1 mezbûr iki bin beş yüz guruşu ahz ve kendi umûrları zımnında Asitâne-i 'aliyyeye müterâhî olan efendilere ve sâ'ir kesâna harc-1 râh virüb ve ba'zı me'kûlât ve meşrûbâtlarına sarf eylemişidim deyü def'le mukâbele edicek münâza'a-i külliyeye bâ‘is olduğundan meyânelerine müslîmûn-1 muslihûn tavassut idüb "es-sulhü seyyidü'l-ahkâm” fehvâsı üzere bin yedi yüz elli guruş üzerine 'akd-1 inşâ-i sulh eylediklerinde tarafeynin dahi musâlaha-i mezkûru kabûl ve bedel-i sulh olan meblağ-1 mezbûr bin yedi yüz elli guruşu mîrûn-1 mûmâ ileyhüm tamâmen ve kâmilen edâ ve teslîm eyledikden sonra tarafeyn dahi meclis-i şer'e gelüb gerek koza baha ve iltizâm akçası ve gerek muhallefât bahâsı ve gerek Karsandıoğlu'ndan me 'hûz mebâliğden efendi-i mûmâ ileyhin zimmetini ibrâ‘-i 'âmm-1 
râfi'ü'l-hısâm ile ibrâ ve 1skāt-1 hakk eyledik min ba'd husûs-1 mezkûra müte‘allik da'vâ ve nizâ'‘mız zuhûr ider ise makbûle ve mesmû'a olmasun didiklerinde gıbbe’t-tasdîki'ş-şer'i mâ vaka'a bi't-taleb ketb olundu.

Hurrire fi gurre-i Rebî‘i’l-ahir sene tis‘a ve mi’eteyn ve elf. (1 R 1209 / 10 Ekim 1794)

Şuhûdü'l-hâl

Hâlen me'zûn-1 bi’l-iftâ fazîletlü Es-seyyid El-hâcc Ahmed Efendi

Kā‘immakām-1 nakîbü’l-eşrâf Es-seyyid El-hâcc Yusuf Efendi

Serdâr-1 Adana Çukadârzâde Abdulgani Ağa

Ateşî Es-Seyyid Ali Efendi

Miralay hâlen Es-Seyyid Mahmud Bey

Miralay sâbıkan Es-Seyyid Halil Bey

Kâtib-i mahkeme Durmuş Ali Efendi

Kâtib Es-Seyyid Ali Efendi

Avcızâde Ebubekir Ağa

Ser muhzırân Es-Seyyid El-hâcc Ali Ağa

Mustafa tâbi`-i Mîralay Halil Bey

Ali tâbi‘-i Mîralay Mahmud Bey

Şeyh-i hallâcân Halil Ağa ve gayruhum

\begin{tabular}{|l|c|}
\hline & Guruş \\
\hline Pederlerimiz hayâtda iken i'tâ eyledikleri on kantar koza bahâ ki kırkar guruşdan cem‘an & 0400 \\
\hline $\begin{array}{l}\text { Gerdan timârının bedel-i iltizâm akçasından bin yüz doksan sekiz senesinde temessük mû- } \\
\text { cebince }\end{array}$ & 1000 \\
\hline Ba‘de vefâtihümâ küre akçasından & 0155 \\
\hline Yine ba'de vefâtihümâ katırcıdan me'hûz & 0033 \\
\hline Deveciden me'hûz & 0030 \\
\hline & 1618 \\
\hline $\begin{array}{l}\text { Âsitâne-i ‘Aliyye’ye 'azîmetimiz esnâsında İsmail Ağa nâm Karsandızâde’den fuzûlî ahz } \\
\text { ve telef idüb ba'dehu bizim edâ eylediğimiz }\end{array}$ & 2500 \\
\hline Çaprasî Dâmâdı Süleyman Efendi'den ahz ve bizim edâ eylediğimiz & 0100 \\
\hline Ve pirinç bahâsından zimmetine geçen & 0030 \\
\hline $\begin{array}{l}\text { Cem‘an dört bin iki yüz kırk sekiz guruş mutālebemiz bin yedi yüz elli guruşa ibrâ olun- } \\
\text { muşdur. Sahh }\end{array}$ & 4248 \\
\hline
\end{tabular}


Sira No $: 17$

Belge No : Adana Ş.S. 62, img. 4, sayfa 33, belge 79

Tarih $\quad$ : 1 RA $1209 / 26.09 .1794$

Konu : Hasanpaşazâde Ahmed Bey, Mehmed Bey ve Mustafa Bey’in pederleri müteveffa El-hâcc Ali Bey ve Abdullah Paşa'nın muhallefatından kalan 4248 guruşun amcaları Es-seyyid İshak Efendi'de kaldığı ve bu meblağdan 1750 guruşu aldıktan sonra geriye kalan 750 guruşu da mahkeme önünde aldıkları hakkında.

Bâ‘is-i tahvîl-i tahrîr-i hurûf-ı hâlâs oldur ki:

İşbu bin iki yüz dokuz senesi mâh-1 Rebî‘ü’l-âhiri gurresinde bundan akdem müteveffiyân pederlerimiz Hasanpaşazâdeler El-hâcc Ali Bey ve Abdullah Paşa hâl-i hayâtlarında işbu dârende-i tahvîl 'ammîzâdemiz fazîletlü Es-seyyid İshak Efendi hazretlerine i'tâ eyledikleri ve ba'de vefâtihümâ muhallefâtlarından yine efendi-i mûmâ ileyhin ahz ve kendi umûruna ve sâ'irlere fuzûlî i'tâ ve telef eylediği mebâliğ-i ma'lûmü'l-mikdâr ki bâlâda zikr ü beyân ve tasrîh ü 'ayân olduğu vech üzere min haysü'l-mecmû' dört bin iki yüz kırk sekiz guruşu bâlâsındaki 1sdâr itdirdiğimiz bir kıt'a emr-i celîlü’ş-şân mûcebince huzûr-1 şer'-i şerîfde da'vâ ve mutâlebe eylediğimizde miyânemizde münâza'a-i küllî hâsıl olub ba'dehu Müslimûn-i muslihûn tavassut ve bin yedi yüz elli guruş üzerine 'akd-1 inşâ-i sulh eylediklerinde bizler dahi "Es-sulhü seyyidü'l-ahkâm ve es-sulhü 'akd yerfe'u'n-nizâ' fehvâs1 üzere sulh-1 mezbûru kabûl ve bedel-i sulh olan bin yedi yüz elli guruşu meclis-i şer'de efendi-i mûmâ ileyh hazretleri yedinden tamâmen ve kâmilen her birlerimiz hisselerimizi ahz ü kabz eylediğimizden sonra müdde'âmız olan husûs-1 mezkûra müte'allık 'âmme-i de'âvî ve mutâlebât ve kâffe-i eymân ve muhâsamâtdan her birlerimiz efendi-i mûmâ ileyhin zimmetini ibrâ-i 'âmm-1 râfi 'ü'l-hisâm ile ibrâ ve 1skāt-1 hakk eylediğimize binâ'en min ba'd husûs-1 mezbûra müte'allık da'vâ ve nizâ'mız zuhûr ider ise lede'l-hükkâmi'l-kirâm makbûle ve mesmû'a olmasun içün işbu ibrâznâme tahrîr ve li-ecli's-sened efendi-i mûmâ ileyh yedine i'tâ olundu. Gerekdir ki hîn-i hâcetde ibrâz ve ihticâc oluna ve's-selâm.

El-fakîr Mîr Ahmed Hasanpaşazâde hâlen

El-fakîr Mîr Mehmed Hasanpaşazâde hâlen

El-fakîr Mîr Mustafa Hasanpaşazâde hâlen 
Sira No : 18

Belge No : Adana Ş.S. 66, img. 12, sayfa 65, belge 79

Tarih : : 11-20 C 1209 / 03-11 Ocak 1795

Konu : Ramazanoğlu Vakfi'na ait Han-1 Cedid, Eğlemez Hanı, Çarşıhanı, Habbaz firını ve kahve dükkânlarının icarı hususunda Ramazanoğulları Vakfı mütevelli kaimmakamı Seyyid Halil Mahir'in alacakların tahsili hususunda kadıya müracaatı ve Hasanpaşazâde Ahmed ve Mehmed Bey'in de Eğlemez Hanı'nın 1208 yılı icaresi olarak 150 guruşun tahsili hakkında fermân.

Kıdvetü'l-kuzât ve'l-hükkâm ma‘denü'l-fazlı ve'l-kelâm Mevlânâ Adana kādısı zîde fazluhu ve k1dvetü’l-emâcid ve'l-a‘yân Adana mütesellimi( ) zîde mecdühu tevkī‘-i refî‘-i hümâyûn vâsil olıcak ma'lûm ola ki;

Sadr-1 a‘zam mektûbî hulefâsından kıdvetü’l-emâcid ve’l-a'yân Seyyid Halil Mâhir zîde mecdühunun Der-'aliyyeme takdîm eylediği 'arzıhâlinde Sadr-1 a'zam nezâretinde âsude evkâfdan mûmâ ileyhin bâ-berât-1 'âlî kā'immakām-1 mütevellîsi olduğu Ramazanzâde Vakfi'nın icâre-i vâhide ile îcâr olunagelen musakkafâtından iki yüz dört senesine mahsûben Adana'da vâk1' Hân-1 Cedîd icâresi olmak üzere kazâ-i mezbûrda sâkin Yeğenzâde Seyyid Mehmed Said ve Hacı Beyzâde Mustafa Bey dimekle 'arîf kimesneler zimmetlerinde sekiz yüz ve iki yüz beş ve altı ve yedi ve sekiz senelerine mahsûben dahî yine hân-1 mezkûr icâresi bakāyâsından yine merkûmân zimmetlerinde sekiz yüz cem'an bin altı yüz guruş ve yine kazâ-i merkûmede kâ'in Eğlemez Hânı iki yüz sekiz senesi icâresinden Abdullah Paşazâde Ahmed Bey ve Mehmed Bey nâm kimesneler zimmetlerinde yüz elli guruş ve Çarşuhânı icâresinden Çukadârzâde Abdülganî Bey nâm kimesne zimmetinde iki yüz dört ve beş senelerinden bin sekiz yüz elli beş ve Silahşorân-1 Hâssadan Adana Mütesellimi sâbık Hazînedâr Mehmed zîde mecdühu zimmetinde altı ve yedi ve sekiz senelerine mahsûben Çarşu Hânı icârâtından üç bin yedi yüz elli ve Ahmed Bey ve Mehmed Bey nâm kimesneler ile Elif nâm hâtun zimmetlerinde habbâz firunı ve ma'lûmü'l-'aded kahve dükkânları icârâtından yedi ve sekiz senelerine mahsûben üç yüz elli ve Külahçı Hacı Mustafa zevcesi demekle 'arîfe Zeliha nâm hâtun zimmetinde kahve dükkânı icâresinden dört ve beş ve altı ve yedi ve sekiz senelerinden doksan ve Vâlî Sarâyı kirâsı olmak üzere altı ve yedi ve sekiz senelerine mahsûben ahâlîden ma'lûmü'l-esâmî kesân zimmetlerinde üç senelik bin elli ve Kara Hasanoğulları demekle meşhûr kimesneler zimmetinde ma'lûmü'l-'aded dekâkîn icârâtından üç yüz cem'an dokuz bin yüz kırk beş guruş emvâl-i vakf tecemmu' ve terâküm eylediği ve lede'l-mutālebe edâdan imtinâ' eyledikleri ve ashâb-1 vezâyifin idâresi ve cevâmi'-i vakfın masârıfı bu makûle hâsılâtın mahallerinden tahsîline menût idüği beyânıyla Sadr-1 a'zam çukadârlarından kıdvetü'l-emâsil ve'l-akrân Abdullah zîde kadrühu mübâşeretiyle sâlifü’z-zikr dokuz yüz kırk beş guruşu merkûmlardan tamâmen tahsîl ve tarafından kabzına me'mûra teslîm ettirilmek bâbında emr-i şerifim sudûrunu istid'â eylediğine binâ'en siz ki mevlânâ ve mütesellim-i mûmâ ileyhümâsız vech-i meşrûh 
üzere çukadâr-1 mûmâ ileyh mübâş̧eretiyle mahallinde şer'le ru'yet ve îcâb edenlerden tahsîl ve kabzına me'mûra teslîm ettirilmek fermânım olmağın imdi siz ki mevlânâ ve mütesellim-i mûmâ ileyhümâsız ma'rifetiniz ve mübâş̧ir-i mûmâ ileyh ma'rifetiyle merkûmûnu mahallinde huzûr-1 şer'a ihzâr ve ber vech-i muharrer şer'le ru'yet ve lede's-sübût sâlifü'z-zikr icârât-1 vakfi tamâmen ve kâmilen tahsîl ve mûmâ ileyhin tarafindan kabzına me'mûra edâ ve teslîme mübâderet ve hilâfindan mücânebet eylemeniz bâbında fermân-1 'âlî-şânım sâdır olmuşdur. Buyurdum ki;

Vusûl buldukda bu bâbda vech-i meşrûh üzere şeref-yâfte-i sudûr olan fermân-1 vâcibü'l-ittibâ‘ ve lâzımü'l-imtisâlimin mazmûn-1 itâ'at-makrûnuyla 'amel ü hareket ve hilâfindan hazer ü mücânebet eyleyesiz. Şöyle bilesiz 'alâmet-i şerîfe i'timâd kılasız. Tahrîren fî evâsıtı şehri Cemâziye'l-âhir sene tis‘a ve mi'teyn ve elf.

Bi-makāmı Kostantiniyyeti'l-mahrûse 
Sira No : : 19

Belge No : Adana Ş.S. 55, img. 9, sayfa 16, belge 220

Tarih : Gurre M 1210 (18 Temmuz 1795)

Konu : : Ateş Efendi'den öşür bedeli olarak 180 guruşun alınıp mübâşirine teslim edildiğine dair.

Bâ'is-i tahvîl oldur ki:

İşbu bin iki yüz on senesine mahsûben Adana'da vâk1' İki Kenisâ Mukāta'a mülhakātından Küçük Dikili karyesinde olan Ateş Efendi'nin zirâ‘at eylediği şa'îr ve koza ve küncü69 'öşrü bahâsı ba 'de't-terâfu' yüz altmış guruş idüb ve yirmi guruş dahi Kılınçoğlu öşründen cem 'an yüz seksen guruşun bâ-fermân-1 'âlî tahsîline ve mübâşiri çukadâr-1 hazret-i defterdârî El-hâcc Mehmed Ağa'ya teslîmine me'mûr olduğumuza binâ'en meblağ-1 mezbûru tamâmen efendi-i mûmâ ileyh yedinden ahz ü kabz olunub mübâşir-i merkûma teslîm olunmağla sened olunmak içün yedine işbu memhûr tahvîl virilmişdir. Vakt-i hâcetde ibrâz oluna ve's-selâm. Fî Gurre-i M sene 210

El-fakîr Mîr Ahmed Hasanpaşazâde mütesellim-i Adana hâlen. 
Sira No : $: 20$

Belge No : Adana Ş.S. 64, img. 60, sayfa 71. Belge 160

Tarih : :25 B $1210 / 11$ Ağustos 1795

Konu : Hasanpaşazâde Ahmed Bey, Mehmed Bey ve Mustafa Bey'in 'uhdelerinde olan Cemâ'athâ-i Yörügân-1 Adana, Tarsus ve Sis Mukāta'alarının 1209 senesine mahsûben emvâli olan 10.077 guruşun tahsil edildiğine dair.

Bâ'is-i hurûf oldur ki:

Adana sâkinlerinden Hasanpaşazâde Ahmed Bey ve Mehmed Bey ve Mustafa Bey ber vech-i mâlikâne iştirâken 'uhdelerinde olan cemâ'athâ-i Yörügân-1 Adana ve Tarsus ve Sis Mukāta'asının bin iki yüz dokuz senesine mahsûben ma'a tefâvüd-i şemsiyye iktizâ eden emvâl on bin yüz yetmiş yedi buçuk guruş olub Der-'aliyye'den matlûb buyurulmağla mübâşeretim ve kabzina me'mûr olduğum hasebiyle sene-i mezkûr mâl-1 mîrîsi olan meblağ-1 mezkûru mîr-i mûmâ ileyhim yedlerinden tamâmen ve kâmilen ahz ü kabz olunmağla ahz olunduğunu müş 'ir yedlerine işbu memhûr tahvîl virilmişdir. Vakt-i hâcetde sened olub ihticâc oluna.

Hurrire fî 25 Recebü'l-mürecceb sene 1210 (11.08.1795)

El-Fakîr Ebu Bekir Mehter tâbi'-i defterdâr-1 şıkk-1 evvel hâlen 
Sira No : 21

Belge No : Adana Ş.S. 56, img. 18, sayfa 34, belge 40

Tarih : :04 S $1210 / 20$ Ağustos 1795

Konu : Yörügân-1 Adana, Tarsus ve Tevâbi ‘i Mukāta‘alarının 1210 ve 1211 senelerine mahsûben taksît akçası olan 5.455 guruşun toplanılarak İstanbul'a gönderilmesine dair fermân.

Kıdvetü'l-kuzât ve'l-hükkâm ma“denü'l-fazlı ve'l-kelâm Mevlânâ Adana kâdîsı zîde fazluhu ve kıdvetü'l-emacid ve'l-a‘yân Adana Mütesellimi Ahmed Bey zîde mecdühu ve kıdvetü'l-emâsil ve'l-akrân bu husûsa mübâşir ta ‘yîn olunan sadr-1 a'zamım ikinci çukadârı İbrahim zîde kadruhu tevkî'-i refî‘i hümâyûn vâsıl olıcak ma‘lûm ola ki:

Sen ki mütesellim-i mûmâ ileyhsin ber vech-i iştirâk mâlikâne 'uhdende olan Yörügân-1 Adana ve Tarsus ve Tevâbi'i Mukāta'asının bin iki yüz on ve on bir senelerine mahsûben taksît akçası bi-mennihi ta‘âlâ işbu sene-i mübâreke Şa‘bânında divân-1 müşeyyedü'l-erkân-1 hüsrevânemde ihrâcı müsammem olan kapum kullarının kısteyn mevâciblerine tertîb ve tahsîs k1lınmakdan nâşî ve kaleminden ihrâc ve derûn-1 emr-i şerîfime mevzû'an irsâl olunan sûret-i defterde tahrîr olunduğu üzere mukāta'a-i mezbûrenin taksît akçası olan ma'a harc-1 vezne beş bin dört yüz elli dört guruş ma'rifetin ve ma'rifet-i şer'le tedârük ve tahsîl ve mübâşir-i merkûma teslîmen bir an akdem Der-sa'âdetime irsâl ve tesyîre mezîd-i sa'y ü dikkat eylemen fermânım olmağın işbu emr-i 'âlîşânım ısdâr ve mübâşir-i merkûm ile irsâl olunmuşdur. İmdi vusûlünde bâlâda tahrîr ü beyân ve sûret-i defterde tasrîh ü 'ayân k1lındığı üzere mukāta'a-i mezkûrenin seneteyn-i mezbûreteyne mahsûben taksît akçası olan harc-1 vezne beş bin dört yüz elli dört guruş mevâcib-i mezkûreye tertîb olunmuş olmakdan nâşî bir gün evvel gelüb hazîne-i 'âmireme tesellümü matlûb-1 şâhânem idüğü ma'lûmun oldukda vürûd-1 emr-i şerîfimle meblağ-1 mezbûru ma'rifetin ve ma'rifet-i şer'le tamâmen tedârük ve 'alâ eyyi hâlin yerlü yerinden tahsîl ve mübâşir-i merkûm ile serî‘an ve 'âcilen Der-sa'âdetime irsâl ve hazîne-i 'âmireme teslime kemâl tekayyüd ü ihtimâm eyleyesin. Şöyle ki meblağ-1 mezbûrun bir gün evvel gelüb hazîne-i 'âmireme tesellümü matlûb olmağla meblağ-1 mezbûru ashâb-1 mukāta'adan ve mevcûd olmayanların mültezimlerinden ve anlar dahi bulunmadığı hâlde mukāta'adan kendülere 'â‘id hâsılâtdan vâzı'ü'l-yed olanlardan tahsîline müsâra'at ve muhâlefet ideri olur ise mukāta'aları üzerlerinden ref' olunmak içün 'arz ü i'lâma mübâderet eyleyesin ve sen ki mübâşir-i merkûmsun muktezâ-yı me'mûriyetin üzere meblağ-1 mezbûr beş bin dört yüz elli dört guruşu ber mûceb-i sûret-i defter mütesellim-i mûmâ ileyhin ma'rifeti ve ma'rifet-i şer' ve ma'rifet ve mübâşeretinle bi-eyyi hâlin tamâmen ve kâmilen tahsîl ve istishâb ve bir gün evvel getürüb hazîne-i 'âmireme teslîme mezîd-i sa'y ü gayret ve hilâf-1 rıâ tûl müddet meks ü tevakkufdan gâyetü'l-gâye hazer ü mücânebet eyleyesin ve sen ki kâdî-i mûmâ ileyhsin keyfiyet mantûk-1 emr-i münîfimden ma'lûmun oldukda mûcib ve muktezâsı üzere 'amel ü hareket ve hilâfından be-gâyet tevakkî ve mübâ'adet eylemen bâbında fermân-1 'âlîşânım sâdır olmuşdur. Buyurdum ki: 
Hükm-i şerîfimle ( ） vardıkda bu bâbda vech-i meşrûh üzere şeref-yâfte-i sudûr olan işbu emr-i şerîf-i celîlü'ş-şân-1 vâcibü'l-imtisâl ve lâzımü'l-ittibâ'1mın mazmûn-1 münîfi üzere 'âmil olub hilâfiyla vaz' ü hâlât vukû'undan be-gâyet tehâşî ve mübâ'adet eyleyesiz. Şöyle bilesiz 'alâmet-i şerîfe i'timâd kılasız. Tahrîren fi'l-yevmi'r-râbi' Saferi'l-hayr sene 'aşer ve mi'eteyn ve elf.

Bi-makāmı Kostantiniyyeti'l-mahrûse 
Sira No : 22

Belge No : Adana Ş.S. 48, img. 66, sayfa 128, belge 206

Tarih : Evail Safer $1210 /$ 17-26 Ağustos 1795

Konu : : Hüccâc-1 Müslimînin Adana’da geçerken güvenliğinin sağlanmasına dair fermân.

İftihârü'l-emâcid ve'l-ekârim câmi ‘u'l-mehâmid ve'l-mekârim el-muhtassu bi-mezîdi ‘inâyeti'l-meliki'd-dâ‘im Dergâh-1 Mu'allâm Kapucıbaşılarından Adana Mütesellimi Ahmed Bey dâme mecdühu tevkî‘-i refî'-i hümâyûn vâsıl olıcak ma'lûm ola ki:

Hüccâc-1 Müslimînin bi'l-emn ve's-selâme zehâb (ü) iyâbları husûsuna kemâl-i akdem ve ihtimâm olmak üzere mukaddemen hîn-i 'azimetlerinde evâmir-i şerîfimle cümleye tenbîh ü te'kîd olunmuşdu. El-hâletü hâzihi vakt-i 'avdetleri takrîb eylemek hasebiyle fevc fevc gelen hüccâc-1 hidâyet-minhâcın kemâl-i emn ü selâmetle imrâr ve vatanları îsâllerine saltanat-1 seniyyenin akdem umûrundan olmakdan nâşi ber vech-i muharrer vürûdûn iden hüccâc-i müslimînin Adana eyâleti dâhilinde âminen imrârları sen ki mütesellim-i mûmâ ileyhsin kat'an ${ }^{70}$ ve cezmen senden matlûb-1 mülûkânem olduğuna binâ'en 'avdet-i hüccâcdan mukaddem Adana eyâletiyle hem-hudûd olan Karaman vâlîsi düstûr-1 mükerrem müşîr-i mufahham nizâmü'l-'âlem vezirim paşa edâme Allâhu ta'âlâ iclâlehu ve sâ'ir zâbitân ile haberleşerek cânib-i cezâdan ric'at eden hüccâc-1 müslimîni kapun halk1 ve eyâlet-i Adana'nın harb ü darb erbâbını istishâb ile re's-i hudûd-1 Adana'dan istikbâl ve nihâyet-i hudûda dek sâlimen îsâl ve Karaman vâlîsi vezir-i müşârun ileyhin kethüdâsına teslîme sa'y-1 bî-hemâl eylemen fermânım olmağın te'kîden ve ihtimâmen hâssaten işbu emr-i alîşânım 1sdâr ve rikâb-1 hümâyûnum kā'immakāmı tatarlarından kıdvetü'l-emâsil ve'l-akrân El-hâcc Hüseyin zîde kadrühu ile irsâl olunmuşdur. İmdi yolların levs-i vücûd-1 habâset-alûd eşkıyâdan gereği gibi te'mîn ve tathîriyle ebnâ-i sebîlin ve bâ-husûs hüccâc-1 zevi'l-ibtihâcın kemâl-i emn ü selâmetiyle mürûrlarına sinîn-i sâbıkadan birkaç ziyâde ihtimâm ü dikkat olunmak murâd-ı mülûkânem idügü ma'lûmun oldukda bu def'a evkāt-1 sâ'ireye kıyâs olunmayub te'mîn-i turuk ü mesâlik esbâbının istihsâline mezîd-i sa'y ü gayret ederek ve levâzım-ı hazm ü ihtiyâta ri'âyet eyleyerek hüccâc-1 hidâyet-minhâcın avdetlerinde ber vech-i meşrûh Karaman vâlîsi vezir-i müşârun ileyh ve sâ'irleriyle haberleşerek mükemmel ve müretteb kapun halk1 ve eyâlet-i Adana'nın harb ü darb erbâbınn ${ }^{71}$ istishâb birle re's-i hudûd-1 Adana'dan istikbâl ve âminen ve sâlimen nihâyet-i hudûd-1 Adana'ya îsâl ve Karaman vâlîsi müşârun ileyhin kethüdâsına teslîme ve yolların gereği gibi te'mîniyle terfih-i ahvâl-1 hüccâc ve sâ'ir ebnâ-i sebîle sarf ü sa'y-1 makderet eyleyesin. Şöyle ki bu husûsu mukaddemce sana tenbîh ü te'kîdden maksûd asıl yolların eşkıyâdan te'mîn ü tathîri ve bâ-tahsîs hüccâc-1 müslimînin ve ebnâ-i sebîlin mashûben bi's-selâme imrârlarına ihtimâm ü dikkat eylemen irâdesine mebnî iken ma‘âze Allâhu ta‘âla bu emr-i ehemmin ednâ mertebe rehâvet ve tekâsül-i huluvverî sebebiyle eyâlet dâhilinde du-

70 Metinde (قطاعا ) şeklinde yazılmıştır.

71 Metinde iyâbını (إينى) şeklinde yazılmıştır. 
halâ-yı tarîk hüccâc-1 müslimine ve sâ'ire mârrîn ve âbirîne mikdâr-1 zerre îrâs-1 zarar ü ziyân eylemek ve yâhud esnâ-y1 râhda fukarâya zulm ü ta'addi olmak lâzım gelür ise özr ve illetin bir dürlü karîn-i sem'-i 1skâ olunmayub mazhar-1 eşedd-i 'ikâb ü 'itâb-1 mülûkânem olacağın muhakkak ve mukarrerdir. Âna göre mezîd-i basiret ü intibâh üzere hareket ve ser-i mû kusûr ü rehâvetden el-gâyetü'l-gâye hazer ü mücânebet eylemen bâbında fermân-1 âlisşânım sâdır olmuşdur. Buyurdum ki ( ） vusûl buldukda bu bâbda vech-i meşrûh üzere şeref-yâfte-i südûr eden fermân-1 vâcibü'l-ittibâ' ve lâzımü'l-imtisâlimin mazmûn-1 ita'ât-makrûnuyla 'amel ${ }^{72}$ ü hareket ve hilâfından ib'âd eyleyesin. Şöyle bilesin 'alâmet-i şerîfe i'timâd kılasın. Tahrîren evâ’il-i şehr-i Saferü'l-hayr sene seb'a 'aşer ve mi’eteyn ve elf.

Bi-makāmı Kostantiniyyeti'l-mahrûse 
Sira No : 23

Belge No : Adana Ş.S. 56, img. 04, sayfa 06, belge 68

Tarih : : 17 S $1210 / 02$ Eylül 1795

Konu : Ahmed, Mehmed ve Mustafa Beylerin mâlikane uhdelerinde olan Yörügân-1 Adana, Tarsus ve Tevâbi‘i Mukāta'aları'nın 1200 senesinden 1209 senesine gelince terâküm eden altı bin beş yüz elli altı buçuk guruşun tahsil edilip Sadr-1 a'zam İzzet Mehmed Paşa'nın hazinesine gönderilmesine dair fermân.

Emirü'l-ümerâi'l-kirâm kebîrü'l-küberâ'i'l-fihâm zu'l-kadri ve'l-ihtirâm sâhibü'l-'izzi ve'l-ihtişâm el-muhtassu bi-mezîdi inâyeti'l-meliki'l-a 'lâ Adana Beylerbeyisi Yusuf Paşa dâmet me‘âliyehu ve kıdvetü'l-kuzât ve'l-hükkâm ma‘denü’l-fezâ‘il ve'l-kelâm Adana ve Tarsus kâdîları zîde fazluhumâ ve kıdvetü'l-emâcid ve'l-akrân bu husûsa mübâşir ta ‘yîn olunan sadr-1 a'zamım çukadârlarından kıdvetü'l-emâsil ve'-1 akrân Osman zîde kadrühu tevkî‘-i refî‘-i hümâyûn vâsıl olıcak ma’lûm ola ki:

Zamân-1 zabtı Mart ibtidâsından olub Adana sâkinlerinden Karslızâde Hasan Paşa hafîdleri Ahmed Bey ve Mehmed Bey ve Mustafa Bey nâm kimesnelerin ber vech-i mâlikâne 'uhdelerinde olan Yörügân-1 Livâ-i Adana ve Tarsus ve Tevâbi'i Mukāta'ası'nın bin iki yüz senesinden iki yüz dokuz senesine gelince ber mu'tâd-1 kadîm iktizâ eden kalemiyyelerinden düstûr-1 ekrem ve mu'azzam müşîr-i mufahham ve muhterem nizâm-1 menâzımü'l-ümem hâlen sadr-1 a'zamım sütîde-şiyem ve vekîl-i mutlak-1 sadâkat-'alemim olan İzzet Mehmed Paşa edâme Allâhu ta'âlâ iclâlehu ve zâ‘ifun bi’l-'izzi ve’t-temkîn iktidârehu ve ikbâlehunun hissesine isâbet eden ma'a harc-1 aklâm altı bin beş yüz elli altı buçuk guruş kırk akça kalemiyye akçalarını merkûmlardan tahsîl ve müşârün ileyhin hazînesine teslîmi mühimm ve muktezî olmağın hâsseten işbu emr-i celîlü'l-kadrım ısdâr ve ( ） ile irsâl olunmuşdur. İmdi vusûlünde siz ki mîr-mîrân ve kâdîlar-1 mûmâ ileyhimsiz derûn-1 emr-i şerîfime mevzû'an irsâl olunan mümzâ sûret-i defterde tasrîh olunduğu üzere sinîn-i merkûmeye mahsûben iktizâ iden mezkûrü'l-mikdâr kalemiyye akçasını merkûmlardan ve mevcûd bulunmayanların taraflarından zabt iden voyvoda ve mültezimlerden ma'rifet-i şer' ve mübâşir-i merkûm ma'rifetiyle 'alâ eyyi hâlin tahsîl ve mübâşir-i merkûma teslîm birle mahalline kayd olunmak içün ma'mûlün bih olmak üzere memhûr temessük aldırub bir an akdem sadr-1 a'zamım müşârun ileyhin hazînesine irsâl ü isâle mezîd-i ihtimâm ü dikkat eyleyesiz Şöyle ki bu makûle kalemiyye akçasının 'ukde-i te'hîre düçâr olduğuna kat'an rızâ-yı hümâyûnum olmamağla mebâliğ-i mezbûrun tahsîlinde tereddüd ve muhâlefet ederi olur ise mâlikâneleri üzerlerinden ref' ve mezâda kā'imeleri virileceğini gûş-1 hûşlarına ilkâ ederek bir gün evvel tahsîl ve teslîmine ikdâm eyleyesiz ve sen ki mübâşir-i merkûmsun yedine verilen mümzâ sûret-i defter mûcebince ol mikdâr kalemiyye akçasını ma'rifet-i şer' ve ma'rifet ve mübâşeretinle 'alâ eyyi hâlin îcâb ü iktizâ edenlerden tahsîl ve istishâb ve 'icâleten ve müsâra'aten Der-'aliyye'me getürüb müşârün ileyhin hazînesine teslîme sür'at ü şitâb eylemen bâbında fermân-1 'âlîşânım sâdır olmuşdur. Buyurdum ki: 
Hükm-i şerîfimle ( vardıkda bu bâbda vehc-i meşrûh üzere şeref-yâfte-i sudûr olan işbu emr-i şerîf-i celîlü'ş-şân-1 vâcibü'l-imtisâl ve lâzımü’l-ittibâ'1mın mazmûn-1 itâ'at-makrûnuyla 'âmil olasız. Şöyle bilesiz 'alâmet-i şerîfe i'timâd kılasız. Tahrîren fi'l-yevmi’s-sâbi' 'aşeri Safer sene 'aşer ve mi 'eteyn ve elf.

Bi-makāmı Kostantiniyyeti'l-mahrûse 
Sira No : 24

Belge No : Adana Ş.S. 64, img. 65, sayfa 61, belge 177

Tarih $\quad: 15$ C $1210 / 27$ Aralı 1795

Konu : Kerimli aşireti Boybeyi Kerimzâde Süleyman Ağa'dan 1207 ve 1208 senelerine mahsuben devlet geliri olarak 4500 guruşun Kozanzâde Yusuf Ağa aracılığıyla tahsil edildiğine dâir

Bâ'is-i tahvîl oldur ki

Ber vech-i mâlikâne iştirâken 'uhdemiz(de) olan cemâ'athâ-yı yörügân-1 Adana ve Tarsus ve Sis Mukāta'asını bin iki yüz yedi ve sekiz senelerine mahsûben sahte berât ile sâbık kilârî-i hâssa Mustafa Ağa "mâlikâne-i mezbûr benim üzerime geçik" deyü yörügân cemâ'atlerinden Kerimli 'aşîretinden sene-i sâbıkası üzere iki senelik mâl-1 mîrîleri olan dört bin beş yüz guruşu 'aşîret-i mezbûr boybeyisi Kerîmzâde sa'âdetlü Süleyman Ağa'dan ahz ü kabz edüb Kozanzâde Yusuf Ağa ma'rifetiyle tahsîl ve yedlerine edâ ve tesellümlerini müş‘ir tahvîl i’tâ itmekle gerekdir ki iki yüz yedi ve sekiz seneleri mâl-1 mîrîsinden Kerîmli 'aşîretlerinde bir para kalmayub merkûm Kilârî Mustafa Ağa tarafina virildiğine bizim dahi 'ilmimiz lâhık olmağın yedlerine tarafimızdan dahi işbu tahvîl tahrîr ve i'tâ olundu. Gerekdir ki vakt-i hacette ibrâz oluna ve's-selâm. Fî 15 Cemâziye'l-ahir sene 1210

İşbu tahvîlden murâd 'aşîret-i mezbûr yedinde olan Kilârî Mustafa Ağa'nın tahvîli ahz ve der-'aliyyeye irsâl olunmağla mukābelesinde sened içün tarafımızdan 'aşîret yedine işbu tahrîr virilmişdir. Sahn.

El-fakîr Mîr Ahmed Hasanpaşazâde

El-fakîr Mîr Mehmed Hasanpaşazâde

El-fakîr Mîr Mustafa (bin) Hacı (Ali) Bey 
Sira No : $: 25$

Belge No : Adana Ş.S. 56, img. 31, sayfa 73, belge 5

Tarih : : 07 Ş $1210 / 16$ Şubat 1796

Konu : Ahmed Bey'den Adana cizyesinden arta kalan 2500 guruş tahsil edilmesine dair

Bâ‘is-i tahvîl-i tastîr-i hurûf oldur ki

İşbu bin iki yüz on bir senesi mâh-1 Şabânü'l-mu'azzamın yedinci gününde sâbık Adana Mütesellimi Hasanpaşazâde necâbetlü Ahmed Bey hazretlerinin sene-i mezbûra mahsûben bâemr-i 'âlî 'uhdesinde olan eyâlet-i Adana cizyesinin mâl-1 bekāyāsını bâ-emr-i 'alî ahz u kabza mübâşeretim hasebiyle işbu def'a dört kıt'a poliçe temessükâtı mûcebince beş yüz guruşdan cem'ân iki bin guruş ahz ü kabz ve devletlü defterdâr-1 şıkk-1 evvel efendimizin hazîne-i 'aliyyelerine teslîm olunmak içün irsâl eylediğimi müş 'ir işbu tahvîl tahrîr ve mîr-i mûmâ ileyh yedine i'tâ olundu. Gerekdir ki vakt-i hâcetde ibrâz ve ihticâc oluna ve's-selâm. Fî 7 Ş sene 1210 El-fakîr Hüseyin Çukadâr-1 Sadr-1 a'zam 
Sira No : 26

Belge No : Adana Ş.S. 56, img. 31, sayfa 73, belge 4

Tarih : :21 Ramazan 1210/30 Mart 1796

Konu : Ahmed Bey tarafindan Adana Serdarı Mustafa A ğa’ya verilen mahkemede bütün ulema ve eşrâf huzurunda canına ve malına bir saldırı olmayacağına dair verilen teminat hüccetidir.

Hâlen eyâlet-i Adana Mütesellimi Hasanpaşazâde sa'âdetlü Ahmed Bey Hazretleri meclis-i şer'de bi'l-cümle 'ulemâ ve sülehâ-i e'imme ve hutebâ ve a'yân ve eşrâf ve vazî̀ ü refî‘ bi-ecma‘ihim hâzır oldukları hâlde hâlen Adana serdârı ser-turnayî-i dergâh-1 'alî izzetlü Hacı Mustafa Ağa mahzarında şöyle takrîr-i kelâm ve ta'ahhüd-i tâmm eder ki mûmâ ileyh Mustafa Ağa ez kadîm 'eban ve an ceddin bi'l-cümle hizmetimizde sadâkat ve istikāmet üzere olub ve hâlen Adana serdârı olmağla mukaddem yedinde olan hüccet-i şer'iyye mûcebince a’yân-1 belde olub ve müceddeden cümle ma'rifetiyle diğer hüccet virilüb a'yânlığı umûrunda kıyâm ve bi'l-ittifâk amel ü hareket olunub ve tarafımızdan her vechile kendüye emniyet-i tâmmeyi hâvî mâlına ve canına ve 1yâl ü etbâ'‘na su-i kasd etmemek üzere ahd-1 misâk eylediğimiz sicill-i mahfûza kayd olunsun didikde ol dahi cümle muvâcehesinde ber vech-i meşrûh amel ü harekete müte'ahhid ve bu vechile hâlen me'zûn-1 bi'l-iftâ fazîletlü Es-seyyid İshak Efendi ve sâbık mehâbetlü Es-seyyid El-hacc Ahmed Efendi ve esbâk Hisarzâde Ömer Efendi ve yine esbâk mehâbetlü Es-seyyid Mustafa Efendi ve müderrisîn-i kirâmdan Es-seyyid Yahya Efendi ve kā'immakām-1 nakîbü'l-eşrâf Es-seyyid El-hâcc Yusuf Efendi ve sâ'ir efendiler ve ağavâtdan mûmâ ileyh Hacı Mustafa Ağa’ya kefil oldukları işbu hüccete kayd şod. Fî 21 Ramazan sene 210 . 
Sira No : $: 27$

Belge No : Adana Ş.S. 56, img. 12, sayfa 22-23, belge 53

Tarih $\quad: 14$ N $1210 / 23$ Mart 1796

Konu : Sabık Adana Mütesellimi Karcı Mehmet'in idamından sonra mallarının hazineye gönderilmesi emrine rağmen Sabık Adana Beylerbeyi Yusuf Paşa'nın maktulun mallarını ve hanımının eşyasını usulsüz olarak zabt ettiğinden dolayı yerine atanan Mehmed Paşa'nın maktul Karcı Mehmed'in eşinin mallarının geri vermesine dair ferman.

Kıdvetü'l-kuzât ve'l-hükkâm ma'denü'l-fazlı ve'l-kelâm Mevlânâ Adana kâdîsı zîde fazluhu ve k1dvetü’l-emâcid ve'l-a‘yân Adana Mütesellimi Ahmed Bey zîde mecdühu ve mefâhirü'l-emâsil ve'l-akrân maktûl Karcı Mehmed'in muhallefâtı zabtına me'mûriyet ile el-yevm ol cânibde olan sadr-1 a'zamım çukadârlarından İbrahim ve Abdullah ve a'yân ve zâbıtân vesâ'ir iş erleri tevkî'-i refî'-i hümâyûn vâsıl olıcak ma'lûm ola ki:

Bundan akdem katîlen fevt olan Adana mütesellimi sâbık merkûm Karcı Mehmed'in iki yüz sekiz ve dokuz senelerine mahsûben cibâyeti 'uhdesinde olan eyâlet-i Adana cizyesi mâllarından cânib-i mîrîye yirmi yedi bin yedi yüz kırk beş buçuk guruş zimmeti olduğundan gayrı iltizâmen 'uhdesinde olan resm-i ispençe-i Adana ve memlaha ve mukāta ât-1 sâ'ire bedel-i iltizâmâtından gayr-1 ez teslîmât hâcegân-1 divân-1 hümâyûnumdan Der-'aliyyemde mühimmât nâzırı olan Hasan zîde mecdühu tarafina bi’t-temessük ve defter dokuz bin guruşdan mütecâviz deyni olduğundan bi'l-cümle emvâl ü eşyâ ve emlâk ve hayvânât ve der-mahzen olan tuz ve hınta ve şa 'îr ve koza ve sâ'iresi mübâşirân-1 merkûmân ma'rifetleriyle cânib-i mîrîden zabt ve tahrîr ve eşya-yı nefisesi 'aynen ve sakîlesi ol tarafda bi’l-müzâyede değer bahâlarıyla tâliblerine fürûht ve hâsıl olan esmânı deyü mîrîye ve sâ‘iresine mahsûben Der-sa‘âdetime irsâl ü îsâl olunmak bâbında Adana Beylerbeyisi sâbık Yusuf Paşa dâme ikbâ(lühu)ya ve Adana kâdîsına ve mübâşirân-1 merkûmâna hitâben bi'd-def'ât evâmir-i 'aliyyem 1sdâr ve irsâl olunub ancak mîr-mîrân-1 mûmâ ileyh maktûl-1 merkûmûn eşyâ-yı nefîsi ile memlû sandıklarını ve nükûd ve sâ'iresini kendüye temlîk olunmuş gibi cebren ahz eylediğinden gayrı maktûl-1 merkûmun zevcesinin dahi eşyâ ve halısını ahz ü kabz eylediği mütevâtiren tahakkuk ve şimdiye değin bir akça ve bir habbe irsâl eylemeyüb mübâşirân-1 merkûmu dahi müddet-i medîde habs gûne ol tarafda meks ile tevkîf itmekden nâşî bu def'a mîr-mîrân-1 mûmâ ileyhin eyâlet-i merkûmeden 'azli ve âherin nasbı lâzım geldiğinden 'azl olunub eyâlet-i mezkûre mîr-mîrân-1 kirâmdan hâlen İsmail muhâfizı Mehmed Paşa dâme ikbâlühuya tevcîh olunmuş olmağla siz ki kâdî ve mütesellim-i mûmâ ileyhümasız mûmâ ileyh Yusuf Paşa maktûl-1 merkûm Karc1 Mehmed'in emvâl ü eşyâ-yı nefise ve zehâyir ve hayvânât-1 sâ'iresinden ve zevcesinin eşyâ ve halısından sırren ve 'alenen her ne ki ahz ü kabz ve zabt eylemiş ise bir helâl ve bir habbesi girüye kalmayarak ma'rifetiniz ve ma'rifet-i şer' ve mübâşirân-1 merkûmân ma'rifetleri ve cümle ittifâkıyla cümlesini zâhire ihrâc ve zevce-i mezbûrenin eşyâsını kendüsüne teslîm ve mâ‘adâsını cânib-i mîrîçün istirdâd ve ahz ü kabz ve mahall-1 me'mene vaz' ve hıfz ve mu- 
kaddem fermânım olduğu üzere eşyâ-yı nefiseyi 'aynen ve eşyâ-yı sakîle ve hubûbât ve tuz ve koza ve hayvânât ve emlâkini değer bahâlarıyla bi'l-müzâyede tâliblerine fürûht ve hâsıl olan esmânını zimmet-i mîrîye ve düyûn-1 sâ'iresine mahsûben Der-sa'âdetime irsâl ü îsâle bezl-i mâ-hasal-1 kudret eylemeniz fermânım olmağın hâsseten işbu emr-i celîlü'l- ‘ünvânım isdâr ve k1dvetü'l-emâsil ve'l-akrân sadr-1 a'zamım tatarlarından Mustafa ile irsâl olunmuşdur. İmdi vusûlünde ber minvâl-i muharrer Adana Beylerbeyisi sâbık mûmâ ileyh Yusuf Paşa maktûl-1 merkûmun emvâl ü eşyâ-yı nefise ve zehâ'ir ve hayvânât ve sâ'iresinden ve zevcesinin ${ }^{73}$ eşyâ ve halısından sırren ve 'alenen her ne ki ahz ü kabz eylemiş ise erbâb-1 vukûfdan bi’t-tefahhus zâhire ihrâcı ve zevce-i merkûmenin eşyâsını mukaddem sâdır olan emrim mûcebince kendisine teslîm ve mâ'adâsını bir helâli girüye kalmayarak ma'rifetiniz ve ma'rifet-i şer' ve mübâşirân-1 merkûmân ma'rifetleriyle ve cümle ittifâkıyla cânib-i mîrîçün istirdâd ve ahz ü kabz ve mahall-i me‘mene vaz' ve hıfz ve mukaddem fermânım olduğu vechile eşyâ-yı nefîseyi 'aynen ve eşyâ-yı sakîle ve hayvânât ve tuz ve koza ve hubûbât ve emlâkini değer bahâlariyla tâliblerine fürûht ve hâsıl olan esmânını zimmet-i mîriye ve duyûn-1 sâ'iresine mahsûben Der-'aliyyeme irsâl ü isâle bezl-i vus’ ü makderet eyleyesiz ve siz ki mübâşirân ve a'yân ve sâ'ir iş erlerisiz sizler dahi maktûl-1 merkûmun paşa-yı mûmâ ileyh tarafinda olan emvâl ü eşyâsının bir helâli girüye kalmayarak zâhire ihrâc birle istirdâdına bi'l-ittifâk sa'y ü gayret ve mûcib-i emr-i şerîfimle 'amel ü hareket eylemeniz bâbında fermân-1 'âlîşânım sâdır olmuşdur. Buyurdum ki: Hükm-i şerîfimle ( ) vardıkda bu bâbda vech-i meşrûh üzere şeref-yâfte-i sudûr olan işbu emr-i şerîf-i 'âlîşân-1 vâcibü'l-imtisâlimin mazmûn-1 münîfi üzere 'âmil olub hilâfından be-gâyet mübâ'adet eyleyesiz. Şöyle bilesiz 'alâmet-i şerîfe i'timâd kılasız. Tahrîren fî'l-yevmi'r-râbi' 'aşer min Ramazani'l-mübârek sene 'aşer ve mi'eteyn ve elf.

Bi-makāmı Kostantiniyyeti'l-mahrûse 
Sira No : 28

Belge No : Adana Ş. S. 57, img. 10, sayfa 13, belge 35

Tarih : : 19 N $1210 / 28$ Mart 1796

Konu : : Adana'dan beş yüz nefer süvari asker bedeli olarak 25.000 kuruştan 10.000 kuruşunun afv edildiğine ve geriye kalan 15.000'in yollanmasına dair ferman.

Tekeoğlu'nun fermân sûretidir. Sahh

İftihârü'l-emâcid ve'l-ekârim câmi 'u'l-mehâmîd ve'l-mekârîm el-muhtassu bi-mezîdi ‘inâyeti'l-meliki'd-dâ'im Dergâh-1 Mu'allâm kapucıbaşılarından Adana Mütesellimi Mîr Ahmed dâme mecdühu ve mefâhirü'l-kuzât ve'l-hükkâm me âdinü'l-fezâ'il ve'l-kelâm Tarsus sancağının hâvî olduğu kazâların kâdîları ve nâ'ibleri zîde fazluhum ve kıdvetü'l-emâcid ve'l-a'yân Tarsus voyvodası zîde mecdühu ve kıdvetü'l-emâsil ve'l-akrân rikâb-1 hümâyûnum kā'immakām çukadârlarından zikr-i âtî husûsa me'mûriyetiyle ol cânibde olan Mustafa zîde kadrühu tevkî'-i refî̀'-i hümâyûn vâsıl olıcak ma 'lûm ola ki:

Sen ki kapucubaş1-i mûmâ ileyhsin eyâlet-i mezbûrede Tekeli 'aşireti Tekeli Ali Bey ma'rifetiyle geçen sene ${ }^{74}$ tahrîr ve ordu-yı hümâyûnuma tesyîri tertîb olunan beş yüz nefer süvâri askerin irsâli bâbında fermân-1 'âlîşânım sâdır olmuş ise dahi ordu-yı hümâyûnum sevâhil-i Mısriyye'de olmak takrîbiyle neferât-1 merkûme irişemeyeceği zâhir ve techîz ve irsâlinde ahâli-i memleket masârıf-ı kesîreye dûçâr olacakları zâhir olmak mülâbesesiyle Anadolu cânibinden tertîb olunan mürettebât-1 seferiyyenin nakl ü îsâli 'asîr olanların bedelleri tanzîm ve tahsîli zımnında hâlen serdâr-1 ekremim tarafından Der-sa'âdetime vârid olan defterde zikr olunduğu üzere ol mikdâr askerin beher neferine ellişer guruşdan yirmi beş bin guruşun on bin guruşu afv ve bâkî kalan on beş bin guruşun tahsîli isti ‘câlini hâvî emr-i şerîfim 1sdâr ve tisyâr olunmuşdu. Tarsus kâdîsının vârid olan bir kıt'a i'lâmı mefhûmunda Tarsus sancağı dâhilinde olanlar bi'l-cümle eyyâm-1 şitâda Adana sancağında sâkin olmalarıyla bundan akdem sana hitâben ordu-yı hümâyûnumdan emr-i şerîfim vürûdunda mûmâ ileyh tarafından dahi mübâşir ta 'yîn ve mebâliğ-i mezbûre 'aşîret-i merkûmeden mutālebe olundukda kışlaklarına nüzûl itmedikce edâ idemeyeceklerini tahrîr ü inhâ eylemiş mukaddem sâdır olan evâmir-i şerîfim mûcebince neferât-1 merkûmenin gayr-1 ez afv ü tenzîl on beş bin guruşun bir an akdem tahsîl ve tesyîrine bezl ü say-1 makderet eyleyesin ve sen ki mübâşir-i merkûmsin meblağ-1 mezbûrun bu ana kadar tahsîl olunmaması mücerred senin tekâsül ü kusûrundan ve emr-i mübâşeretine 'adem-i takayyüdünden neş'et etmiş olduğu ma'lûm olunmuşdur. Bundan böyle dahi meblağ-1 mezbûrun tahsîlinde kusûr ü tekâsülün istimâ‘ olunmak lâzım gelür isebir dürlü cevâba kâdir olamayub te'dîb ü gûşmal kılınacağını bilüb ana göre 'amel ü hareket ve tahsîle sa'y ü gayret eyleyesin ve siz ki kuzât ve nüvvâb ve voyyvoda-1 mûmâ ileyhümâsız sizler dahi emr-i şerîfimle 'amel ü hareket eylemeniz bâbında fermân-1 'âlîşânım sâdır olmuşdur. Buyurdum ki: Hükm-i şerîfimle işbu emr-i 'âlîşân-1 vâcibü'l-ittibâ' ve lâzımü'l-imtisâlimin mazmûn-1 münîfi birle 'amel idesiz. Şöyle bilesiz 'alâmet-i şerîfe i'timâd kılasız. Tahrîren fi’l-yevmi’t-tâsî' aşer şehri Ramazan sene 'aşere ve mi' eteyn ve elf.

Bi-makāmı Kostantiniyyeti'l-mahrûse 
Sira no $\quad: 29$

Belge no :BOA, C. DH. 11/533

Tarih $\quad: 3$ L $1210 / 11$ Nisan 1796

Konu : Ahmed Bey’in Adana mütesellimi olarak tayin edilmesine dair

Kapu kethüdâsı olduğum hâlen İsmail muhâfizı mîr-mîrân-1 kirâmdan Mehmed Paşa kullarına bu def'a avâtıf-1 aliyye-i mülûkâne ve avârıf-1 behiyye-i hüsrevâne ibkāsı inâyet ve ihsân buyurulan Adana eyâletinde mütesellim olan müteveffâ Hasan Paşa hafîdi Ahmed Bey kulları vücûhuyla re‘âyâ-perver ve müstakîmü’l-etvâr olmağla mîr-i mûmâ ileyh kullarını kemâ-kân eyâlet-i mezkûra mütesellim nasb ü ta 'yîn ve iktizâ iden fermân-1 âlî 1sdârı bâbında emr ü fermân devletlü inâyetlü efendim sultânım hazretlerinindir.

Sahh. Mûcebince mütesellimlik emri virilmek buyuruldu. 3 L sene 210.

Tevcîhi Târîhi görüle. Sahh.

Adana eyâleti İsmail muhâfızı olub Rumeli Beylerbeyliği pâyesi olan Mehmed Paşa’ya tevcîh ba'dehu 3 L sene 210 târîhinde kemâ-kân ibkâ kılınmışdır. Fermân devletlü sultânım hazretlerinindir. 
Sira No : 30

Belge No : BOA, C. ML 462/18784-1

Tarih : : 15 L 1210 / 23 Nisan 1796

Konu : Beş seneden beri çekirge istilası ve diğer sebeplerden dolayı Adana nüfusunun on iki bin evden üç yüz eve düştüğüne ve bundan dolayı kendilerinden imdadiye alınmasının caiz olmamasına rağmen Adana'nın hac yolu üzerinde olmasından dolayı menzil nizamının devamı için beş bin guruş imdadiye tayin edildiğine dair.

Mîr-mîrân-1 kirâmdan Adana Beylerbeyisi Yusuf Paşa'ya ve Adana kâdîsına hüküm ki:

Adana kazâsı fi'l-asl on iki bin evden ibâret ve memerr-i hüccâc-1 Müslimîn iken beş seneden berü vukû' bulan ihtilâl ve cerrâr istilâsı ve ba'zı ilel ü esbâba mebnî ekseri diyâr-1 âhara müteferrik ve el-hâletü hâzihi üç yüz eve münhasır ve tarîk-i câdde olmak mülâbesesiyle menzillerinin idâresi küllî meblağa muhtâc olub ahâlîlerinin bir vechile liyâkatleri olmadığını beyân iderek menzil-i mezkûra imdâd olmak üzere Adana' da vâk1' penbe bid 'ati mâlından senevî on bin guruş ta 'yînine müsâ‘ade olunmak niyâzında olduklarını sen ki paşa-yı mûmâ ileyhsin sen kā’imende ve Adana kâdîsı i'lâm ve ahâlîsi mahzar ve Der-sa'âdetime gelen çend nefer ahâlî arzıhâllerinde tahrîr ve inhâ itmeleriyle kuyûda mürâca'at olundukda Adana menzilinin on bir re's bârgîri ve gayrı ez-ücret senevî yedi yüz doksan yedi buçuk guruş bârgîr bahâsı olub Adana kazâsının tertîb olunan hâne-i avârızları mukâbili Adana kazâsı ahâlîleri tarafından i'mâl ve idâresini hükkâm ve zâbitân-1 beldenin 'uhde-i ihtimâmlarına muhavvel olmağla bir sene zarfinda kazâlarına her kaç guruşa menzilci istîcâr ve kaç guruş imdâdiye ile mukâvele iderler ise mahallinde cümle ma'rifeti ve ma 'rifet-i şer'le ber-vech-i ta'dîl tevzî́ ve yerlü yerinden cem‘ ü tahsîl ve menzilcilerine edâ ve teslîm birle menzillerinin hüsn-i nizâm üzere i'mâl ve idâresine ihtimâm ü dikkat eylemeleri menâzilin şurût-1 kadîmesinden idüği mevkûfâtdan der-kenâr olunmağla bu sûretde penbe rüsûmu Îrâd-1 Cedîd Hazînesi vâridâtından olub inhâ olunduğu üzere rüsûm-1 mezkûreden imdâdiye ta'yîni câ'iz olmayub ancak fî̀ nefsi'l-emr Adana memerr-i hüccâc olub menzil-i mezkûrun hüsn-i nizâm üzere idâresi lâzimeden olmağla istediğin beş bin guruş imdâdiye ta 'yîn olunub meblağ-1 mezkûrun iki bin beş yüz guruşu Adana cizyesinin iki yüz on senesi mâlından ve iki bin beş yüz guruşu dahî eyâlet-i Adana mukāta'asının kezâlik iki yüz on senesi mâlından ta 'yîn ve tahsîs kılınmak fermânım olmağın bâ-telhîs fî 28 Z sene 1209 târîhinde mufassal emr-i şerîf verildiği mukayyeddir. Fermân devletlü sultânım hazretlerinindir. Fî $25 \mathrm{~L}$ sene 1210.

(Pençe)

Bu makûle cizyelerin maktû' 'an virildiği var mıdır Cizye Muhâsebesinden görüle.

Öteden berü çürük ve bî-hâsıl olduğuna binâ'en mukayyed olan altmış beş bin iki yüz doksan altı buçuk guruş mâlım an-hızâne ve mevâcib tezkirelerine havâle olunugelen Silistre cizyesi vukû' bulan sefer-i hümâyûn takrîbiyle der-'uhde olunan senelerin hâsılâtı otuz bin guruşa 
iblâğ1 mümkin olmamağla el-hâletü hâzihi hâsılâtına nazaran ve sâbıklarına kıyâsen doksan bir senesinden iki yüz altı senesine gelince yirmişer bin ve altı senesinden dokuz senesine gelince yirmi bir bin ve dokuz ve on senelerinde yirmi altışar bin guruşa maktû'an virildiği ve Erzurum cizyesi dahî mukaddemen Abdurrahman Paşa nizâmı üzere yüz kırk bin guruş mâl-1 maktû‘ ile Erzurum Gümrügü Malikâne mutasarrıflarına merbût olduğu mukayyeddir. Fermân devletlü inâyetlü sultânım hazretlerinindir. Fî 19 L sene 1210.

(Pençe)

Der-kenâr olunan menzil ocakliğı takrîri tesvîd oluna.

Mevkûfâtdan görüle. 
Sira No : 31

Belge No : BOA, C. ML 462/18784-2

Tarih : : 16 L 1210 / 24 Nisan 1796

Konu : Adana cizye cibayeti emaneten kendisine ihale edilmiş olan maktul Karcı Mehmed A ğa'nın vefatı üzerine cizye cibayetinin Adana Mütesellimi Ahmed Bey’e 12.500 kuruşa ihale edildiğine dair.

Takrîr-i kullarıdır ki:

Adana cizye cibâyeti mukaddemen maktûl Karcı Mehmed Ağa’ya emâneten ihâle ve tefvîz buyurulmuş olduğu misüllü işbu bin iki yüz on bir senesine mahsûben sâlifü'z-zikr cizye cibâyeti maktû'an on iki bin beş yüz guruşa hâlen Adana Mütesellimi El-hâcc Abdullahpaşazâde Ahmed Bey kullarının 'uhde-i âcizânesine ihâle ve tefvîz buyurulmasını bu def'a mîr-i mûmâ ileyh kulları tahrîren niyâz ve iltimâs etmiş idüği ma'lûm-1 âlîleri buyuruldukda ber-minvâl-i muharrer cizye cibâyetinin sene-i merkûma mahsûben ol-mikdâr mebâliğ-i maktû‘ ile mîr-i mûmâ ileyh kullarına ihâle ve tefvîzi muvâfık-1 re'y-i âlîleri ise ol bâbda emr ü fermân devletlü inâyetlü efendim sultânım hazretlerinindir.

Teslîmâtları sergiden derkenâr oluna.

Teslîmâtları sürhle ve cânibde işâret olunduğu üzere olub mâ'adâ teslîmâtı kaydı bulunmamışdır. Fermân devletlü inâyetlü sultânım hazretlerinindir. Fî 16 L sene 1210.

(pençe)

Cizye kaleminden keyfiyeti serî‘an derkenâr oluna.

Dokuz ve on seneleri dahî buna.

(Siyakatla yazılan derkenar kayıtları alınmamışdır Y.K.)

Maktûl-i merkûmun iki yüz sekiz senesi 'uhdesine ihâle buyurulan cizye-i merkûme içün vürûd iden mümzâ defter mûcebince tevzî‘ât ve hâsılâtından bâ-fermân mahsûb olunan mesârifâtı ve teslîmât ve el-yevm bâkîsi keyfiyeti minvâl ve meşrûh üzere olduğu mukayyeddir. Fermân devletlü inâyetlü sultânım hazretlerinindir. Fî 14 L sene 1210.

(pençe)

İki yüz dokuz senesi cizye-i mezbûrun fi'l-asl mâl ve teslîm ve bâkîsi ve on senesi hâsılât ve teslîmâtı minvâl ve meşrûh üzere olduğu mukayyed olub dokuz senesinden peşinden mâ‘adâ teslîmi var ise sergiden görülmeğe muhtâcdır. Fermân devletlü inâyetlü sultânım hazretlerinindir. Fî 14 L sene 1210.

(Pençe) 
Sira No : 32

Belge No : Adana Ş.S. 56, img. 28, sayfa 67, belge 14

Tarih : 27 L 1210 / 5 Mayıs 1796

Konu : : 1211 senesi Adana cizyesinin Ahmed Bey’e 13.000 guruşa ihale edildiğine dair

Kıdvetü'l-kuzât ve'l hükkâm ma'denü'l-fazlı ve'l-kelâm Mevlânâ Adana kâdîsı zîde fazluhu ve kıdvetü'l-emâcid ve'l-a‘yân Adana Mütesellimi Abdullahpaşazâde Ahmed Bey zîde mecdühu ve k1dvetü'l-emâsil ve'l-akrân bu husûsa mübâşir ta'yîn olunan defterdâr-1 ş1kk-1 evvelim etbâ'1ndan Halil zîde kadruhu tevkî‘' refî‘-i hümâyûn vâsıl olıcak ma 'lûm ola ki:

Bundan akdem iki yüz sekiz senesinde Adana kalemi cizyesinin emr-i cibâyeti maktûl Karc1zâde Mehmed'e ihâle ve tefvîz olunduğu misüllü iki yüz on bir senesine mahsûben dahi kalem-i mezbûrun on iki bin beş yüz guruşa ber vech-i maktû' sen ki mütesellim-i mûmâ ileyhsin 'uhdene ihâle ve tefvîz olunması husûsunu inhâ ve iltimâs eylediğini beyân birle ber minvâl-i muharrer sene-i mezbûreye mahsûben kalem-i mezbûr cizyesinin 'uhdene ihâle olunmasını hâcegân-1 divân-1 hümâyûnumdan Mühimmât-1 cebehâne nâzırı k1dvetü’l-emâcid ve'l-a‘yân Hasan zîde mecdühu istid 'â etmekle Adana cizyesinin gayr-1 ez ma âş fi'l-asl yirmi beş bin üç yüz yetmiş sekiz buçuk guruş mâlı olduğu cizye muhâsebesinde mukayyed olub ancak el-hâletü hâzihi cizye-i mezkûrenin hâsılâtı mâl-1 mukayyedi mikdârına bâliğ olmayacağı tashîh olunmağla bi-mennihi ta'âla bundan böyle tanzîmine dikkat ile mâl-1 asliyyesine iblağa ikdâm olunmak şartıyla mârrü'z-zikr on iki bin beş yüz guruşa beş yüz guruş dahi zamm ile gayr-i ez ocaklık menzil işbu iki yüz on bir senesine mahsûben on üç bin guruş maktû'an 'uhdene ihâle ve tefvîz olunması husûsuna irâde-i 'aliyyem ta'alluk idüb ber vech-i muharrer cibâyet ve tahsîli hazine-i 'âmirem defter-i vâridâtda 'uhdene kayd ü berât ve evrâk boğçası mübâşir-i merkûm ma'rifetiyle tarafına irsâl olunmağla vusûlünde boğçayı ahz ve gurre-i Muharremü'l-haramda ma 'rifet-i şer' ile mühürlerin fekk ve küşâd ve kalem-i mezbûr ve tevâbi'inde sâkin ve mevcûd yerlü ve yabancı ve mürûr (ü) 'ubûr eden ehl-i zimmetin esnâf-1 selâse üzere hâl ve istihkāklarına göre 'ale'r-ru'us evrâkları tevzî' ve iktizâ eden mâl-1 cizyelerinin cibâyet ve tahsîline şürû' ü mübâşeret birle evvel-be-evvel tahsîl ve makbûzun olan mâl-1 cizyeden divân-1 müşeyyedü'l-erkân-1 mülûkânemde ihrâcı musammem olan kapum kulları mevâciblerine müretteb bin beş yüz guruş peşîn akçasıyla kaleminden muhrec mümzâ sûret-i defterde terkîm üç yüz seksen yedi guruş harc-1 aklâm ve 'avâ'idât-1 sâ'ireyi mübâşir-i merkûma teslîmen Der-'aliyyeme irsâl ve tesyîr eylemen fermânım olmağın işbu emr-i celîlü'l-kadrım ısdâr ve mübâşir-i merkûm ile irsâl olunmuşdur. İmdi vüsûlunde bâlâda zikr olunduğu üzere cizye-i mezbûr işbu bin iki yüz on bir senesine mahsûben gayr-i ez ocaklık menzil on üç bin guruşa maktû'an 'uhdene kayd ve berât ve evrâk boğçası tarafına irsâl olunmuş olduğu ma'lûmun oldukda sene-i mezbûreye mahsûben kalem-i mezbûr ve tevâbi 'inde sâkin ve mevcûd yerlü ve yabanc1 ve mürûr (ü) 'ubûr eden ehl-1 zimmetin esnâf-1 selâse üzere hâl ve istihkāklarına göre 'ale'r-rû'us evrâklarını tevzî‘ ve iktizâ eden mâl-1 cizyelerinin cibâyet ve tahsîline şürû' 
ve mübâşeret birle evvel-be evvel tahsîl ve makbûzun olan mâl-1 cizyeden mevâcibe müretteb bin beş yüz guruş peşîn akçasıyla üç yüz seksen yedi guruş harc-1 aklâm ve 'avâ'idât-1 sâ'ireyi mübâşir-i merkûma teslîmen Der-'aliyyeme irsâl ve tesyîre ziyâde ihtimâm ü dikkat eyleyesin. Şöyle ki mevâcib-i mezbûrun be-her hâl ihrâcı bu makûle mürettebâtın vaktiyle gelüb teslîm-i hazîne-i 'âmirem olunmasına mütevakkıf ve menût olmağla hemân meblağ-1 mezbûru tedârük ve hazîne-i 'amireme ve mahallerine edâ ve teslîme sa'y ü ikdâm eyleyesin ve sen ki mübâşir-i merkûmsun me'mûrü'l-mebânî olduğun berât ve evrâk boğçasını mahsûben bi's-selâme mahalline îsâl ve mütesellim-i mûmâ ileyhe teslîm ve mevâcibe müretteb sâlifü’z-zikr bin beş yüz guruş peşîn akçasıyla sûret-i defterde terkîm olunan harc-1 aklâmı mütesellim-i mûmâ ileyhden ahz ve seyr-i serî‘ ile ihrâc-1 mevâcibden mukaddem getürüb hazîne-i 'âmireme ve mahallerine edâ ve teslîme sür'at ve esnâ-yı râhda ve mahallinde bilâ mûcib meks ü ikāmetden mücânebet eyleyesin ve sen ki kâdî-i mûmâ ileyhsin sen dahi mûcîb-i emr-i şerîfimle 'amel ü hareket eylemen bâbında fermân-1 'âlîşânım sâdır olmuşdur. Buyurdum ki hükm-i şerîfimle ( ) vard1kda bu bâbda vech-i meşrûh üzere şeref-yâfte-i südûr olan işbu emr-i şerîf-i celîlü’ş-şân-1 vâcibü'l-ittibâ' ve lâzımü'l-imtisâlimin mazmûn-1 münîfi üzere 'âmil olasız hilâfından ihtirâz eyleyesiz şöyle bilesiz 'alâmet-i şerîfe i'timâd kılasız. Tahrîren fî̀'l-yevmi’s-sâbi' '1şrîni Şevvâl sene 'aşer ve mi'eteyn ve elf.

Bi-makāmı Kostantiniyyeti'l-mahrûse. 
Sira No : 33

Belge No : Adana Ş.S. 56, img. 29, sayfa 69, belge 13

Tarih : : 28 L 1210 / 06 Mayis 1796

Konu : : Adana Mütesellimi Hasanpaşazâde Ahmed Bey’e verilen cizye berâtıdır.

Adana Mütesellimi Hasanpaşazâde Ahmed Bey’in cizye berât-1 şerîf-i 'alîşânıdır.

NIŞÂN

Memâlik-i mahrûsemde vâk1' ehl-i zimmetden Yehud ve Nasarâ'nın şer'an ru'uslarına madrûbe olan cizyeleri beytü'l-mâl-1 müslimînin emvâl-i meşrû'asından olmağla mezheb-i Hanefiyye üzere a'lâ ve evsat ve ednâ i'tibârıyla evrâk-1 cizye sene-i sâbıkı üzere küşâd ve bin iki yüz on bir senesi Muharremü'l-harâm gurresinden tevzi'ine mübâderet olunmak bâbında hatt-1 hümâyun-1 şevket-makrûnum sâdır olmağın bin iki yüz on bir senesine mahsûben olmak üzere Adana ve Sis ve Tarsus ve İçil sancaklarında ve tevâbi 'inde sâkin ve mevcûd yerlü ve yabancı ve mürûr-1 'ubûr iden ehl-i zimmet kefere ve Yehud ve Erâmine-i 'Acem tâ'ifelerinin şer'an üzerlerine edâsı lâzım gelen bin iki yüz on bir senesi cizyeleri cibâyetine sene-i mezbûre Muharremi gurresinden mübâderet eylemek dört yüz kırk üç a'lâ ve üç bin beş yüz seksen sekiz evsat ve yedi yüz dört ednâ evrâkına esnâf-1 selâse i'tibârıyla cem'an dört bin yedi yüz otuz beş evrâk ile cibâyeti Adana mütesellimi işbu râfî-i tevkî‘'i refî‘ü’ş-şân-1 hakanî kıdvetü’l-emâcid ve'l-a'yân Hasanpaşazâde Ahmed zîde mecdühuya derûhde ve tefvîz olunub bu berât-1 'âlîşânı virdim ve buyurdum ki: Cizyedâr-1 mûmâ ileyh varub gurre-i Muharremü'l-harâm’da hâkimü'l-vakt muvâcehesinde mîrî mührüyle memhûr cizye boğçasının mühürlerin fekk ve evrâkda olan mühürler ile tatbîk olundukdan sonra bir kiseye vaz' ve vilâyet kâdîsı mühürleyüb Der-sa'âdetime irsâl ve kalem-i mezbûra tâbi' her belde ve karyede sâkin ve mevcûd yerlü ve yabancı ve mürûr u 'ubûr iden ehl-i zimmet kefere ve Yehud ve Erâmine-i Acem tâ'ifelerinin emred-i mürâhik hükmüne dâhil olub şer'an cizyeye müstehak olan gulâmları gereği gibi takayyüd ve ihtimâm ile tefahhus olunub bir ferdî hâric ve kâğıdsız kalmamak şartıyla vech-i şer'i üzere ahâlisi beyninde mülk ve emlâkine nazar olunub esnâf-1 selâsenin kang1 sınıfından add ve i'tibâr olunur ise hatt-1 hümâyûn-1 şevket-makrûnumla virilen nizam-1 cedîd mûcebince zâhirü'l-gınâ mükesser olanlarından a'lâ i'tibâr on bir esedî guruş ve vasatü'l-hâl olanlarından evsat i'tibârıyla beş buçuk guruş ve fakîr-i mu'temilinden ednâ i'tibarıyla iki buçuk guruş ile bir rub' alınub 'aynî esedî guruş tedârükünde acz ve 'usreti olanlarından 'aynî guruş taleb olunmayub ecnâs-1 nükûddan ne gûne getürürler ise hâlisü'l-'ayâr ve tammü'l-vezn olanları râyic oldukları üzere İstanbul findık altınu yedi guruşa ve İstanbul zer-i mahbûbu beş guruşa Misır zer-i mahbûbu dört guruşa ve Misır findık altunu altı guruşa ve tuğralı sağ paranın her kırk 'adedi bir guruşa ve seksen 'adedi iki bin ve yüz 'adedi yüzlük hesâbıyla alınub mâl-1 cizyeleri bu vechile cibâyet ve tahsîl ve şürût-1 mukarrere-i mezkûreye kemâl ihtimâm ü i'tidâl üzere mürâ'at olunub haddi tecâvüz ve ta'addi ile sebîl-i sadakat ve tarîk-i istikāmetden 'udûl edenleri şer'an müstehak olan cezâları tertîb oluna ve ehl-i zimmet 
keferenin her birine mîrî mührüyle memhûr eşkâli ile birer kağıd virilüb 'ummâl-1 cizyenin tevzî' eylediği evrâkın a'lâsından on iki ve evsatından dokuz ve ednâsından altı para ma'îşet ve bundan mâ'adâ her bir varakdan birer para cizye muhâsebecisi ve kâtiblerine ücret-i kitâbet ta'yîn olunmağla müctemi' olan mâl-1 cizyeden hîn-i muhâsebede deynlerine mahsûb olunmak ve memâlik-i mahrûsemde vâki' evkâf karyelerinde sâkin ehl-i zimmetden selâtîn-i 'izâm ve vüzerâ-yı kirâm ve mîr-mîrân ve sâ'irlerinin havâs ve ocaklıklarına dâhil ve ba'zı esbâba binâ'en defterden ve maktû' olan rahib ve batrik ve kasîs ${ }^{75}$ ve batrik ile ellerine berât alub tercümânlık ve müsellemlik ve mu'âfiyet iddi'âsında olanlar bi'l-cümle ref' ve mâdâmki iktisâb-1 'amale kâdir olub iktisâbdan mâni' olur zamânda ve zarâret ve kalem ve yâhûd ekser 'âmminde marîz olmak gibi a'zâr-1 sâhîhası olmayan sâ'ir ehl-i zimmetden istisnâ olunmayub cümlesinden vech-i şer'i üzere tahammül ve istihkāklarına göre bir vahidden esnâf-1 selâse i‘tibârıyla cizyeleri cibâyet olunmak ve cizyeye müstehak olmayan sabî ve zâhirü’l-gınâ olmayub pîr ü fânî ve 'amel-mânde olub bir vechile kâr ü kisbe iktidârı olmayanlarından hilâf-1 şer'-i şerîf cizye taleb olunmamak ve 'ehl-i zimmetden âyende ve revende ve def'aten edâya kudreti olanlarından mâ'ada ancak fakîr mu'temilinden dört taksît ile cem‘ ü tahsîl idüb lâkin cizyedârlar mâl-i cizyeyi vakt ü zamânıyla hazîne-i 'amireme teslîm eyleyeler ve mâl-1 cizye nassen ve ictihâden îcâb eden vâridât-1 şer'iyyeden ve beytü'l-mâl-1 müslimîn olmakla ehl-i zimmet sükût-1 cizyeyi müstelzim olur 'özürden sâlim iken dil ve safâ ile müstehak olan cizyelerin virmemek ${ }^{76}$ içün bî-vech 'özür îrâdına ictirâ' ve yâhûd bir tarîk ile ibâ ve bir yerde ihfâ ve yâhûd a'lâya müstehak iken evsat ve evsata müstehak iken ednâ cizyesin virmeğe tasaddî ederi olur ise cizye-i şer'iyyelerinden imtinâ eyledikleriçün ancak o makûlenin rakabesi üzerine madrûbe olan cizyeleri alındıkdan sonra eşedd-i 'ikâb ile îcâb eden cezâları tertîb oluna ve ehl-i vilâyetden ba'z1 zî-kudret kimesnelerin bâğ ve bâğçe ve çiftlik ve değirmen ve mandıralarında çoban ve değirmenci ve ner oğlanı nâmıyla ve sâ'ir bahâne ile ehl-i zimmeti istishâb ve cizyelerin virdürmeyüb bu gûne harekete cesâret edenler bâ'isü'l-hazelân-1 ebed olur 'ukûbât-1 şedîde ile mu'âteb olacakların mukarrer ve muhakkak bilüb selâmet-i halleri içün kemâl-1 intibâh üzere hareket eyleyeler ve cizyedârlar ve cizyedârlarının mukâyeselerine dâhil olmayan re'âyâya hîle ile hufyeten evrâk gönderüb tevzî' olunduğu şer'an sâbit olundukda virdiği evrâk girü kendüye redd ve akçası bi’t-tamâm tahsîl ve asıl cizyedârlarına teslîm ve tahammül ve istihkāklarına göre evrâkları mukâyesesine dâhil oldukları cizyedâr tarafindan virilüb bir vechile ta'allül ve muhâlefet ittirilmemek ve ba'zı re'âyâ sâkin olduğu kasaba ve kurâda mün'im ve mütemevvil a'lâ ve yâhûd evsata mütehammil iken a'lâ ve evsat cizyesi virmemek içün civârlarında vâkı' âher kazâ cizyedârlarından hîle ile evsat ve ednâ kâğıdı alub mîriye gadr eylemek ihtimâli olur ise ol asılların ahâlisi beyninde mülk ve emlâkine nazar olunub esnâf-1 selâsenin kangı sınıfından 'add ve i'tibâr olunur ise vech-i şer'i üzere tahammül ve istihkāklarına göre evrâkları virilüb lâkin bu bahâne ile re‘âyâ fukarâsına gadr-i tecâvüz eylemeyeler ve her bir ehl-i zimmetin tahammül ve istihkāklarına göre cizyeleri cibâyet olunmak muktezî iken ba'zı mahallât ve kurânın kocabaşıları kendü cizyelerin tahfîf içün topdan

75 Kasîs kelimesi keşiş ve piskopos anlamındadır.

76 Metinde "evirmemek” içün şeklinde yazılmıştır.

Belgeler, Cilt: 37/Say1: 41; 39-210 
evrâk alub re‘âyâya istihkāklarına göre virmeyüb mâlı her ne ise beynlerinde hesâb ve hilâf-1 şer'-i şerîf 'ale's-seviyye tevzî' olunduğu sem'-i hümâyûnuma ilkâ olunmağla bu bid'at-1 kerîhe dahi men' olunub her bir ehl-i zimmetin tahammüllerine göre cizyedâr yediyle evrâkları virilüb cizyeleri cibâyet olunmak hâsıl-1 kelâm hilâf-1 şürût-1 berât bir ferdi hâric ve kağıdsız kalmamak şartıyla vech-i şer'i üzere her birinin tahammül ve istihkāklarına göre evrâkları virilüb cizye-i şer' iyyeleri cibâyet olundukdan sonra kasaba ve kurâ üzerlerine topdan evrâk tarh ve tahmîl olunduğu haberi olur ise bilâ imhâl bu gûne harekete cesâret edenlerin cezâları tertîb olunacağını mukarrer ve muhakkak bilüb cibâyetine me'mûr 'âmiller dahi câdde-i hakdan7 'udûl eylemeyüb kemâl-i istikāmet üzere hareket ve hilâf-1 şürût-1 berât-1 'âlîşân re'âya fukarâsından başka ma'îşet ve zahîre ve kâtibiyye ve kolcu akçası nâmıyla bir habbe taleb etmeyeler ve gerek kuzât ve nüvvâb harc-1 mahkeme nâmıyla re'âyâ fukarâsından ve 'ummâl-1 cizyeden kalîl ve kesîr min ba'd nesne mutālebe eylemeyeler şöyle ki: Kâdîlar cizyedârlar celb-i mâl sevdâsıyla re'âyâ fukarâsına zulm ü ta'addî ederler ise sırran ve 'alenen tefahhus ve tecessüs olunub izdiyâd aldıkları zâhir olur ise kayd u bend ile âsıtâne-i sa'âdetime irsâl ve şer'an muhkem haklarından gelünüb ana göre bu berât-1 'âlîşânımın şürûtuna mürâ'ât olunub kâdîlar ve voyvodalar ve kurâ zâbitları ve sâ'ir sükkân-1 vilâyet bi'l-ittifâk cizye cibâyeti husûsunda cizyedâra emânet ve müzâheret ve muhâlefet ederi olur ise haklarından gelinmek üzere isim ve resimleriyle Der-sa'âdetime 'arz ü i'lâm eyleyeler ve her bir neferin cizye mâlını edâ eylediği ma'lûm olmak içün cizyedârlar başka defter tutub kasabada olanların mahallesiyle ve kurâda olanların karyesiyle ve mürûr (ü) 'ubûr edenleri isim ve resimleriyle 'ale'l-esâmî defter ve cizye muhâsebesine teslîm eylemek üzere der-i devlet-medârıma getüreler ve cizyedârlar kazâ ve kurâya tevzî‘ eylediği evrâkı min ba'd kolcular mühürlemeyüb ve eşkâlsiz kağıd virmeyüb hîn-i iktizâda def'-i iştibâh içün tatbîk olundukda mutâbık olmak içün kaleminde hıfz olunan mühürler ile mühürleyeler ve işbu berât-1 'âlîşânımda ta'yîn ve tasrîh olunan şürût ve kuyûdun tenfîz ve icrâsına her birleri gereği gibi ihtimâm eyleyüb hilâf vaz' ü hareketden ihtirâz ve ictinâb eyleyesiz. Şöyle bilesiz 'alâmet-i şerîfe i'timâd kılasız. Tahrîren fî'l-yevmi’s-sâmini '1şrîn şehri Şevvâl sene 'aşere ve mi'eteyn.

Bi-makāmı Kostantiniyyeti'l-mahrûse 
Sira No : 34

Belge No : Adana Ş.S. 56, img. 16, sayfa 31, belge 43

Tarih : : 28 L 1210 / 06 Mayis 1796

Konu : Hasanpaşazâde Ahmed Bey ve Mehmed Bey ve Mustafa Bey'in uhdelerinde olan Yörügân-1 Adana ve Tarsus ve tevâbi 'i mukāta'asından 1201-1202 yılları için toplanan paradan 44.361 kuruşun İstanbul'a gönderilip hazineye teslim edilmesi için.

Kıdvetü'l-kuzât ve'l hükkâm ma'denü'l-fazlı ve'l-kelâm Mevlânâ Adana kâdîsı zîde fazluhu ve iftihârü'l-emâcidi ve'l-ekârim câmi 'u'l-mehâmid ve'l-mekârim el-muhtassu bi-mezîdi 'inâyeti'l-Meliki'd-dâ‘im Dergâh-1 mu'allâm kapucubaşılarından mîrâhur-1 evvelim payesiyle hâlen Bozok Sancağı mutasarrıfı Mîr Süleyman dâme mecdühu tevki'-i refi'-i hümâyûn vâsıl olıcak ma'lûm ola ki:

Adana sâkinlerinden Hasanpaşazâde Ahmed Bey ve Mehmed Bey ve Mustafa Bey zîde mecdühumun ber vech-i mâlikâne 'uhdelerinde olan Yörügân-1 Adana ve Tarsus ve Tevâbi' i Mukāta'atı senevî dokuz bin sekiz yüz kırk dört buçuk guruş mâl ile mukayyed olmakdan nâşî mukāta'a-i mezbûrun iki yüz bir senesinden iki yüz on bir senesine gelince müctemi‘ olan doksan dokuz bin üç yüz on bir guruşu emvâl-i mîrîyesinden gayr-1 ez havâlât ü teslimât mukāta'a-i mezbûre mutasarrıfları mîr-i mûmâ ileyhimin kusûr kırk dört bin üç yüz altmış bir guruş zımmet-i sahîheleri olduğu kuyûddan müstebân olmağla bu makûle mukāta'at-1 mîriye emvâlinin bî-hûde 'ukde-i te'hîre dû-çâr olması kavâ'id-i mîriye-i müreccebeye mugâyir ve beher hâl tahsîline (dikkat) olunmak vâcibât-1 umûrdan idüğü zâhir olmakdan nâşî mûmâ ileyhimin zimmet-i mîriyeleri sen ki mîr-i mûmâ ileyhsin ma'rifetinle tahsîl olunmak bâbında bundan mukaddem emr-i şerîfim 1sdâr olunmuş olduğuna binâ'en gayr-1 ez havâlât ü teslîmât kusûr-1 zimmet-i sahîhaları olan meblağ-1 mezbûrun tahsîli be-her hâl senden matlûb-1 hümâyûnum olmağla mukaddem ve bu def'a sâdır olan evâmir-i 'aliyyem mûciblerince ${ }^{78}$ işbu emr-i 'âlîşânım 1sdâr ve bundan akdem bu husûsa me'mûren ol cânibde olan sadr-1 a'zam mektûbcusu hulefâsından Mehmed Emin mübâşereti ile irsâl olunmuşdur. İmdi ${ }^{79}$ kusûr ${ }^{80}-1$ mezkûr kırk dört bin üç yüz altmış bir guruşun bir akçası girüye kalmamak şartıyla bi-eyyi vechin kâne tamâmen ve kâmilen mîr-i mûmâ ileyhimden tahsîl ve eğer edâda ta 'allül ve muhâlefet ederler ise keyfiyetini serî‘an Der-sa'âdetim'e tahrîr ve inhâ eylemen fermânım olmağın te 'kîden ve isti'calen ${ }^{81}$ vusûlünde ${ }^{82}$ zikr olunan senelere mahsûben mukāta'a-i mezkûrun müctemi' olan ol mikdâr emvâl-i mîriyesinden gayr-1 ez havâlât ü teslîmât kusûr zimmetleri olan kırk dört bin üç yüz altmış bir guruşun tahsîli 'uhde-i liyâkatına ihâle olunmuş olmakdan nâşî beher hâl tahsîli senden matlûb-1 kat'i-i şâhânem idügü ma'lûmun oldukda zâtında merkûz olan gayret ve

78 Kelimenin üzerine rakamla 57 yazılmıştır.

79 Kelimenin üzerine rakamla 6 yazılmıştır

80 Kelimenin üzerine rakamla 7 yazılmıştır.

81 Kelimenin üzerine rakamla 5 yazılmıştır.

82 Kelimenin üzerine rakamla 6 yazılmıştır

Belgeler, Cilt: 37/Say1: 41; 39-210 
sadâkat muktezâsınca meblağ-1 mezkûrun bir akçası girüye kalmamak şartıyla her ne vechile ve ne tarîkle olur ise olsun 'alâ eyyi hâlin bi't-tamâm tahsîl ve seri'an ve 'âcilen Der-sa'âdetim'e irsâl ve hazîne-i ‘âmireme teslîmine sa‘y ü ikdâm eyleyesin şöyle ki meblağ-1 mezbûr vâridât-1 mukarrere-i mîriyemden olmakdan nâşî eğer bundan sonra dahi mîr-i mûmâ ileyhim edâda ta 'allül ve muhâlefet ile imrâr-1 vakt eder ise hemân keyfiyetini Der-sa'âdetim'e tahrîr ve inhâya müsâra'at ve hilâfına rızâ ihmâl ve müsâmahadan tevakkî ve mübâ'adet eyleyesin ve sen ki kâdî-i mûmâ ileyhsin sen dahî mûcib-i emr-i şerîfimle 'amel ü hareket eylemen bâbında fermân-1 'âlîşânım sâdır olmuşdur. Buyurdum ki hükm-i şerîfimle ( ) vardıkda bu bâbda vech-i meşrûh üzere şeref-yâfte-i sudûr olan işbu emr-i şerîf-i celîlü'ş-şânımın mazmûnıyla ‘âmil olasız şöyle bilesiz 'alâmet-i şerîfe i'timâd kılasız. Tahrîren el-yevmü's-sâmini '1şrîn Şevvâl sene 'aşer ve mi'eteyn ve elf. (28 Şevval 1210-06.05.1796)

Bi-makāmı Kostantiniyeti'l-mahrûse

Mûcebince Cabbarzâde'den buyuruldu dahi 1sdâr olmuşdur. 
Sira No : 35

Belge No : BOA, C. ML 462/18784-3

Tarih : : 29 L 1210 / 07 Mayıs 1796

Konu : Adana kalemi cizyesinin cibâyeti 1211 senesine mahsûben 12.500 guruşa Ahmet Bey'e tefvîz buyurulması hakkında

Hâcegân-1 Dîvân-1 Hümâyûndan Hasan Efendi kullarının takdîm eylediği bir kıt'a takrîri mefhûmunda bundan akdem iki yüz sekiz senesinde Adana kalemi cizyesinin emr-i cibâyeti maktûl Karcizâde Mehmed Ağa'ya ihâle ve tefvîz olunduğu misüllü iki yüz on bir senesine mahsûben kalem-i mezbûrun cibâyeti on iki bin beş yüz guruşa ber-vech-i maktû‘ ihâle olunmasını hâlen Adana Mütesellimi Abdullahpaşazâde Ahmed Bey kulları bir kıt'a mektûbuyla inhâ ve iltimâs eylediğini beyân birle ber-minvâl-i muharrer sene-i mezbûreye mahsûben kalem-i mezbûr cizyesinin mîr-i mûmâ ileyhe ihâle ve tefvîz buyurulması husûsunu tahrîr ve istid'a ider. Derkenâra havâle olundukda maktûl-i merkûmun sekiz senesine mahsûben ber-vech-i emânet 'uhdesine ihâle olunan kalem-i mezbûr cizyesinin gayr-1 ez-masârıf hâsılâtı olan on dört bin üç yüz altmış yedi guruşdan gayr-1 ez teslîmât sene-i mezbûreden zimmetinde iki bin sekiz yüz altmış yedi guruş ve dokuz senesine mahsûben kezâlik maktûl-i merkûmun 'uhdesine muhavvel olmakla gayr-i ez ma'âş fi'l-asl mâlı olan yirmi beş bin üç yüz yetmiş sekiz buçuk guruşun bin beş yüz guruşu ber vech-i peşîn teslîm olunub mâ‘adâ yirmi üç bin sekiz yüz yetmiş sekiz buçuk guruş bâkî kaldığı ve on senesine mahsûben hâsılâtı olan on bin beş yüz altmış beş buçuk guruşdan gayr-i ez-ocaklık mütenezzil ${ }^{83}$ yalnız sekiz bin altmış beş buçuk guruş teslîm-i Hazîne-i Âmire olunmuş olduğu ve bu makûle cizyelerin maktû' an verildiği mesbûk idüği cizye muhâsebesinden derkenâr olunmuşdur. Manzûr ve ma'lûm-1 devletleri buyuruldukda Adana eyâletinin perîşânlığı hasebiyle cizyesi dahî çürük ve bî-hâsıl olduğundan el-yevm buyuruldusu der-dest olub kimesne tâlib olmadığından ber vech-i muharrer maktû'an mütesellim-i mûmâ ileyhe ihâlesi muvâfik-1 re’y-i âlîleri ise istid‘â eylediği mikdâra beş yüz guruş dahî zammiyla on üç bin guruşa maktû'an der'uhdesi husûsunda ne vechile emr ü irâde-i seniyyeleri buyurulur ise emr ü fermân devletlü sa'âdetlü sultânım hazretlerinindir.

Sahh.

İzzetlü Defterdâr Efendi

Takrîriniz mûcebince tanzîm eyleyesiz deyu buyuruldu. 22 L sene 210.

Mûcebince cizye kalemine kayd olunub iktizâsına göre emri ru'ûs defterlerine ilmuhaberi verile. Ilmuhaber dâde.

29 L sene 1210. Kayd şod.

83 Metinde "Menzil”" şeklinde yazılmıştır.

Belgeler, Cilt: 37/Sayı: 41; 39-210 
Sira No : 36

Belge No : Adana Ş.S. 56, img. 16, sayfa 30, belge 44

Tarih : : 17 L 1210 / 25 May1s 1796

Konu : Yörügân-1 Adana ve Tarsus ve Sis Mukāta'asının 1210 malından Istabl-1 amire masrafi için 4470 guruşun toplanıp Der-sa âdete gönderilmesine dair fermân

Kıdvetü'l- emâcid ve'l-ekârim el-muhtassu bi-mezîdi ‘inâyeti'l-meliki'd-dâ'im dergâh-1 mu'allâm kapucubaşılarından mîrahûr-1 evvelim pâyesiyle Bozok sancağı mutasarrıfı Cabbarzâde Süleyman dâme mecdühu ve mefâhirü'l-kuzât ve'l-hükkâm me‘âdinü'l-fezâ‘il ve'l-kelâm ( ) ve ( ) ve ( ) kâdîları zîde fazluhum tevkî'-i refî‘i hümâyûn vâsıl olıcak ma'lûm ola ki:

İftihârü'l-emâcid ve'l-ekârim Dergâh-1 mu'allâm kapucubaş1larından hâlen Divân-1 Hümâyûnumda Çavuşbaşı olan Mehmed Said Bey dâme mecdühunun takdîm eylediği takrîri mefhûmunda bundan akdem iki yüz sekiz senesine mahsûben ma'rifetiyle idâre olunan Istabl-1 'âmirem masârıfiçün Yörügân-1 Adana ve Tarsus ve Sis Mukāta'asının iki yüz on senesi mâlından iki kıt'a rûznâmçe-i hümâyûnum temessükü mûcebince havâle olunan dört bin dört yüz yetmiş guruş mukāta'a-i mezbûre mutasarrıfları Ahmed ve Mustafa ve Mehmed nâm kimesnelerden Âsitâne-i sa'âdetimde matlûb olundukda meblağ-1 mezbûr bu tarafda edâ olunmayub öteden berü mahallinde edâ oluna geldiğini inhâ itmeleriyle zikr olunan dört bin dört yüz yetmiş guruş mahallinde îcâb ü iktizâ idenlerden bi eyyi hâlin tahsîl ve tarafına irsâl ü tesyîr olunmak üzere emr-i şerîfim sudûrunu istid'â itmekle mûcebince 'amel ü hareket olunmak fermânım olmağın işbu emr-i 'âlîşânım sâdır ve ( ～） ile irsâl olunmuşdur. İmdi vusûlünde sen ki mîr-i mûmâ ileyhsin bâlâda bast ü beyân olunduğu vechile emânet-i mezkûre iki yüz sekiz senesine mahsûben kapucıbaş1-i mûmâ ileyh ma'rifetiyle idâre ve rü‘yet olunmakdan nâşî meblağ-1 mezbûrun bir gün evvel tahsîl ve mîr-i mûmâ ileyh tarafina irsâl ü tesyîrine mezîd-i ihtimâm ü dikkat eyleyesin ve siz ki kuzât-1 mûmâ ileyhimsiz sizler dahi mûcib-i emr-i şerîfimle 'amel ü hareket eylemeniz bâbında fermân-1 'âlîşânım sâdır olmuştur. Buyurdum ki:

Hükm-i şeriffimle ( ) vardıkda bu bâbda vech-i meşrûh üzere şeref-yâfte-i sudûr olan işbu emr-i şerîf-i celîlü'ş-şân-1 vâcibü’l-imtisâl ve lâzımü'l-ittibâ‘mın mazmûn-1 itâ‘at-makrûnuyla 'âmil olub hilâfından mübâ'adet eyleyesiz. Şöyle bilesiz 'alâmet-i şerîfime i'timâd kılasız. Tahrîren fî'l-yevmi’s-sâbi‘ 'aşer Şevvâl sene 'aşer ve mi'eteyn ve elf.

Bi-makāmı Kostantiniyyeti'l-mahrûsa 
Sira No : 37

Belge No : Adana Ş.S. 56, img. 01, sayfa 01, belge 78-b

Tarih : : 04 Z $1210 / 10$ Haziran 1796

Konu : Adana Mütesellimi Ahmed Bey'in kethüdası Halil Ağa'nın ve Hasanpaşazâde Mustafa Bey’in mühürlerinin zayi olduğuna dair.

Hâlen Adana mütesellimi necâbetlü Hasan Paşazâde Ahmed Bey Hazretlerinin kethüdâ-y1 alî-kadrları silahşör-i şehriyârî Halil Ağa'nın kendi ismine mührü Zilhicce'nin dördüncü günü zâyi’ olduğu kayd şod. Fî 4 Zilhicce sene 210

Hasanpaşazâde sa'âdetlü Mustafa Bey'in kendi ismine mührü Rebî'u'l-ahirin yirmi yedinci yevm-i sebt zâyi‘ olduğu kayd şod. Fî 27 Rebî'i’l-ahire sene 1211 (30 Ekim 1796).

Yine mûmâ ileyh Halil Ağa’nın kendi ismine bir sîm ve bir nühâs mühürleri Rebî‘u'l-ahirin sekizinci günü zâyi‘ olduğu kayd şod. Fî 8 Rebî‘i’l-ahir sene 1211(11 Ekim 1796) 
Sira no : $: 38$

Belge no : BOA, C. ML 781/31892

Tarih : : 6 R 1211 (09 Ekim 1796)

Konu : Adana mukāta ‘asının 1201 senesinden 1210'a kadar birikmiş olan alacaklarından arta kalan 12.500 guruşun toplanmasına dair emir

Mektûbî-i hazret-i sadâret-penâhî hulefâsından me'mûriyetle Adana cânibine gidüb 'avdet eden Mehmed Emin Efendi kullarının getürdüğü evrâkdan bir mâddenin hülâsasıdır. Fî 4 R sene 211.

Adana Mütesellimi Hasanpaşazâde Ahmed Bey ve karındaşları Mehmed Bey ve Mustafa Bey kullarının ber vech-i iştirâk mâlikâne 'uhdelerinde olan Yörügân-1 Adana ve Tarsus ve Sis Mukāta'ası mâlından iki yüz bir senesinden on senesine gelince müctemi' olan mebâliğden gayr-1 ez havâlât ü teslîmât kusûr kalan kırk dört bin üç yüz altmış bir guruşun mîr-i mûmâ ileyhimden tahsîl ve Der-'aliyyeye irsâli bâbında Cabbarzâde Süleyman Bey kullarına hitâben sudûr eden emr-i âlî lede'l-vusûl husûs-1 mezbûr zımnında târîh-i emr-i şerîf-i mezkûrdan sonra ba'zı havâlâta bâ-evâmir-i aliyye i'tâ olunduğundan mâ'adâ iki yüz dokuz senesi mâl-1 mîrîsi tamâmen kabzına me'mûr çukadâr-1 defterî Ebubekir kullarına teslîm ve yedinden sened ahz olunub ve ol vechile iki yüz bir senesinden on senesine gelince bâkî kalan on iki bin beş yüz guruşun dahi ba'zısı kısteyn mevâcibine havâle olunduğuna binâ'en teslîm olunmakda olub lâkin mîr-i mûmâ ileyhim kulları bundan akdem mukāta'a-i merkûmeye dest-rez olamayub mâl-1 mîrîsi telef olmağla bi-mennihi ta'alâ ceste ceste edâ ve teslîm ve senedlerini ahz etmek üzere olmalarıyla mukāta'a-i merkûmenin güzeştesi zımnında tekrâr emr-i âlî ısdârıyla gadrdan himâyet birle imhâl buyurulması niyâzında oldukların Adana kâdîsı i'lâmında ve mütesellim-i mûmâ ileyh 'arzıhalinde tahrîr ederler.

Asl hulâsasina fermân-ı âlî olmuşdur.

Başmuhâsebeden keyfiyeti görüle.

Sen ki mütesellim ve mîr-i mûmâ ileyhsin ber vech-i mâlikâne iştirâken "uhdenizde olan Cemâ'at-i Yörügân-1 Adana ve Tarsus Mukāta'ası re‘âyâsı göçebe ve aşâyir tâ'ifesinden olub mukaddemlerde üzerlerine edâsı lâzım gelen emvâl-i mîriyeyi kable’l-edâ yaylaklarına azîmet eylediklerinden emvâl-i mezkûrenin tahsîli mümkin olunamadığı ecilden tahsîli husûsunda mukaddemen hasbe'l-iktizâ vüzerâ ve mîr-mîrân ve Dergâh-1 Âlî kapucubaşılarından Cabbarzâde Süleyman Bey dâme mecdühuya ihâle olunarak bu seneye gelince eğerçi ihtilâl üzere olub ancak bu def'a re‘âyâ-yı merkûme ile bi'l-mükâtebe fî-mâ ba'd üzerlerine edâsı lâzım gelen mâl-1 mîrîyi vaktiyle teslîm ve sinîn-i güzeşteden kusûr kalan on iki bin dört yüz yetmiş yedi guruşu Eylül duhûlünde edâya ta'ahhüd etmeleriyle bi-mennihi ta'âlâ Eylül duhûlünde siz re'âyâ-y1 merkûmun ta'ahhüdleri vechile meblağ-1 kusûr-1 mezbûru tahsîl ve Der-'aliyyeye irsâle müte'ahhid olduklarınızı Adana kâdîsı i'lâmında ve sen ki mütesellim-i 
mûmâ ileyhsin arzıhalinde tahrîr ve inhâ eylemişsin ancak meblağ-1 mezbûr on iki bin dört yüz yetmiş yedi guruşu bi-mennihi ta âlâ işbu sene-i mübâreke evâsıt-1 Cemâziye'l-ûlâsında ihrâc ve tevzî'i musammem olan bir kıst mevâcibe tertîb ve tahsîs k1lınmak hasebiyle meblağ-1 mezbûru tamâmen tedârük ve ta'yîn olunan mübâşir-i merkûma teslîmen ihrâc-1 mevâcibden mukaddem Der-sa'âdete irsâl ve Hazîne-i Âmireme teslîm eder iseniz fe-bihâ ve illâ bundan sonra dahî irsâlinde tereddüd eylediğiniz sûretde mukāta'a-i merkûm cânib-i mîrîden zabt ve mâl-1 mîrîsinden zimmetiniz istîfâ oluncaya değin beher sene mûmâ ileyh Cabbarzâde'ye ihâle olunarak istîfâ-yı deyn etdirilmek fermân olunmağın mûcebince fî̀ 16 M sene 1211 târîhinde Adana kâdîsına ve mukāta'a-i mezbûr mutasarrıflarından hâlen Adana Mütesellimi Ahmed Bey ve Adana sâkinlerinden Mehmed Bey ve Mustafa Bey zîde mecdühum ve bu husûs içün bu def'a mübâşir tayîn olunan ( ) zîde kadrühuya hitâben emr-i şerîf verildiği mukayyeddir.

Ve mukāta‘a-i mezbûrun iki yüz bir senesinden iki yüz dokuz senesine gelince iktizâ eden mâl-1 mîrîsinden gayr-1 ez teslîmât kusûr kalan aslı dokuz bin yedi yüz altmış sekiz guruşun tahsîli bâbında mukaddemen emr-i âlî-şân ısdâr ve irsâl olundukda mukāta'a-i mezbûre re'âyâları cebel-i şâhikada olmalarıyla takrîbiyle üzerlerine edâsı lâzım gelen mâl-1 mîrînin edâsında mümâna 'at eylediklerine binâ'en iki yüz bir senesinden iki yüz beş senesine gelinceye değin iktizâ eden otuz beş bin beş yüz elli guruşun tahsîli husûsunu sen ki mîr-i mûmâ ileyhsin mukaddemen senin 'uhdene ihâle ve tefvîz kılınmakdan nâşî re'âyâ-yı merkûm mebâliğ-i mezkûreyi tarafina edâ ve teslîm eylediklerinden bahsle ta'allül ve muhâlefet eyledikleri inhâ olunub ancak mebâliğ-i mezkûreden kusûr ${ }^{84}$ on dört bin yedi yüz elli guruş ma'rifetinle tahsîl ve Hazine-i Âmireye teslîm olunmuş olmağla kusûr kalan yirmi bir bin sekiz yüz guruş re‘âyây1 merkûm zimmetlerinde pes-mânde kaldığı zâhir iken bu makûle a'zâra teşebbüs ile ta'allül ve muhâlefet eylemeleri mücerred zimmetleri olan meblağ-1 mezbûru vermemek dâ'iyyesine mebnî olmağla meblağ-1 kusûr-1 mezkûr yirmi bir bin sekiz yüz guruş bi-mennihi ta'âlâ işbu sene-i mübâreke Cemâziye'l-ûlâda ihrâc ve tevzî‘i musammem olan bir kıst mevâcibe tertîb ve tahsîs kılınmakdan nâşî meblağ-1 mezbûru aşâyir-i merkûmeden ma 'rifetinle tamâmen tahsîl ve mübâşir-i mûmâ ileyhe teslîmen ihrâc-1 mevâcibden mukaddem Der-sa'âdete irsâl ve Hazîne-i Âmireye teslîme ihtimâm ü dikkat eylemen fermân olmağın mukāta'a târîh-i merkûmeden Dergâh-1 Âlî kapucubaşılarından mîrâhûr-1 evvel pâyesiyle Bozok Sancağı Mutasarrıfı Cabbarzâde Süleyman Bey dâme mecdühuya ve bu def'a mübâşir ta 'yîn olunan ( ） zîde kadrühuya hitâben dahi emr-i şerîf verildiği mukayyeddir. Fermân devletlü inâyetlü sultânım hazretlerinindir.

Fî 6 R sene 1211. Sahh.

Isti 'câllerini muhtevî Cabbarzâde’ye hitâben mü 'ekked evâmir-i şerîfe tahrîr oluna 
Sira No : 39

Belge No : BOA, C. Dahiliye 17063-B ${ }^{85}$

Tarih : :25 Receb 1211/24 Ocak 1797

Konu : Adana'da Hasanpaşâdeler ve Menemencioğulları zimmetlerinde kalan devlet alacağının tahsili konusunda Bozok Mutasarrıfı Çaparzâde Süleyman Bey’in arîzası.

Hüve

Devletlü inâyetlü âtufetlü re'fetlü vüfûrü'l-kerem efendim sultânım hazretleri

Lâzıme-i zimmet-i bendegâne ve râtib-i ûhde-i çâkerânem olan istidâme-i eyyâm-1 ömr ü devlet ve ikbâl ü iclâlleri du'âvâtı te' diye ve tatmîm k1lındığı zeylinde ma'rûz-1 bende-i kadîmleridir ki:

Adanalı Hasanpaşazâde Ahmed Bey ve karındaşları Mustafa Bey ve Mehmed Bey’in ber vech-i mâlikâne iştirâken 'uhdelerinde olan Cemâ'athâ-yı Yörügân-1 Adana ve Tarsus Mukāta 'ası re‘âyâlarının zimmetlerinde bâkî kalan ma'lûmü'l-mikdâr mâl-ı bakāyālarının ve Adana vâlisi esbak Ata“ullah Paşa'nın cânib-i mîrîden zabt olunan zimemâtından Melemenci aşiretleri zimmetlerinde olan on bin guruşun tahsîli bâbında taraf-1 bendelerine ve Adana kâdîsına hitâben sâdır olan evâmir-i şerîfe sadr-1 a'zam ve bedr-i efham devletlü inâyetlü merhametlü veliyyü’n-ni'am efendimiz hazretlerinin çukadârlarından izzetlü Mehmed Ağa mübâşeretiyle şerf-rîz-i vürûdunda yanına mukaddim adamım kulları terfik ve Adana’ya irsâl olunub, Melemenci aşiretinden matlûb buyurulan on bin guruşun beş bin guruşu hâh (ü) nâ-hâh tahsîl ve mübâşir-i mûmâ ileyhe teslîm ve Der-aliyye'ye ba's ü tesyîr olunduğundan gayri Yörügân-1 mezkûrenin bakāyāsı dahi (mîr)mîrân-1 merkûmûndan matlûb eylediklerinde hadâset-i sinnleri takrîbiyle bakâ(yâ)-yı mezkûre cevâbını dahi etmeyüb mübâşir-i mûmâ ileyh tehî avdet etmeleriyle hâl ü keyfiyyetleri ne vechile olduğu mübâşir-i mûmâ ileyh kullarının takrîrinden ma'lûm-1 inâyetleri buyurulmak iltimâsı arîza-i inâyetleri buyuruldukda ol bâbda lutf ü kerem devletlü inâyetlü atûfetlü re'fetlü vüfûrü'l-kerem efendim sultânım hazretlerinindir.

Fî 25 B sene 1211.

(Mühür: El-müste‘âni’l-1lâhi himmet Süleymân)

İzzetlü Defterdâr Efendi, meblağ-1 mezbûru ahz ve mahalline teslîm ve iktizâsını ifâde eylemeniz fermân buyuruldu. 
Sira No : : 40

Belge No : Adana Ş.S. 55, img. 78, sayfa 153 belge 13

Tarih : Evail L 1211 / 30 Mart-8 Nisan 1797

Konu : Adana Eyaletinin Rum Beylerbeyisi ve İsmail Muhafizı Mehmed Paşa’ya verildiğine ve Ahmed Bey’in mütesellim tayin olunduğuna dair.

Mefâhirü'l-kuzât ve'l-hükkâm ma‘denü'l-fazlı ve'l-kelâm Mevlânâ Adana kâdîsı ve Adana eyâletinde vâkı' kazâların kuzât ve nüvvâbı zîde fazluhum tevkî‘-i refî'-i hümâyûn vâsıl olıcak ma'lûm ola ki:

Bu def'a Adana eyâleti İsmail muhâfızı olub Rum Beylerbeyisi pâyesi olan mutasarrıf-1 sâbık emirü'l-ümerâ'i'l-kirâm Mehmed Paşa dâmet me'âlühuya kal'a-i mezbûre muhâfazası şartıyla 'avâtıf-1 'aliyye-i şâhâne ve 'avârıf-1 behiyye-i tâcdârânemden işbu bin iki yüz on bir senesi Şevvâlü'l-mükerremin dördüncü gününde tevcîh ve ihsân-1 mülûkânem olub paşa-yı mûmâ ileyhe kal'a-1 merkûme muhâfazasında olmak takrîbiyle tarafindan Adana eyâletine zabt ü rabt-1 memleket ve re'y ve himâyet ü siyânet-i fukarâ ve zu'afâya muktedir bir mütesellim nasbından lâbüd ve muktezî olmakdan nâşî Adana kazâsı sükkânından El-hâcc Abdullahpaşazâde kıdvetü'l-emâcid ve'l-a'yân Ahmed Bey zîde mecdühu evsâf-1 mezkûra mevsûf ve re'âyâ-perver ve müstakîmü’l-etvâr olduğundan bahisle eyâlet-i mezkûreye mütesellim nasb olunmak bâbında emr-i şerîf sudûrunu paşa-yı mûmâ ileyhin kapu kethüdâsı bâ-takrîr istid'â itmekle vech-i meşrûh üzere mütesellim nasb olunmak fermânım olmağın imdi siz ki mevlânâ-y1 mûmâ ileyhimsiz mîr-i mûmâ ileyh eyâlet-i mezkûreye mütesellim nasb ü ta'yîn k1lındığı ma'lûmunuz oldukda ber vech-i muharrer mütesellilik-i mezkûru târîh-i merkûmdan mîr-i mûmâ ileyhe zabt ve paşa-yı mûmâ ileyh tarafina râci' olan 'â'idât ve tayyârâtı kadîmden olugeldiği vechile ahz ü kabz itdirüb mütesellimliği umûruna aherden bir ferdi dahl ü ta ‘arruz itdirilmemek bâbında fermân-1 'âlîşânım sâdır olmuşdur. Buyurdum ki:

Hükm-i şerîfimle vusûl buldukda bu bâbda vech-i meşrûh üzere şeref-yâfte-i sudûr olan fermân-1 vâcibü'l-ittibâ' ve lâzımü'l-imtisâlimin mazmûn-1 itâ'at-makrûnuyla 'amel ü hareket ve hilâfından gâyetü'l-gâye tehâşî ü mücânebet eyleyesiz. Şöyle bilesiz 'alâmet-i şerîfe i'timâd kılasız. Tahrîren fî̀ evâ'ili şehri Şevvâli'l-mükerrem sene ihdâ 'aşer ve mi'eteyn ve elf.

Bi-makāmı Kostantiniyyeti'l-mahrûse. 
Sira No : 41

Belge No : Adana Ş.S. 55, img. 11, sayfa 21, belge 212

Tarih : : 14 L $1211 / 12$ Nisan 1797

Konu : Adana'nın devlet gelirlerinden tahsil edilemeyip kalmış olan 114.430 kuruşun elbirliği ile yerlü yerinden tahsîl ve İstanbul'a gönderilmesine dair ferman.

Mefâhirü'l-kuzât ve'l-hükkâm me‘âdinü'l-fezâ‘il ve'l-kelâm Adana eyâletinde vâk1‘ zikr-i âtî mukāta'âtın muhtevî olduğu kazâların kâdîları ve nâ'ibleri zîde fazluhum ve kıdvetü'l-emâcid ve'l-a'yân hâlen Adana Mütesellimi Ahmed Bey zîde mecdühu ve mefâhirü'l-emâsil ve'lakrân vücûh-1 ahâli ve iş erleri ve bu husûsa hâsseten mübâşir ta 'yîn olunan defterdâr-1 şıkk-1 evvelim etbâ''ndan Hacı Mehmed zîde kadrühu tevkî'-i refî'-i hümâyûn vâsıl olıcak ma'lûm ola ki:

Mukāta'ât-1 mîriyyeye mutasarrıf olanlar mukayyed olan mâlın beher sene hazîne-i 'âmireme havâle olunan mahallere edâ ve kalemiyyesin virüb hesâbın görmek şurût-1 mâlikâneden iken kaleminden ihrâc ve derûn-1 emr-i şerîfime mevzû'an irsâl olunan sûret-i defterde muharrer mukāta'âtın bir müddetden berü mâl-ı mîrileri pes-mânde kaldığından tahsîli içün emr-i şerîfim 1sdâr olundukca Adana'nın perîşânlığından cevâb virilerek sinîn-i güzeşteden gayr-1 ez havâlât ü teslîmât mukāta'ât-1 merkûmenin el-yevm bir yük on dört bin dört yüz otuz buçuk guruş mâlı bekāyā kalmağla meblağ-1 mezbûr vâridât-1 mukarrere-i mîriyyeden olub bir akçasının pes-mânde kalması tecvîz olunur hâlâtdan olmadığına binâ'en siz ki mütesellim ve vücûh-1 ahâli-i mûmâ ileyhim ve iş erlerisiz işbu emr-i şerîfimle ta'yîn olunan mübâşir lede'l-vusûl meblâğ-1 mezbûr mukāta'ât ashâbından ve zabt iden mültezimlerinden ve hâsılât-1 mukāta'âtdan ve fevt olanların terekelerine vâzı'ü'l-yed olan vereselerinden ve îcâb ü iktizâ idenlerden ma'rifetiniz ve ma'rifet-i şer' ve cümle ittifâkıyla tamâmen tahsîl ve mukāta'ât-1 merkûmeden harâb olmuşları var ise tagallüb ve ta'ayyün kesb itmek içün harâbî-i memlekete bâ'is olanlardan tazmîn eylemeniz iktizâ itmekle o makûle harâb mukāta'atın mâlları ne mikdâr ise tahrîb-i memlekete bâ'is olanlardan tazmîn olunmak içün keyfiyeti i'lâma mübâderet ve mâ'adâsının bir akçası girüye kalmayarak yerlü yerinden tahsîl ve mübâşir-i merkûma teslîm ve Der-sa'âdetime tesyîri husûsuna müsâra'at eylemeniz fermânım olmağın hâsseten işbu emr-i 'âlîşânım sâdır ve mübâşir-i merkûm ile irsâl olunmuşdur. İmdi vusûlünde sûret-i defterde terkîm olunan mukāta 'âtın sinîn-i güzeşte emvâlinden müterâkim olan meblağ-1 mezbûru fermânım olduğu vechile mukāta'ât-1 merkûm ashâbından ve zabt iden mültezimlerinden ve hâsılât-1 mukāta'âtdan ve fevt olanların terikelerine vâzı'ü'l-yed olan vereselerinden ve îcâb ü iktizâ idenlerden ma'rifetiniz ve ma'rifet-i şer' ve cümle ittifâkıyla tamâmen tahsîl ve mukāta ât-1 merkûmeden harâb olmuşları var ise tagallüb ve ta'ayyün kesb itmek içün harâbî-i memlekete bâ'is olanlardan tazmîn eylemeniz iktizâ eylediği ma'lûmunuz oldukda o makûle harâb mukāta'âtın mâlları ne mikdâr ise tahrîb-i memlekete bâ‘is olanlardan tazmîn olunmak içün keyfiyeti i'lâma mübâderet ve mâ'adâsının bir akçası girüye kalmayarak tekmîlen yerlü 
yerinden tahsîl ve mübâşir-i merkûma teslîm ve Der-sa'âdetime tesyîri husûsuna müsâra'at ve hilâfından mübâ'adet eyleyesiz ve sen ki mübâşir-i merkûmsun işbu emr-i şerîfimle Adana’ya varub sâlifü'z-zikr bir yük on dört bin dört yüz otuz buçuk guruş mâl-1 mîrî bekāyāsını fermânım olduğu üzere cümle ittifâkıyla yerlü yerinden tahsîl ve pey-der-pey hazîne-i 'âmireme teslîme ihtimâm ü dikkat ve lâzımü'l-inhâ husûsâtı sen dahi tahrîr iderek tahsîl-i emvâl-i mîriyyeye sa'y ü gayret ve kusûr ü rehâvetden mücânebet eyleyesin ve siz ki kuzât ve nüvvâb-1 mûmâ ileyhimsiz siz dahi muktezâ-yı emr-i şerifime imtisâl ve mütâba'at eylemeniz bâbında fermân-1 'âlîşânım sâdır olmuşdur. Buyurdum ki:

Hükm-i şerîfimle ( ） vardıkda bu bâbda vech-i meşrûh üzere şeref-yâfte-i sudûr olan işbu emr-i şerîf-i celîlü'ş-şân-1 vâcibü'l-ittibâ' ve lâzımü'l-imtisâlimin mazmûn-1 münîfi üzere 'âmil olub hilâfından hazer ü mücânebet eyleyesiz. Şöyle (bilesiz) 'alâmet-i şerîfe i'timâd kılasız. Tahrîren fî‘l-yevmi’r-râbi ‘i 'aşer şehri Şevvâl sene ihdâ 'aşere ve mi ‘eteyn ve elf.

Bi-makāmı Kostantiniyyeti'l-mahrûse

Hazret-i defterdâr-1 şıkk-1 evvel etbâ‘'1ndan El-hâcc Mustafa zîde kadrühu ile isti ‘câl(i) hâvî bir kıt'a fermân-1 'âlîşân sâdır ve vürûd eylediği bu mahall(e) kayd şod. 
Sira No : : 42

Belge No : Adana Ş.S. 55, img. 79, sayfa 154, belge 11

Tarih : :07 ZA $1211 / 04$ Mayıs 1797

Konu : : Adana Mütesellimi Hasanpaşazâde Ahmed Bey, Mehmed Bey ve Mustafa Bey’in uhdelerinde olan Cemaâthâ-i Yörügân-1 Adana ve Tarsus mukāta'asının 1210 senesi gelirlerinden Akkirman Kal'ası muhâfızlarına havâle olunan 2.500 kuruşun görevli kişi tarafından alındığına dair.

Bâ‘is-i tastîr-i hurûf budur ki:

Hâlen Adana Mütesellimi Hasanpaşazâde necâbetlü Ahmed Bey ve Mehmed Bey ve Mustafa Bey Hazretlerinin 'uhdelerinde olan cema 'âthâ-i Yörügân-1 Adana ve Tarsus ve Sis Mukāta'asının bin iki yüz on senesi mâl-1 mirîsinden bâ-emr-i 'âlî Akkirman Kal'ası muhâfazasında olan muhâfızlarına havâle olunan iki bin beş yüz guruşa me'mûriyetim ve mübâşeretim hasebiyle mîr-i mûmâ-ileyhim hazerâtından tamâmen ve kâmilen ahz ü kabz idüb cânib-i hazîne-i 'âmireye îsâl ve teslîm zımnında 'indimde hıfz olmağla meblağ-1 mezbûru ahz ü kabz eylediğimi müş 'îr işbu tahvîl tahrîr ve mîr-i mûmâ ileyhim yedlerine li-ecli’s-sened i'tâ olundu. Gerekdir ki hîn-i hâcetde ibrâz ve ihticâc oluna ve's-selâm. Hurrire fî̀ 7 Zi'l-ka'de sene 1211

El-fakîr Ali Bozoklu Çukadâr-1 Hazret-i izzetlü defterdâr-1 sâni 
Sira No : 43

Belge No : Adana Ş.S. 55, img. 12, sayfa 22, belge 211

Tarih : : 18 ZA $1211 / 8$ May1s 1797

Konu : Hasanpaşazâde Ahmed, Mehmed ve Mustafa Bey’in malikane olarak uhdelerinde olan Yörügan-1 Adana ve Tarsus ve Tevabii Mukāta'ası'nın 1208 senesinden 1211 senesine gelince birikmiş olan 3.543,5 guruş otuz akçanın tahsil edilmesine dair.

Kıdvetü'l-kuzât ve'l-hükkâm ma'denü’l-fazlı ve'l-kelâm Mevlânâ Adana kâdîsı zîde fazluhu ve kıdvetü'l-emâcid ve'l-a'yân Adana Mütesellimi Ahmed Bey zîde mecdühu ve kıdvetü'l-emâsil ve'l-akrân bu husûsa mübâşir ta 'yîn olunan defterdâr-1 şıkk-1 evvelim etbâ 'indan El-hâcc Mehmed zîde kadrühu tevkî'-i refî‘-i hümâyûn vâsıl olıcak ma'lûm ola ki:

Zamân-1 zabtı Mart evvelinden olub Adana sâkinlerinden Karslızâde Hasanpaşa hafîdleri Mustafa Bey ve Mehmed ve Ahmed Bey zîde mecdühumun ber vech-i mâlikâne 'uhdelerinde olan Yörügân-1 Adana ve Tarsus ve Tevâbi‘i Mukāta 'ası'nın bin iki yüz sekiz senesinden iki yüz on bir senesine gelince ber mûceb-i mu'tâd-ı kadîm iktizâ iden kalemiyyesinden iftihârü'l-ümerâ' ve'l-ekâbir müstecmi'-i cemî'u'l-me'âlî ve'l-mefâhir el-muhtassu bi-mezîdi 'inâyeti'l-meliki'l-kâdir bi'l-fi'il başdefterdârım El-hâcc İbrahim Reşid dâme 'uluvvuhunun hissesine isâbet iden ma'a harc-1 aklâm yalnız bin üç yüz kırk beş buçuk guruş otuz akça kalemiyyesi mu'accelen tahsîl ve müşârun ileyhin hazînesine teslîmi mühimm ve muktezî olmağın hâssaten işbu emr-i celîlü'l-kadrım 1sdâr ve mübâşir-i merkûm ile irsâl olunmuşdur. İmdi vusûlünde kaleminden ihrâc derûn-1 emr-i şerîfime mevzû'an irsâl olunan imzâlu sûret-i defterde takdîm olunduğu üzere ol mikdâr kalemiyye akçasını siz ki kâdî ve mütesellim-i mûmâ ileyhimsiz ma'rifetiniz ile yerlü yerinden tamâmen ve kâmilen tahsîl ve mübâşirine teslîmen serî‘an ve 'âcilen Der-'aliyyeme irsâl ve defterdâr-1 müşârûn ileyhin hazînesine teslîme mezîd-i ihtimâm ü dikkat eyleyesiz. Şöyle ki zikr olunan kalemiyye akçasının tahsîli pesmânde-i ‘ukde-i te'hîr olunduğuna bir dürlü rıâ-y1 şâhânem olmamağla derûn-1 emr-i şerîfimde dakîka-i vâhide te'hîr ve tevakkufa ruhsat ve cevâz göstermeksizin tamâmen ve kâmilen mûmâ ileyhden tahsîl ve Der-'aliyyeme tesyîr birle hazîne-i müşârun ileyhe tavsîline ziyâde sa'y ü gayret eyleyesiz ve sen ki mübâşir-i merkûmsun işbu emr-i şerîfimle ol tarafa vusûlünde me'mûr-1 tahsîli olduğun mezkûrü'l-mikdâr kalemiyyesini ma'rifet-i şer' ve mütesellim-i mûmâ ileyhin ma'rifeti ve ma'rifet ve mübâşeretinle mûmâ ileyhden tamâmen ve kâmilen taleb ve tahsîl ve temessük i'tâsıyla getürüb müşârun ileyhin hazînesine îsâl ve teslîme sür'at ü şitâb ve avk ü te'hîr ile imrâr-1 vaktden tehâşî ü ictinâb eylemen bâbında fermân-1 'âlîşânım sâdır olmuşdur. Buyurdum ki:

Hükm-i şerîfimle ( ） vardıkda bu bâbda vech-i meşrûh üzere şeref-yâfte-i sudûr olan işbu emr-i şerîf-i celîlü'ş-şân-1 vâcibü'l-imtisâl ve lâzımü'l-ittibâ'1mın mazmûn-1 münîfi üzere 'amel ü hareket ve hilâfindan gâyetü'l-gâye ittikâ ü mübâ'adet eyleyesiz. Şöyle bilesiz; 'alâmet-i şerîfe i'timâd kılasız. Tahrîren fi'l-yevmi's-sâmin 'aşer Zi'l-ka'de sene ihdâ 'aşere ve mi'eteyn ve elf.

Bi-makāmı Kostantiniyyeti'l-mahrûse. 
Sira No : 44

Belge No : Adana Ş.S. 55, img. 11, sayfa 20, belge 213

Tarih $\quad$ : 14 ZA $1211 / 11$ May1s 1797

Konu : Adana cizyesinin 1212 senesine mahsûben 13.000 kuruşa Ahmed Bey’e sipariş edildiğine ve Ahmed Bey’in cizye geliri mevâcibe tahsis edilmiş olan 1.500 kuruş ile 391,5 kuruş harc-1 aklâm ve diğer aidatlarını İstanbul'a yollamasına dair ferman.

Kıdvetü'l-kuzât ve'l-hükkâm ma'denü'l- fazlı ve'l-kelâm Mevlana Adana kâdîsı zîde fazluhu ve k1dvetü’l emâcid ve'l-a‘yân Adana Mütesellimi Ahmed Bey zîde mecdühu ve kıdvetü'l-emâsil ve'l-akrân bu husûsa mübâşir ta'yîn olunan defterdâr-1 şıkk-1 evvelim etbâ' 1ndan El-hâcc Mehmed zîde kadrühu tevkî‘-i refî‘-i hümâyûn vâsıl olıcak ma'lûm ola ki:

Adana cizyesinin gayr-1 ez ma'âş fî'l-asl yirmi beş bin üç yüz yetmiş sekiz guruş mâlı olub ancak el-hâletü hâzihi hâsılatı mâl-1 mukayyedi mikdârına bâliğ olmayacağı tashîh olunmağla bi-mennihi ta‘âlâ bundan böyle tanzîmine dikkat birle mâl-1 aslîsine iblâğ olunmak şartıyla sen ki mütesellim-i mûmâ ileyhsin gayr-1 ez ocaklık menzil işbu bin iki yüz on bir senesine mahsûben zikr olunan Adana cizyesi iltimâsına binâ'en on üç bin guruşa maktû'an 'uhdene ihâle ve tefvîz olunmuşidi. Şimdi bin iki yüz on iki senesine mahsûben dahi cizye-i mezkûr sâbıkı üzere hazîne-i 'âmirem defterlerinde 'uhdene kayd ve berât ve evrâk boğçası mübâşir-i merkûm ma'rifetiyle tarafına irsâl olunmağla vusûlünde boğça-yı merkûmeyi ahz ve gurre-i Muharremü'l-harâmda ma'rifet-i şer'le mührünü fekk ü küşâd ve kalem-i mezbûr ve tevâbi'inde sâkin ve mevcûd yerlü ve yabancı ve mürûr (ü) 'ubûr eden ehl-i zimmetin esnâf-1 selâse üzere hâl ve tahammüllerine göre 'ale'r-ru'us evrâkları tevzî' ve iktizâ eden mâl-1 cizyeleri cânib-i mîriçün cibâyet ve tahsîline şürû' ve mübâşeret birle evvel-be-evvel tahsîl ve makbûzun olan mâl-1 cizyeden divân-1 müşeyyedü'l-erkân-1 mülûkânemde ihrâcı musammem olan kapum kulları mevâciblerine müretteb bin beş yüz guruş peşîn akçesiyle kaleminden muhrec mümzâ sûret-i defterde terkîm olunan üç yüz doksan bir buçuk guruş harc-1 aklâm ve avâ'id-i sâ'ireyi mübâşir-i merkûma teslîmen Der-'aliyyeme irsâl ü tesyîr eylemen fermânım olmağın işbu emr-i 'âlîşânım 1sdâr ve mübâşir-i merkûm ile irsâl olunmuşdur. İmdi vusûlünde bâlâda zikr olunduğu üzere cizye-i mezkûr bin iki yüz on iki senesine mahsûben gayr-1 ez ocaklık menzil sâbık1 üzere on üç bin guruşa maktû'an 'uhdene kayd ü berât ve evrâk boğçası tarafina irsâl olunmuş olduğu ma'lûmun oldukda sene-i merkûma mahsûben kalem-i mezbûr ve tevâbi'inde sâkin ve mevcûd ve mürûr (ü) ubûr eden ehl-i zimmetin esnâf-1 selâse üzere hâl ve tahammülerine göre 'ale'r-ru'us evrâkları tevzî‘ ve iktizâ eden mâl-1 cizyelerinin cibâyet ve tahsîline şürû' ve mübâşeret birle evvel-be-evvel tahsîl eylediğin mâl-1 cizyeden mevâcibe müretteb bin beş yüz guruş peşîn akçasıyla üç yüz doksan bir buçuk guruş harc-1 aklâm ve avâ'id-i sâ'ireyi mübâşir-i merkûma teslîmen Der-'aliyyeme irsâl ü tesyîre müsâra'at eyleyesin. Şöyle ki mevâcib-i mezkûrun beher hâl ihrâcı bu makûle mürettebâtın vaktiyle gelüb teslîm-i hazîne-i 'amirem olunmasına mütevakkıf ve menût olmağla hemân meblağ-1 mezbûru tedârük ve hazîne-i 'ami- 
reme ve mahallerine edâ ve teslîme mübâderet ve sen ki mübâşir-i merkûmsun me'mûr-1 îsâli olduğun berât ve evrâk boğçasını mashûben bi’s-selâm mütesellim-i mûmâ ileyhe teslîm ve mevâcibe müretteb sâlifü'z-zikr bin beş yüz guruş peşîn akçesiyle sûret-i defterde terkîm olunan harc-1 aklâmı mütesellim-i mûmâ ileyhden ahz ve seyr-i serî‘ ile ihrâc-1 mevâcibden mukaddem getürüb hazîne-i âmireme ve mahallerine edâ ve teslîme dikkat ve esnâ-y1 râhda me'mûriyetinde bilâ mûcib mahallinde meks ü ikāmetden mücânebet ve sen ki kâdî-i mûmâ ileyhsin sen dahi mûcib-i emr-i şerîfimle 'amel ü hareket eylemeniz bâbında fermân-1 'âlîşânım sâdır olmuşdur. Buyurdum ki:

Hükm-i şerîfimle ( vardıkda bu bâbda vech-i meşrûh üzere şeref-yâfte-i sudûr olan işbu emr-i şerîf-i celîlü'ş-şân-1 vâcibü'l-imtisâl ve lâzımü'l-ittibâ‘mın mazmûn-1 münîfi üzere 'amel ü hareket ve hilâfiyla vaz' ü hâlât vukû'unda be-gâyet mübâ'det eyleyesiz. Şöyle bilesiz 'alâmet-i şerîfe i'timâd kılasız. Tahrîren fi'l-yevmi'r-râbi' 'aşer Zi'l-ka'de sene ihdâ 'aşere ve mi'eteyn ve elf.

Bi-makāmı Kostantiniyyeti'l-mahrûse. 
Sira No : : 45

Belge No : Adana Ş.S. 55, img. 10, sayfa 18, belge 215

Tarih : : $18 \mathrm{~S} 1212 / 12$ Ağustos 1797

Konu : Ahmed, Mehmed ve Mustafa Beylerin uhdelerinde olan Cemaatha-i Yörügan-1 Adana ve Tarsus ve Sis Mukāta'asının 1201 senesinden 1210 senesine gelince zimmetlerinde birikmiş olan 29.712 guruşu on bir senesinden itibaren senede beşer bin guruş taksite bağlanıp mukāta'anın yıllık geliri olan $10.177,5$ ve bin iki yüz on bir senesi taksiti olan 5.000 guruşun devlet hazinesine teslim edilmesine dair ferman.

Kıdvetü'l-kuzât ve'l-hükkâm ma'denü'l-fazlı ve'l-kelâm Mevlânâ Adana kâdîsı zîde fazluhu ve kıdvetü'l-emâcid ve'l-a“yân Adana Mütesellimi Ahmed Bey zîde mecdühu ve kıdvetü'l-emâsil ve'l-akrân defterdâr-1 şıkk-1 evvelim etbâ'ından bu husûsa mübâşir ta ‘yîn olunub ol cânibde olan El-hâcc Mehmed zîde kadrühu tevkî'-i refî'-i hümâyûn vâsıl olıcak ma'lûm ola ki:

Sen ki mütesellim-i mûmâ ileyhsin zamân-1 zabtı Mart ibtidâsından olub senin ve birâderlerin Mehmed Bey ve Mustafa Bey zîde mecdühumânın ber-vech-i mâlikâne 'uhdenizde olan Cemâ'athâ-i Yörügân-1 Adana ve Tarsus ve Sis Mukāta'ası'nın bin iki yüz bir senesinden on senesine gelince mukayyed olub mâlından gayr-1 ez teslîmât ve havâlât zimmetinizde terâküm iden yirmi dokuz bin yedi yüz on iki guruşu on bir senesinden i'tibâren senede beşer bin guruş taksîte rabt olunub mukāta'a-i mezbûrenin ma'a tefâvüd-i şemsiyye bin iki yüz on bir senesi mâlı olan on bin yüz yetmiş yedi buçuk guruş asıl akça mâlını bi’t-tamâm edâ eylemeniz şartıyla tarafınıza sûret i'tâ ve bin iki yüz on bir senesi mâlı olan meblağ-1 mezbûru on bin yüz yetmiş yedi buçuk guruş asl akça ile on bir senesi taksîti olan beş bin guruşun tamâmen tahsîl ve hazîne-i 'âmireme teslîmiçün sene-i sâbıka evâsıt-1 Şa ‘bân'ında başka ve ba'dehu te'kîd ve isti'câli muhtevî sene-i merkûme evâsit-1 Şevvâlinde başka evâmir-i şerîfim 1sdâr ve irsâl olunmuşidi. Şimdi sadr-1 a'zamım çukadârlarından Bozoklu Ali zîde kadrühu ile Der-sa'âdetim'e irsâl eylediğin tahrîrât mefhûmunda on bir senesi taksîti olan beş bin guruşdan iki bin beş yüz guruşunu mübâşir-i merkûma teslîmen irsâl birle diğer iki bin beş yüz guruşunu dahi Haziran duhûlünde irsâl ideceğini ve on bir senesi mâlı olan meblağ-1 mezbûru dahi mukaddemen 'aşâir ile mukâvele olunduğu vechile yaylaklarından 'avdetlerinde Eylül duhûlünde tahsîl ve tesyîr ideceğini sen 'arzıhâlinde tahrîr ü inhâ ve Adana kâdîsından aldığın i'lâmı ( ) eylemişsin zikr olunan mâl-1 mîrinin inhâ ve istid‘ân üzere taksîte rabtı vakt ü zamânıyla edâ olunmak irâdesine mebnî ve on bir senesi mâlı olan meblağ-1 mezbûru dahi tekmîlen edâ eylemen şurûtuna mebnî iki yüz on bir senesi taksîtinin nısfinı getürüb nısfinı dahi Haziran'da edâ iderim ve on bir senesi tekmîl mâlı olan meblağ-1 mezbûru dahi Eylül'de 'aşâ'irin 'avdetlerinde irsâl iderim deyü çukadâr-1 merkûmu i‘âde eylemen tamâm-1 rıâ-y1 şâhânemin hilâfı ve ta'ahhüdüne münâfî olub merâmın bî-hûde tahrîrât ile imrâr-1 vakt idüğü ihsâs olunduğuna binâ'en mukāta'a-i mezbûre üzerinden ref' ve tâlibine fürûht ve zimmet-i mîriyyen def'aten 
tahkîk ve şiddetle tahsîl olunmak lâzım gelmiş ise dahi bu def a tenbîh ile iktifâ ve bundan sonra dahi on bir senesi taksîtinden gayr-1 ez teslîm bâkî kalan iki bin beş yüz guruş ve on bir senesi tekmîl mâlı olan on bin yüz yetmiş yedi buçuk guruş ki cem'an on iki bin altı yüz yetmiş yedi buçuk guruşu mukaddem ta'yîn olunan mübâşir-i merkûma teslîmen irsâl itmez isen muktezâ-y1 te'dîbin icrâsı tasmîm-kerde-i şâhânem idüğü ma'lûmun oldukda vusûl-1 emr-i şerîfimde meblağ-1 mezbûru tamâmen mübâşir-i merkûma teslîmen hazîne-i 'âmireme irsâle ihtimâm ü dikkat ve hilâfından be-gâyet tehâşî ü mücânebet eylemen fermânım olmağın tenbîhen ve isti'câlen işbu emr-i 'âlîşânım ısdâr ve ( ) ile irsâl olunmuşdur. İmdi vusûlünde meblağ-1 mezbûrun vakt-i edâsı mürûr itmekden nâşî bundan sonra bir gün te'hîrine rızâ-y1 şâhânem olmayub tamâmen hazîne-i 'âmireme teslîmi matlûb-1 şâhânem idügü ve fermûde-i hümâyûnumun hilâfi hareket ider isen muktezâ-yı te'dîbin icrâ olunacağı meczûmun oldukda meblağ-1 mezbûru 'alâ eyyi hâlin tamâmen tedârük ve mübâşir-i merkûma teslîmen Der-sa'âdetim'e irsâle ihtimâm ü dikkat ve hilâfı hareket ile mazhar-1 gazab olmakdan nefsini siyânet eyleyesin ve sen ki mübâşir-i merkûmsun me'mûr-i tahsîli olduğun sâlifü’z-zikr on iki bin altı yüz yetmiş yedi buçuk guruşu ma'rifet-i şer'le tamâmen 'alâ eyyi hâlin mütesellim-i mûmâ ileyhden ve birâderlerinden tahsîl ve ahz ve istishâb ve i'câleten getürüb hazîne-i 'âmireme teslîme mezîd-i sa'y ü gayret ve eğer mütesellim-i mûmâ ileyh bugün yarın edâ iderim deyü leyte ü le‘alle ider ise keyfiyeti Der-sa‘âdetim'e tahrîr ü inhâya mübâderet ve bî-hûde meks ü tevkîfden ve tehî dest avdet itmekden ziyâde hazer ü mücânebet eyleyesin ve sen ki kâdı-i mûmâ ileyhsin sen dahi mûcib-i emr-i şerîfimle 'amel ü hareket eylemen bâbında fermân-1 'âlîşânım sâdır olmuşdur. Buyurdum ki hükm-i şerîfimle ( ) vardıkda bu bâbda vech-i meşrûh üzere şeref-yâfte-i sudûr olan işbu emr-i şerîf-i celîlü'ş-şân-1 vâcibü'l-ittibâ‘ ve lâzımü'l-imtisâlimin mazmûn-1 münîfi üzere 'âmil olasız. Şöyle bilesiz 'alâmet-i şerife i'timâd kılasız. Tahrîren fi'l-yevmi’s-sâmin 'aşer şehri Safer sene isnâ 'aşere ve mi'eteyn ve elf.

Bi-makāmı Kostanyiniyyeti'1-mahrûse 
Sira No : : 46

Belge No : Adana Ş.S. 55, img. 77, sayfa 152, belge 16

Tarih $\quad$ : 15 CA 1212 / 5 Kasim 1797

Konu : : Adana Mütesellimi Hasan Paşazâde Ahmed Bey, Mehmed Bey ve Mustafa Bey’in uhdelerinde olan Yörügân Mukāta'ası tablosudur.

Hâlen Adana Mütesellimi Hasanpaşazâde Ahmed Bey birâderleri Mehmed Bey ve Mustafa Bey Hazretlerinin 'uhdelerinde Yörügân Mukāta'asının

\begin{tabular}{|l|c|}
\hline & Guruş \\
\hline İki yüz on bir senesi mâlından mübâşeretim hasebiyle ahz olunan 3500 guruşdur. & 3500 \\
\hline $\begin{array}{l}\text { İki yüz on iki senesine mahsûben eyâlet-i Adana'dan cebelüye me'mûriyetim ha- } \\
\text { sebiyle İçil'den bir nefer ile nefs-i Adana' dan cem ‘an }\end{array}$ & 0540 \\
\hline $\begin{array}{l}\text { Adana mukāta'atından me'mûriyetim hasebiyle boyahâneden on bir senesine } \\
\text { mahsîben bir senelik mîrî akçası üç yüz dokuz }\end{array}$ & 0309 \\
\hline İhtiyârzâde Mukāta'asından yedi yüz otuz iki guruş ahz olunmuşdur. & 0732 \\
\hline Ateş İmâmdan ahz olunan yüz guruş ahz olunmuşdur & 0100 \\
\hline $\begin{array}{l}\text { Hacı Boşnak'dan ahz olunan üç yüz doksan bir guruşdur } \\
\text { Yine mîr-i mûmâ ileyh hazretlerinin bâ-emr-i 'âlî ‘uhdesinde olan iki yüz on iki se- } \\
\text { nesi Adana cizyesi mâlından harc-1 aklâm ve peşîn ve mîrî akçası min haysü'l-mec- } \\
\text { mû' on üç bin beş yüz yetmiş iki guruşdur. Sahh }\end{array}$ & 8000 \\
\hline
\end{tabular}


Sira No $: 47$

Belge No : Adana Ş.S. 55, img. 78, sayfa 152, belge 18

Tarih $\quad$ : 15 CA 1212 / 5 Kasim 1797

Konu : : Hasanpaşazâde Ahmed Bey’den ahz olunan on bir bin iki yüz guruşa dair

Hâlen Adana Mütesellimi Hasanpaşazâde necâbetlü Ahmed Bey Hazretlerinden me'mûriyetim hasebiyle ceste ceste ahz ü kabz ettiğim mebâliği mîr mûmâ-ileyh ile birâdeleri Mehmed Bey ve Mustafa Bey 'uhdelerinde olan Yörügân Mukāta'asının iki yüz

\begin{tabular}{|l|l|}
\hline & Guruş \\
\hline On bir senesi taksîd mâlı iki bin beş yüz guruş guruş ahz olunmuşdur. & 2500 \\
\hline $\begin{array}{l}\text { Yine mîr-i mûmâ ileyhümânın mukāta'a-i mezbûrdan devletlü veliü'l-ni'am def- } \\
\text { terdâr efendimizin mâl-1 kalemiyyesi olarak ahz olunan }\end{array}$ & 1200 \\
\hline $\begin{array}{l}\text { mîr-i mûmâ ileyh Ahmed Bey Efendi'nin ber vech-i maktû' 'uhdesinde olunan iki } \\
\text { yüz on bir senesi mâl-1 cizye-i }\end{array}$ & 0000 \\
\hline Adana'dan bâkî deyn-i 'atik içün tamâmen ahz olunan yedi bin beş yüz guruşdur. & 7500 \\
\hline $\begin{array}{l}\text { Min haysü'l-mecmû' mîr-i mûmâ ileyh yedinden 'an nakdin ve bâ-poliçe ahz u } \\
\text { kabz olunan on bir bin iki yüz guruşdur. }\end{array}$ & 11200 \\
\hline
\end{tabular}


Sira No : 48

Belge No : Adana Ş.S. 55, img. 14, sayfa 26, belge 205

Tarih $\quad$ : 17 C $1212 / 7$ Aralik 1797

Konu : Adana'dan kırk katâr deve temin edilmesine dair gönderilen ferman.

Mefâhirü'l-kuzât ve'l-hükkâm ma'denü'l-fezâ'il ve'l-kelâm vilâyet-i Adana'da vâk1' kazâların kâdîları ve nâ'ibleri zîde fazluhum ve kıdvetü'l-emâcid ve'l-a‘yân Adana Mütesellimi Ahmed Bey ve zikr-i âtî şütürânın mübâya'asına me'mûr kılınan dergâh-1 mu'allâm gedüklülerinden Mahmud zîde mecdühu ve mefâhirü'l-emâsil ve'l-akrân a'yân ve zâbitân ve sâ'ir iş erleri zîde kadrühum tevkî'-i refî‘'i hümâyûn vâsıl olıcak ma'lûm ola ki:

Vidinli Pasbanoğlu Osman nâm nemek be-harâm muktezâ-yı cibiliyeti üzere i'lân-1 isyân idüb tarafından asker tertîb ve irsâli ile geçen sene Tırnovi kasabasını ve cevânibini ve bu def'a Niğbolu Kal'ası ve havâlisini küffâr gibi top ve humbara ile taht ü tarâc ve nice bî-günâh nis-

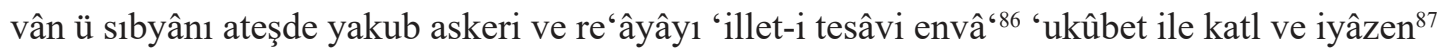
billâhi ta ‘âlâ emvâl-i müslimîni iğtinâm ve ahrâr-1 mü'minîni esir idüb ve savb-1 izâlesinin şer' ve kānûn ve 'azl ü nakl tevâfuk etmekden nâşî şimdiye değin şakiyy-i merkûmun tav'an ve kerhen mütâba'at ve icrâ-yı şekâvetinde mu'âvenet etmişken şimden sonra nâ'ib ve müstağfir olub devlet-i 'aliyyem ocaklarına dahîl düşerek ve senâ-yı harb ü darbın kezâlik tav'an girü tarafına gelenlerin cerâhim-i sâbıka ve lâhıkaları ma'fuvv olmak üzere fakat şakî-i merkûmun ve kendüsü ile şekâvetde 1srâr ile muhârebeye tasaddî idenlerin ber mantûk-1 fetvâ-y1 şerîf cezâ-yı sezâları tertîb olunmak içün mahsûs asker ve ser-asker ta'yîn olunmak üzere olub ancak ser-asker ma‘iyyetlerinde istihdâm içün emr-i şütûrânın lüzûmu derkâr ve Istabl-1 'âmireme tâbi' orta ve kışlaklarında mevcûd olan şütürâna kıllet gelüb hîn-i iktizâda mevcûd bulunmak içün beher hâl bir mikdâr şütürân mübâya'asına ihtiyâc hiss eylediği zâhir ve bedîdâr olduğuna binâ'en vilâyet-i Adana'da vâk1' kazâlarda bulunan mahallerden kırk katar deve mübâya'ası tertîb ve sînin-i sâbıkda mübâya'a olunduğu üzere beher katarı mükemmel ve pusat-1 sâ'iresiyle üçer yüz guruşdan kırk katâr devenin on iki bin guruş bahâsıyla mübâya'a olunan mahallerden Asıtâne-i sa'âdetime gelince beher katârına ber vech-i mu'tâd olan dokuzar guruşdan yediyüz altmış guruş nafaka bahâlarıyla cem'an on iki bin yedi yüz altmış guruşun nısfı hîn-i tekemmülünde virilmek şartıyla nısf-1 âheri olan altı bin üç yüz seksen guruş 'an nakdin ta 'yîn olunan mübâşire i'tâ ve irsâl olunmağla sen ki mütesellim-i mûmâ ileyhsin mârrü'z-zikr kırk katar şütürânı yüke el verir güçlü ve kuvvetli ve tüvânâ be-gâyet güzîde ve tüylü olmak ve bir mehârı boz ve koca olmamak şartıyla vilâyet-i Adana'da vâk1‘ kazâlarda bulunan kurâlardan ma'rifetin ve ma'rifet-i şer' ve mübâşir-i mûmâ ileyh ma'rifeti ve cümle ittifâkıyla serî'an ve 'âcilen mübâya'a ve tekmîl ve kefillü ve beyânlu mu'temed sarbânlar tedârük ve tevdî‘ ve tesellüm idüb anlar dahi esnâ-yı râhda yem ve yiyeceklerine

86 Metinde ع şeklinde yazılmışıtır.

87 Metinde عياز yيازن șeklinde yazılmıştır. 
bakub gereği gibi görüb ve göze(te)rek kal'1ndan sıyânet eylemen ve eğer bir mehârı zâyi“ ve telef ve hilâf-1 'âmel-mânde ve koca ve lâgar olur ise sarbânbaşıdan ve sâ'ir iktizâ idenlerden tazmîn eylemeği te' dîb ve gûşmal olacaklarını tefehhüm iderek mübâşir eline terfîkan Der-'aliyyeme irsâl ve Asıtâne-i 'aliyyeme tesellüme bezl ü sa'y-1 makderet ve bulunmayan kazâlara hisse tarh ve tahmîl ile fukarâyı rencîdeden müba'âdet eylemen fermânım olmağın hâssaten işbu emr-i celîlü’l-kadrım 1sdâr ( ) ile irsâl olunmuşdur. İmdi vusûlünde mevkûfâtdan muhrec mümzâ ve sûret-i defterde mastûr olduğu üzere kırk katâr şütürân güçlü ve yüke el verir genç ve tüvânâ gâyet güzîde ve tüylü olmak ve bir mehârı boz ve koca ve sâkat olmamak şartıyla vilâyet-i Adana'da bulunan mahallerden mükemmel hâvud ve pusat-1 sâ'iresiyle beher katârına üçer yüz guruşdan nısfları hîn-i tekmîlinde i'tâ olunmak üzere nısf bahâları 'an nakdin ashâbına edâ ü teslîm olunarak ma'rifetin ve ma'rifet-i şer' ve mübâşir-i mûmâ ileyh ma'rifeti ve cümle ittifâkıyla serî'an mübâya'a ve tekmîl ve sârbânlar dahi tedârük ve ta'yîn birle bir sâ'at akdem Der-'aliyyeme irsâl ve Istabl-i 'aliyyem tarafina tesellüm etdirilmesi husûsuna mezîd-i dikkat ve sa'y-1 gayret eyleyesin. Şöyleki işbu mîr-i şütûrân lüzûmu mikdâr tertîb olunmasından olunduğundan sinîn-i sâbıkada olduğu misüllü bedele kat' 1 ve yâhûd ve bir mehârın tenzîline istid‘âsıyla tahrîrât irsâl ve bî-hûde evkāta dikkat olunmak lâzım gelür ise ta'tîl-i maslahata sebeb olanların icrâ-yı te'dîblerinde iğmâz olun(maya)cağı iktizâ idenlere ifâde ve tefehhüm birle hemân ol mikdâr katâr şütürânı beş on gün zarfinda mübâya'a ve tekmîl ve sârbâlarıyla mübâşir-i mûmâ ileyhe teslîmen Der-sa'âdetime irsâle dikkat eyleyesin ve sen ki mübâşir-i (mûmâ) ileyhsin ${ }^{88}$ muktezâ-yı me'mûriyetin üzere o tarafa lede'l-vusûl mütesellim-i mûmâ ileyhin ma'rifeti ve ma'rifet-i şer' ve mübâşeretin ma'rifetiyle mübâya'ası tertîb ve fermân olan kırk katâr şütürân yüke el verir güçlü ve kuvvetlü genç ve tüvâna tüylü olmak şartıyla mükemmel hâvud ve pusat-1 sâ'iresiyle sinîn-i sâbıkada mübâya'a olduğu üzere beher katârına üçer yüz guruşdan îcâb iden bahâlarının nısfi hîn-i tekmîlinde virilmek üzere nısfları ashâblarına edâ ü teslîm ve yerlerinden akdem mübâya'a ve ba'de’t-tekmîl ve esnâ-y1 râhda Üsküdar'a gelince beher katârına on dokuzar guruşdan nafaka bahâları yediyle virilen akçadan virilerek bir sâ'at mukaddem Der-'aliyyeme tesyîr ve Istabl-1 'âmirem tarafina teslîm eylemeğe ihtimâm birle ashâb-1 şütürânın bahâlarının makbûzlarını müş 'ir hüccet-i şer'iyye ahz ve getürüb mevkûfâtına kayd itdirmeğe dikkat ve mâ'eze Allâhu ta'âlâ ashâb-1 şütürân1mın mîrîden verilecek deve bahâlarından ve gerek esnâ-yı râhda nafaka bahâlarından bir akça ve bir habbesini ketm ve kat' birle fukarâ-yı ra'iyyete cevr ü ezâ eylemekden esnâ-yı râhda gözedilmeyüb telef ve helâklarından ziyâde hâzer ü mübâ'aded eyleyesin ve sen ki kuzât ve nüvvâb ve a'yân ve zâbitân-1 mûmâ ileyhümâ ve sâ'irleri sizler dahi bu husûsa ihtimâm ü dikkat ve hilâf-1 emr-i 'alîşânım ednâ mertebe vaz' ü hareketden be-gâyet tevakkî eylemeniz (bâbında) fermân-1 'âlîşânım sâdır olmuşdur. Buyurdum ki:

Hükm-i şerîfimle ( ) vardıkda bu bâbda sâdır olan vech-i meşrûh üzere şeref-yâfte-i sudûr olan işbu emr-i şerîf-i celîlü ‘ş-şân-1 vâcibü'l-ittibâ‘ ve lâzımü'l-imtisâlimin mazmûn-1 münîfi üzere 'âmil olub hilâfiyla vaz' (ü) hareketden be-gâyet tehâşî ü mücânebet eyleyesiz. Şöyle 
bilesiz 'alâmet-i şerîfe i'timâd kılasız. Tahrîren fi'l-yevmi's-sâbi 'aşer min şehri Cemâziyye'l-ahir sene isnâ ve 'aşere ve mi' eteyn ve elf.

Bi-makāmı Kostantiyyeti'l-mahrûse

Bundan akdem şütürân-1 mezkûrun isti'câli içün iki kıt'a emr-i şerîf zuhûr eyledikden sonra bu def'a dahi Ramazânü'l-mübârek'in sekizinci günü târîhiyle bir kıt'a ve on üçüncü târîhiyle bir k1t'a dahi cem'an dört kit'a isti'câl emri zuhûr eylediği bu mahalle şerh verildiği kayd şod. 
Sira No : : 49

Belge No : Adana Ş.S. 55, img. 16, sayfa 31, belge 200

Tarih : : 4 N 1212 / 20 Şubat 1798

Konu : Adana ve Sis Livası Mukāta'asının Adana sakinlerinden Hüseyin'e iltizam olunduğuna ve vergilerin toplanmasına yardım edilmesine dair ferman.

Kıdvetü'l-kuzât ve'l-hükkâm me‘âdinü'l-fazlı ve'l-kelâm Mevlânâ Adana kâdısı zîde fazluhu ve kıdvetü’l-emâcid ve'l-a‘yân Adana Mütesellimi Ahmed zîde mecdühu tevkî‘-i refî‘-i hümâyûn vâsıl olıcak ma'lûm ola ki:

Hâlen Dîvân-1 hümâyûn (çavuşu?) iftihârü'l-emâcid ve'l-ekârim câmi'-i mehâmid ve'l-mekârim Osman dâme mecdühunun takdîm eylediği takrîr mefhûmunda zamân-1 zabtı Mart ibtidâsindan olub ber vech-i mâlikâne 'uhdesinde olan resm-i ispenc-i eyâlet-i Adana ve livâ-i Sis Mukāta'asını işbu bin iki yüz on iki senesi Mart ibtidâsından Şubat'1 gâyetine değin bir sene-i kâmile idâre eylemek üzere Dergâh-1 mu'allâm gedüklülerinden Adana sâkinlerinden Hüseyin dâme mecdühuya der-'uhde ve iltizâm olduğu ve mukāta'a-i mezbûrun senevî mâlından havâle olunan mahallere edâ ve tesellümü rüsûmât-1 mîriyyesinin yerlü yerinden ve îcâb idenden cem‘ ü tahsîl ve kabzına ve (مرختلنه) irsâline menût ve münhasır olduğuna binâ'en mukāta'a-i mezbûru sene-i mezkûre Mart ibtidâsından bir seneye değin mûmâ ileyh zîde mecdühuya verilen iltizâm temessükü mûcibince zabt u rabt itdirilüb vâk1 ‘ olan rusûmâtın kanûn-1 kadîm ve sinîn-1 sâbıkda ola geldiği üzere yerlü yerinden ve îcâb (ü) iktizâ idenlerinden bir pâresi gerüye kalmamak üzere 'alâ eyyi hâlin tahâssülüne siz ki kâdî ve mütesellim-i mûmâ ileyhümâsız tarafınızdan min külli'l-vücûh mu'âvenet ve mâl-1 mîriyye kesr ü noksândan sıyânet eylemek bâbında emr-i şerîfim sudûrunu inhâ ve iltimâs eylemekden nâşî kuyûda mürâca'ât olundukda mukāta'a-i mezbûr senevî ma'lûmu'l-mikdâr mâl ile siz refî'-i mûmâ ileyhin ber vech-i mâlikâne 'uhdesinde olduğu ve bu makûle mukāta'a'ât-1 mîriyyeyi der'uhde ve iltizâm iden mültezimine mâlikâne ve mukāta'aların verdikleri iltizâm temessükü mûcebince bir sene-i kâmile zabt u rabt ve hâs1lât-1 rusûmâtın kānûn-1 kadîm ve ola geldiği üzere mezbûrînden ve îcâb (ü) iktizâ edenlerden ahz u kabz ve cem‘ ü tahsîl etdirilmek verilen emr-i şerîfim şurûtundan idiği başmuhâsebeden derkenâr olunmağla inhâsı ve derkenârı mûcebince 'amel ü hareket eylemeniz fermânım olmağın hâssaten işbu emr-i 'âlîşânım ile 1sdâr ve îsâl olunmuşdur. İmdi vusûlünde mukāta'a-1 mezbûru sene-i mezkûre Martı ibtidâsından Şubat'1 gâyetine varınca mûmâ ileyh Hüseyin zîde mecdühuya sâbıkı ve ola geldiği üzere bir sene-i kâmile zabt-1 rabtı ve hâsılât ve rusûmâtın ahz u kabz cem' ü tahsîlinde min külli'l-vücûh mu'âvenet ve mâl-1 mîriyye kesr ü noksândan sıyânet ve mugâyir-i emr-i 'âlîşânım müdâhale ideri olur ise men ' ü def' ine ihtimâm ü dikkat eylemeniz bâbında fermân-1 'âlîşânım sâdır olmuşdur. Buyurdum ki: Hükm-i şerîfimle vardıkda bu bâbda vech-i meşrûh üzere şeref-yâfte-i sudûr olan işbu emr-i şerîf-i celîlü'ş-şân-1 vâcibü'l-ittibâ' ve lâzımü'l-imtisâlimin mazmûn-1 itâ'at-makrûnu üzere 'âmil olub hilâfiyla kimesneye müdâhale ve ta'arruz etdirmeyesiz. Şöyle bilesiz 'alâmet-i şerîfe i'timâd kılasız. Tahrîren fi'l-yevmi’r-râbi' şehri Ramazan sene isnâ 'aşere ve mi'eteyn ve elf.

Bi-makāmı Kostantiniyyeti'l-mahrûse. 
Sira No : 50

Belge No : Adana Ş.S. 55, img. 18, sayfa 35, belge 195

Tarih : Evahir L 1212 (29 Mart- 7 Nisan 1798)

Konu : Sayda Valisi Cezzar Ahmed Paşa'nın tatarının Adana yakınlarında eşkıya tarafından öldürmesi üzerine Adana'nın emniyetinin sağlanmasına dair ferman.

Kıdvetü'l-emâcid ve'l-a'yân bu def'a diğer sâdır olan emr-i şerîfimle Adana Mütesellimi nasb ü ta'yîn olan Paşabeyzâde Ahmed Bey zîde mecdühu tevkî‘-i refî́-i hümâyûn vâsıl olıcak ma'lûm ola ki:

Sen ki mütesellim-i mûmâ ileyhsin bundan akdem şeref-yâfte-i sudûr olan emr-i şerîfimle beş yüz nefer süvârî asker ile medîne-i Adana Beylerbeyisi ve Rumili cânibinde Pasbanoğlu üzerine me'mûr olub bu def'a bâ-rütbe-i vâlâ-yı vezâretle kadri terfí' ve a'lâ kılınan düstûr-1 mükerrem müşîr-i mufahham nizâmu'l-'âlem vezîrim Yusuf Paşa edâme Allâhu ta‘âlâ iclâlehu mansıbına erişüb ta'allum ve istihdâm eylediği hıdemâtın te'diyesine ikdâm eylemek üzere me'mûr ve ta'yîn kılınmış idik. Ancak bir müddetden berü Adana eyâleti dâhilinde kâ'in 'âşâyir eşkıyâsı ferceyâb olub ahâli-i memleket ve fukarâ-yı ra'iyyete hilâf-1 şer'-i şerîf ve mugâyir-i rızâ-yı hümâyûnum itmedikleri zulm u ta'addi ve cevr ü ezâ kalmadığından mâ'adâ ebnâ-yı sebîl ve mârr (ü) âbirîne tasallut eyledikleri ve merhametli fukarâ-penâh hâlen Sayda Vâlîsi düstûr-1 mükerrem müşîr-i mufahham nizâmu'l-'âlem vezîrim El-hâcc Cezzâr Ahmed Paşa edâme Allâhu ta â̂lâ iclâlehu tarafından Der-'aliyyeme meb 'ûs tatarı Kurtkulağı menzilhânesinden sürücüsüyle üç re's bârgire süvâr ve Ilıcak Beli nâm mahalle vusûlünde eşkıyâ-yı merkûmdan ol tarafda tecemmü‘ ve tahassun eden hınzırât tatar-1 merkûmun üzerine bi'l-hücûm ve sürücüsüyle bî-sebeb katl ve üzerlerinde olan emvâl ü eşyâları gasb eyledikleri ve böyle kalur ise Adana tarîkinden ebnâ-yı sebîl ve ulakların inkıtâ'1yla ol havâli câddesi külliyen müstevlî olıcağı bi’l-ihbâr ve vâsıl-1 sâmi‘a-i şehriyârânem olub eşkıyâ-yı merkûmun havâlî-i merkûmda bu derece ferceyâb olarak ahâlî ve ebnâ-i sebîle îsâl-i zulm ü hasâr ve katl-i nüfûsu ibtidâr itmeleri ancak senin iğmâz ve rehâvetinden neş'et eylediğinde iştibâh olmamağla vusûl-1 emr-i şerîfimde derhâl tatar-1 mezkûrun kātilleri her kimler ise taharrî ve tecessüs olunarak bi-eyyi hâlin ele getürüb gasb u gârât eyledikleri emvâl ü eşyâyı tamâmen zâhire ihrâc ve muhkem habs ve kefîllerini isim ve resimleriyle Der-aliyyeme tahrîr ü inhâya müsâra'at ve ba'dehu ne vechile emr-i şerîfim sâdır olur ise mûcib ve muktezâsı ile 'amel ü hareket ve fî̀-mâ-ba'd eyâlet-i merkûme dâhilinde bu makûle hasârât ..hâli zuhûr ile ahâlî-i memleket ve fukarâ-1 ra'iyyet ve ebnâ-1 sebîle ser-i mû îsâl ( )m ve hasârat vukû'a gelmemek üzere taht-1 râbıta ve nizâm-1 re‘âyâya dâmen dermeyân-1 gayret ve hilâf-1 rıâ-yı hümâyûnum hareketden be-gâyet tehâşî ü mücânebet eylemen fermânım olmağın sâlimen ve ilhâken ve husûs-1 mezkûr uhdene ihâle olunduğu ihtimâmen ve hâssaten işbu emr-i şerîfim 1sdâr ( ) ile irsâl olunmuşdur. İmdi eyâlet-i mezkûre dâhilinde olan haşerâtın def' ü ref'i hasren ve hasren senden matlûb-1 kat'1-y1 dâverânem olduğu ve ba dd-ez-în ol taraflardan ferd-i vâhidin mâl 
ve cânına ednâ zarar ü gezend isâbet etmemek ve bu bâbda infâz-1 emr ü irâde-i şâhânemde mikdâr-1 zerre ihmâl ü rehâvet vukû'a gelmek ihtimâli olur ise bir vechile cevâba kādir olmayub mazhar-1 gazab-1 hüsrevânem olacağın bî-iştibâh idüğü ma'lûmun oldukda ber vech-i muharrer vusûl-i emr-i şerîfimde tatar-1 merkûmun kātilleri her kimler ise sicilleri ile getürüb ve gârât eyledikleri mâl ü eşyâ her ne ise tamâmen ve kâmilen zâhire ihrâc ve .... mezkûreye cesâret idenleri muhkem habisde îkâ ve isim ve resimleri takrîr Der-'aliyyeme tahrîr ü inhâya mübâderet ve ba'dehu ne vechile emr-i şerîfim sâdır olur ise mûcib ve muktezâsı ile 'amel ü harekete ihtimâm fî-mâ-ba'd eyâlet-i merkûme dâhilinde bu makûle hasâret zuhûruyla ahâli-i memleket ve fukarâ-yı ra'iyyet ve ebnâ-yı sebîle zulm ü hasâret vukû'a gelmemek içün râbıta ve nizâma idhâl ile esbâb-1 ahâli ve te'mîn-i turuk ü mesâlik husûslarına mezîd-i dikkat ü ikdâm ve hilâfından be-gâyet tehâşî ü mücânebet eyleyesiz.

Şöyle ki bu vesîle ile vedî‘a-i cenâb-1 Rabb-1 'izzet olan fukarâ-y1 ra'iyyet ve sükkân-1 memlekete hilâf-1 şer'-i şerîf ve mugâyir-i rıâ zulm ü ta'addîye cesâret ve bî-cürm ve bî-günâh makûlesine azm-1 töhmet ü kabâhat ile bu maddeyi celb-i mâla vesîle ve âlet etmekden tevakkî ve mübâ'adet ve keyfiyetini ber vech-i tafsîl derbâr-1 şevket-karâr-1 mülûkâneme tahrîr (ve) işâret eylemen bâbında fermân-1 'âlisşânım sâdır olmuşdur. Buyurdum ki: ( ) vusûl buldukda bu bâbda vech-i meşrûh üzere şeref-yâfte-i sudûr olan fermân-1 vâcibü'l-ittibâ' ve lâz1mü'l-imtisâlimin mazmûn-1 itâ‘at-makrûnuyla 'amel ü hareket ve hilâfından be-gâyet tehâşî ü mücânebet eyleyesiz. Şöyle bilesiz 'alâmet-i şerîfe i'timâd kılasız. Tahrîren fî evâhiri Şehri Şevvâli'l-mükerrem sene isnâ 'aşere ve mi'eteyn ve elf.

Bi-makāmı Kostantiyyeti'l-mahrûse 
Sira No : 51

Belge No : Adana Ş.S. 55, img. 19, sayfa 36, belge 193

Tarih : : 5 ZA $1212 / 21$ Nisan 1798

Konu : Adana cizyesinin Ahmed Bey’e 13.000 guruşa tefviz edildiğine ve 1891,5 guruş olan mevacibinin İstanbul'a gönderilmesine dair ferman.

Kıdvetü'l-kuzât ve'l-hükkâm ma‘denü'l-fazlı Mevlânâ Adana kâdîsı zîde fazluhu ve kıdvetü’l-emâcid ve'l-a‘yân Adana Mütesellimi Ahmed Bey zîde mecdühu ve kıdvetü'l-emâsil ve'l-akrân bu husûsa mübâşir ta'yîn olunan defterdâr-1 şıkk-1 evvelim etbâ'indan İsmail zîde kadrühu tevkî'-i refî'-i hümâyûn vâsıl olıcak ma'lûm ola ki:

Adana cizyesinin gayr-1 ez ma'âş fi'l-asl yirmi beş bin üç yüz yetmiş sekiz guruş mâlı olub ancak el-hâletü hâzihi hâsılâtı mâl-1 mukayyedi mikdârına bâliğ olmayacağı tashîh olunmağla bi-mennihi ta 'âlâ bundan böyle tanzîmine dikkat birle asl-1 mâl-1 mukayyedine iblâğ olunmak şartıyla sen ki mütesellim-i mûmâ ileyhsin gayr-1 ez ocaklık menzil bin iki yüz on iki senesine mahsûben zikr olunan Adana cizyesi iltimâsına bina'en on ${ }^{89}$ üç bin guruşa maktû'an 'uhdene ihâle ve tefvîz olunmuşidi. Şimdi bin iki yüz on üç senesine mahsûben dahi cizye-i mezkûre sâbıkı üzere hazîne-i 'âmirem defterlerinde 'uhdene kayd ü berât ve evrâk boğcası mübâşir-i merkûm ma'rifetiyle tarafına irsâl olunmağın vusûlünde boğca-i mezkûrı ahz ve gurre-i Muharremü'l-harâm' da ma'rifet-i şer'le mührüni fekk ü küşâd ve kalem-i mezbûr ve tevâbi'inde sâkin ve mevcûd yerlü ve yabanc1 ve mürûr ü 'ubûr iden ehl-i zimmetin esnâf-1 selâse üzere mâl ve mülklerine göre 'ale'r-ru'us evrâklarını tevzî' ve iktizâ eden mâl-ı cizyelerinin cânib-i mîrîçün cibâyet ve tahsîline şürû‘ ve mübâşeret birle divân-1 müşeyyedü’l-erkân-1 mülûkânemde ihrâcı musammem olan kapum kulları mevâcibine müretteb bin beş yüz guruş peşîn akçasıyla kaleminden muhrec mümzâ sûret-i defterde terkîm olunan üç yüz doksan bir buçuk guruş harc-1 aklâm ve avâ'idât-1 sâ'ireyi mübâşir-i merkûma teslîmen Der-'aliyyeme irsâl ü tesyîr eylemen fermânım olmağın işbu emr-i 'âlîşânım ısdâr ve mübâşir-i merkûm ile irsâl olunmuşdur. İmdi vusûlünde bâlada beyân olunduğu üzere cizye-i mezkûr bin iki yüz on üç senesine mahsûben gayr-1 ez ocaklık menzil sâbıkı üzere on üç bin guruşa maktû'an 'uhdene kayd ü berât ve evrâk boğçası tarafina irsâl olunmuş olduğu ma'lûmun oldukda sene-i merkûmeye mahsûben kalem-i mezbûr ve tevâbi' inde sâkin ve mevcûd ve mürûr u 'ubûr iden ehl-i zimmetin esnâf-1 selâse üzere hâl ve istihkāklarına göre 'ale'r-ru'us evrâkları tevzî' ve iktizâ eden mâl-1 cizyelerinin cibâyet ve tahsîline şürû' ve mübâşeret birle mevâcibe müretteb bin beş yüz guruş peşîn akçasıyla üç yüz doksan bir buçuk guruş harc-1 aklâm ve 'avâ'idât-1 sâ'ireyi mübâşir-i merkûmâ teslîmen Der-'aliyyeme irsâl ü tesyîre müsâra'at eyleyesin. Şöyle ki mevâcib-i mezkûrun beher hâl ihrâcı bu makûle mürettebâtın vaktiyle gelüb teslîm-i hazîne-i 'âmirem olunmasına menût olmağla hemân meblağ-1 mezbûru tedârük ve hazîne-i 'âmirem ve mahallerine edâ ve teslîme mübâderet ve sen ki mübâşir-i merkûmsun me’mûr-1 îsâli olduğun 
berât ve evrâk boğcasını mashûben bi's-selâme mütesellim-i mûmâ ileyhe teslîm ve mevâcibe müretteb sâlifü'z-zikr bin beş yüz guruş peşîn akçasıyla süver-i defterde terkîm olunan harc-1 aklâmı mütesellim-i mûmâ ileyhden ahz ve ihrâc-1 mevâcibden mukaddem getürüb hazîne-i 'âmirem ve mahallerîne tamâmen eda ve teslîme dikkat ve esnâ-yı râhda ve mahallinde bilâ mûcib meks ü ikāmetden mücânebet ve sen ki kâdî-1 mûmâ ileyhsin sen dahi mûcib-i emr-i şerîfimle 'amel ü hareket eylemeniz bâbında fermân-1 'âlîşânım sâdır olmuşdur. Buyurdum ki:

Hükm-i şerîfimle ( vardikda bu bâbda vech-i meşrûh üzere şeref-yâfte-i sudûr olan işbu emr-i şerîf-i celîlü'ş-şân-1 vâcibü'l-ittibâ‘ ve lâzımü'l-imtisâlimin mazmûn-1 itâ‘at-makrûnuyla 'âmil olasız. Şöyle bilesiz 'alâmet-i şerîfe i'timâd kılasız. Tahrîren fí'l-yevmi'l-hâmis şehri Zil'-ka'de sene isnâ 'aşere ve mi'eteyn ve elf.

Bi-makāmı Kostantiniyyeti'l-mahrûse 
Sira No : : 52

Belge No : Adana Ş.S. 55, img. 50 sayfa 99, belge 104

Tarih $\quad$ : 19 ZA $1213 / 24$ Nisan 1798

Konu : Ahmed Bey’in mütesellim olarak atandığına dair buyuruldu.

Şerî‘at-şi‘âr Adana kâdısı fazîletlü efendi zîde fazluhu ve kıdvetü'l-emâcid ve'l-ayân Paşabeyzâde izzetlü Ahmed Bey zîde mecdühu ve mefâhirü'l-emâsil ve'l-akrân a'yân ve zâbitân ve sâ'ir iş erleri zîde kadrühum ba'de's-selâm inhâ olunur ki: İşbu evân-1 meymenet-iştimâlde avâtıf-1 'aliyye-i mülûkâne ve 'avârıf-1 behiyye-i seniyye-i hüsrevâneden şeref-bahşâ-yı sudûr olan hatt-1 hümâyûn-1 şevket-makrûn mûcibince işbu bin iki on üç senesi Zi'l-ka'de-i şerîfesinin yirmi altıncı gününde eyâlet-i Adana 'uhdemize tevcîh ve inâyet ü ihsân-1 hümâyûn buyurulub bir k1t'a fermân-1 celîlü'ş-şân şeref-rîz-i vürûd etmekle imdi eyâlet-i mezkûreye bir mu'tedil ve muktedir ve kâr-güzâr kimesnenin mütesellim nasb ü ta'yîni lâzım ve lâbüd olmağla mûmâ ileyh Ahmed Bey eyâlet-i mezkûreye mütesellim nasb ü ta'yîn olunduğu siz ki muhâtabîn-i mûmâ ileyhimsiz ma'lûmunuz oldukda mütesellim-i mûmâ ileyhin her hâlde re'y ü tedbîr üzere kemâl-i ittifâk ve ittihâz üzere hareket ve hıfz ü himâyet ve fukarâ-i ra 'iyyet husûslarına ve zabt ü rabt-1 memleket ahvâlinde merâsim-i ittihâd ü ittifâka kemâl-i ri'âyet eylemenizi muhtevî ve sen ki mütesellim-i mûmâ ileyhsin eyâlet-i merkûmeye mütesellim nasb ü ta'yîn olunduğun beyânıyla işbu buyuruldu divân-1 Adana'dan tahrîr ve 1sdâr ve kıdvetü'l-emâsil ve'l-akrân tatar ağamız El-hâcc Mehmed Ağa zîde kadrühu ile irsâl olunmuşdur. İnşâ'e Allâhu Ta'âlâ vusûlünde gerekdir ki vech-i meşrûh üzere sen ki mütesellim-i mûmâ ileyhsin eyâlet-i merkûmede mütesellim olub zabt ü rabt-1 memleket ve himâyet ve sıyânet-i fukarâ ve re‘âyâ ve vülât-1 'izâm tarafına 'â'id ve râci' olan cüz'î ve küllî hâsılâtını ahz u kabz birle min külli’l-vücûh umûr-1 mütesellimliği idâre husûslarına mezîd-i ihtimâm ü dikkat ve kemâl-i sa‘y-1 gayret ve senden me'mûl ve müntazarımız olduğu vechile her bir umûr ve husûsda dâmen der-meyân-1 gayret ü hamiyyet olunub ber mûcib-i buyuruldu 'amel ü hareket ve hilâfından tehâşî ve tevakkî ü mübâ'adet ve hazer ü mücânebet eyleyesin deyü. Fî 19 ZA sene 1213 
Sira No : 53

Belge No : Adana Ş.S. 55, img. 24, sayfa 46, belge 178

Tarih : : 1 S $1213 / 15$ Temmuz 1798

Konu : : Ahmed Bey’in Adana serdarı tayin edildiğine dair Yeniçeri ağası mektubu.

Şerî‘ at-şi‘âr Adana Kâdîsı Efendi zîde fazluhu ba'de’s-selâm inhâ olunur ki:

Taht-1 hükûmetinizde serdâr olan ref‘ olunub yerine uslûb-1 sâbık üzere kıdvetü’l-emâsil ve'lakrân Hasanpaşazâde Ahmed Bey zîde kadrühu serdâr nasb ü ta'yîn olunmağın işbu mektûb tahrîr ve irsâl olunmuşdur. İnşâ’e Allâhu ta ‘âlâ vusûlünde gerekdir ki merkûmu kazâ-i mezkûrun serdârlığı umûrunda kıyâm ve öteden berü ola geldiği vechile zabt ü rabtı husûsunda i'ânet ve ihtimâm eyleyesiz ve sen ki serdâr-1 merkûmsun kazâ-i mezkûrun serdârlı̆̆ı sana tefvîz olunmağla gerekdir ki kâ'ide-i kadîm ve kānûn üzere zabt ü rabt-1 neferât ve def' ü ref'-i haşerâtıyla tanzîm-i bilâd ve irâhe-i hâl-1 ibâda bezl-i iktidâr eyleyesin ve kazâ-i mezkûrda mukîm ve müsâfir yeniçerileri ve cebeci ve topcu ve top arabacısı ve gılmân-1 'acemi ve kuloğulları bi'l-cümle seni üzerlerine serdâr ve zâbit bilüb sözünden taşra ve re'yinden hâric vaz' ü hareketde bulunmayub dâ'imâ itâ'at ü inkıyâd üzere olalar ve sen dahi cümle umûrunu ahkâm-1 şer'-i şerîf ve kānûn-1 kadîm ve emr-i münîfe tatbîk ve tavâ'if-i merkûmûndan bilâ vâris-i ma'rûf fevt olanların metrûkâtlarının ma'rifet-i şer'le zabt ve Sûk-i sultânîde fürûht ve hâsıl olan nükûdun cânib-i beytü'l-mâl içün defter müfredâtıyla ocak tarafına göndermeğe mübâderet ve beher hâl sükkân-1 vilâyetin emn ü râhatlarına bâ'is hıdemât-1 müstahsene-i mebrûre vücûda getürmeğe mucidd ü sâ‘î olub mûcib-i mektûbla 'âmil olası. Tahrîren gurre-i Saferü'l-hayr sene selâse 'aşer ve mi'eteyn ve elf.

El-fakîr Eyüb Ağa-yı Yeniçeriyân-1 Dergâh-1 ‘âlî 
Sira No : 54

Belge No : Adana Ş.S. 48. img. 68, sayfa 133, belge 213

Tarih : : 24 RA 1217 / 05 Eylül 1798

Konu : Ahmed Bey'in mâlikâne uhdesinde olan Küçük Kend ve sâ'ir dört 'aded mukāta'âtın taksit akçası olan ma'a harc-1 vezne 2873 kuruş 54 akçanın İstanbul'a gönderilmesine dair.

İftihârü'l-emâcid ve'l-ekârim câmi 'u'l-mehâmid ve'l-mekârim el-muhtassu bi-mezîdi 'inâyeti'l-meliki'd-dâ‘im Dergâh-1 Mu'allâm Kapucıbaşılarından Adana Mütesellimi Ahmed Bey dâme mecdühu ve mefâhirü'l-kuzât ve'l-hükkâm me‘âdini'l-fezâ‘il ve'l-kelâm zikr-i âtî mukāta'aların bulundukları mahallerin kâdîları ve nâ'ibleri zîde fazluhum ve mefâhirü'l-emâsil ve’l-akrân bu husûsa mübâşir ta'yîn olunan defterdâr-1 şıkk-1 evvelim çukadârlarından Mehmed ve a'yân ve zâbıtân ve iş erleri zîde kadrühum tevkî‘'i refî‘-i hümâyûn vâsıl olıcak ma'lûm ola ki:

Kaleminden ihrâc ve derûn-1 emr-i şerîfime mevzû'an irsâl olunan mümzâ sûret-i defter nâtık olduğu üzere bin iki yüz on yedi senesine mahsûben Adana eyâletinde vâk1' ba'zı kesânın ber vech-i mâlikâne 'uhdelerinde olan mezra'a-i Küçük Kend ve sâ'ir dört 'aded mukāta'âtın taksit akçası olan ma'a harc-1 vezne iki bin sekiz yüz yetmiş üç guruş elli dört akça bi-mennihi ta ‘âla işbu sene-i mübâreke Şa‘bânın'da divân-1 müşeyyedü’l-erkâni'l-mülükânemde kapum kullarına ihrâc ve tevzî‘i musammem olan kısteyn mevâcibine tertîb ve tahsîs kılınmakdan nâşî meblağ-1 mezbûrun bir gün evvel tahsî1 ${ }^{90}$ ve hazîne-i 'amireye (irsâl) husûsuna irâde-i seniyyem ta'alluk itmekle sen ki mütesellim-i mûmâ ileyhsin ma'rifetin ve ma 'rifet-i şer' ve mübâşir-i merkûm ma'rifeti ve cümle ittifâkıyla ber mûceb-i sûret-i defter meblağ-1 mezbûru mukāta'at-1 mezbûr mutasarrıflarından ve kendüleri mevcûd olmadıkları hâlde mültezimlerinden ve anlar dahi mevcûd değil ise mukāta'atı hasılâtından ve îcâb ü iktizâ edenlerden tamâmen tahsîl ve mübâş̧ir-i merkûma teslîmen Der-sa'âdetim'e irsâl ve hazîne-i 'amireme teslîme bezl ü sa'y-1 makderet eylemen fermânım olmağın işbu emr-i 'alîşânım 1sdâr ve mübâşir-i merkûm ile irsâl olunmuşdur. Vusûlunde bâlâda tahrîr ü beyân ve sûret-i defterde tasrîh ü ayân kılındığu üzere meblağ-1 mezbûru yerlü yerinden tamâmen tahsîl ve mübâşir-i merkûma teslîmen ve serî'an ve 'acilen ve mevâcib-i mezkûr ihrâcından mukaddem hazîne-i 'amireme teslîmi matlûb-1 şahânem idüği ma'lûmun oldukda vürûd-1 emr-i şerîfimde meblağ-1 mezbûru ma'rifetin ve ma'rifet-i şer' ve cümle ittifâkıyla 'alâ eyyi hâlin tamâmen ve kâmilen yerlü yerinden tahsîl ve mübâşir-i merkûma teslîmen Der-sa'âdetim’e irsâl ve hazîne-i 'amireme teslîme müsâra'at eyleyesin ve sen ki mübâşir-i merkûmsun muktezâ-yı me'mûriyetin üzere meblağ-1 mezbûr iki bin sekiz yüz yetmiş üç guruş elli dört akçayı ma 'rifet-i şer' ve mübâşeretin ${ }^{91}$ ve cümle ittifâkıyla bi-eyyi hâlin tamâmen tahsîl ve ahz ve istishâb ve bir gün evvel

90 Kelime iki defa yazılmıştır.

91 Kelime (مبارشتكلة) şeklinde yazılmıştır. 
getürüb hazîne-i 'âmireme teslîme mezîd-i sa'y ü gayret ve hilâf-1 rzâ tûl müddet meks ü tevakkufdan gâyetü'l-gâye mücânebet eyleyesin ve siz ki kuzât ve nüvvâb ve a'yân ve zâbıtân-1 mûmâ ileyhim ve sâ'irlerisiz sizler dahi mûcib-i emr-i şerîfimle 'amel ü hareket ve meblağ-1 mezbûrun tamâmen tahsîli husûsuna bi' '-ittifâk ihtimâm ü dikkat eylemeniz bâbında fermân-1 'âlîşânım sâdır olmuşdur. Buyurdum ki:

Hükm-i şeriffimle vardıkda bu bâbda vech-i meşrûh üzere şeref-yâfte-i sudûr olan işbu emr-i şerîf-i celîlü'ş-şân-1 vâcibü'l-ittibâ‘ ve lâzımü'l-imtisâlimin mazmûn-1 itâ'at-makrûnuyla 'âmil olub hilâfından tevakkî ü mübâ'adet eyleyesiz. Şöyle bilesiz 'alâmet-i şerîfe i'timâd k1lasız. Tahrîren fi'l-yevmi'r-râbi “ 'işrîn şehri Rebî'i' i'l-evvel sene seb'a 'aşer ve mi' eteyn ve elf.

Bi-makāmı Kostantiniyyeti'l- mahrûse 
Sira no $\quad: 55$

Belge no : BOA, C. DH 25/1237

Tarih : :9 C 1213 / 23 Ekim 1798

Konu : : Adana halkının Ahmed Bey’den sonra Hacı Ali Beyzâde Mustafa Bey’in mütesellimliğinden şikâyet etmelerine ve Mustafa Bey yerine Ahmed Bey gibi güçlü bir mütesellim tayin olunması taleplerine dair

Adana tarafindan vârid olan evrâkın hülâsasıdır. Fî 18 CA sene (1)213.

Sâbıkan Adana Mütesellimi Ahmed Bey fukarâ ve zu'afânın asâyiş-i emn ü râhatlarına ikdâm-1 tâmm iderek Adana havâlîsinde vâk1 ' aşâ'ir ve kabâ'ilin ebnâ-i sebîle vâk1' olan ta 'addîlerinin indifâ'‘yla turuk ve enhânın tanzîf ve tathîri ve me'mûr olduğu emvâl-i mîriyyenin tahsîli emrine sa'y ü ikdâmı cihetiyle Adana ahâlîsi mûmâ ileyhden hoşnûd ve şâkir iken bu def'a Adana'ya mütesellim nasb olunan Hâcı Ali Beyzâde Mustafa Bey hadîsü's-sinn olub zabt ü rabt-1 memlekete kudreti olmadığı nümâyân ve Adana Karataş İskelesinin mahall-i akrebi olan etrâfı cevelângâh-1 eşkıyâ olduğuna mebnî beher-hâl mütesellim-i sâbık misüllü cesûr bir mütesellim nasb buyurulması lâzımeden idüği zâhir ve ayân olduğu beyânıyla fukarânın hâllerine merhameten Adana mütesellimliği kemâ-fi's-sâbık mûmâ ileyh Ahmed Bey'e ihâle birle fukarâ ve zu'afânın du'âvât-1 hayriyyeleri isticlâbına himmet ve inâyet buyurulmasın Adana ve Tarsus kâdîları birer kit'a i'lâmlarında ve ahâlîsi birer kıt'a mahzarlarında ve Adana müftîsi lâhık ve sâbık iştirâken bir kıt'a arzıhâllerinde ve müftî-i sâbık iki kıt'a kā'imesinde tahrîr iderler.

Sahh. Mûcebince merkûm Ahmed Bey'e Adana mütesellimliğinin ihâlesiçün iktizâsına göre verilmesi buyuruldu. Fî 9 C sene 213. 
Sira No : : 56

Belge No : Adana Ş.S. 48, img. 67, sayfa 130, belge 208

Tarih : : 19 RA 1213 / 29 Ekim 1798

Konu : Adana Mütesellimi Ahmed Bey’den Adet-i Ağnam-1 Dündarlı ve Tevabii Mukāta‘ası'nın 1214 senesi malından olmak üzere iki bin beş yüz guruşun tahsil edildiğine dair.

Bâ'is-i tastîr-i tahvîl oldur ki:

Hâlen Adana Mütesellimi devletlü ser-bevvâbîn-i Dergâh-1 'alî Hasanpaşazâde Ahmed Bey Hazretlerinin 'uhdesinde olan 'âdet-1 ağnâm-1 Dündarlu ve Tevâbi'i Mukāta'ası'nın iki yüz on dört senesi mâlından olmak üzere Dergâh-1 'alî Kapucıbaş1larından Osman Bey’e kalyon masârıfiçün iki kıt'a rûznâmçe-i hümâyûn temessükü mûciblerince havâle olunan altı bin üç yüz kırk üç buçuk guruşun tahsîline me'mûr olduğumuz hasebiyle bu def'a bin iki yüz elli guruş ve yine mukāta'a-i merkûmun iki yüz on beş senesi mâlından olmak üzere on dokuz kit'a rûznâmçe-i hümâyûn temessükâtları mûciblerince mevâcibe havâle olunan yedi bin yüz elli beş buçuk guruşun dahi tahsîline me'mûr olduğumuz hasebiyle bu def'a bin iki yüz elli guruş ile cem'an iki bin beş yüz guruşu mîr-i mûmâ ileyh Ahmed Bey Efendi Hazretleri yedinden tamâmen ve kâmilen ahz u kabz eylediğimizi müş ‘ir li-ecli’s-sened işbu tahvîl tahrîr ve yed-i mûmâ ileyhe i'tâ olundu. Vakt-i hâcetde ibrâz ve ihticâc oluna ve's-selâm.

Fî 19 Rebî'i’l-ulâ sene 1213

El-fakîr Ahmed çukadâr-1 sadr-1 a'zamî hâlen. 
Sira No : 57

Belge No : Adana Ş.S. 55, img. 29, sayfa 56-57, belge 158-159

Tarih $\quad$ : 29 CA 1213 / 08 Kasim 1798

Konu : : Adana'dan yüz elli mehâr deve yollanmasina dair ferman.

Mefâhirü'l-kuzât ve'l-hükkâm me‘âdinü’l-fezâ‘il ve'l-kelâm Adana sancağında vâk1' kazâların kâdîları ve nâ’ibleri zîde fazluhum ve kıdvetü'l-emâcid ve'l-a'yân Adana Mütesellimi Ahmed Bey ve bu husûsa mahsûs mübâşir ta 'yîn olunan sadr-1 a'zamım çukadârlarından kıdvetü'l-emâsil ve'l-akrân İbrahim zîde mecdühumâ (k1dvet)ü'l-emâsil ve'l akrân vücûh-1 memleket ve iş erleri zîde kadrühum tevkî́'-i refî́'-i hümâyûn vâsıl olıcak ma'lûm ola ki:

Fransalu'nın mugâyir-i sulh ü salâh hareketi ve bağteten Kahire-i Mısır üzerine hücûm ve istilâsı hasebiyle taraf-1 şer'den verilen fetvâ-yı şerîf mûcebince berren ve bahren tedârükât-1 kaviyye ile mütevekkilen 'ale'(llah) mekâyid-i düşman-1 dîne kıyâm olunmak cümle ehl-i İslâm'a farz-1 'ayn olduğundan hâlen Şam Vâlîsi ve Misır cânibi Ser-'askeri düstûr-1 mükerrem müşîr-i mufahham nizâmu'l-‘âlem vezîrim El-hâcc İbrahim Paşa edâme Allâhu ta âla iclâlehu dahi ma'iyyetine müretteb 'asker-i mansûre ile Misır'ın istihlâsına me'mûr kılınub ancak ser-'asker ordusunda zahîre ve mühimmât nakli ve sâ'ir hıdemât-1 lâzımede istihdâm olunmak içün sefer-i (sâbıkda) olduğu misüllü Anadolu'da vâk1' semt ve münâsib olan mahallerden bir mikdâr mekkârî şütürânı tertîb ve 'alâ cenâhi'l-isti'câl ser-'asker-i müşarun ileyh ma'iyyetine irsâl ü tesyîli husûsuna irâde-i kātı'a-i mülû(kânem) ta'alluk itmekle yüke girdikleri günden hıdmetde olduklarınca ber mu'tâd lâzım gelen ücretleri ser-(asker)-i müşârün ileyh ma'iyyetine me'mûr sârbânbaşı yedinden virilmek şartıyla mevkûfâtdan ihrâc ve derûn-1 emr-i şerîfime mevzû'an irsâl olunan memhûr ve mümzâ sûret-i defter mûcebince Adana sancağından (tertîb) olunan yüz elli mehâr mekkârî develeri derhâl tahammülüne göre livâ-i mezbûrede vâk1' kaza$\operatorname{lar}($ dan) ve serî'an ve 'âcilen yerlü yerinden ihrâc ve mübâşir-i mûmâ ileyh ma'iyyetiyle Şam-1 Şerîf'e sevk ü tesyâr eylemen fermânım olmağın hâsseten işbu emr-i celîlü'l-kadrım 1sdâr ve irsâl olunmuşdur. İmdi vusûlünde siz ki (kuzât) ve nüvvâb ve mütesellim-i mûmâ ileyhim ve sâ'irlerisiz bu husûsda cümleniz gönül birliği idüb ol mikdâr mekkârî develerinin mecmû‘u yüke el virir ve haml-1 sakîle mütehammil gâyet güzîde ve tüvânâ ve hâvut ve çuval ve (urgân) ve sâ'ir alât ve pusatları mükemmel ve cedîd olmak şartıyla derhâl tevzî‘ ve yola ihrâc ve ('alâ ) cenâhi'l-isti'câl ser-'asker-i müşârün ileyh ma'iyyetine irsâl olunması sizden matlûb-1 mülûkânem(olmağın) ma'âze Allâhu ta 'âlâ bu emr-i ehemmde her kimin tarafindan ednâ mertebe tekâsül ve te'hîr misüllü hareket ve yâhûd ve tenzîl dâ'iyyesiyle bî-hûde tahrîrât irsâline cesâret olunmak lâzım gelür ise bir dürlü (sem') ü i 'tibâr olunmayacağından kat'-1 nazar te'hîr ü terâhiye sebeb ve 'illet olanların te'dibleri (emrinde) dakîka fevt olunmayacağını tefehhüm birle matlûb olan ol mikdâr mekkârî develerini der-'akab tevzî‘ ve mükemmel tâkımları ve kefîllü sârbânlarıyla 'alâ cenâhi'l-isti'câl Şâm-1 Şerîf'e irsâl ve ser-'asker-i müşârün ileyh ma'iyyetine sevk ü isâle ziyâde sür'at ü şitâb eyleyesiz. Şöyle ki: ser-'asker-i müşârün ileyhin 
me'mûr(iyeti) hıdemât-1 dîniyyeden olmağla bu bâbda tereddüd ve muhâlefet dîn ü devlete hiyanet makûlesi olduğu(ndan) âna göre hareket ve hilâfindan hazer ü mücânebet eyleyesiz ve sen ki mübâşir-i mûmâ ileyhsin ( ) serî‘an mahalline varub Adana sancağından tertîb olunan sâlifü’z-zikr yüz elli mehâr şütürândan bir re'si gerüye kalmayarak ne vechile ve tarîk ile olur ise olsun üç beş gün zarfında tevzî‘ ve ber vech-i muharrer mükemmel tâkımı ve sârbânlarıyla ihrâc ve (irsâl) ve 'alâ cenâhi'l-isti 'câl ser- 'asker-i müşârün ileyh ma ‘iyyetine îsâl ve teslîm ve tamâmen vusûl-1 müşârün ileyhden tahrîrât ahz ve ol vehcle Der-sa ‘âdetim'e 'avdet ve 'iyâzen bi'llahi ta'âlâ ihmâl ve müsâmaha ile ta 'tîl-i maslahatdan sen dahi tehâşî ü mücânebet eylemen bâbında fermân-1 'âlîşânım sâdır olmuşdur. Buyurdum ki hükm şerîfimle ( ) vardıkda bu bâbda vech-i meşrûh üzere şerefyâfte-i sudûr iden işbu emr-i şerîf-i celîlü'ş-şân-1 vâcibü'l-ittibâ‘ ve lâzımü'l-imtisâlimin mazmûn-1 münîfi birle 'âmil olub hilâfından hazer ü mücânebet eyleyesiz. Şöyle bilesiz 'alâmet-i şerîfe i'timâd kılasız. Tahrîren fî’l-yevmi’t-tâsi' 'aşer şehri Cemâziye'l-evvel sene selâse 'aşer ve mi'eteyn ve elf.

Bi-makāmı Kostantiniyyeti'l-mahrûsa

Husûs-1 mezkûr içün iki def'a isti ‘câli hâvî emr-i 'âlî vurûd eylediği kayd şod.

(Pençe) 
Sira No : : 58

Belge No : Adana Ş.S. 56, img. 32, sayfa 74, belge 1

Tarih $\quad$ : 2 CA $1213 / 12$ Ekim 1798

Konu : Adana Valisi Ataullah Paşa'nın alacağı olan 10.000 kuruş için Adana Mütesellimi Ahmed Bey ve aşiretin birbirlerine kefil olduklarına dair.

Bâ'is-i hurûf-1 temessük oldur ki:

İşbu bin iki yüz on senesi mâh-1 Ramazanü'l-mübârekin on sekizinci gününde bundan akdem Adana Vâlîsi müteveffâ Ataullah Paşa'nın zimemâtında 'aşîretimiz ahâlîlerinde olan on bin guruş alacak meblağı bâ-emr-i 'âlî cânib-i mîriden zabt ve mutâlebe olunmağla beş bin guruşu on bir gün mürûrunda ve beş bin guruşu dahi doksan bir gün mürûrunda va 'de ile hâlen Adana Mütesellimi Hasanpaşazâde sa âdetlü Ahmed Bey hazretlerine tamâmen ve kâmilen edâ ve teslîm eylemek üzere birbirimize kefîl-i bi’l-mâl ve kefîl-i bi’n-nefs olmak şartıyla kendi tarafımızdan asâleten ve 'aşiretimiz ahâlîleri tarafından vekâleten deynine ta'ahhüd eylediğimizi müş ir işbu deyn temessükü tahrîr ve mütesellim-i mîr-i mûmâ ileyh yedine i tâ olundu. Gerekdir ki meblağ-1 mezbûr on bin guruş deynimizi tamâmen ve kâmilen edâ ve teslîm eylediğimizde işbu temessükümüz şakk oluna ve's-selâm

El-fakîr Ahmed Ömerzâde

El-fakîr Halil Ömeroğlu

El-fakîr Es-seyyid Hizır Kerim

El-fakîr Es-seyyid Mehmed Abdülkadiroğlu

El-fakîr Es-seyyid Mîr Mustafa

El-fakîr Mîr Es-seyyid Ahmed Menemencizâde

Meblağ-1 mezbûr tamâmihâ Cabbarzâde tarafına edâ ve teslîm olunmuşdur ve's-selâm.

Fî 2 CA sene 213 (12 Ekim 1798) 
Sira No : 59

Belge No : Adana Ş.S. 55, img. 50-51 sayfa 99-100, belge 103

Tarih : :1213-1798

Konu : Adana menzili için 8.000 guruş imdadiyenin tahsil edilerek menzilciye teslim edilmesine dair.

Mefâhirü'l-kuzât ve'l-hükkâm ma'denü'l-fezâ'il ve'l-kelâm vilâyet-i Adana ve Sis ve Tarsus kazâlarının kâdîları efendiler zîde fazluhum ve kıdvetü'l-emâcid ve'l-a'yân Adana Mütesellimi ( ) zîde mecdühu ve mefâhirü'l-emâsil ve'l-akrân zikr-i âtî husûsuna mübâş̧ir ta'yîn olunan (hazîne-i) hâssam hasekilerinden Ahmed Haseki ve a'yân ve zâbitân ve iş erleri zîde kadrühum tevkî‘'-i refî‘-i hümâyûn vâsıl olıcak ma'lûm ola ki:

Memâlik-i mahrûsemde vâk1' menâzilin 'ale'd-devâm hüsn-i nizâm üzere i'mâl ve idâreleri akdem umûr-1 mehâmm-1 devlet-i 'aliyyemden olub bu husûs bi'z-zât sadr-1 a'zam-1 sütûde- şiyem ve vekîl-i mutlak-1 kaviyyü'l-himem düstûr-1 ekrem müşîr-i efham nizâmu'l-'âlem nâzım-1 menâzım-1 ümem² El-hâcc Yusuf Ziya Paşa edâme Allâhu Ta‘âlâ iclâlehu zâ‘ifu bi’tte'bîd ikbâluhu ve iktidârehunun ordu-yı hümâyûnumla Şam-1 şerîf cânibine 'azîmeti muhakkak olduğuna mebnî Şam-1 şerîf caddesinde olan menziller evkât-1 sâ'ireden ziyâde müte'azzım olmak lâzım iken ekser menâzilin nizâmı olmadığg eğerçi bundan akdem Anadolu'nun üç koluna nizâmı hâvî evâmir-i şerîfem 1sdâr ve mübâşirler tisyâr olunmuş ise dahi sefer-i hümâyûnum gâ'ilesi ber taraf oluncaya dek menzillerin nizâmı az vakitde bozulmayacak vechile esfâr-1 sâbıkaya kıyâs ile tanzîm olunması husûsuna irâde-i seniyyem ta'alluk etmekle hazîne-i 'âmirem defterleri tetebbu' olundukda kırk üç târîhinde İran seferi zuhûr eyledikde tarîk-i câddede olan menâzilin hüsn-i nizâm üzere idaresiçün kurb ve civâr olan kazâlardan imdâdiye ta'yîn ve bir an akdem yerlü yerinden tahsîl ve menzilcilere teslîm birle emr-i nizâmı eyâlet ve sancak mutasarrıflarına ve voyvoda ve mütesellimlere ve hükkâm ve a'yân ve zâbitâna ihâle birle tanzîm olunmuş olub ancak bu makûle menâzilin re's-i senesi ibtidâ-1 rûz-1 Hızır olmakdan nâşî işbu bin iki yüz on üç senesi rûz-1 Hızırından i'tibâr ile gerek bu'dları olan kazâ ve nevâhiden her bir menzile mikdâr-1 (kifâye)ve dahi imdâdiyye tertîb olunmağla esfâr-1 sâbıkada olu geldiği gibi vechile ${ }^{93}$ Adana menziliçün sekiz bin guruş imdâdiye tertîb ve ta'yîn olunmağla mevkûfâtdan muhrec sûret-i defter mûcebince meblağ-1 mezbûru sen ki mütesellim-i mûmâ ileyhsin ma'rifet ve ma'rifet-i şer' ve mübâşir-i merkûm ma'rifetiyle vilâyet-i Adana ve Sis ve Tarsus kazâları ahâlilerinden tamâmen tahsîl ve cümle ittifâkıyla kavî kefîli ahz olunarak nasb ü ta'yîn olunacak menzilciye edâ ve teslîm ve menzilci dahi kadr-1 vefâ tüvân bârgîr ve müstevfî̀ zehâ'ir ve sürücüler ve levâzım-1 sâ'irelerini derhâl tedârük ve tekmîl ve fî-mâ-ba'd gâ'ilesi çekilmemek umûr-1 mühimme-i müsta'cele ile me'mûr-1 mübâşirîn ve ulakların bir neferi bir an ve bir dakîka bî-hûde meks ü tevkîf itdirilmemek vechile hüsn-i nizâ-

92 Ümem kelimesi “ومم" şeklinde yazılmıştır.

93 Gibi kelimesi fazladan yazılmıştır.

Belgeler, Cilt: 37/Say1: 41; 39-210 
ma ifrâğa ve tanzîme ve ale'd-devâm hüsn-i nizâm üzere ru'yet ve idâreleri husûsuna hükkâm ve zâbıtân nezâret ve ihtilâl-i nizâmını mûcib hâletden hazer ü mücânebet olunmak fermânım olmağın bâ-takrîr işbu emr-i celîlü’l-kadrım 1sdâr ve mübâşir-i merkûm ile irsâl olunmuşdur. İmdi vusûlünde ber vech-i muharrer gâ'ile-i sefer-i hümâyûn bertaraf oluncaya değin tarîk-i Şam-1 şerîfede vâk1‘ menâzilin evkât-1 sâ'irden ziyâde râbita ve nizâmları ve umûr-1 mühimme-i müsta 'cele ile me'mûr-1 mübâşirîn ve ulaklar ve hezâ'in-i mîriyyenin bir kadem akdem zehâb ü iyâbları akdem umûrdan olmakdan nâşî Adana menziliçün vilâyet-i Adana ve Sis ve Tarsus kazâlar(1n)dan müretteb sekiz bin guruş imdâdiye ma'rifetin ve ma'rifet-i şer'ile ve mübâşir-i merkûm ma'rifetiyle ve cümle ittifâkıyla serî‘an tahsîl ve menzilci-i mezkûr(a) edâ ve teslîm olunarak mürûr ü 'ubûr edenlere vâfi tüvânâ bârgîr ve müstevfî̀ zehâyir ve sürücüler ve luzûm-1 sâ'irin tedârük ve tekmîl ve fî-mâ-ba'd gâ'ilesi çekilmeyecek vechile nizâm-1 müstahseneye ifrâğ ve tanzîm ve 'ale'd-devâm hüsn-i nizâm üzere i'mâl ve idâresi husûsuna hükkâm ve zâbıtân dahi ihtimâm ü dikkat ve ma'ezen Allâhu Ta'âlâ emr-i 'âlîşânımın hilâfı hareket ve imdâdiyye-i mürettebenin edâsında ta'allul ve muhâlefet ve bî-hûde tahrîrât irsâliyle umûr-1 mühimme-i müsta'celenin bir an ta'tîl ve te'hîrine sebeb ve 'illet olunmak lâzım gelür ise hükkâm ve a'yân-1 kazânın irâd olunacak 'özr ü 'illetleri makbûl olmayub te' dîbât-1 lâyıkaları icrâ olunacağ1 gûş-1 hûşlarına ilkâ ederek menzil-i mezkûru bir gün evvel nizâm-1 müstahseneye ifrâğ ve tanzîm ve sûret-i nizâmı hazîne-i 'âmirem defterine sebt ü kayd içün icâleten Der-'aliyyeme tahrîr ü inhâya müsâra'at eyleyesiz ve sen ki mübâşir-i mûmâ ileyhsin senden sadâkat ve istikâmet me'mûl olmakdan nâşî akrânın meyânında bi'l-intihâb hâssaten bu husûsa me'mûr k1lındığın ma'lûmun oldukda dâmen-i gayreti meyân-1 hamiyyete bend idüb müretteb olan sâlifü'z-zikr imdâdiyye(y)i 'alâ eyyi hâlin tahsîl ve menzilciye teslîm ile umûr-1 menzil-i mezkûru ber vefk-i matlûb serî‘an tanzîm(e) i'tinâ ${ }^{94}$ ü dikkat ve hilâfindan hazer ü mücânebet eyleyesiz. Şöyle bilesiz 'alâmet-i şerîfe ${ }^{95}$. 
Sira No $: 60$

Belge No : Adana Ş.S. 55, img. 42 sayfa 82, belge 119

Tarih : :1223-1798

Konu : Adana ve çevresinden 2.000 aded deve çuvalının toplanılarak ordu-yı hümayuna gönderilmesine dair emr-i şerif.

Adana çuvâl emr sûretidir

Mefâhirü'l-kuzât ve'l-hükkâm me‘âdinü’l-fezâ'il ve'l-kelâm Adana sancağında vâk1' kazâların kâdîları ve nâ'ibleri zîde fazluhum ve kıdvetü'l-emâsil ve'l-akrân a'yân ve Mütesellim Ahmed Bey zîde mecdühu ve bundan akdem mübâşir ta'yîn olunan el-yevm ol cânibde olan ( ) tevkî'-i refî'-i hümâyûn vâsıl olıcak ma'lûm ola ki:

Bi-‘avni'l-1lâhi Ta'âlâ ordu-yı hümâyûnumdan tahaşşüd edecek asâkirin ta'yinâtlarıçün mecma'-1 zehâyir olan İskenderun İskelesi'nde cem‘ ve iddihâr olunacak peksimâd ve dakîk hasbe'l-iktizâ Şam-1 şerîfe ve mahall-i sâ'ire nakl olunmak üzere beher hâl külliyetlü deve çuvâllarına muhtâc olmakdan nâşî beher adedi ellişer paradan îcâb eden iki bin beş yüz guruş bahâsı hîn-i teslîminde ordu-yı hümâyûnum hazînesinden verilmek şartıyla Adana sancağı ve havâlisinden iki bin 'aded deve çuvâlı tertîb ve sen ki mütesellim-i mûmâ ileyhsin ma'rifetinle fiyât-1 mezkûre ile bir gün evvel serî'an ve 'âcilen tedârük ve mübâşire teslîmen Şam-1 şerîfe nakl ü tesyîr eylemek bâbında bundan akdemce emr-i şerîfim 1sdâr ve mübâşir-i merkûm ile irsâl olunmuşidi. El-hâletü hâzihi ordu-yı hümâyûn Üsküdar'dan Haydar Paşa sahrâsında hareket ve sahrâ-yı mezbûrdan dahi bi'l-yümn ve'l-ikbâl mahall-i maksûda 'azîmet üzere olduğundan zikr olunan çuvâlları bir iki gün zarfında mübâya'a ve tedârük ve mübâşir-i merkûma teslîmen Şam-1 şerîfe nakl ve teslîm ve tesyîr eylemen fermânım olmağın te'kîd ve isti 'câli hâvî işbu emr-i 'âlîşânım 1sdâr ve sadr-1 a'zam tatarlarından Osman ile irsâl olunmuşdur. İmdi vusûlünde zikr olunan çuvâlların îcâb eden bahası hîn-i nakl ve teslîminde ordu-yı hümâyûn hazînesinden verilmek şartıyla livâ-i mezkûr ve havâlisinden ma'rifetin ve ma'rifet-i şer'ile ve mübâşir-i merkûm ma'rifeti (ile) bir an akdem ve bir sâ'at mukaddem mübâya'a ve tedârük ve mübâşir-i merkûma teslîme mübâderet eyleyesin. Şöyle ki ve husûs-1 sâ’ire mukayyes olmayub beher hâl zehâyir-i mürettebenin nakli işbu çuvâlların vurûduna mütevakkıf olduğundan her ne vechile ve tarîk ile olur ise olsun birkaç gün zarfında yerlü yerinden tamâmen tedârük ve serî'an ve 'âcilen Şam-1 şerîfe irsâle kemâl-i sa'y ü gayret eyleyesin ve sen ki mübâşir ve mütesellim-i mûmâ ileyh ma'rifeti ve ma'rifet-i şer'le ve ma'rifetinle livâ-i mezkûr ve havâlisinden mezkûrü'l-mikdâr çuvâlı mübâya'a ve tedârük ve istishâb ve bir gün evvel ordu-y1 hümâyûnuma erişdirmeğe mezîd-i sa'y ü gayret ve hilâf-1 emr-i şerîfim imrâr-1 vakitden tehâşî ü mücânebet eyleyesin ve siz ki kuzât ve nüvvâb-1 mûmâ ileyhimsiz siz dahi mûcib-i emr-i şerîfimle 'amel ü hareket eylemeniz bâbında fermân-1 'âlîşânım sâdır olmuşdur. Buyurdum ki hükm-i şerîfimle vardıkda vech-i meşrûh üzere şeref-yâfte-i sudûr eden işbu emr-i şerîf-i celîlü'ş-şân-1 vâcibü'l-ittibâ‘ ve lâzımü'l-imtisâlimin mazmûn-1 münîfi birle 'amel ü hareket eyleyesiz. Şöyle bilesiz (alâmet-i şerîfe i'timâd kılasız.) 


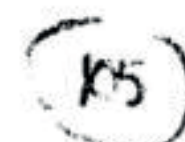

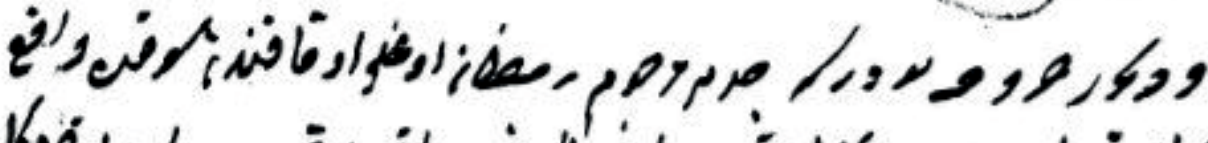

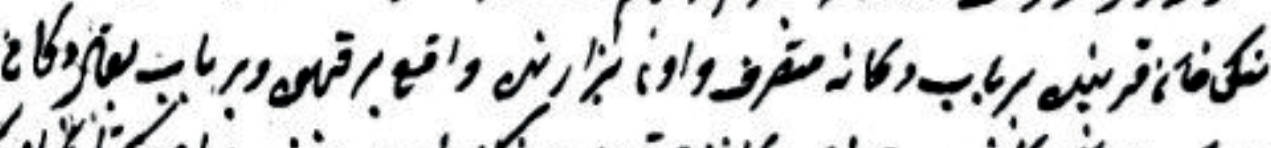

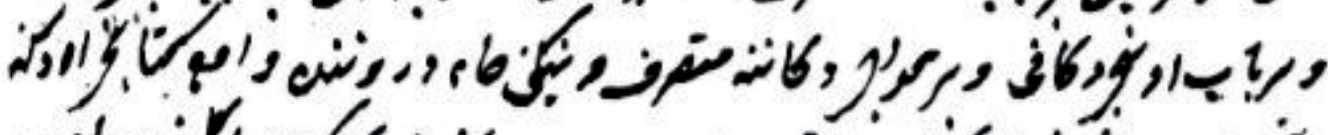

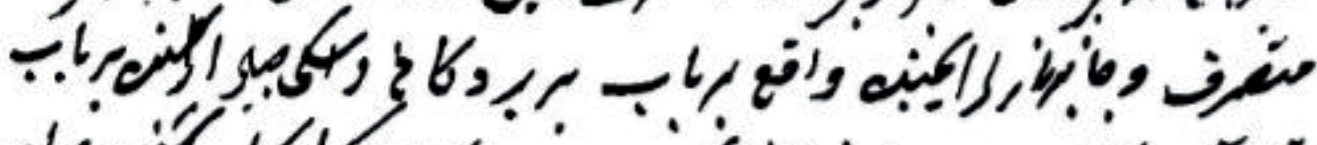

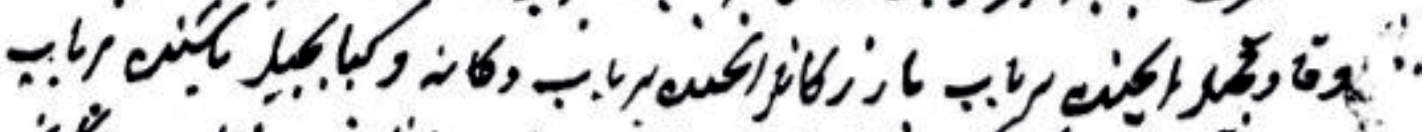
') צ' (4) وضمن

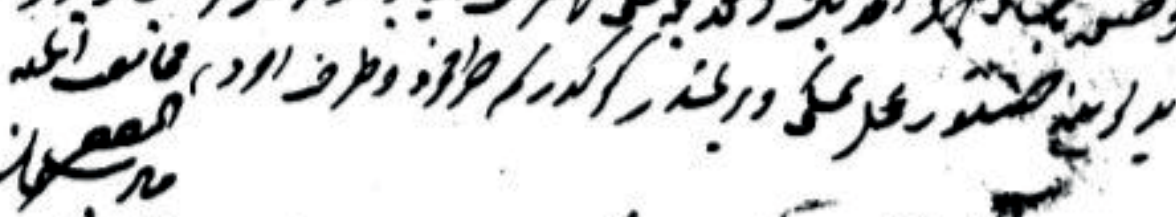

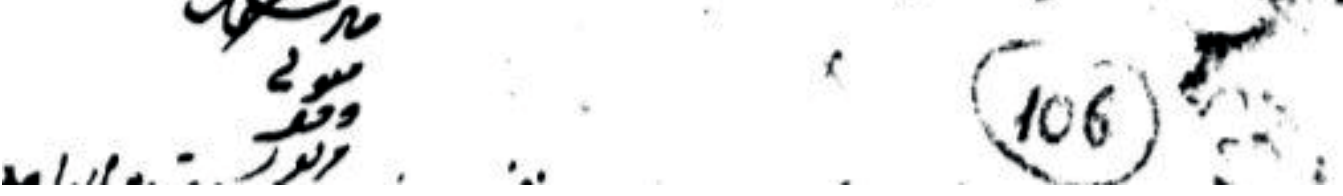

1: Adana Ş.S. 44, img. 57, belge 105 


\section{6}

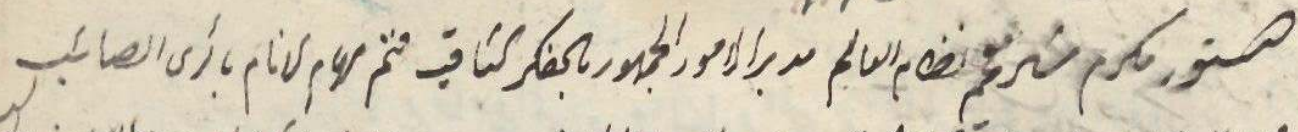

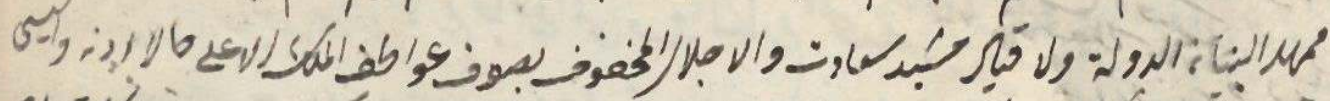

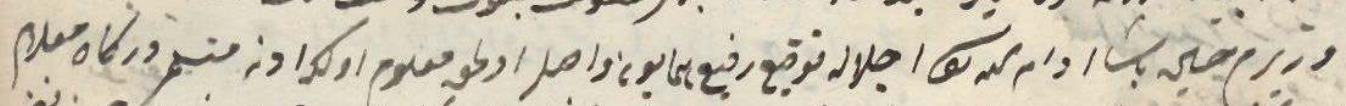

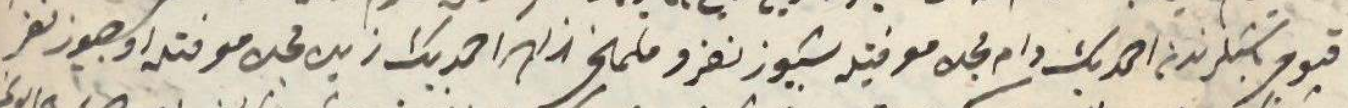

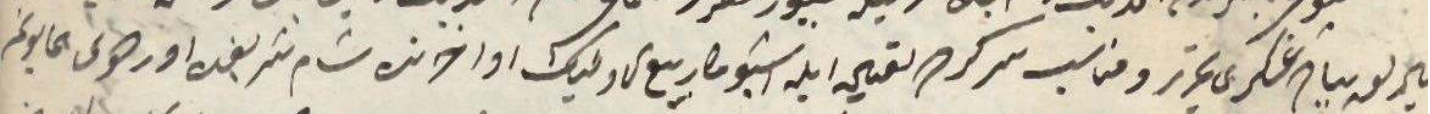

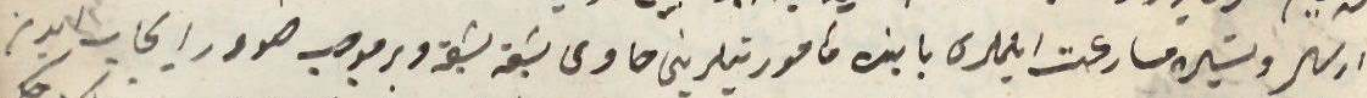

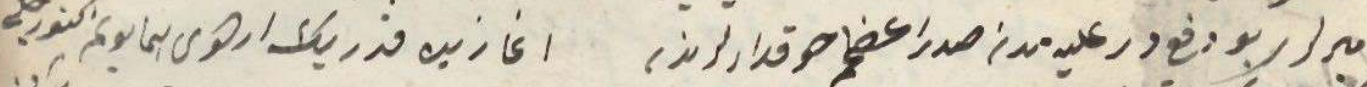

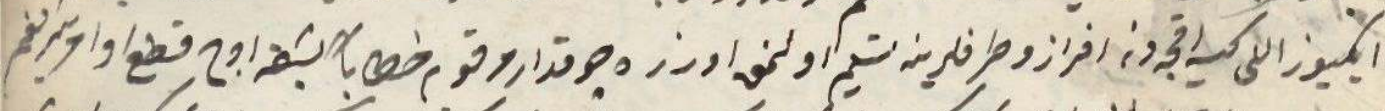

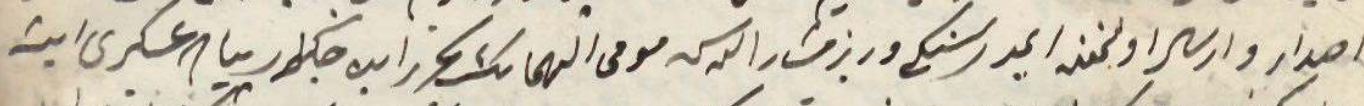

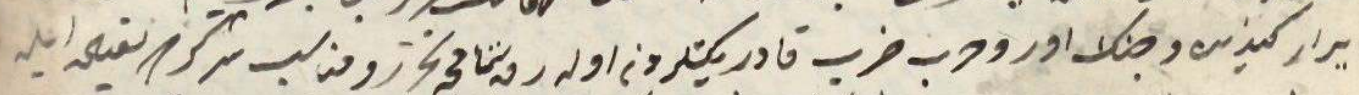

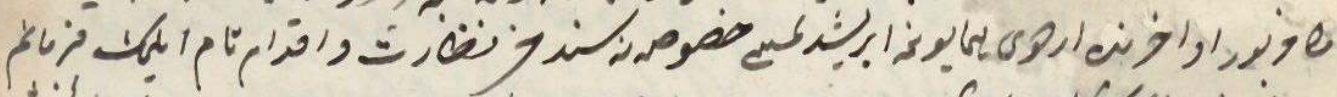

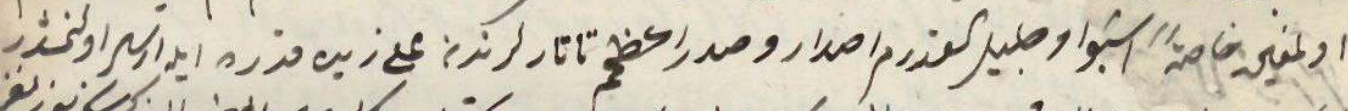

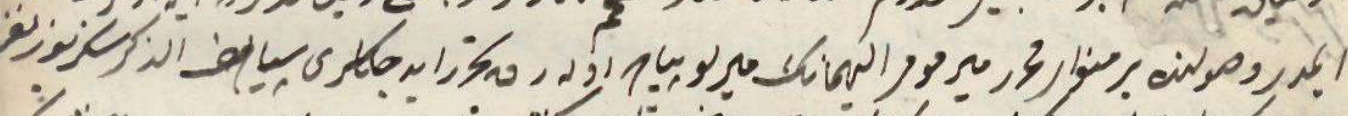
, "

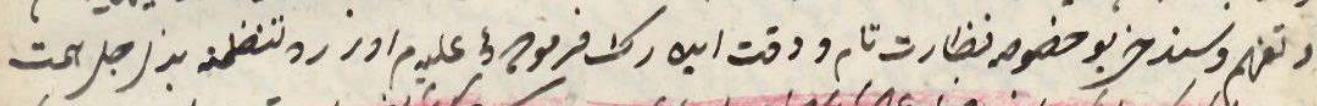

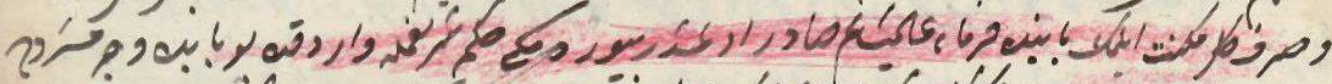

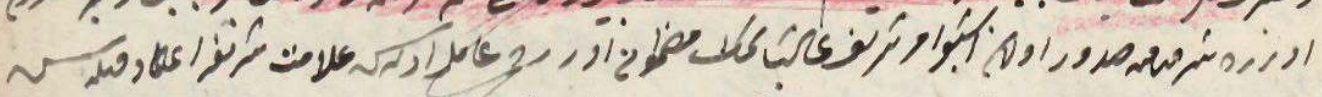

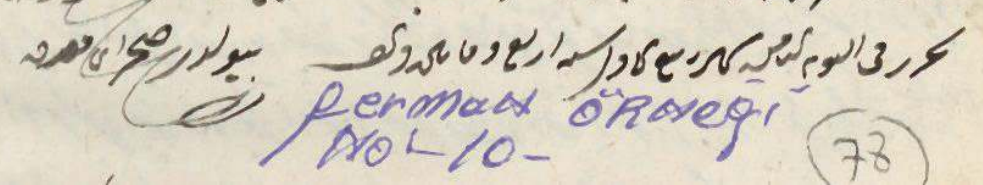

2: Adana Ş.S. 55 , img. 59 , sayfa 116 , belge 79 


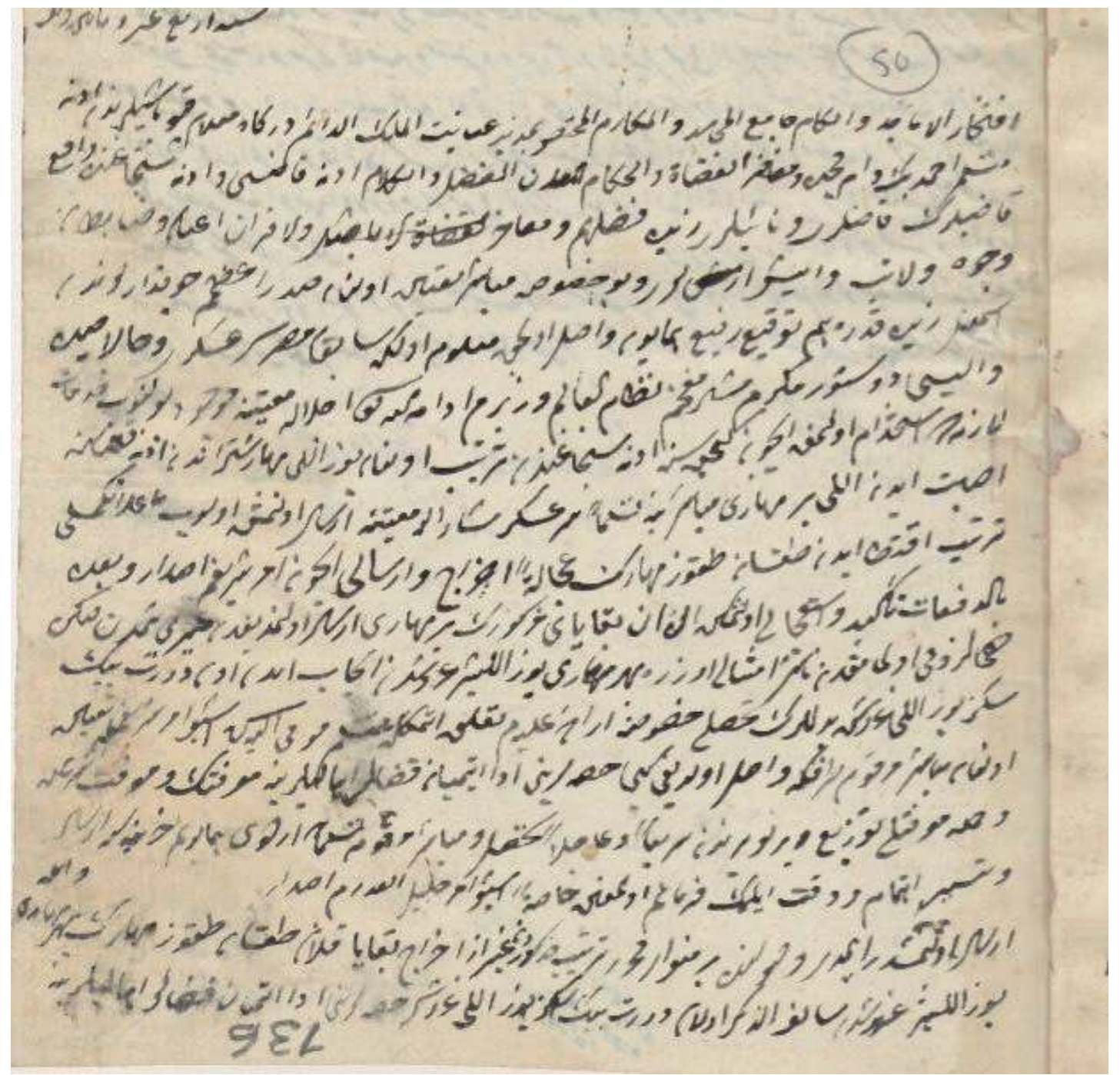

3: Adana Ş.S. 55, img. 68-69, sayfa 134-135, belge 50 


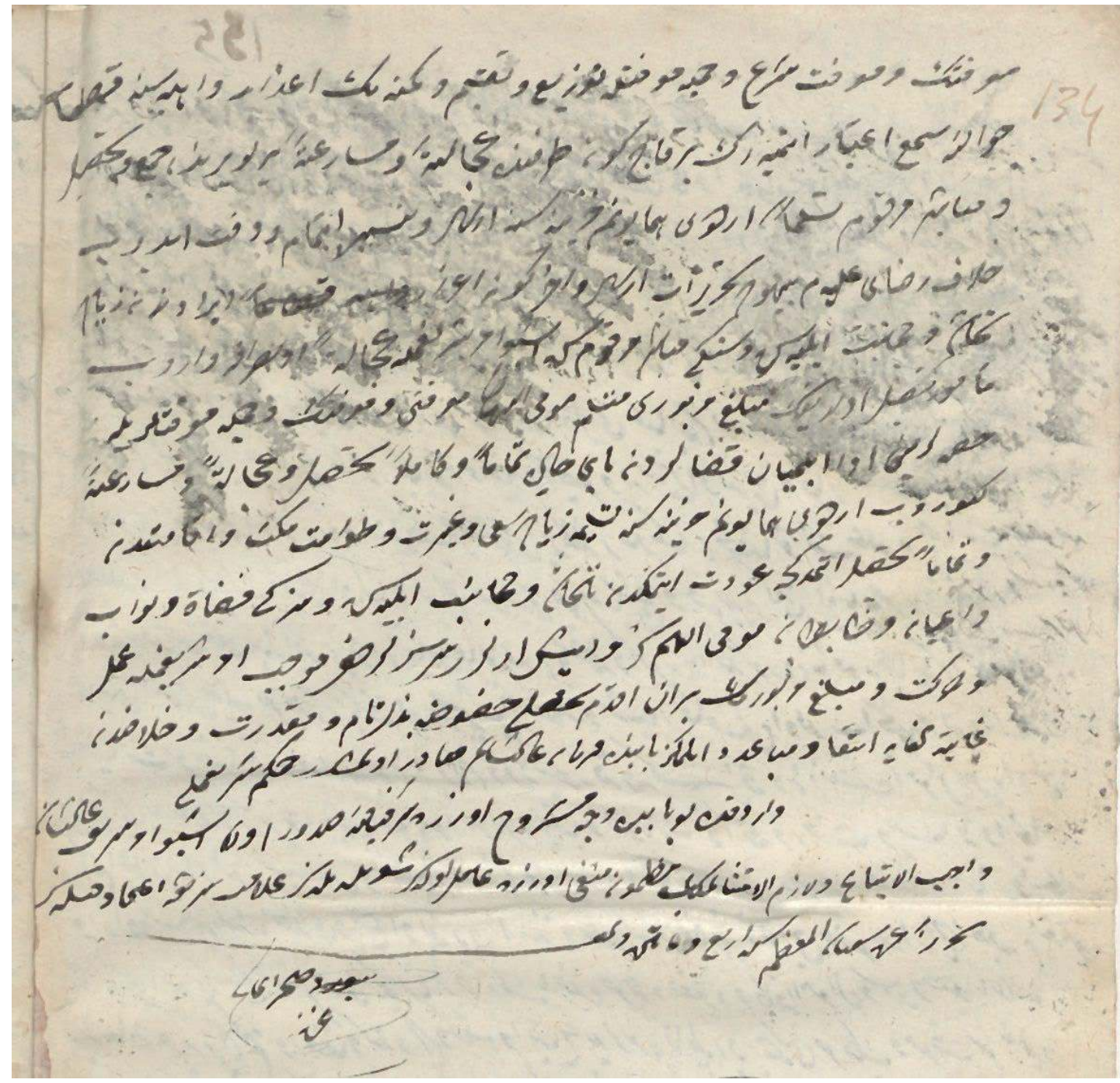

3: Adana Ş.S. 55, img. 68-69, sayfa 134-135, belge 50 


\section{(62)}

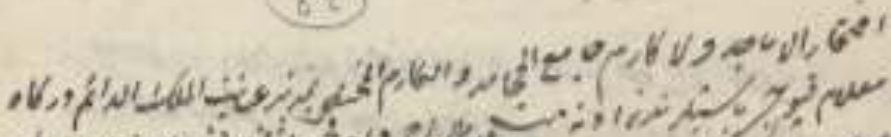

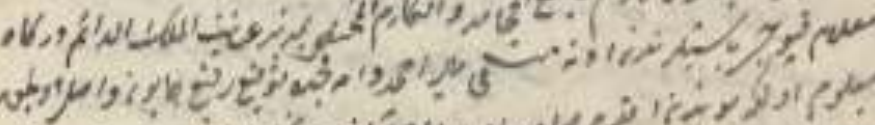

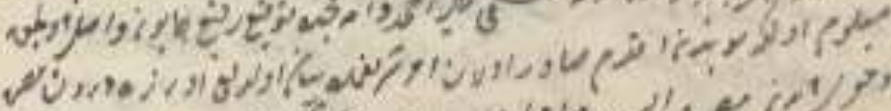

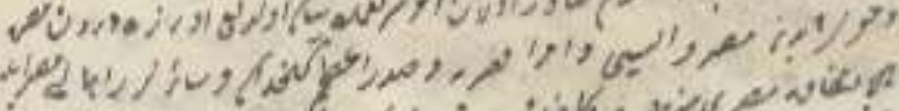

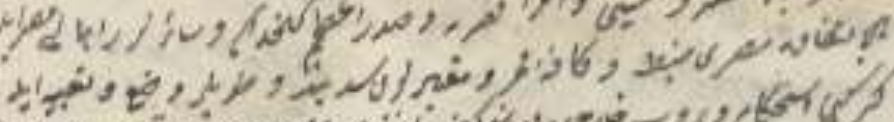

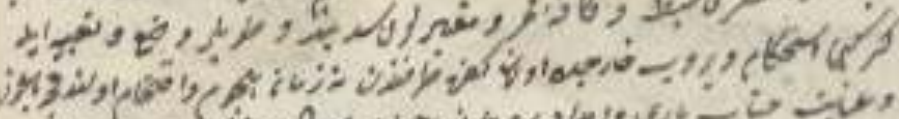

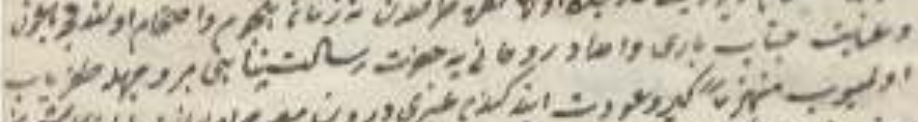
6001 is

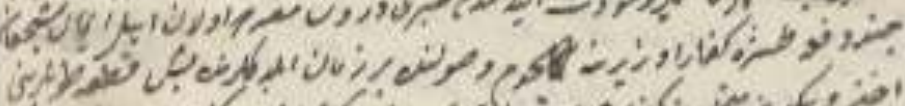

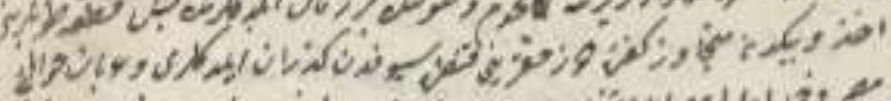

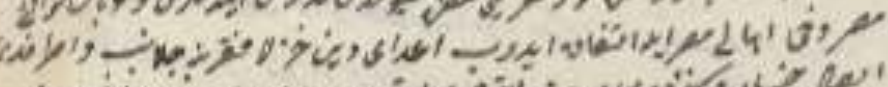

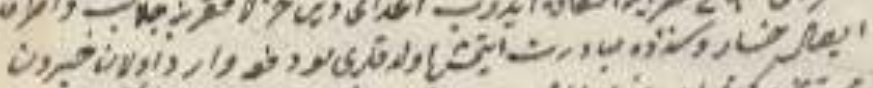
I

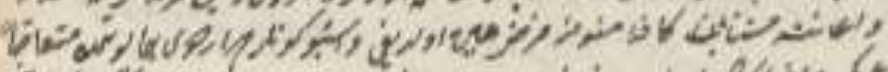

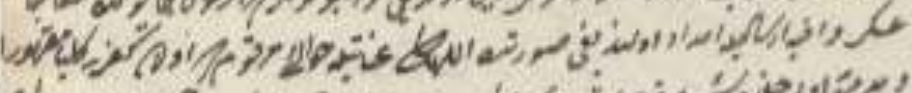

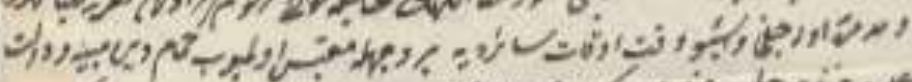

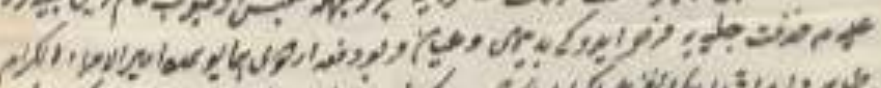

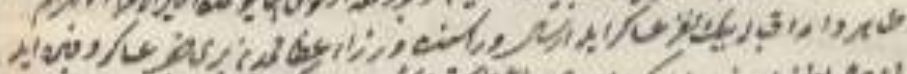

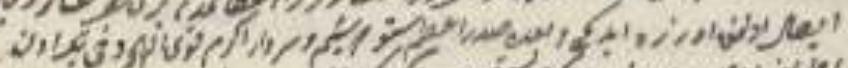
ipló

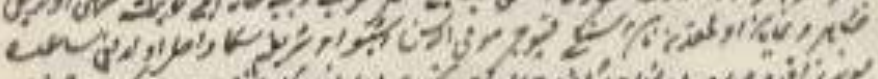
cis con 4 .

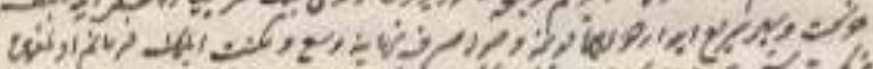
3)

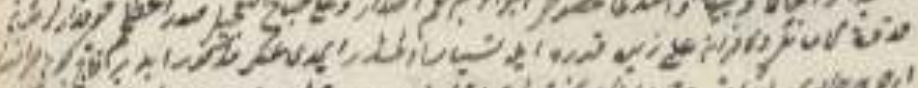

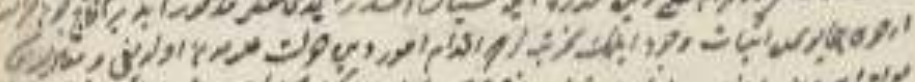

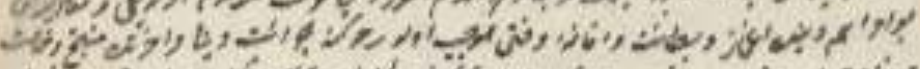

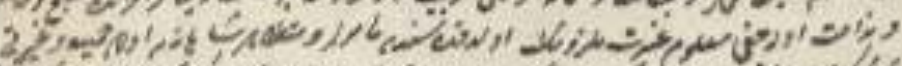

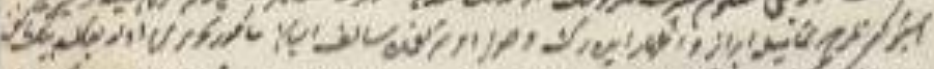

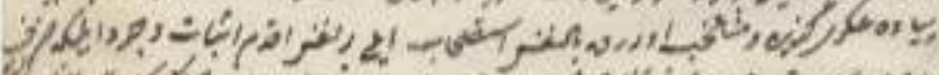

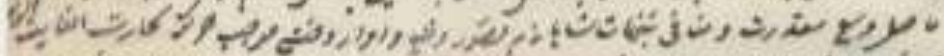

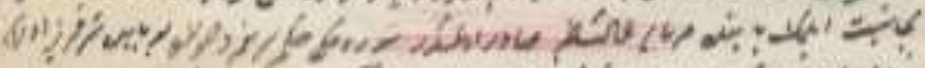

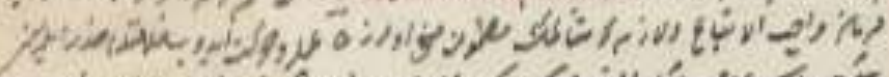

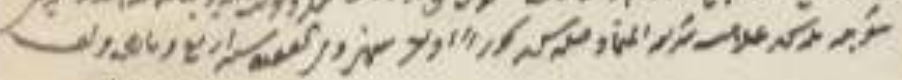
(1),

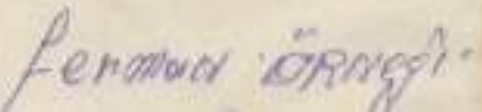

4: Adana Ş.S. 55, img. 64 , sayfa 126, belge 62 


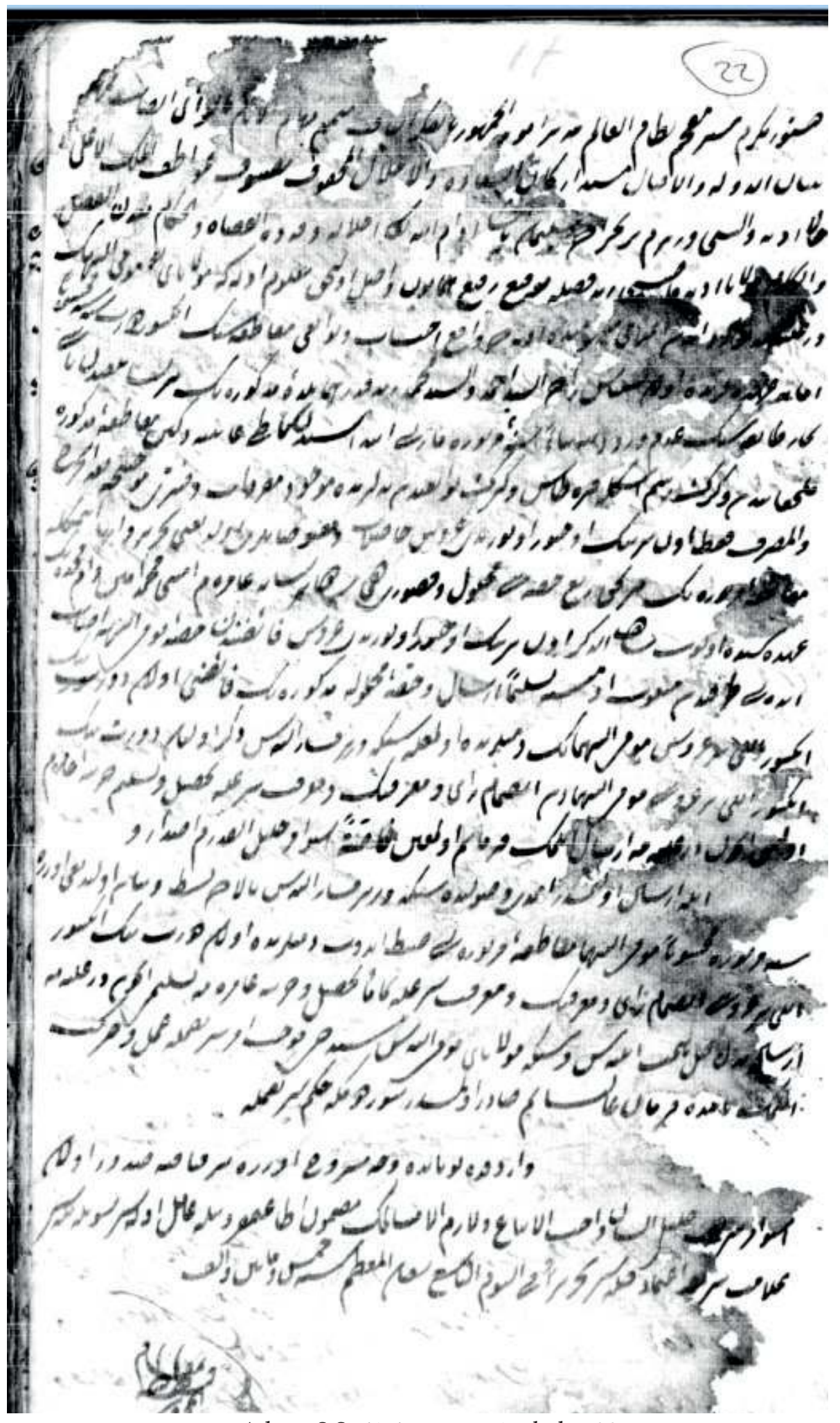

5: Adana Ş.S. 61, img. 5, s. 17, belge 22 


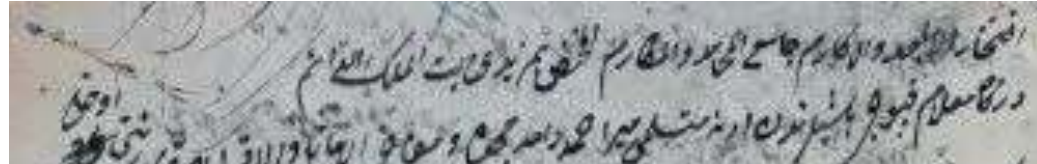

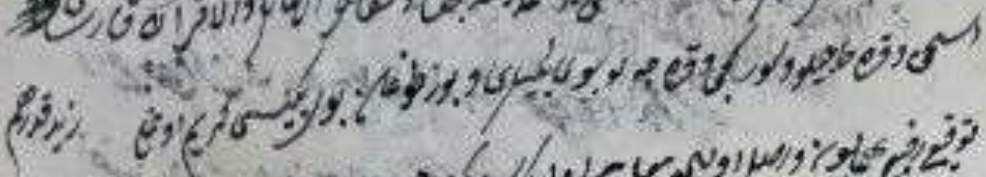

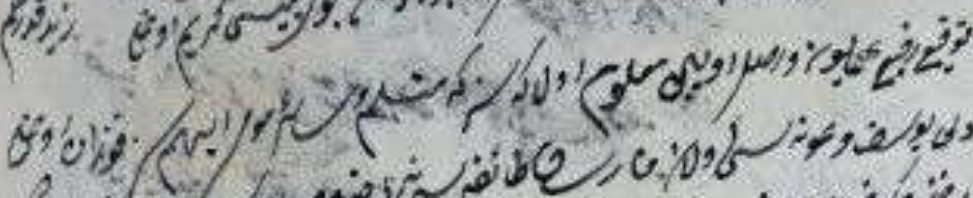

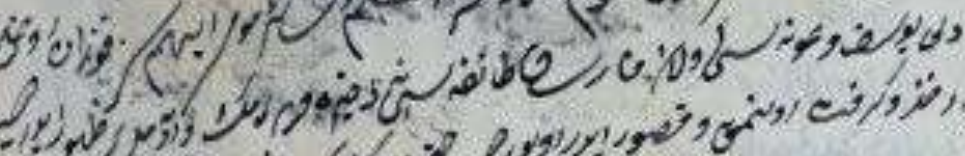

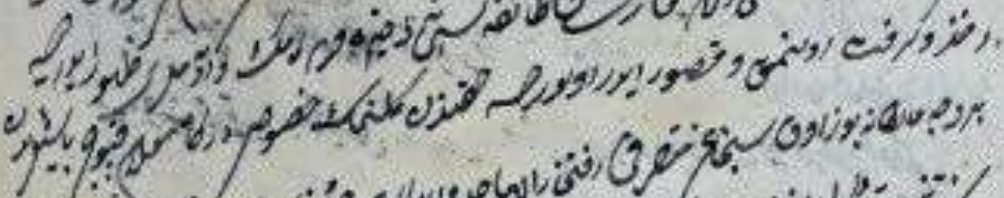
ק)

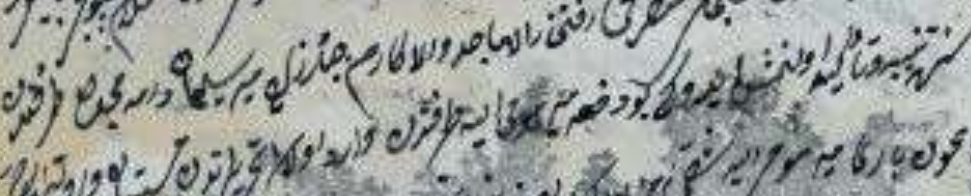

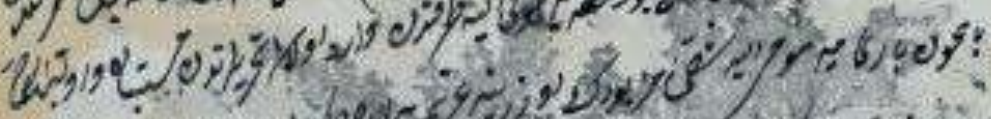

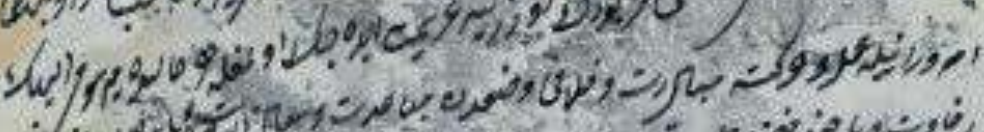

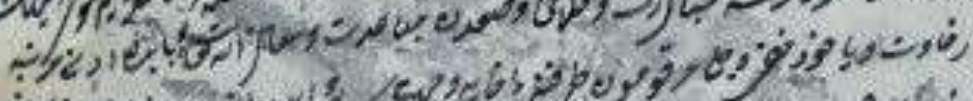

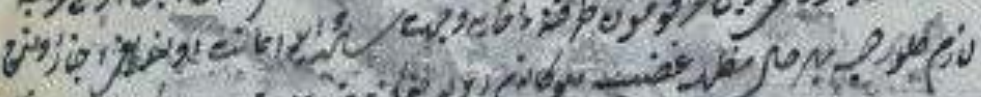

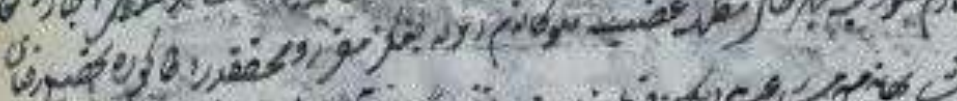

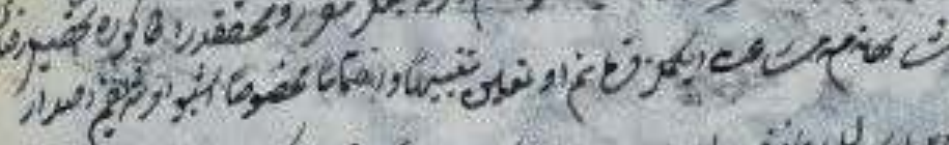

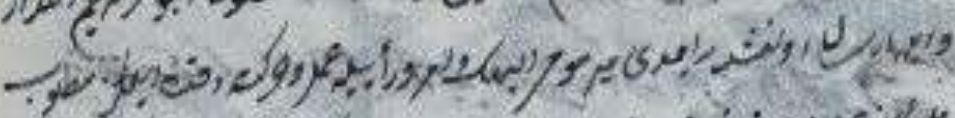

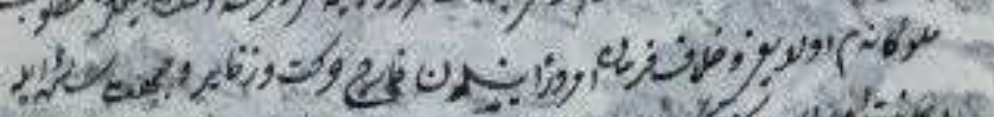

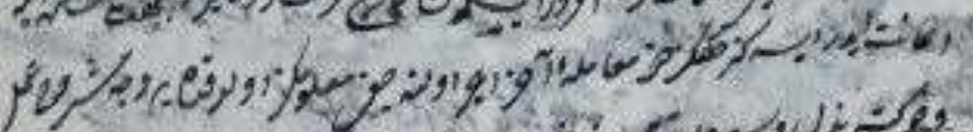

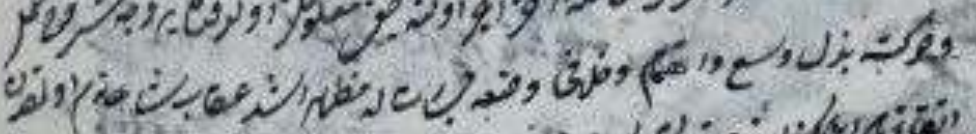

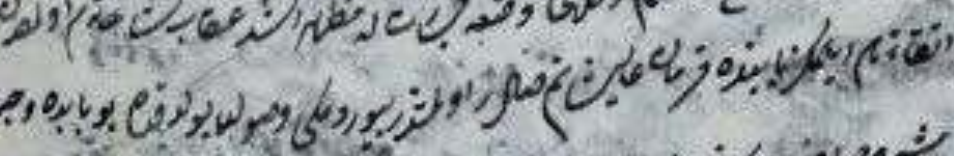
व $x y^{2}$ il

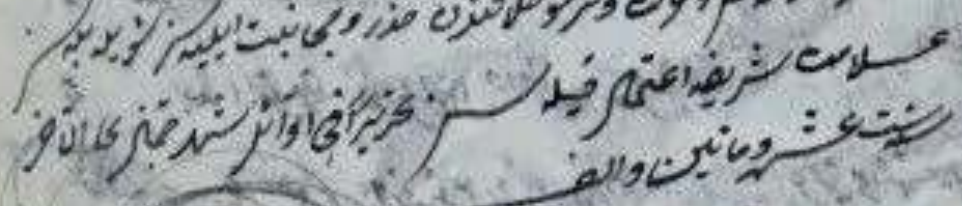
(esis $)=$ Not, 6: Adana Ş.S. 57, img. 54, sayfa 103, belge 136 


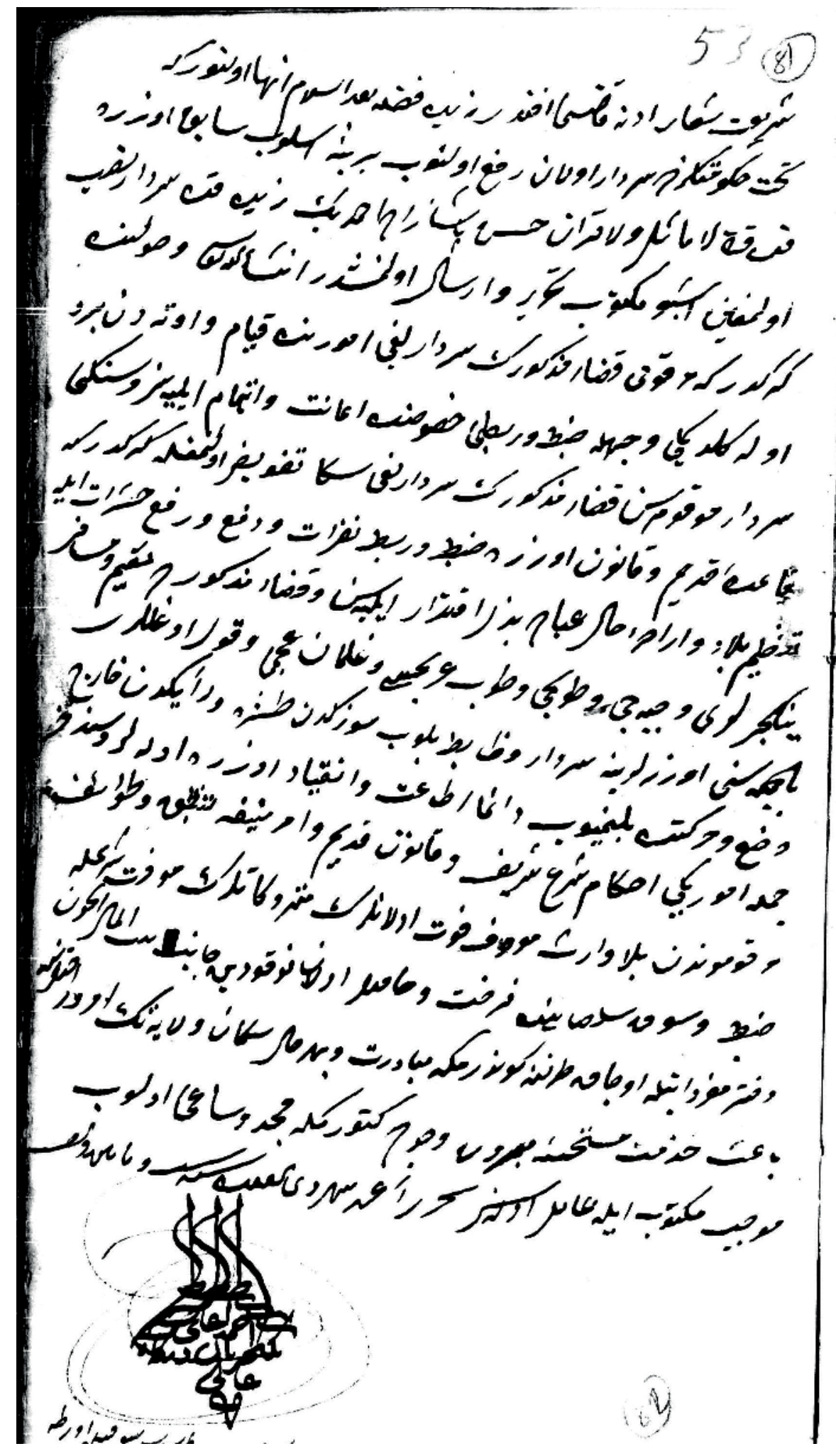

7: Adana Ş.S. 63 , img. 16, sayfa 53, belge 81 


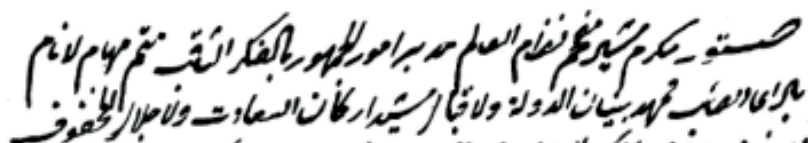

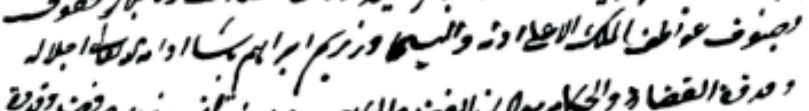

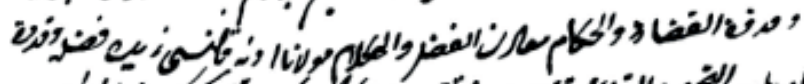

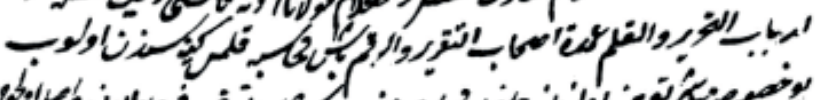

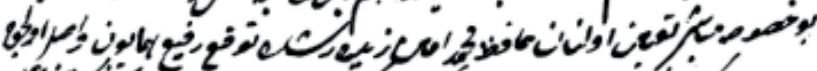

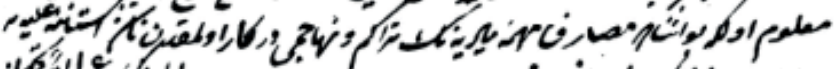

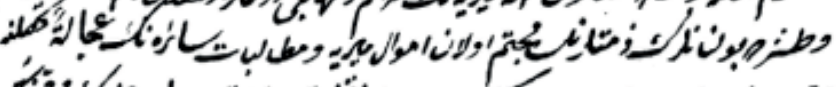

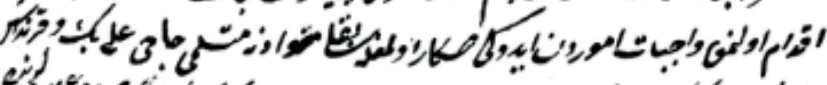

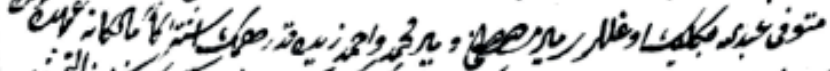

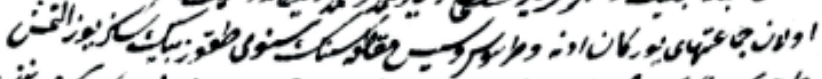

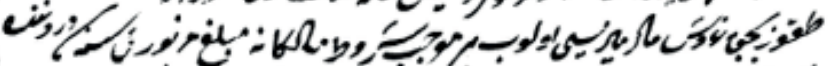

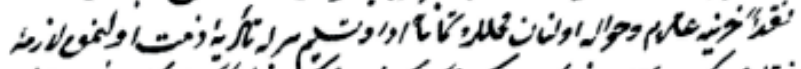

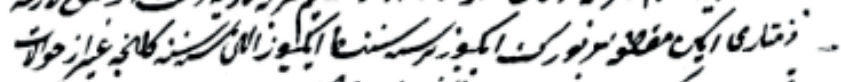

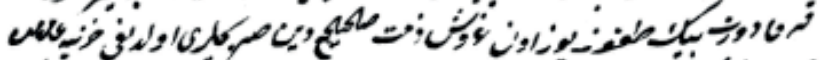

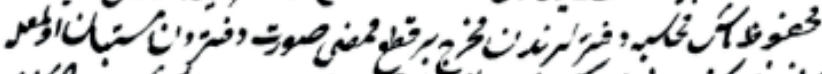

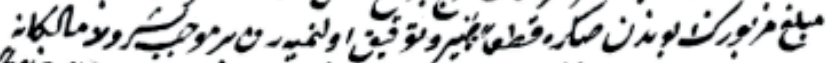

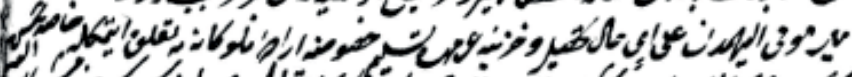

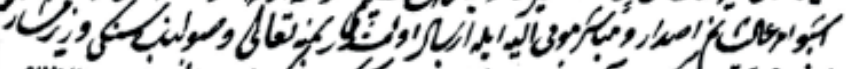

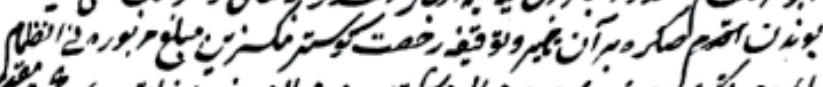

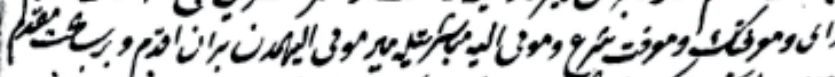

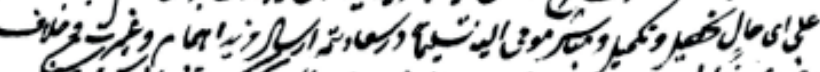
رضى

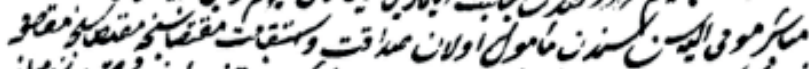

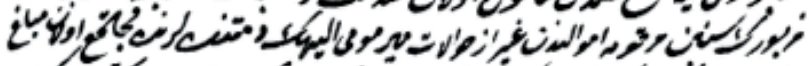

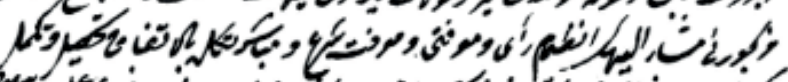

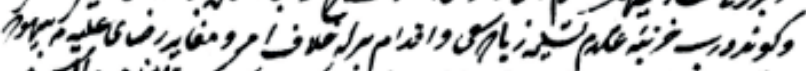

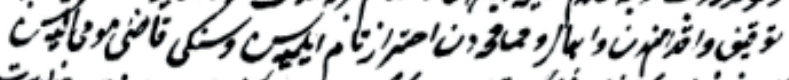
ون

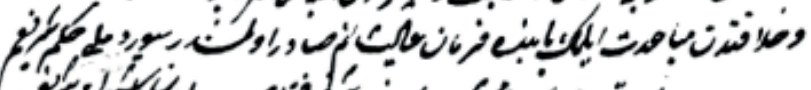

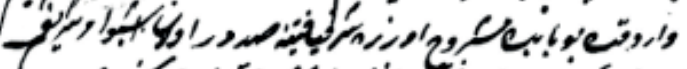

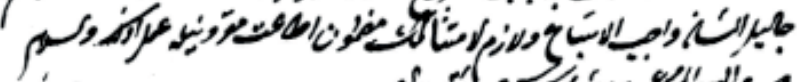

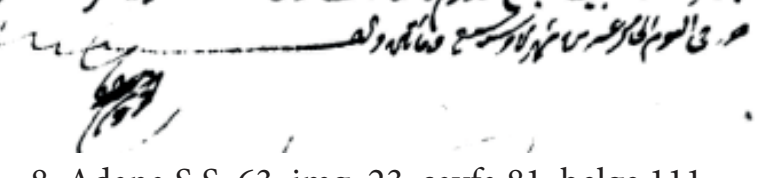

8: Adana Ş.S. 63, img. 23, sayfa 81, belge 111 


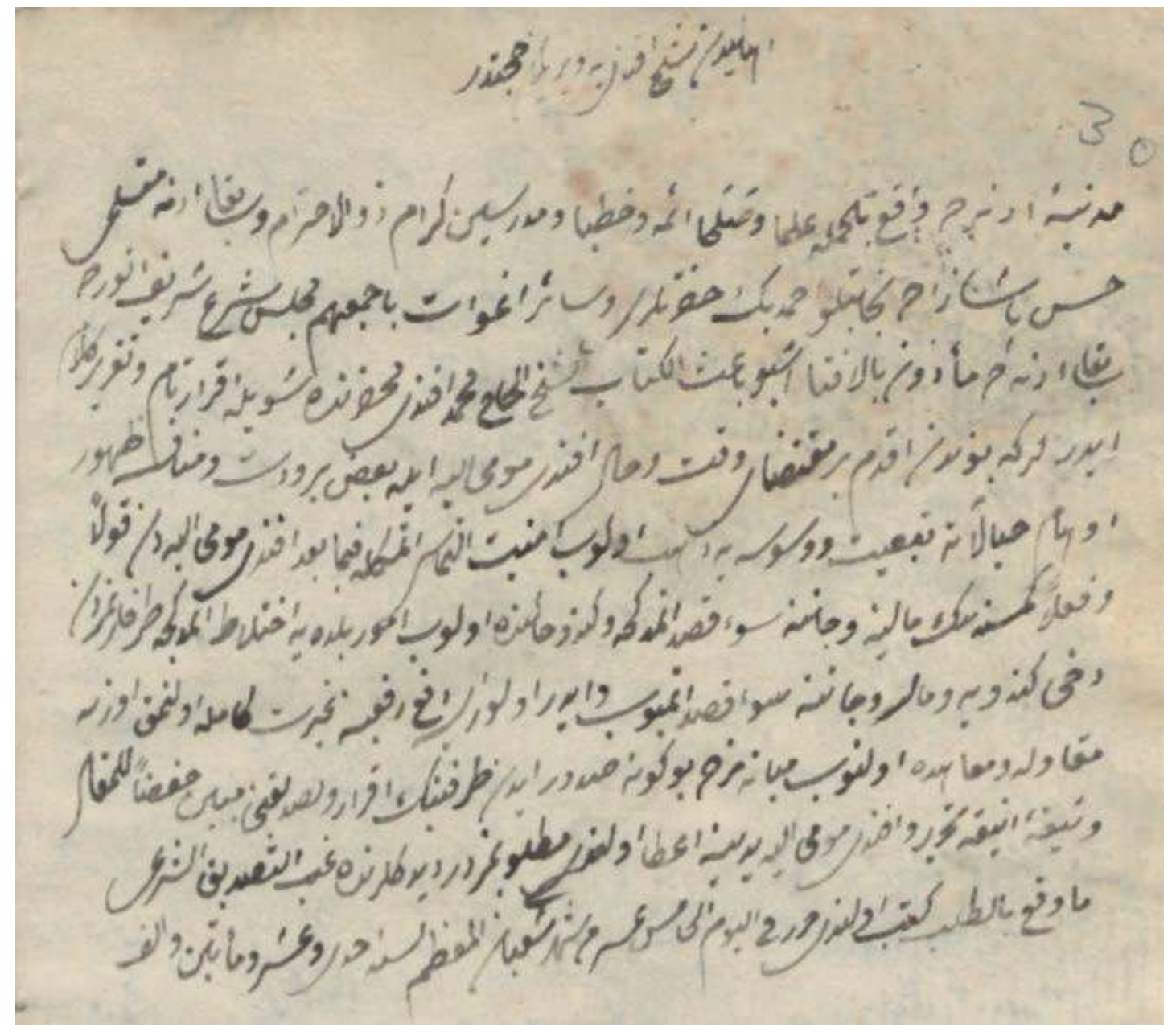

9: Adana Ş.S. 56, img. 23, sayfa 57, belge 30 


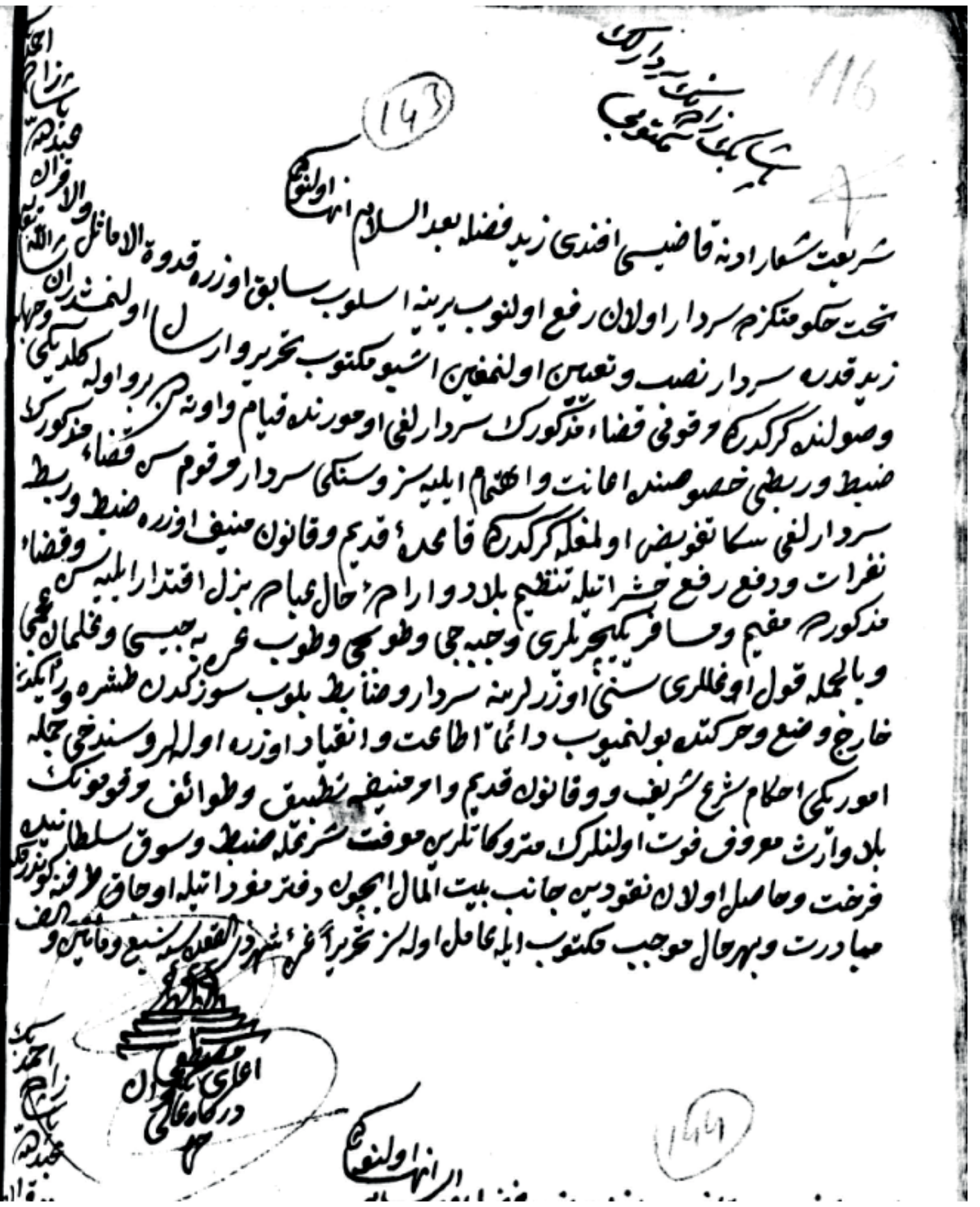

10: Adana Ş.S. 63, img. 32, sayfa 116, belge 143 


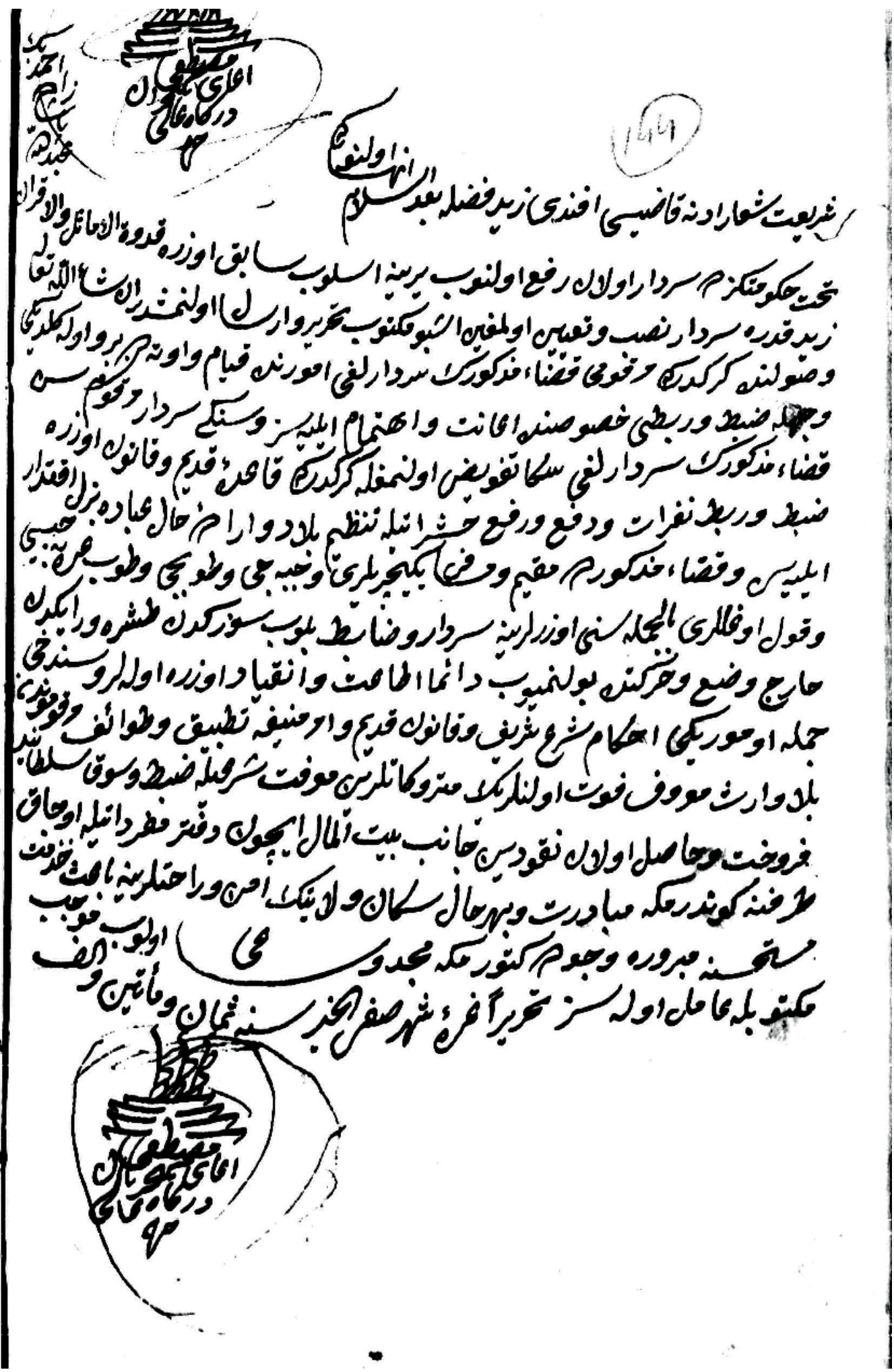

11: Adana Ş.S. 63, img. 32, sayfa 116, belge 144 


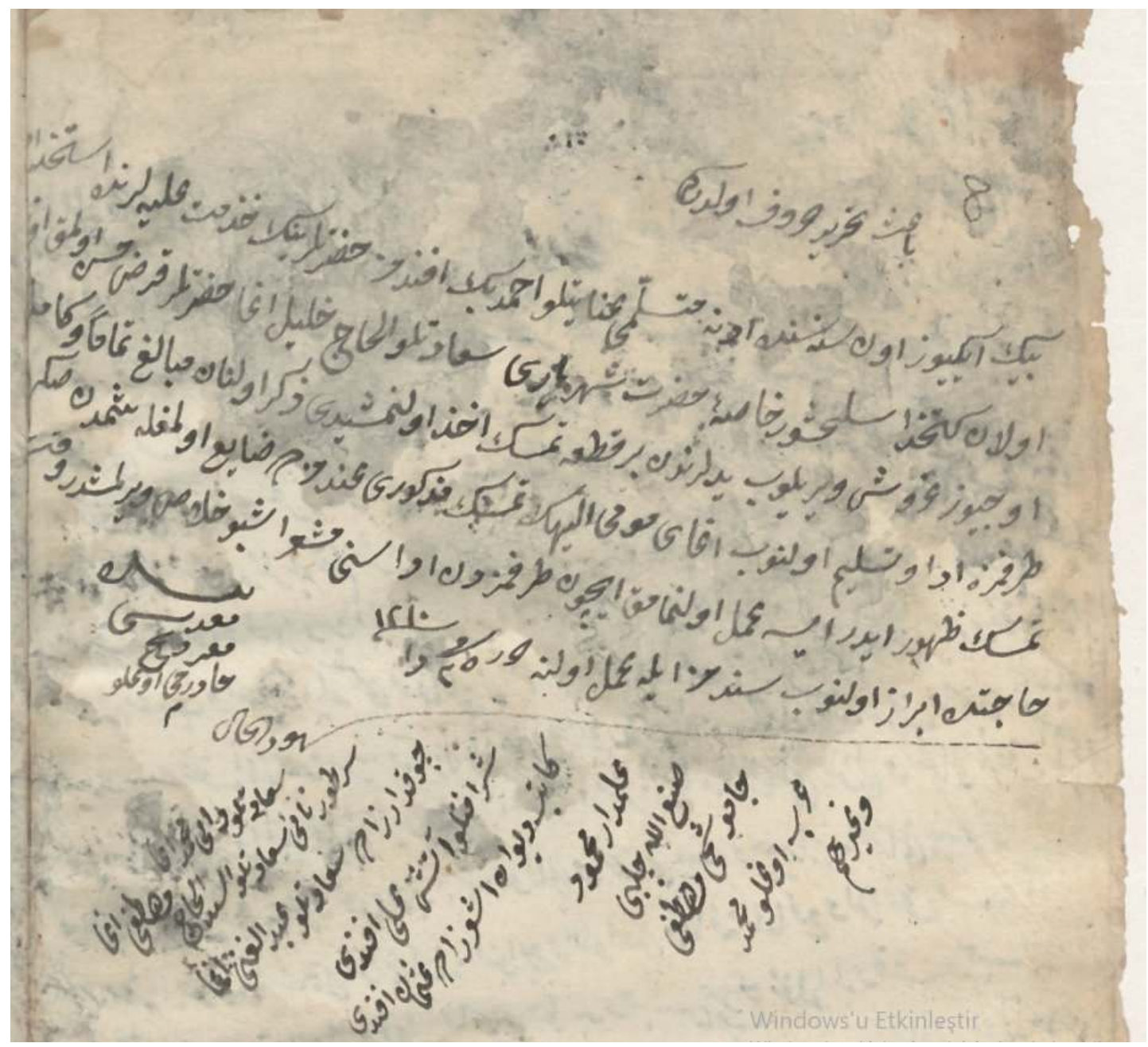

12: Adana Ş.S. 56 , img. 30 , sayfa 71 , belge 8 


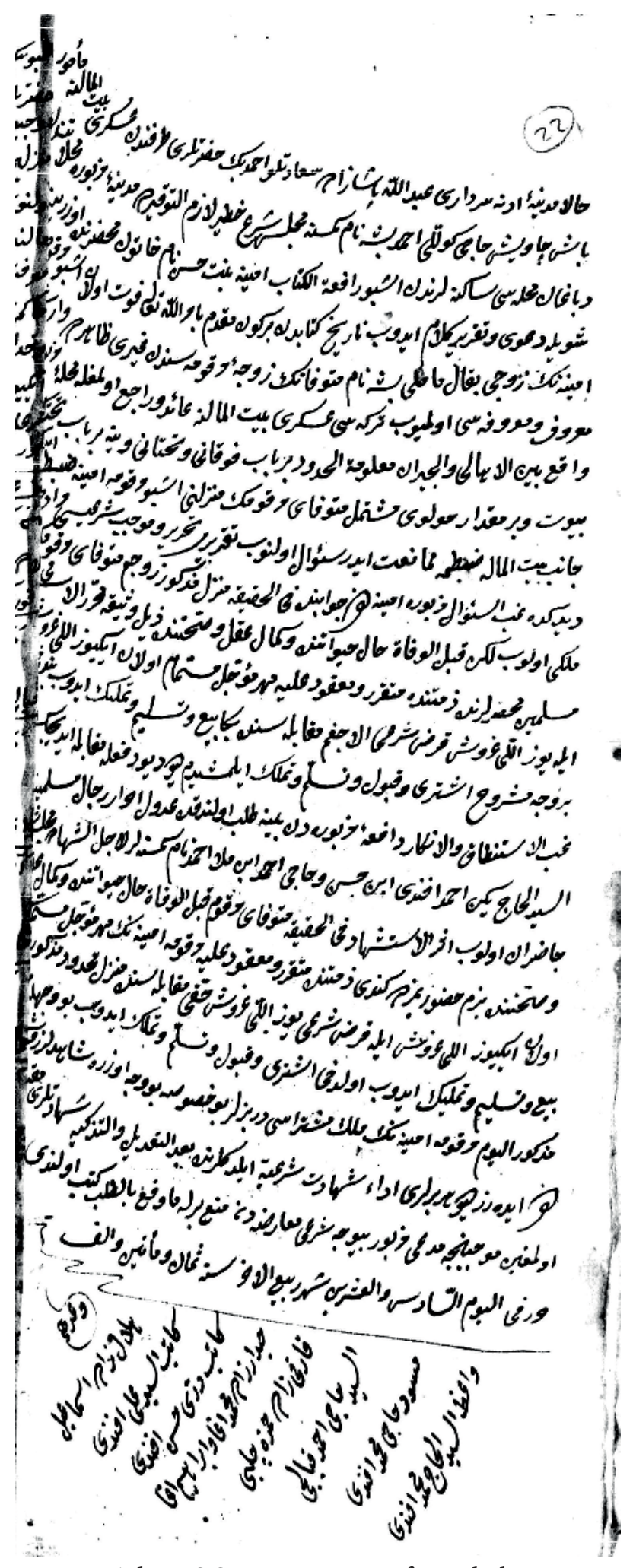

13: Adana Ş.S. 63 , img. 7, sayfa 20, belge 22 


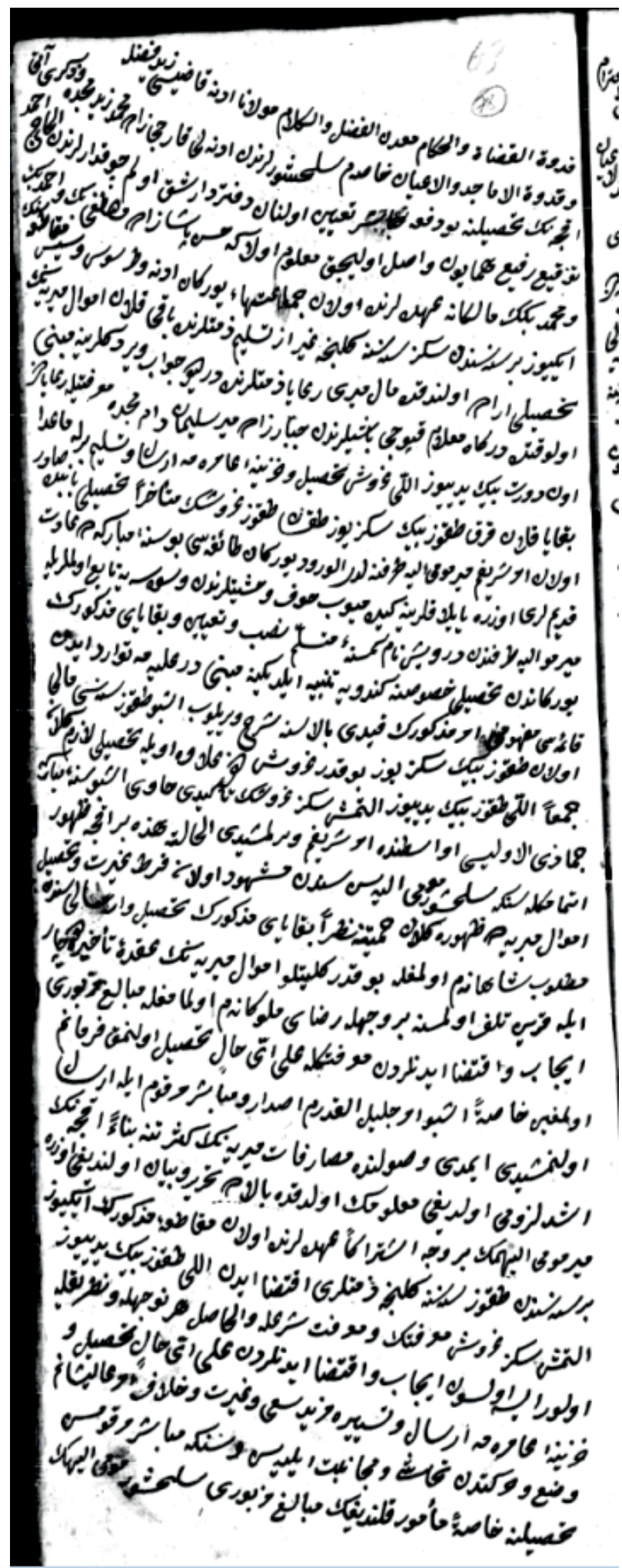

14: Adana Ş.S. 66, img. 13, sayfa 63, belge 78 


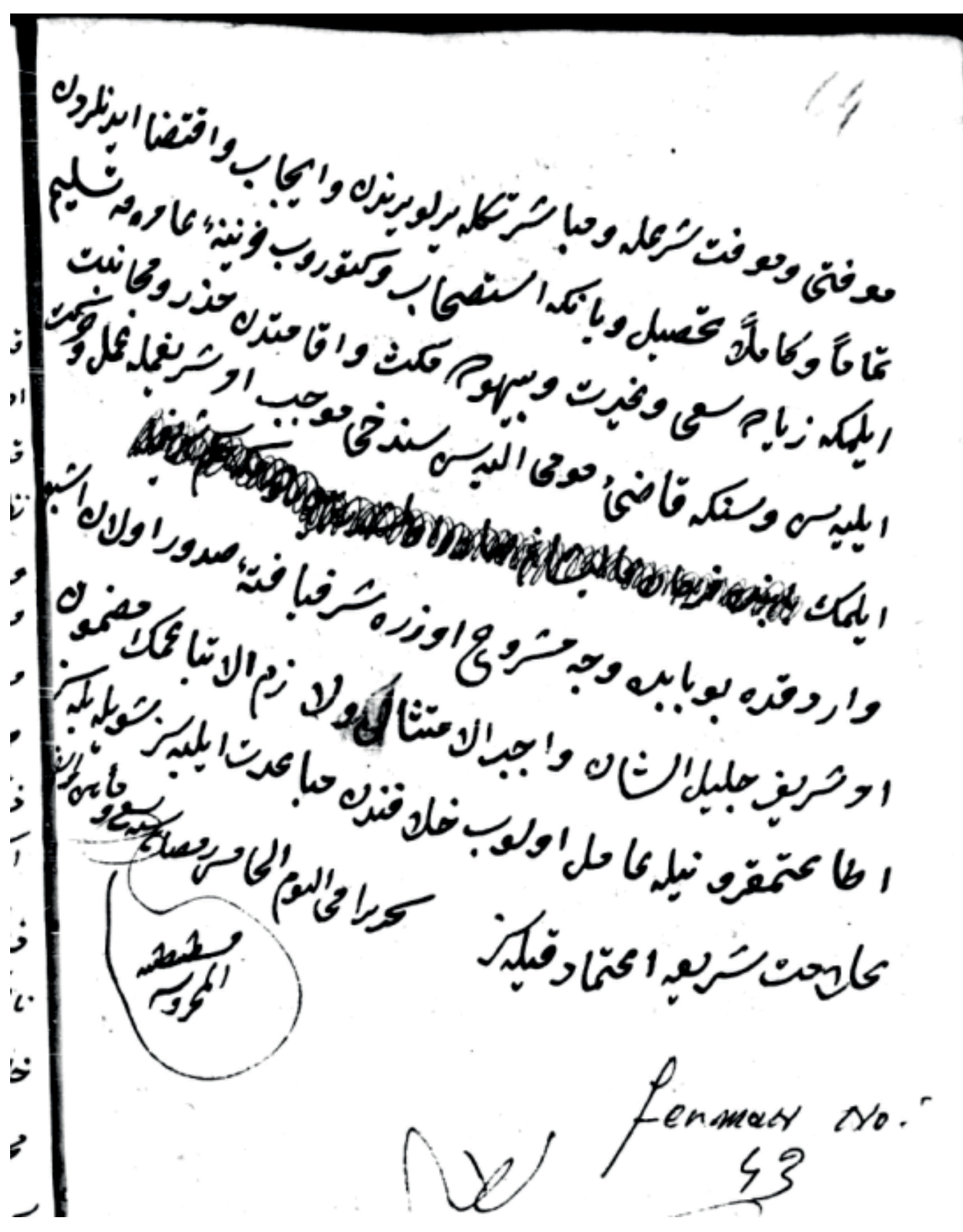

14: Adana Ş.S. 66, img. 13, sayfa 63, belge 78 


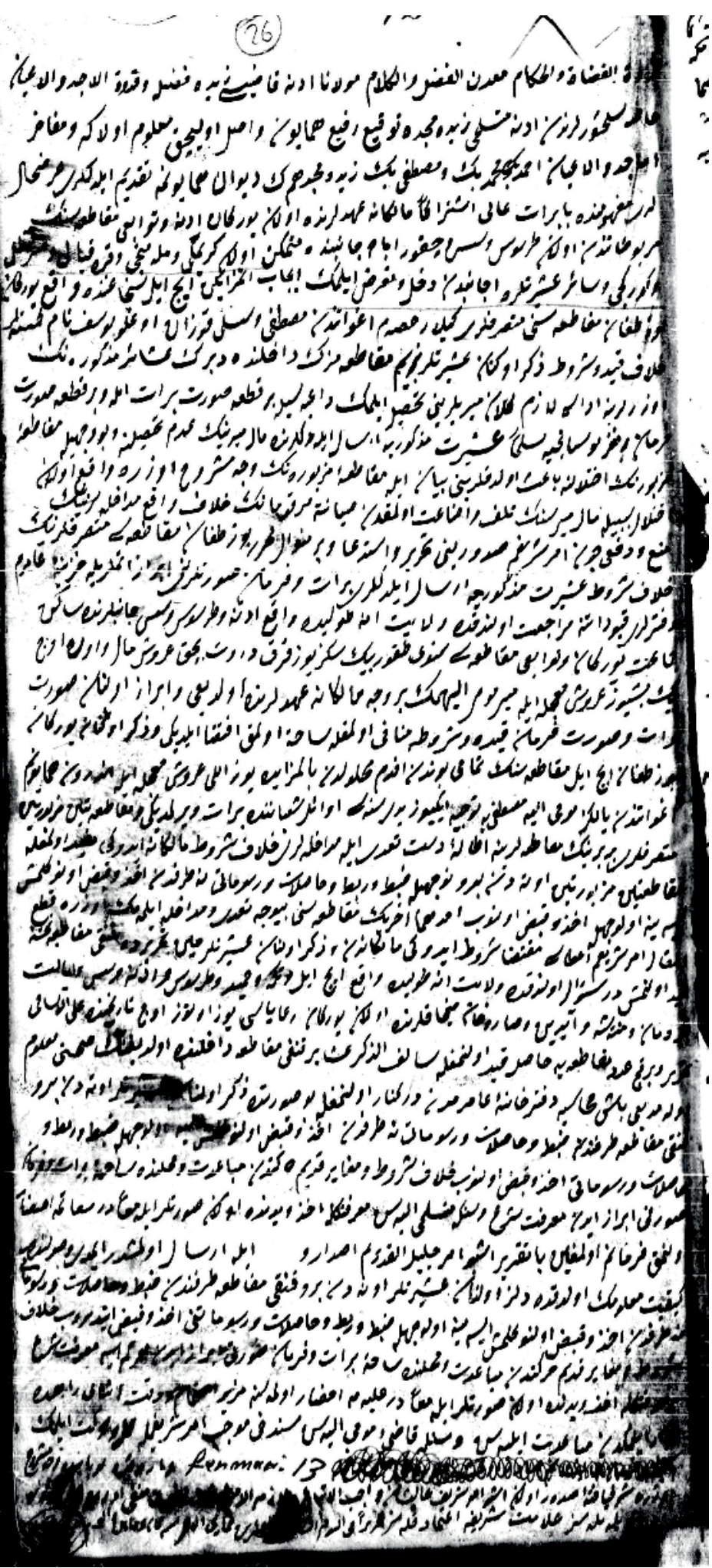

15: Adana Ş.S. 66, sayfa 21, img. 34, belge 26 


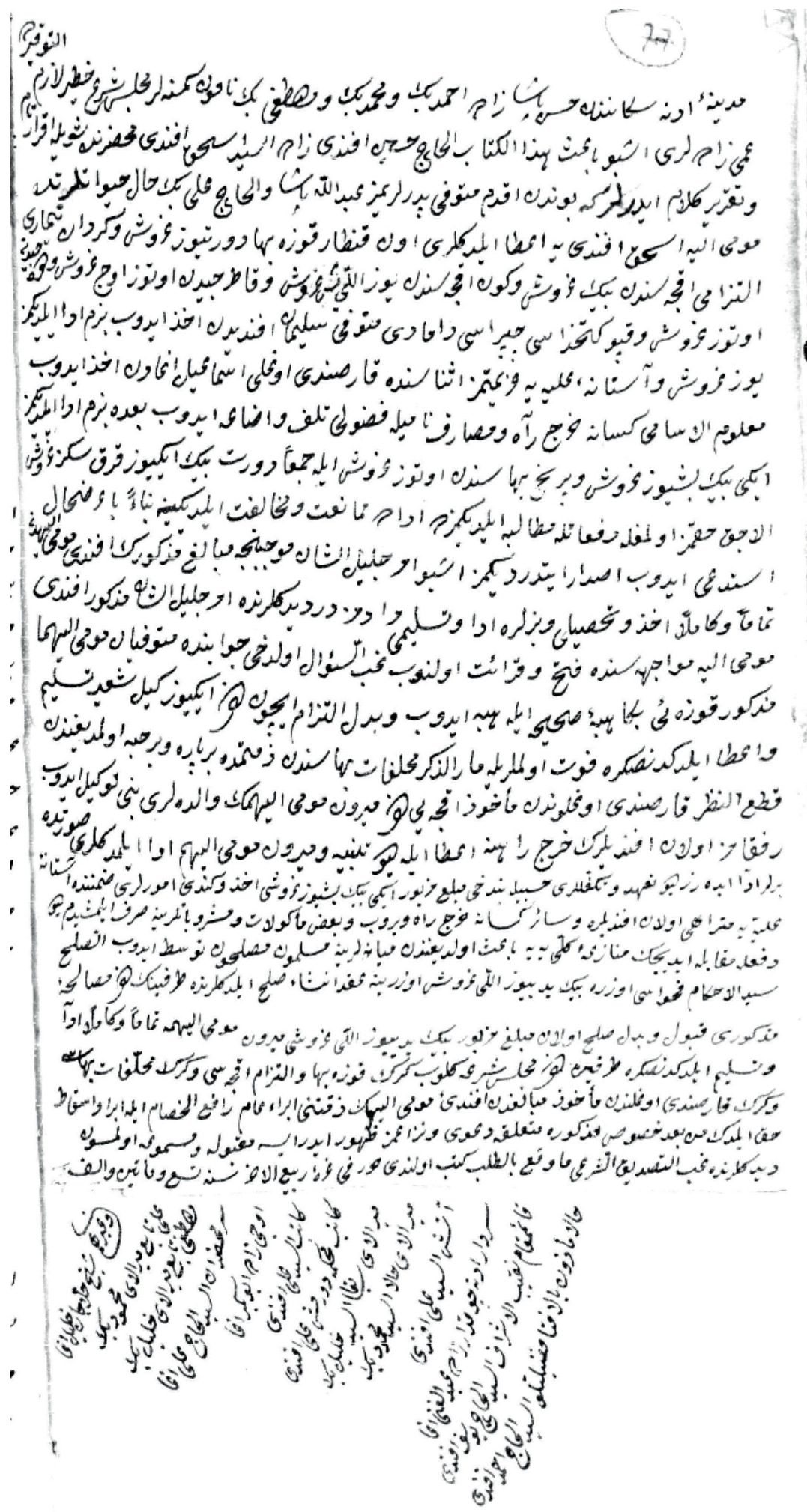

16: Adana Ş.S. 62, img. 4, sayfa 32 belge 77-78 


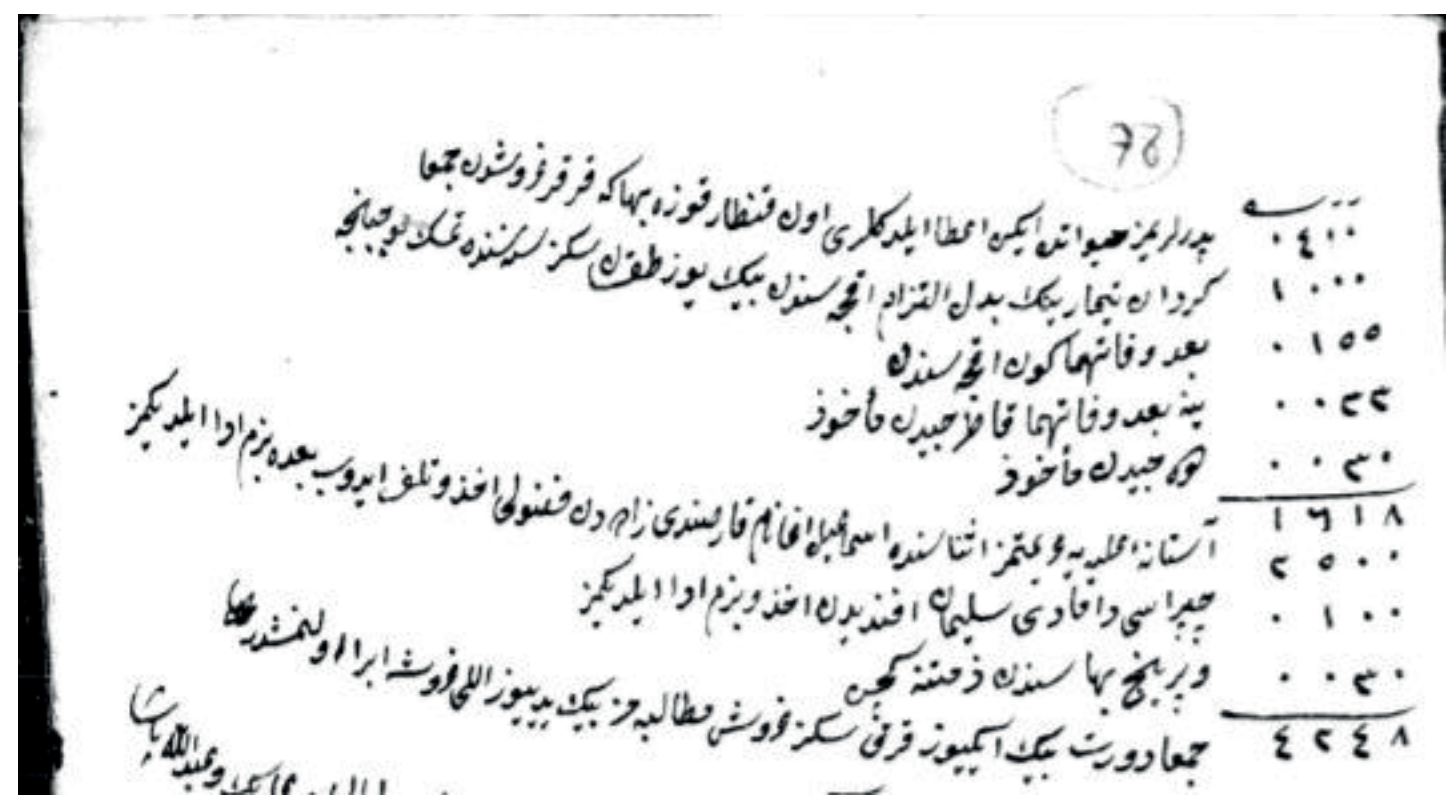

16: Adana Ş.S. 62 , img. 4, sayfa 32 belge $77-78$ 


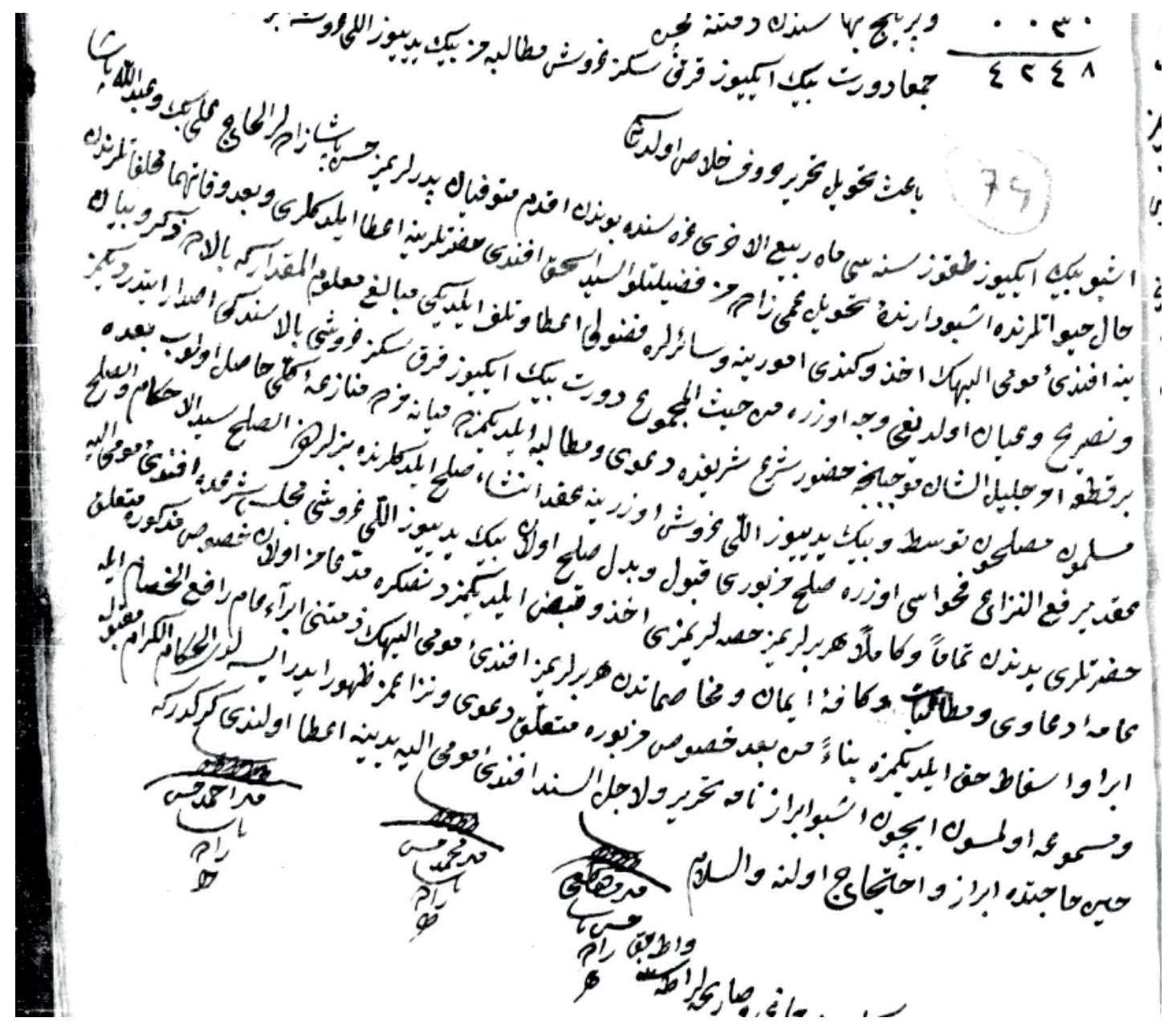

17: Adana Ş.S. 62, img. 4, sayfa 33, belge 79 


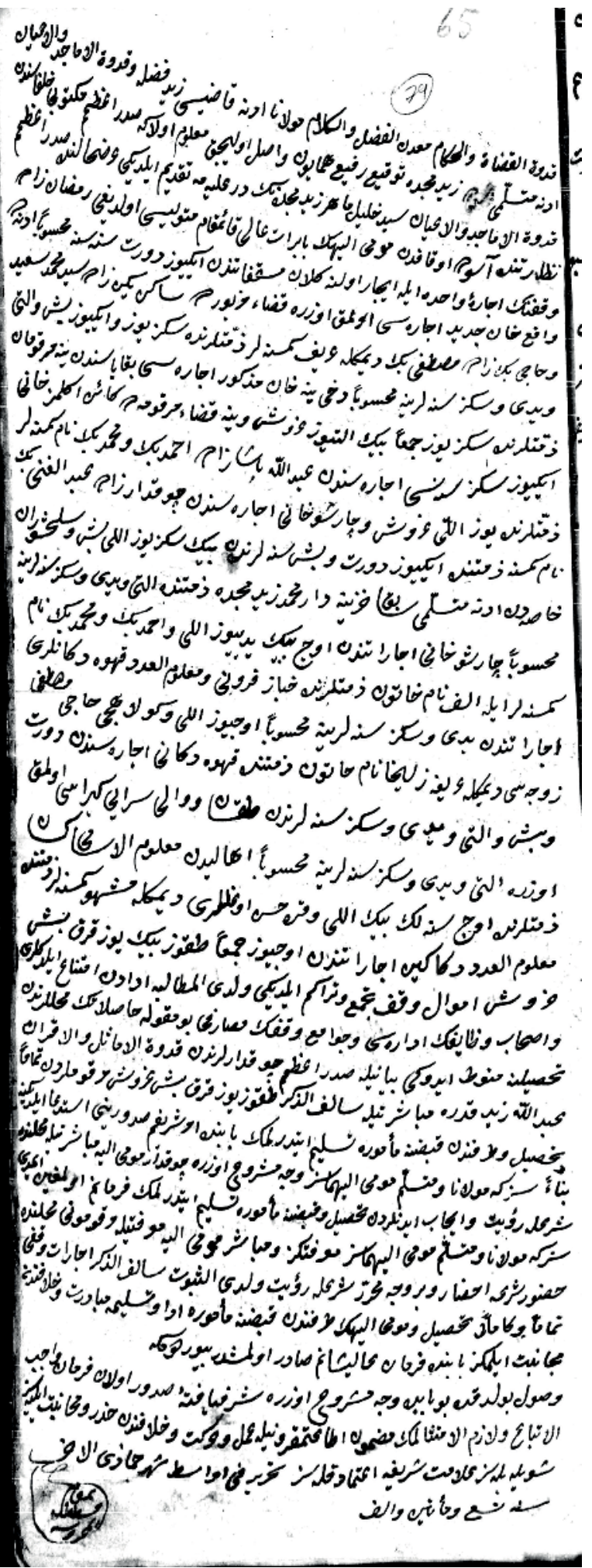

18: Adana Ş.S. 66, img. 12, sayfa 65, belge 79 


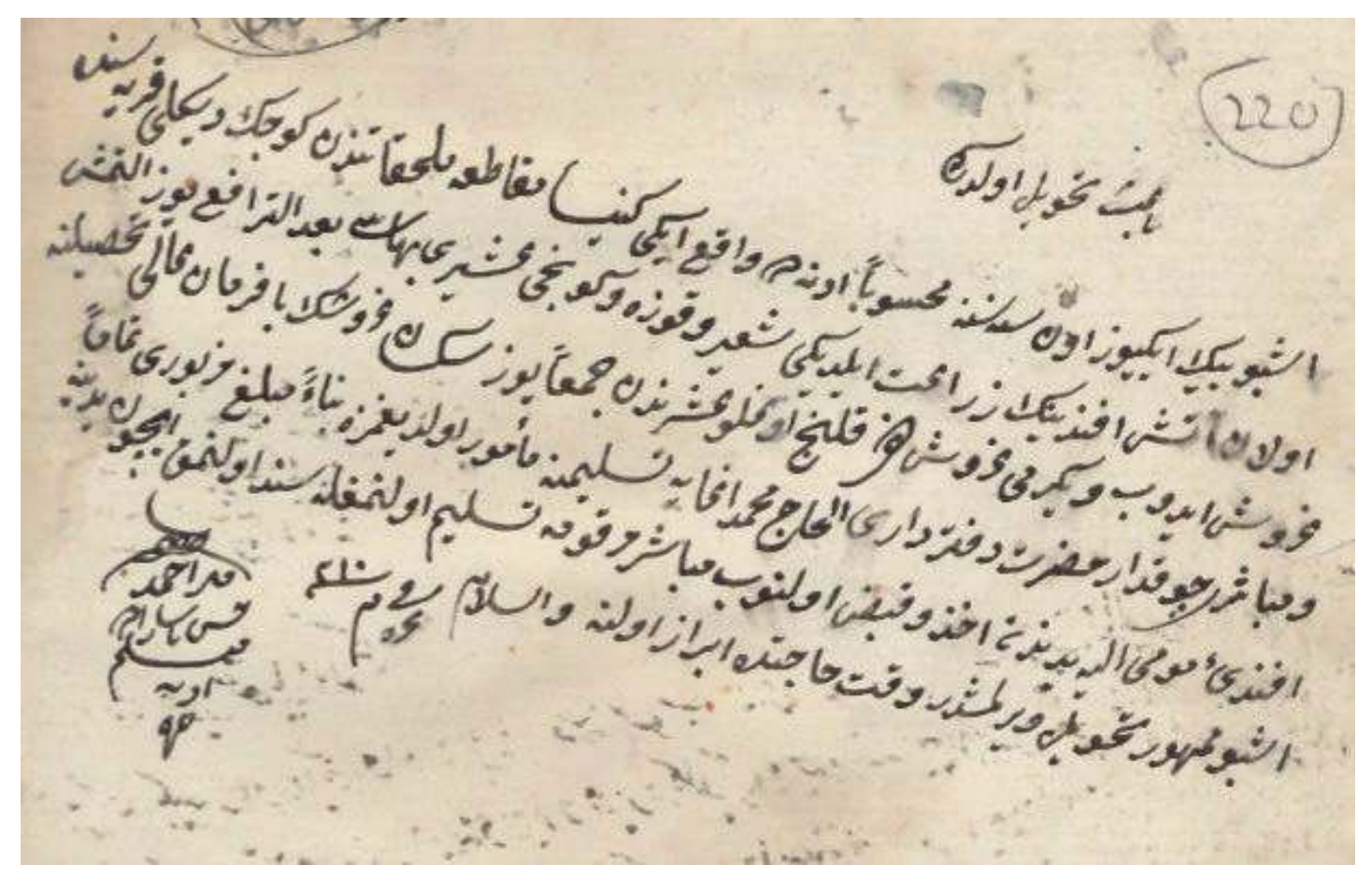

19: Adana Ş.S. 55, img. 9, sayfa 16, belge 220 


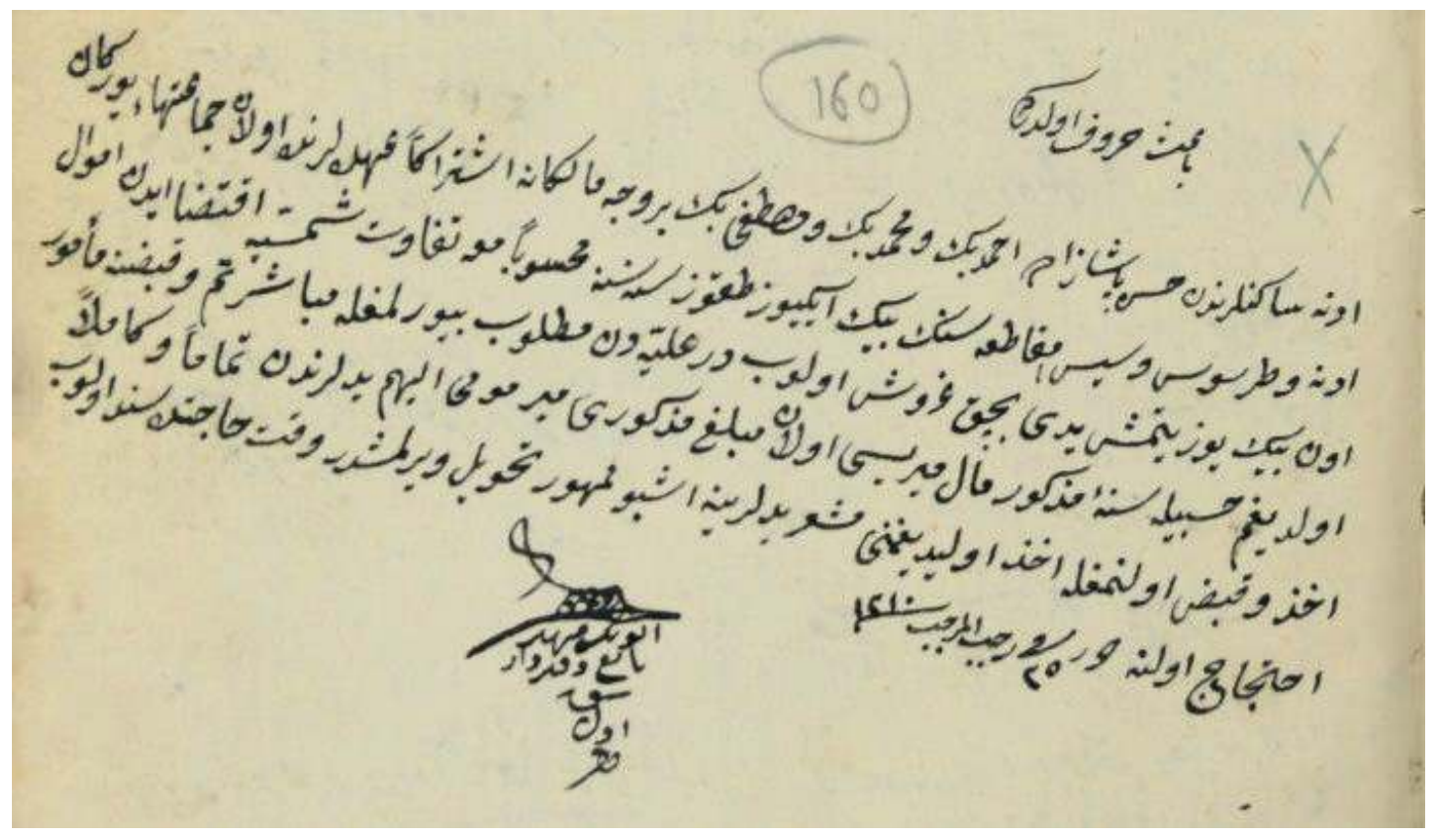

20: Adana Ş.S. 64, img. 60, sayfa 71. belge 160 


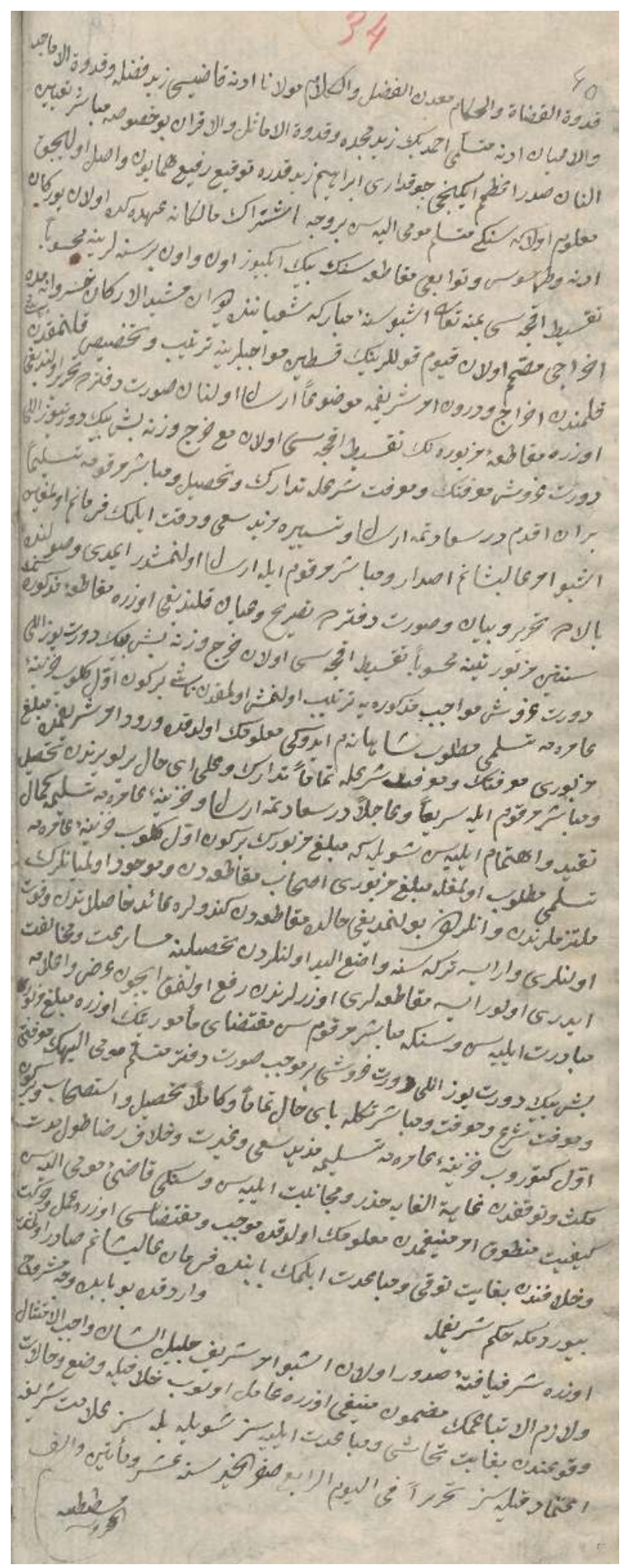

21: Adana Ş.S. 56 , img. 18 , sayfa 34 , belge 40 


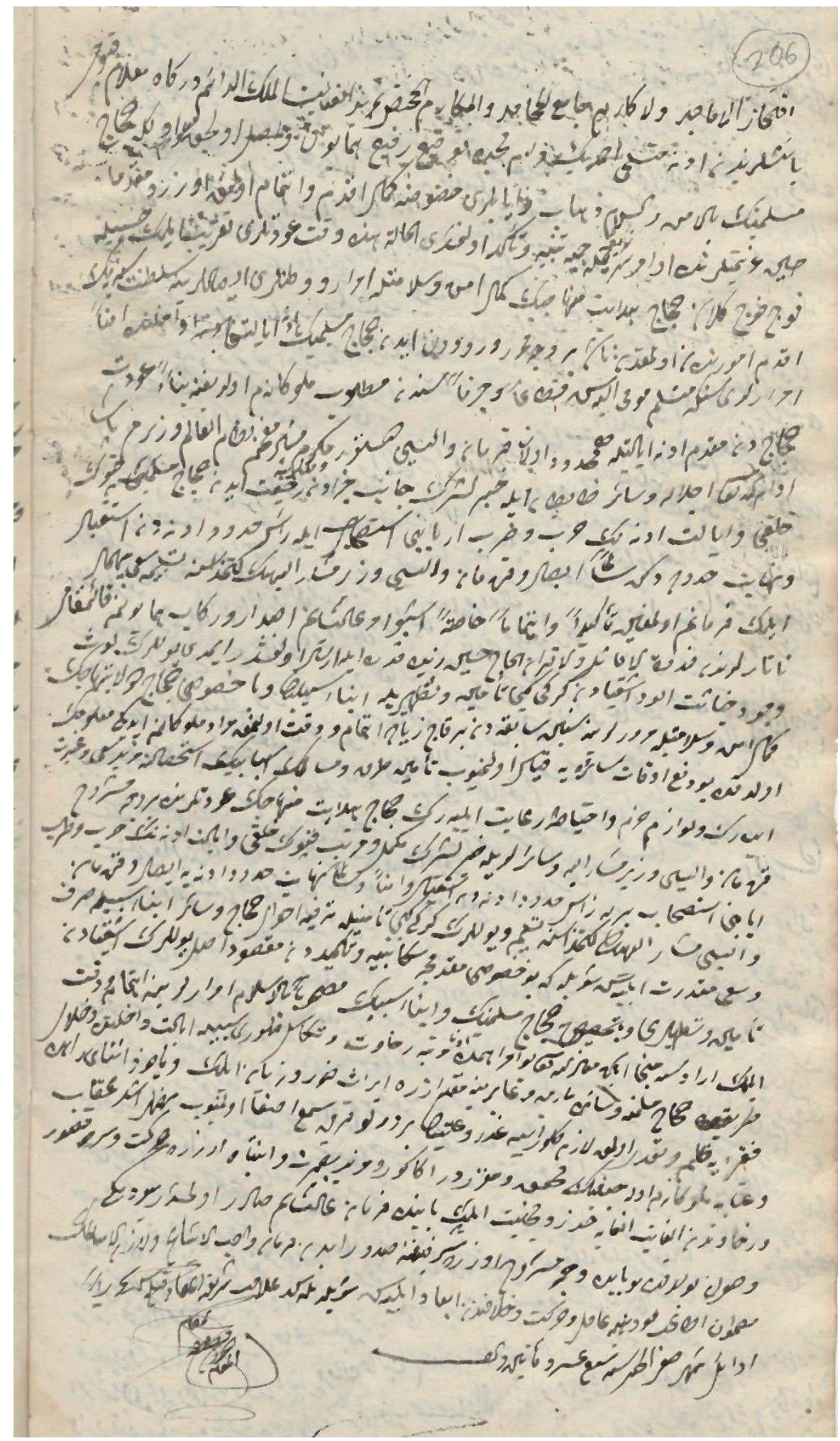

22: Adana Ş.S. 48, img. 66, sayfa 128, belge 206 


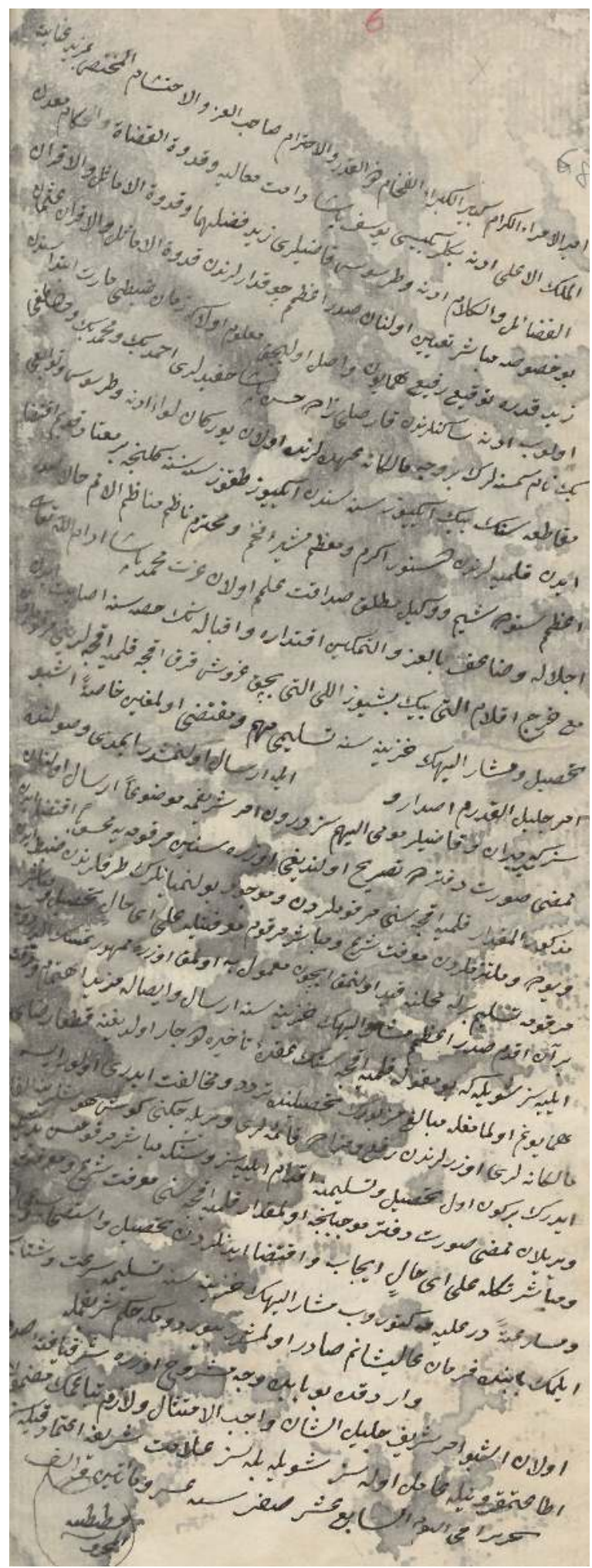

23: Adana Ş.S. 56, img. 04, sayfa 06, belge 68 


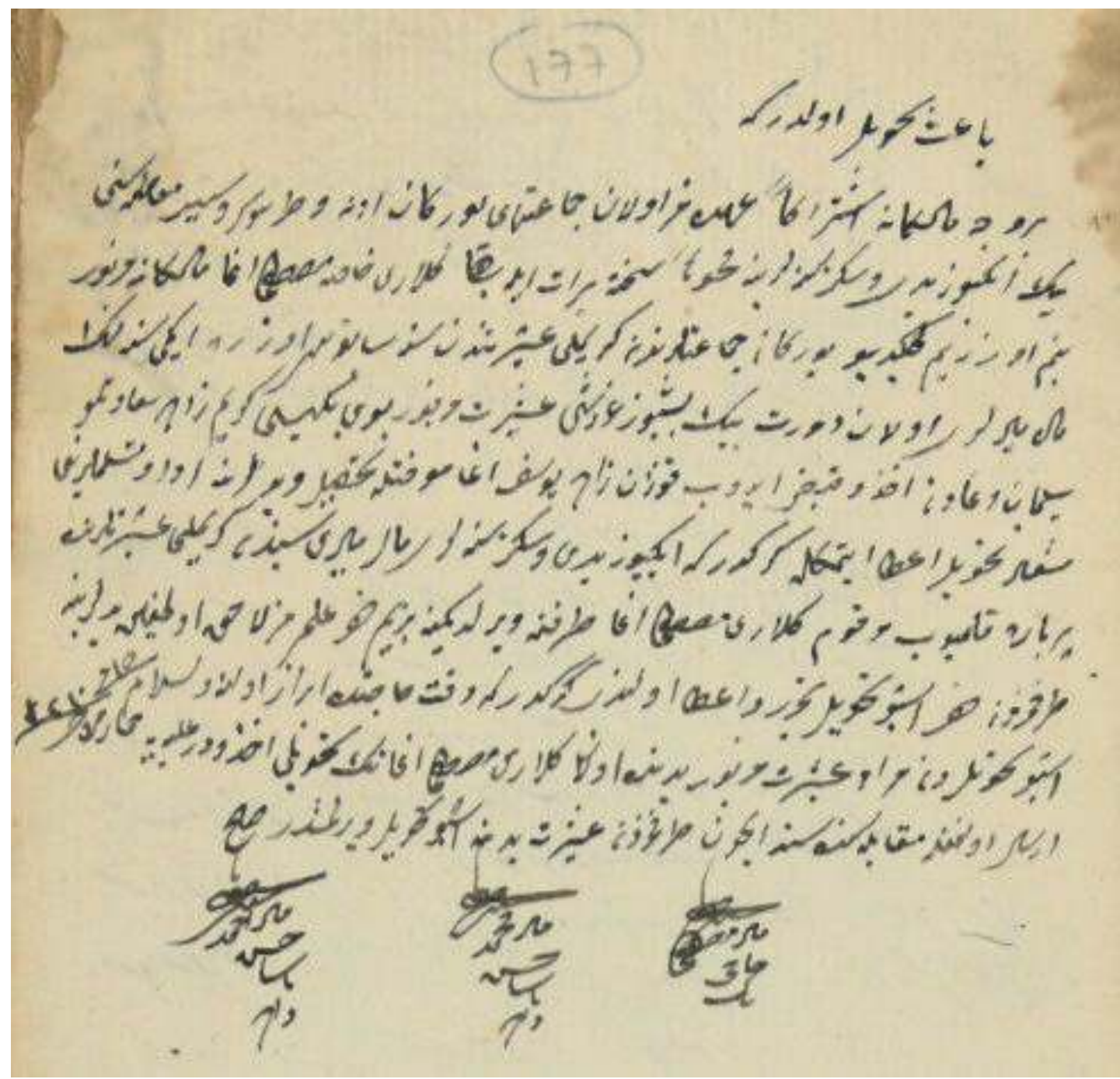

24: Adana Ş.S. 64, img. 65, sayfa 61, belge 177 


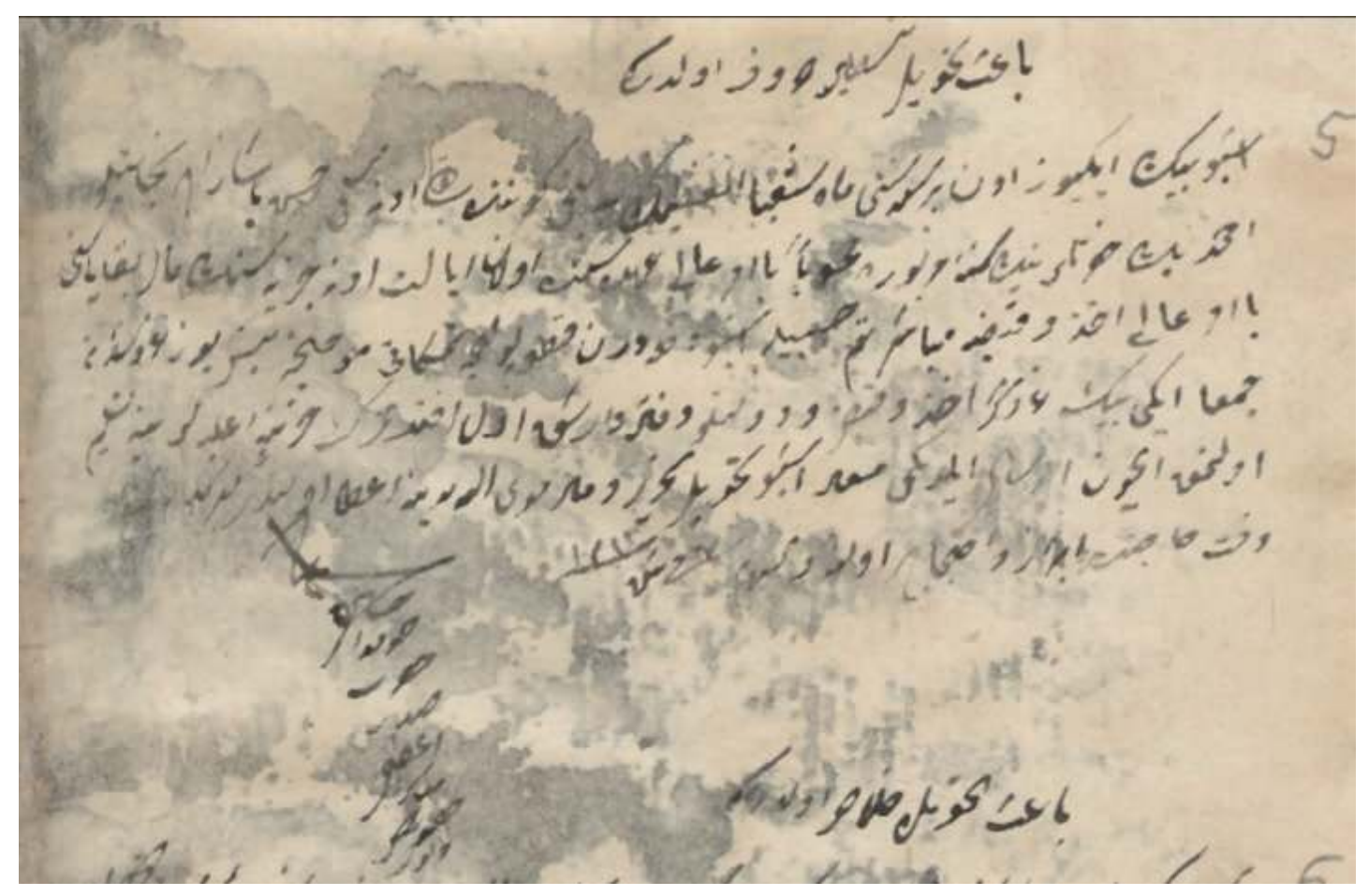

25: Adana Ş.S. 56, img. 31, sayfa 73, belge 5 


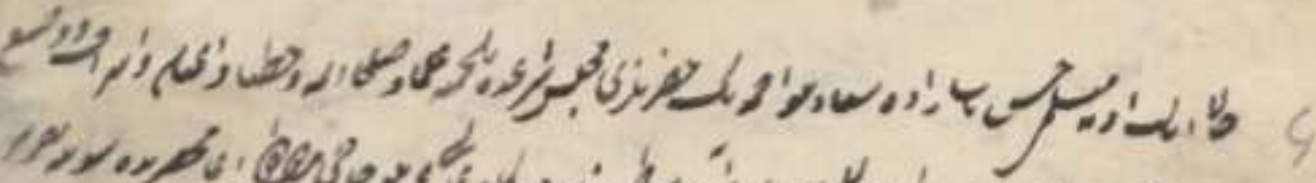
(2)

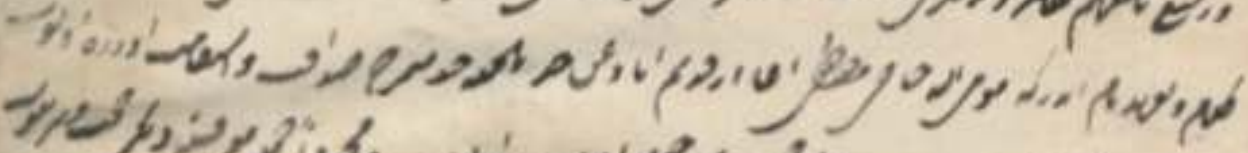

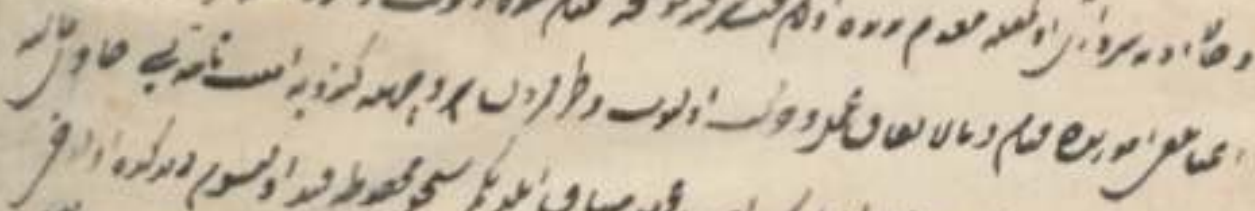

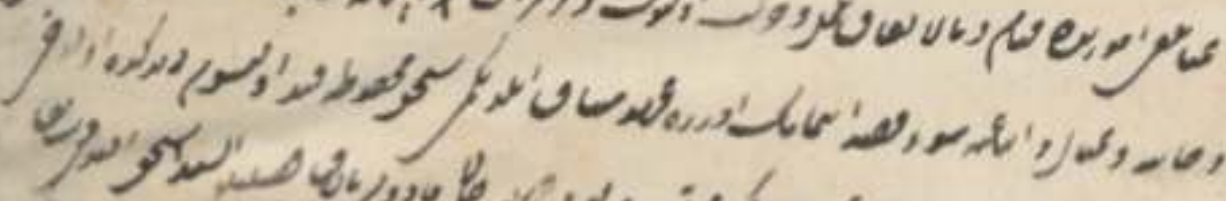
ق

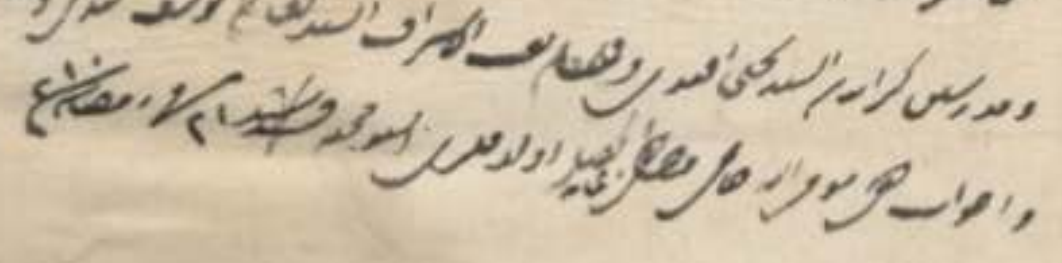

26: Adana Ş.S. 56, img. 31, sayfa 73, belge 4 


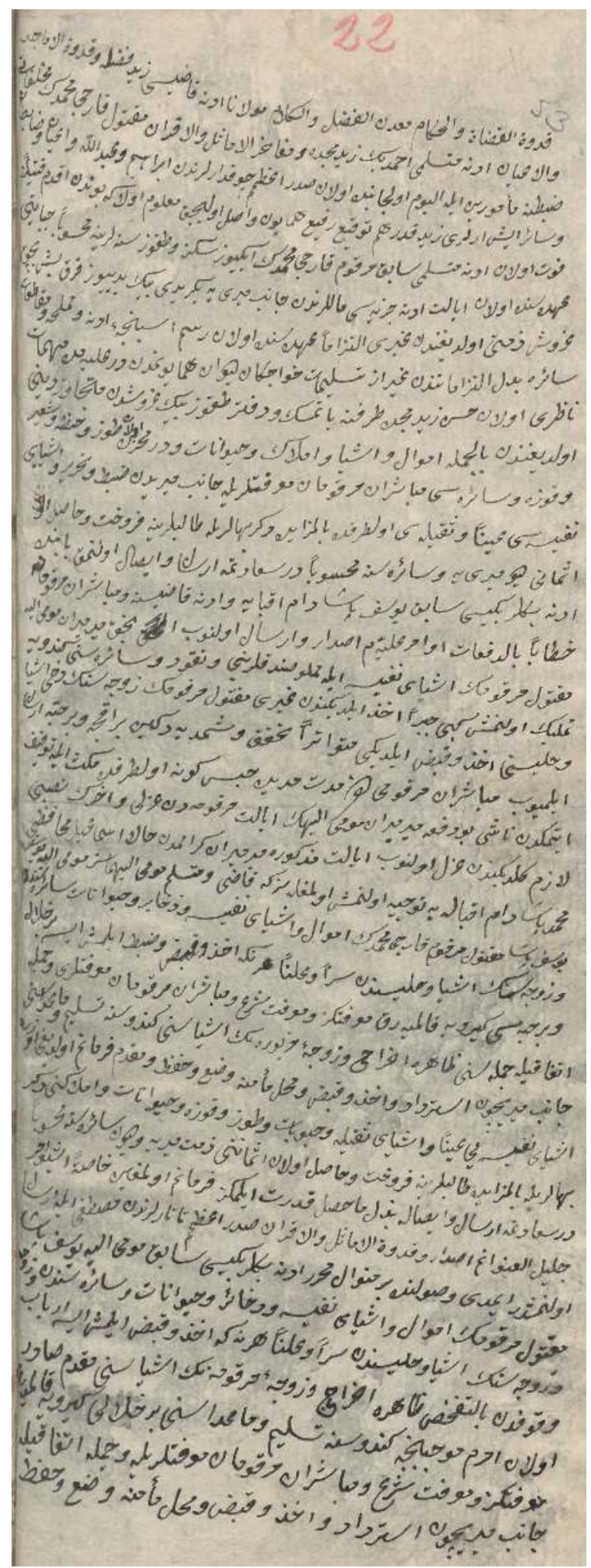

27: Adana Ş.S. 56, img. 12, sayfa 22-23, belge 53

Belgeler, Cilt: 37/Sayı: 41; 39-210 


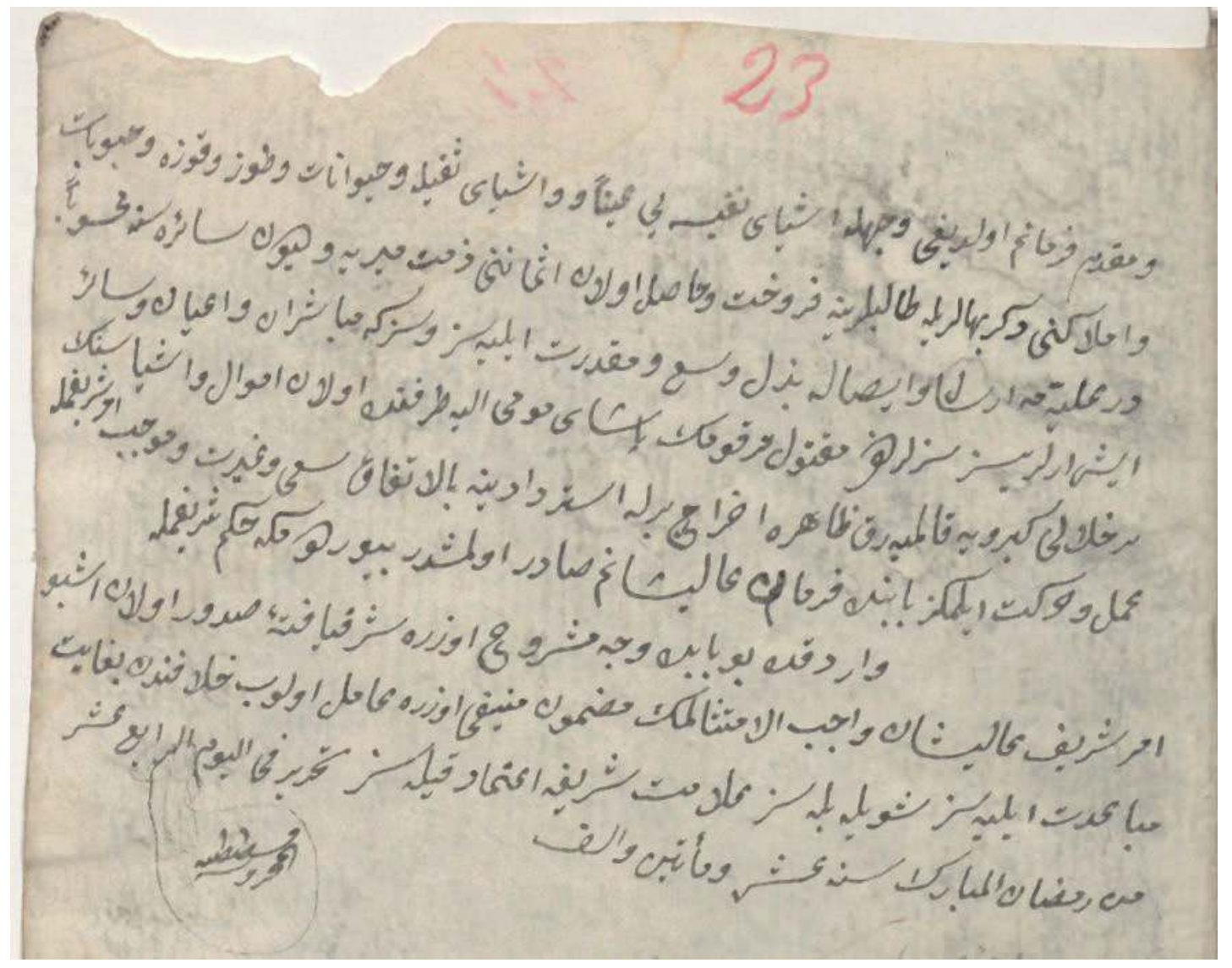

27: Adana Ş.S. 56, img. 12, sayfa 22-23, belge 53 


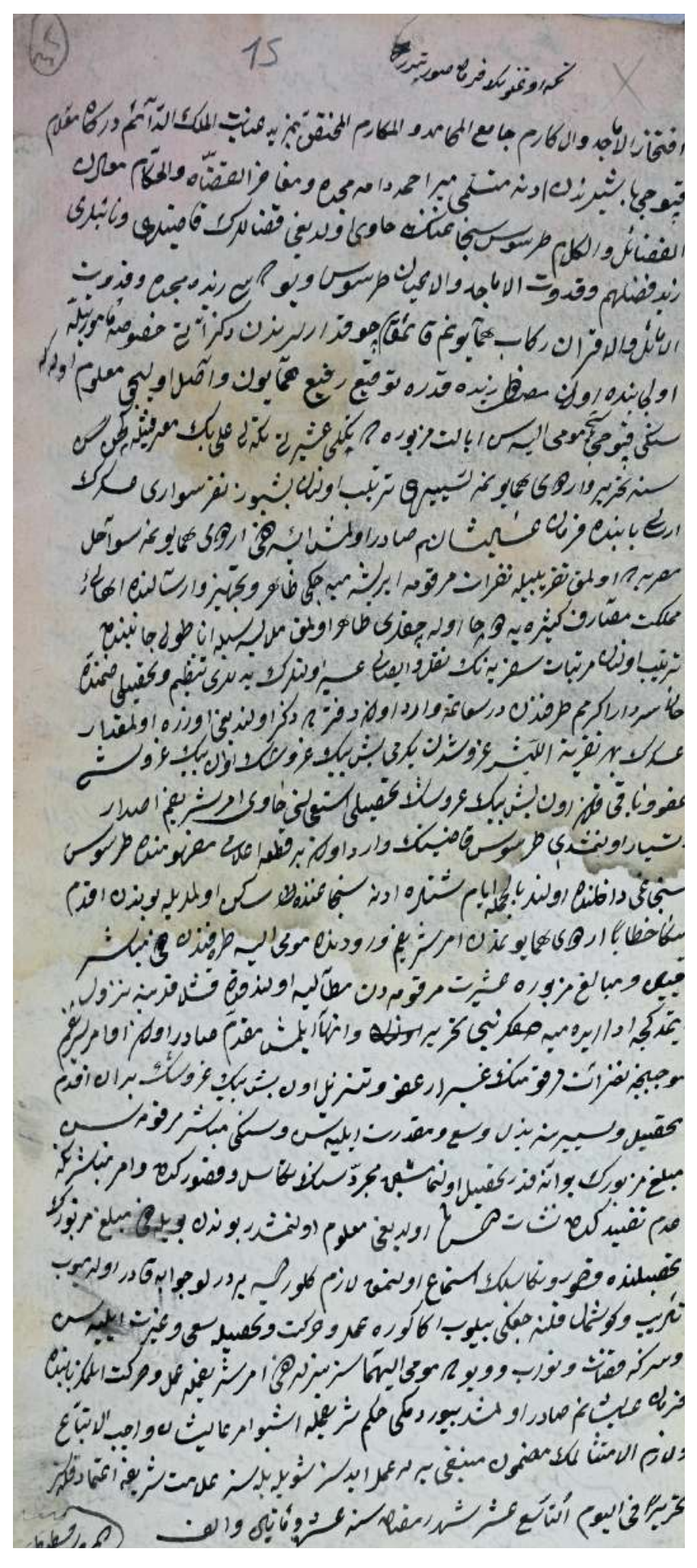

28: Adana Ş. S. 57, img. 10, sayfa 13, belge 35 


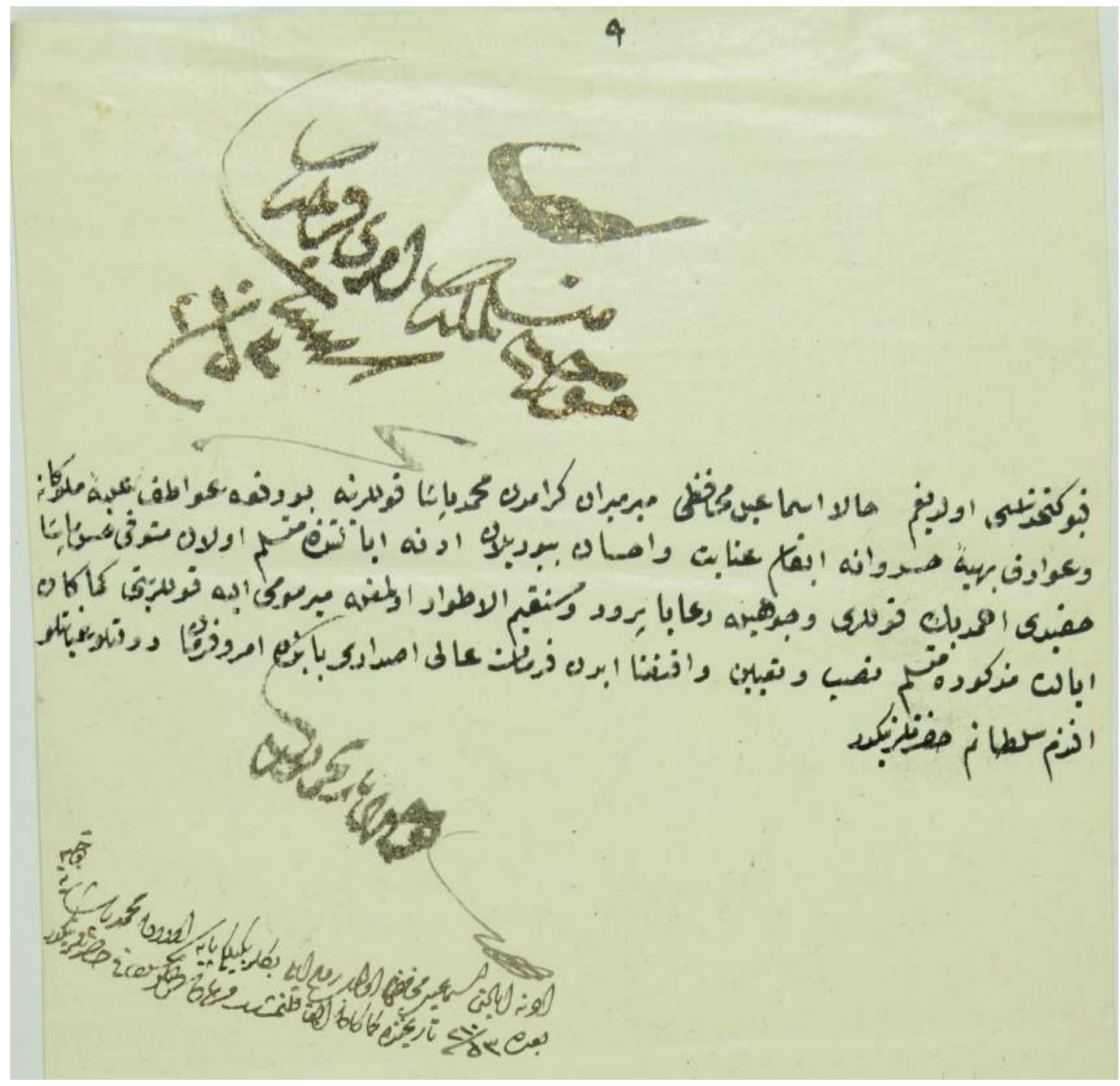

29: BOA, C. DH. 11/533 


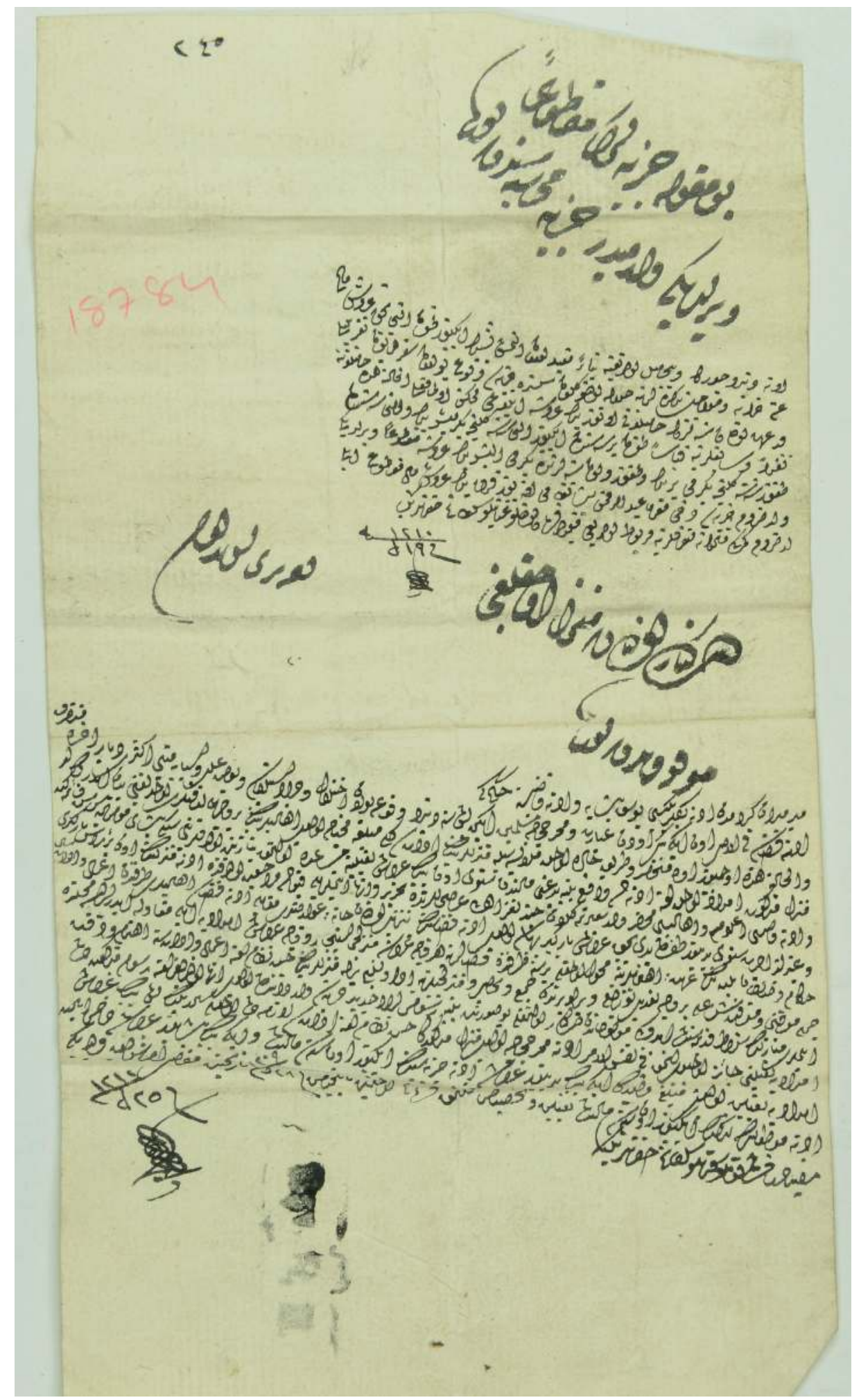

30: BOA, C. ML 462/18784-1 


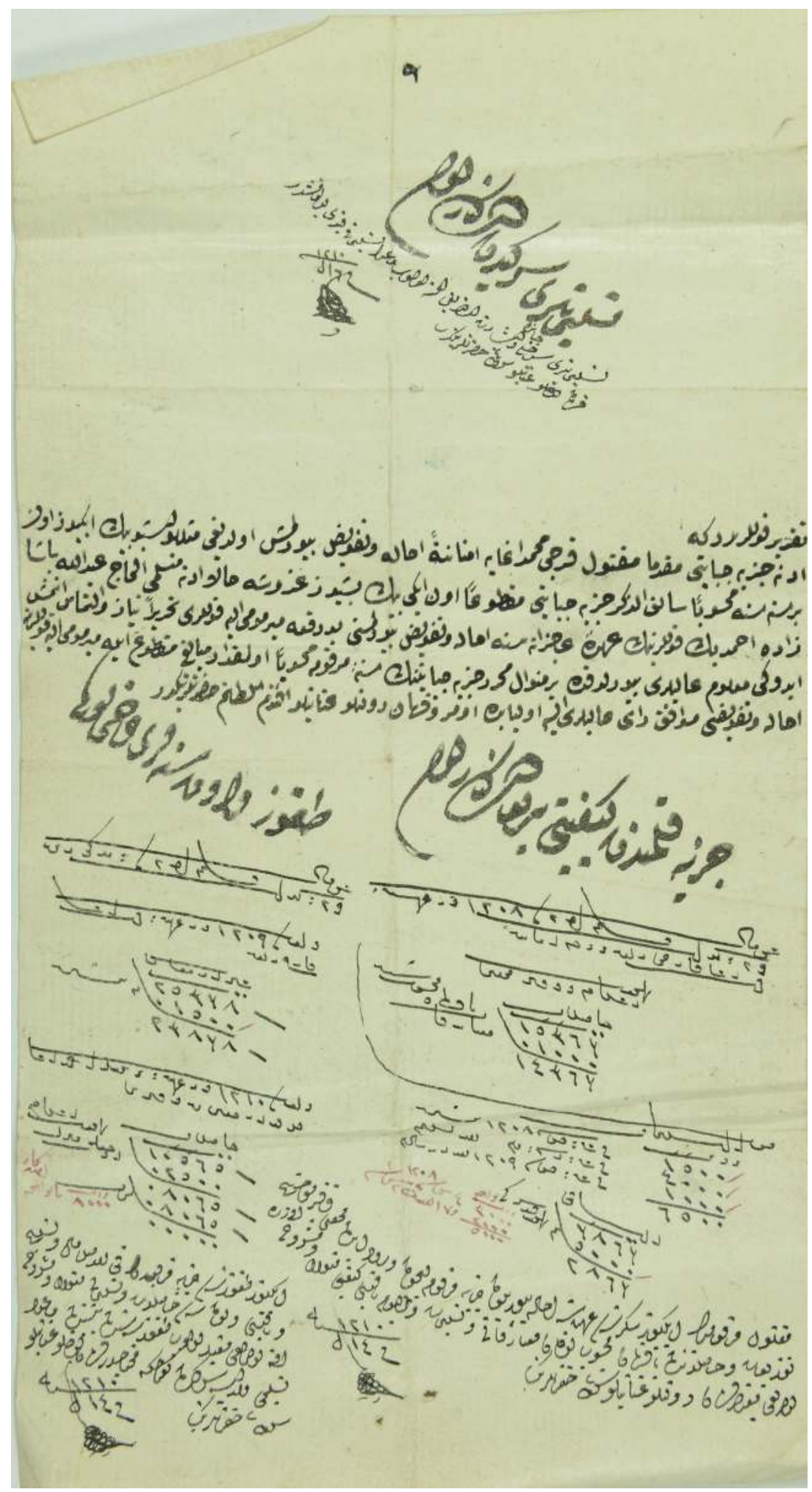

31: BOA, C. ML 462/18784-2 


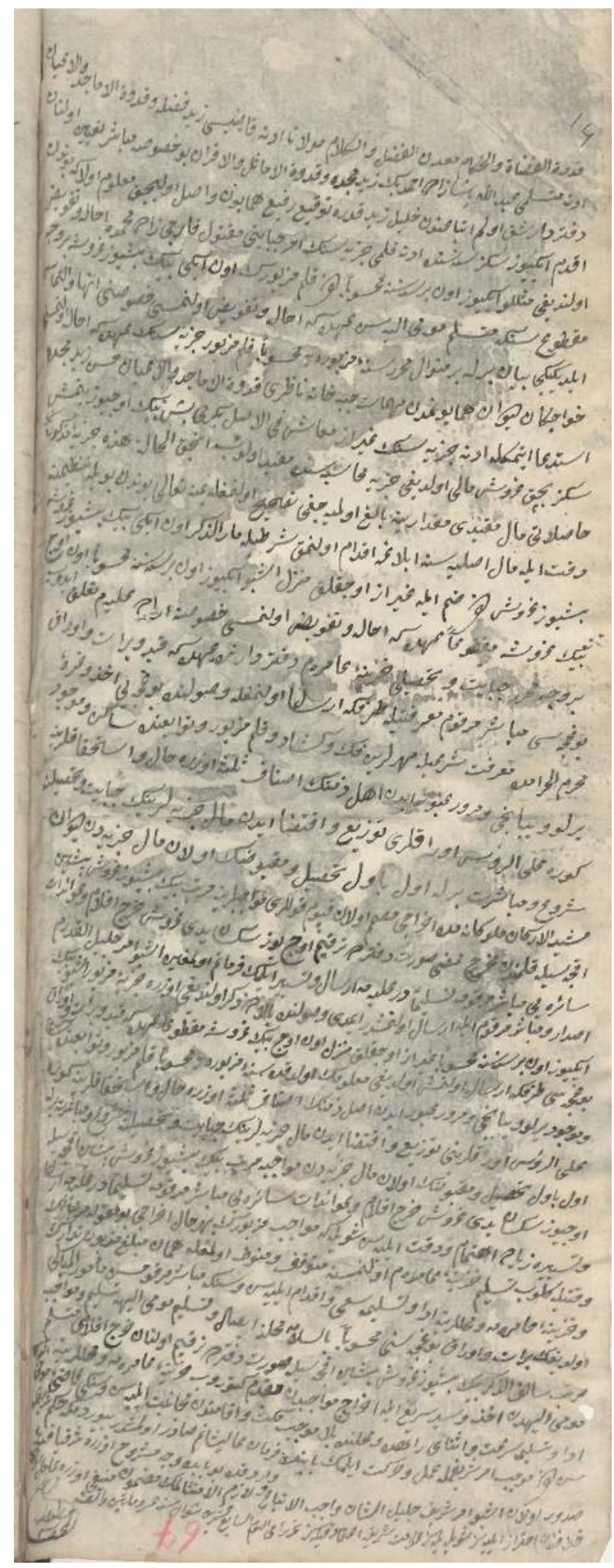

32: Adana Ş.S. 56, img. 28, sayfa 67, belge 14 


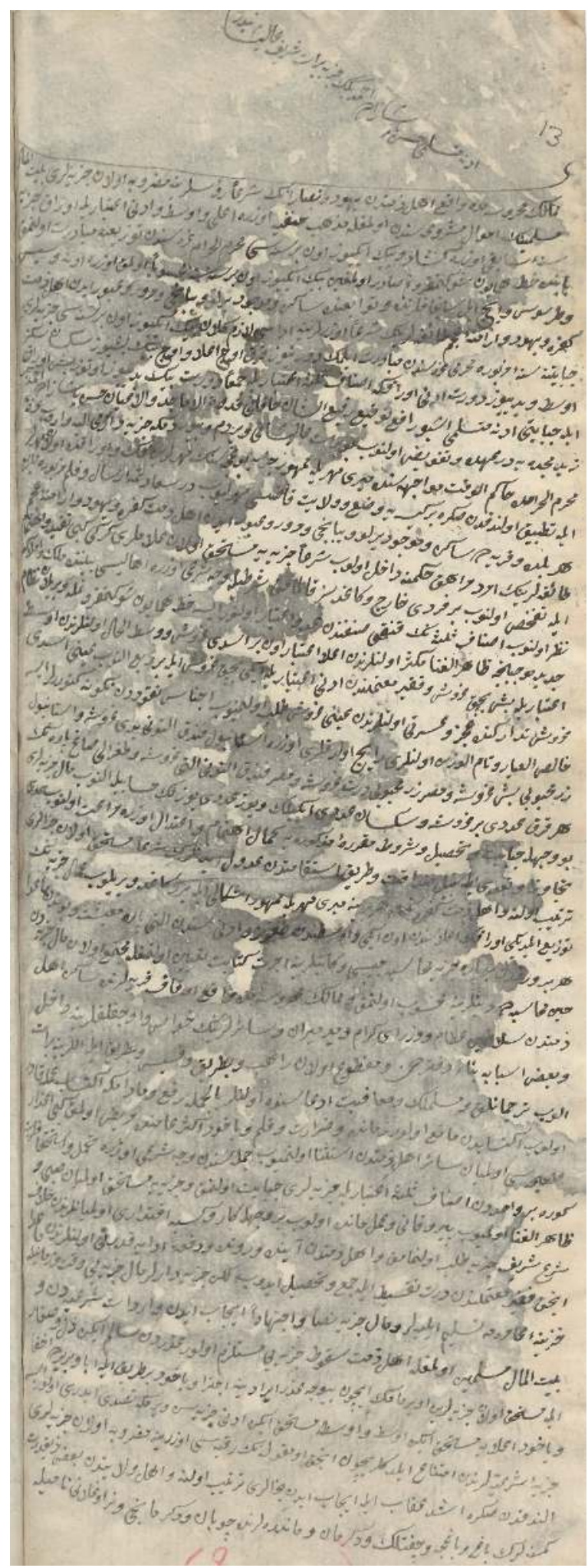

33: Adana Ş.S. 56, img. 29, sayfa 69, belge 13 


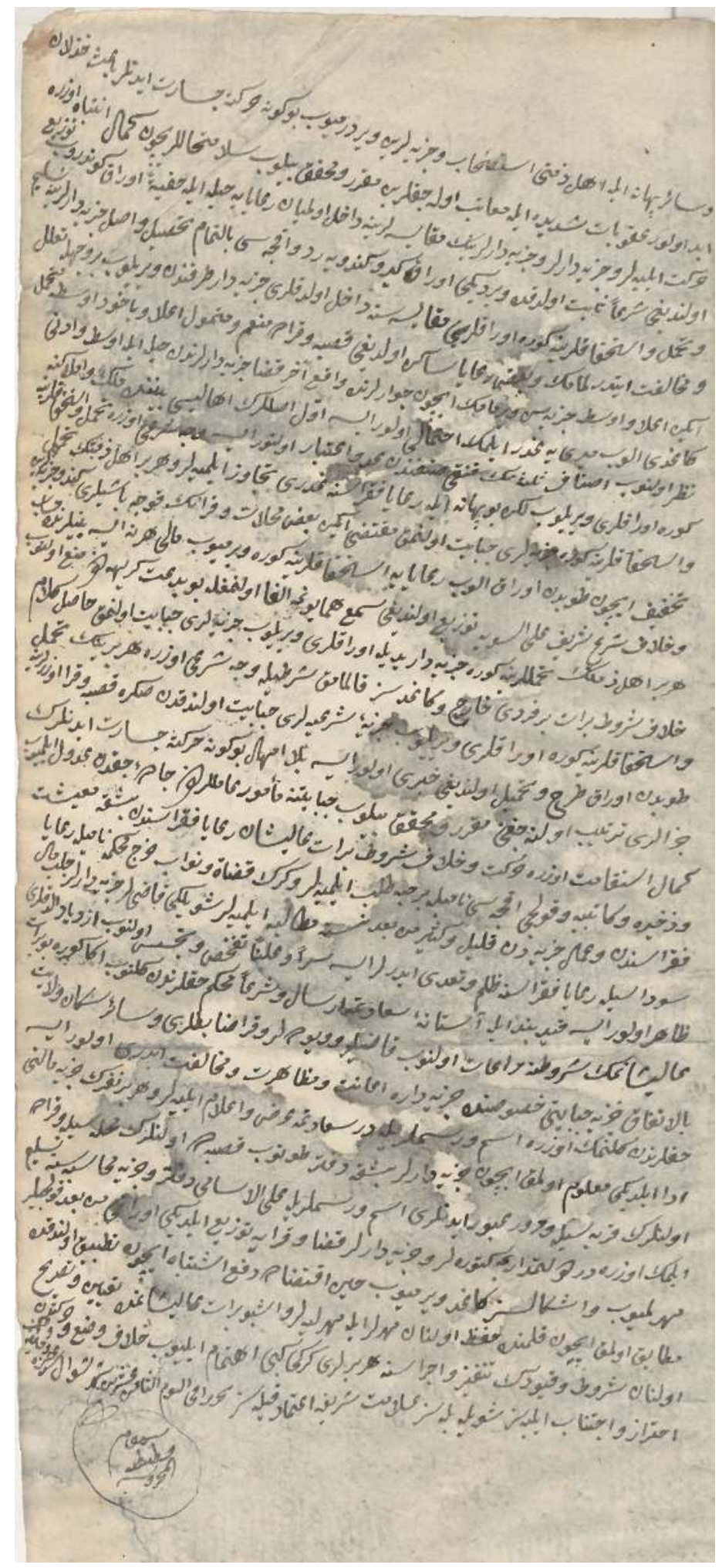

33: Adana Ş.S. 56, img. 29, sayfa 69, belge 13 


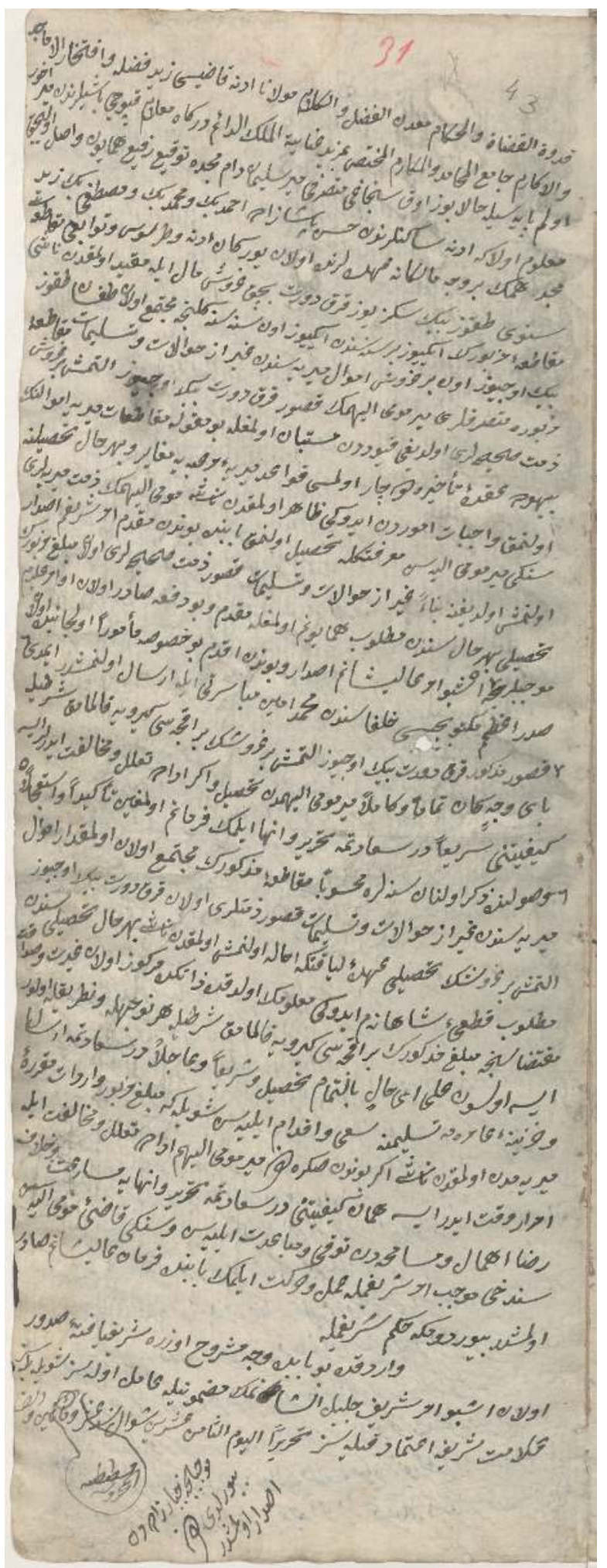

34: Adana Ş.S. 56, img. 16, sayfa 31, belge 43 




35: BOA, C. ML 462/18784-3 


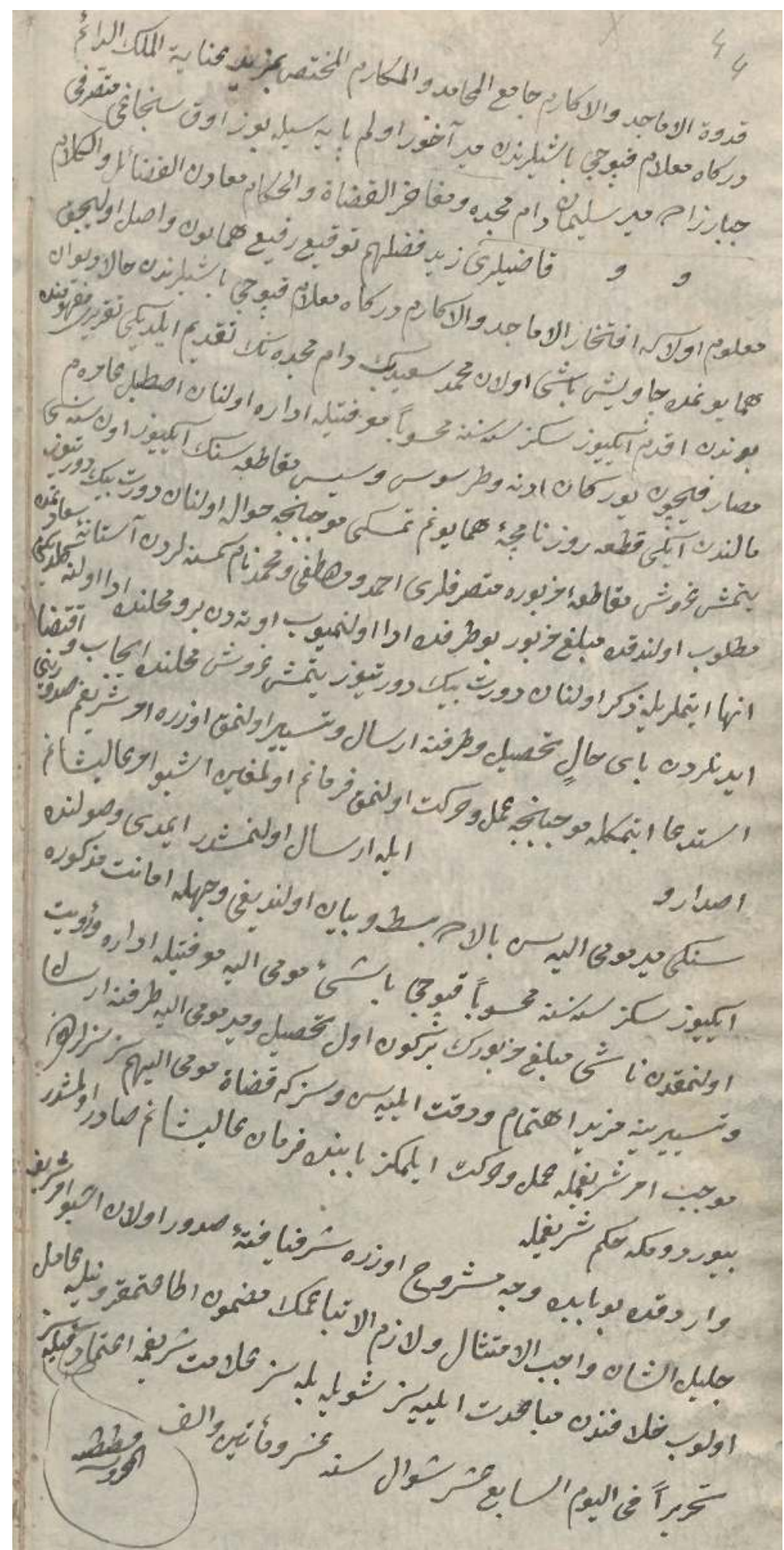

36: Adana Ş.S. 56, img. 16, sayfa 30, belge 44 


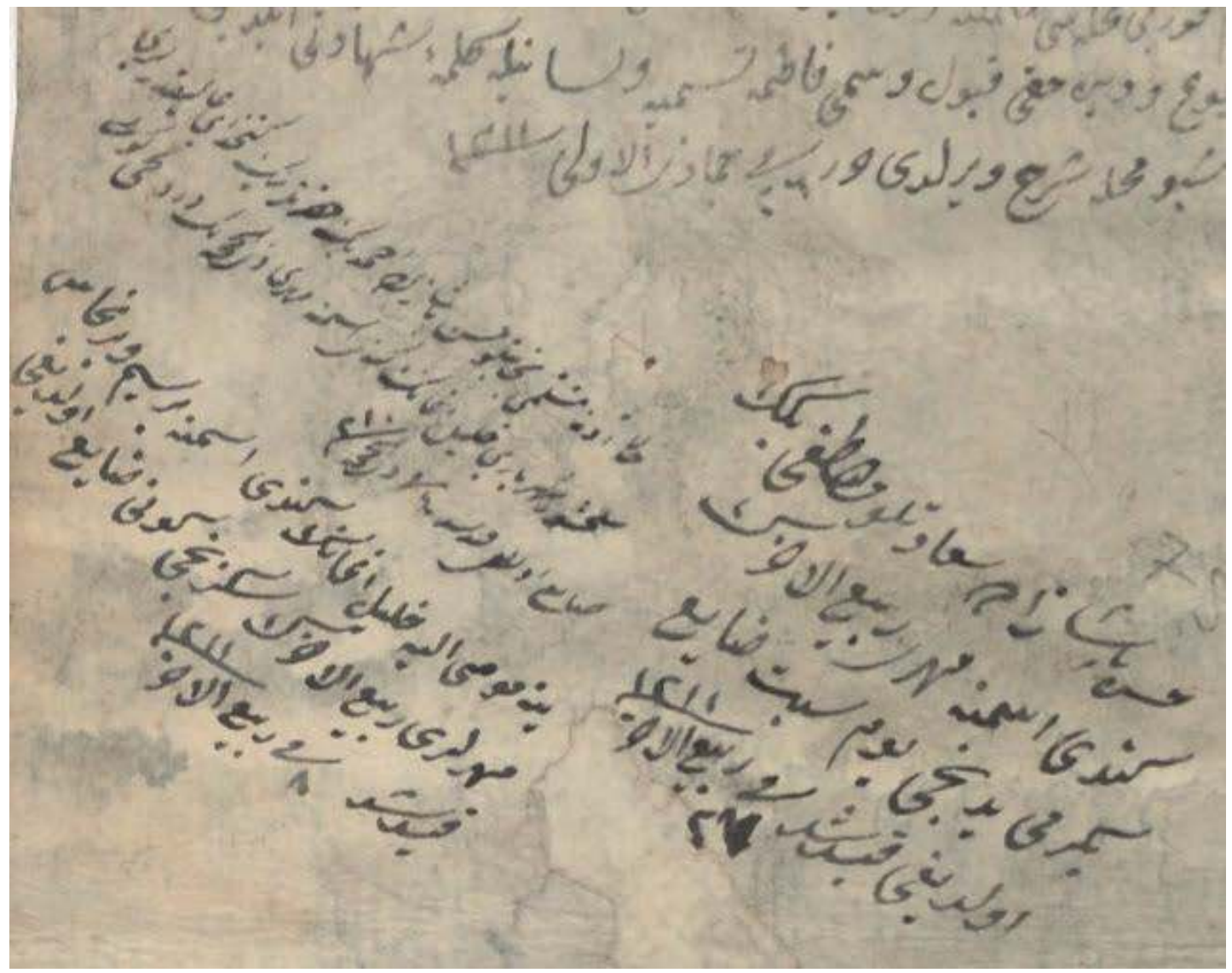

37: Adana Ş.S. 56, img. 01, sayfa 01, belge 78-b 


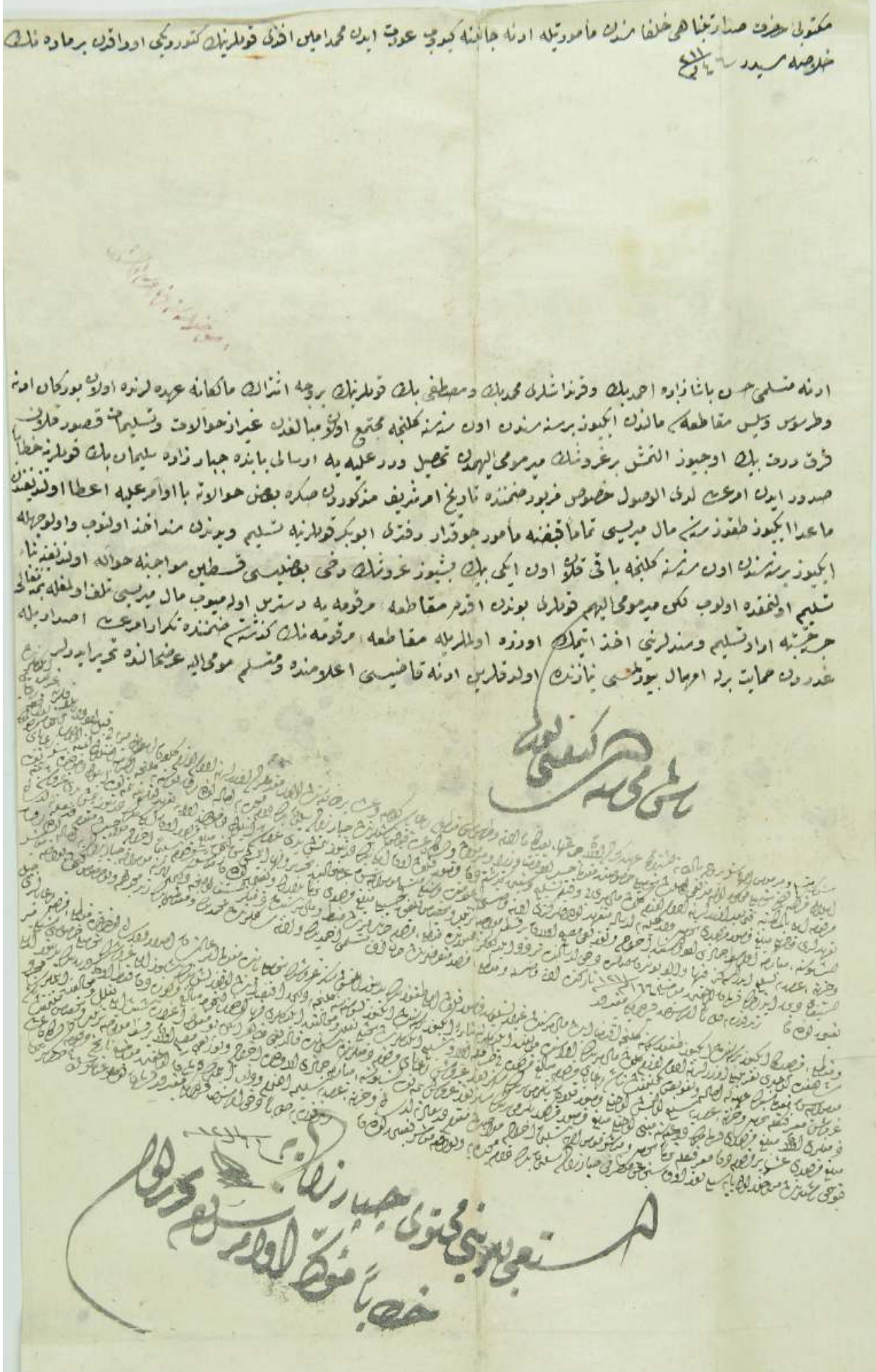

38: BOA, C. ML 781/31892 


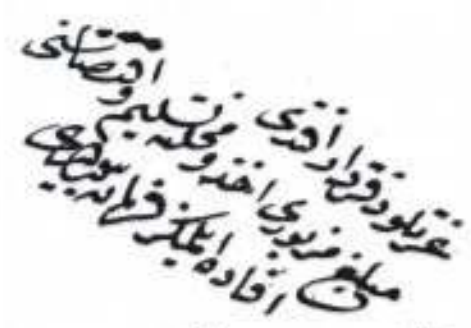

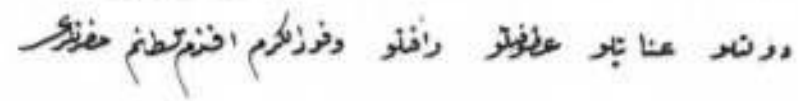

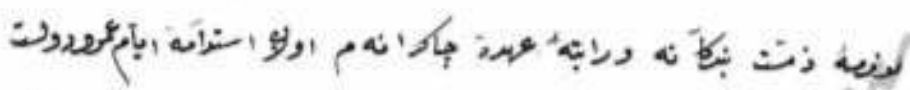

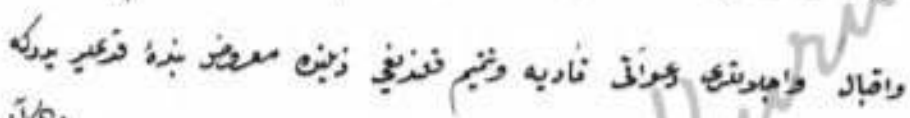
幽

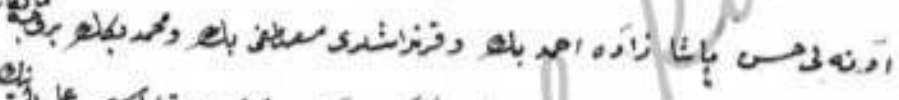

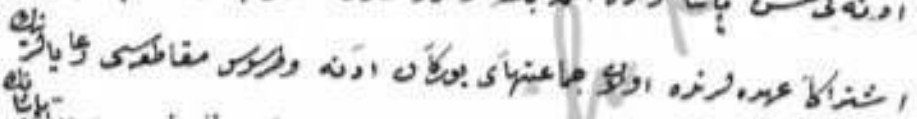
选 f:

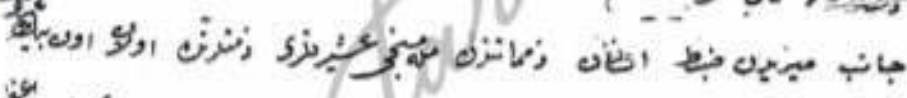

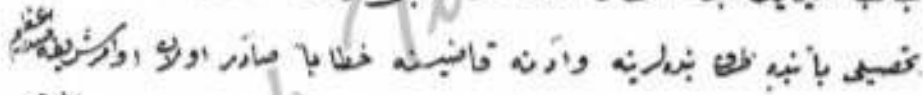

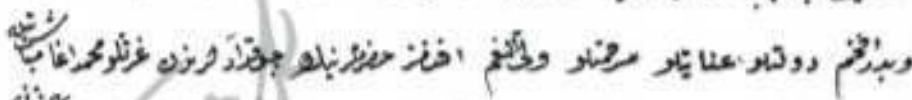

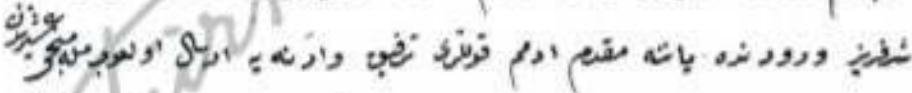

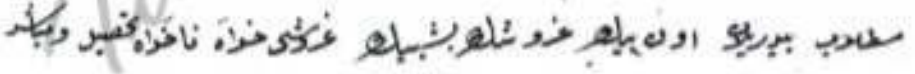

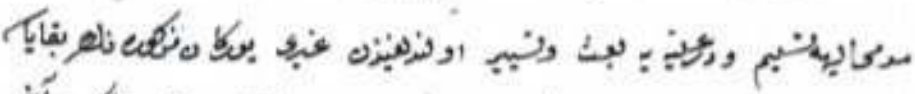

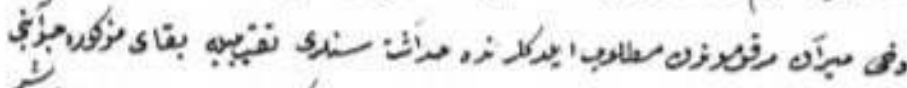

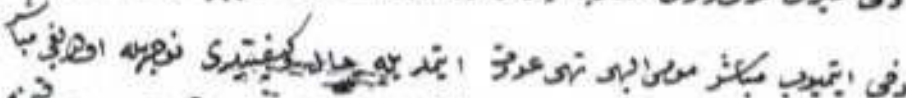

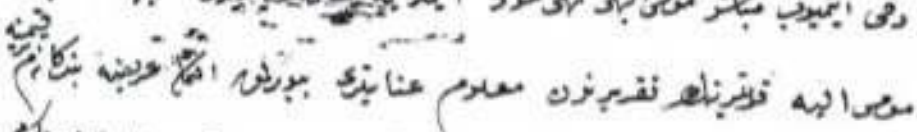

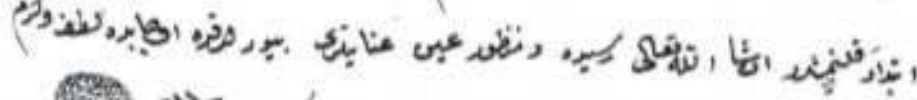

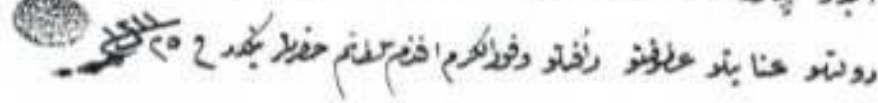

39: BOA, C. Dahiliye 17063-B 


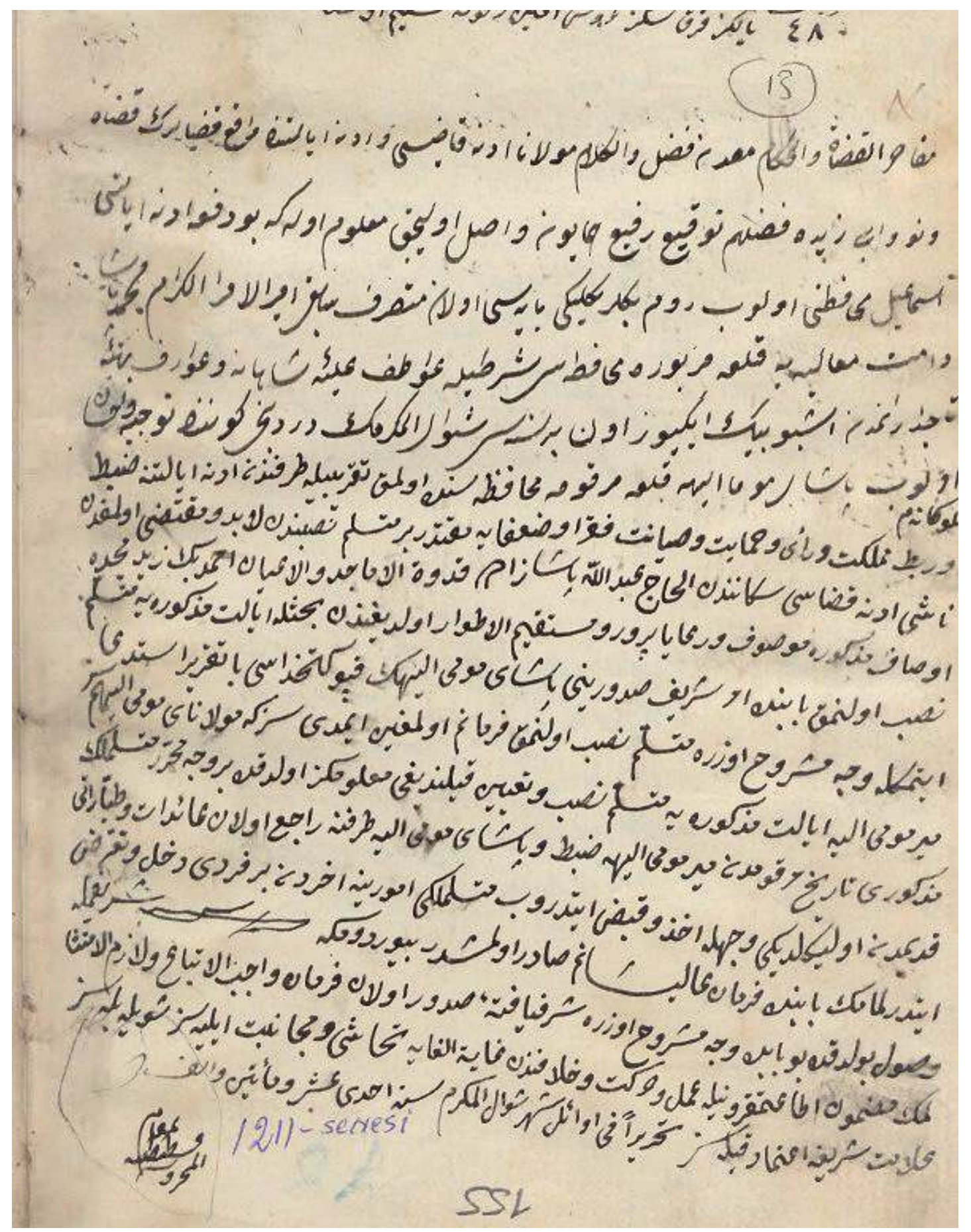

40: Adana Ş.S. 55, img. 78, sayfa 153 belge 13 


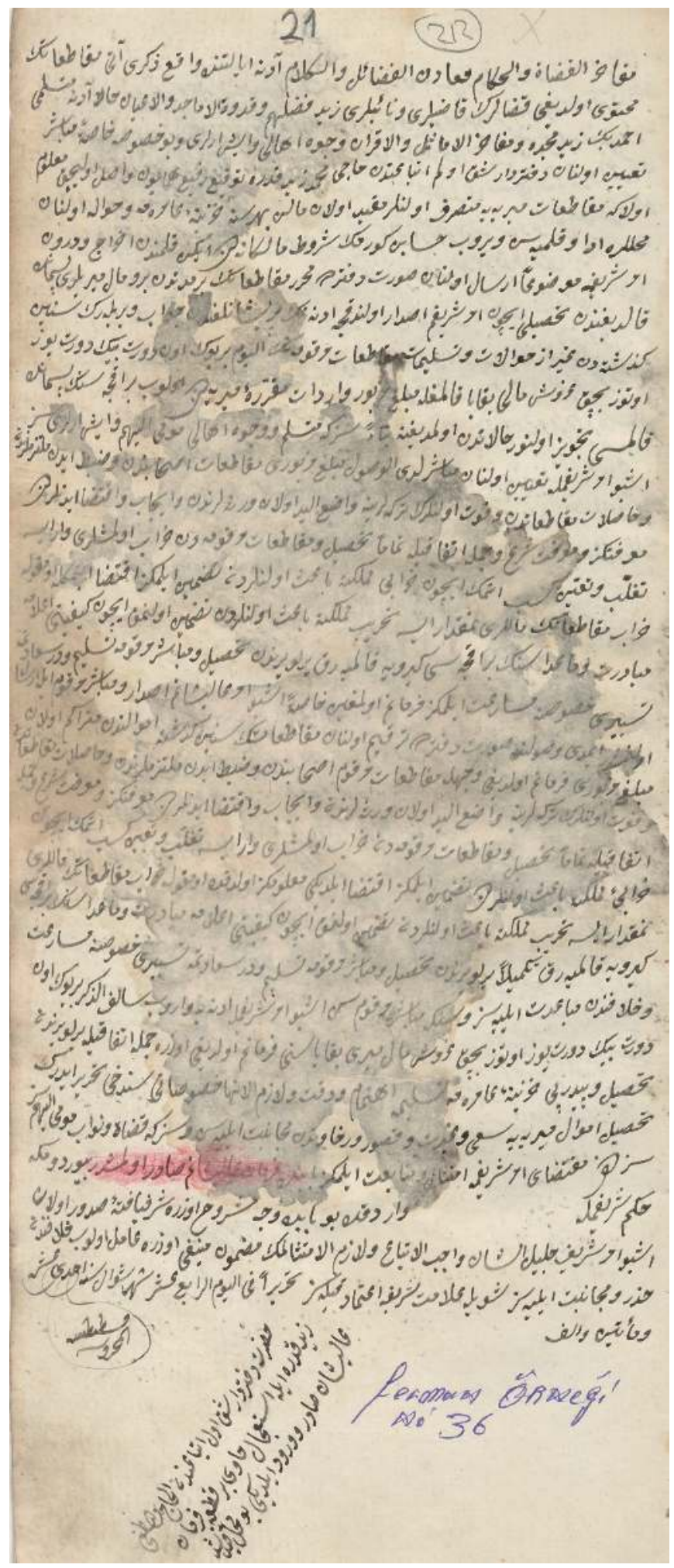

41: Adana Ş.S. 55, img. 11, sayfa 21, belge 212 


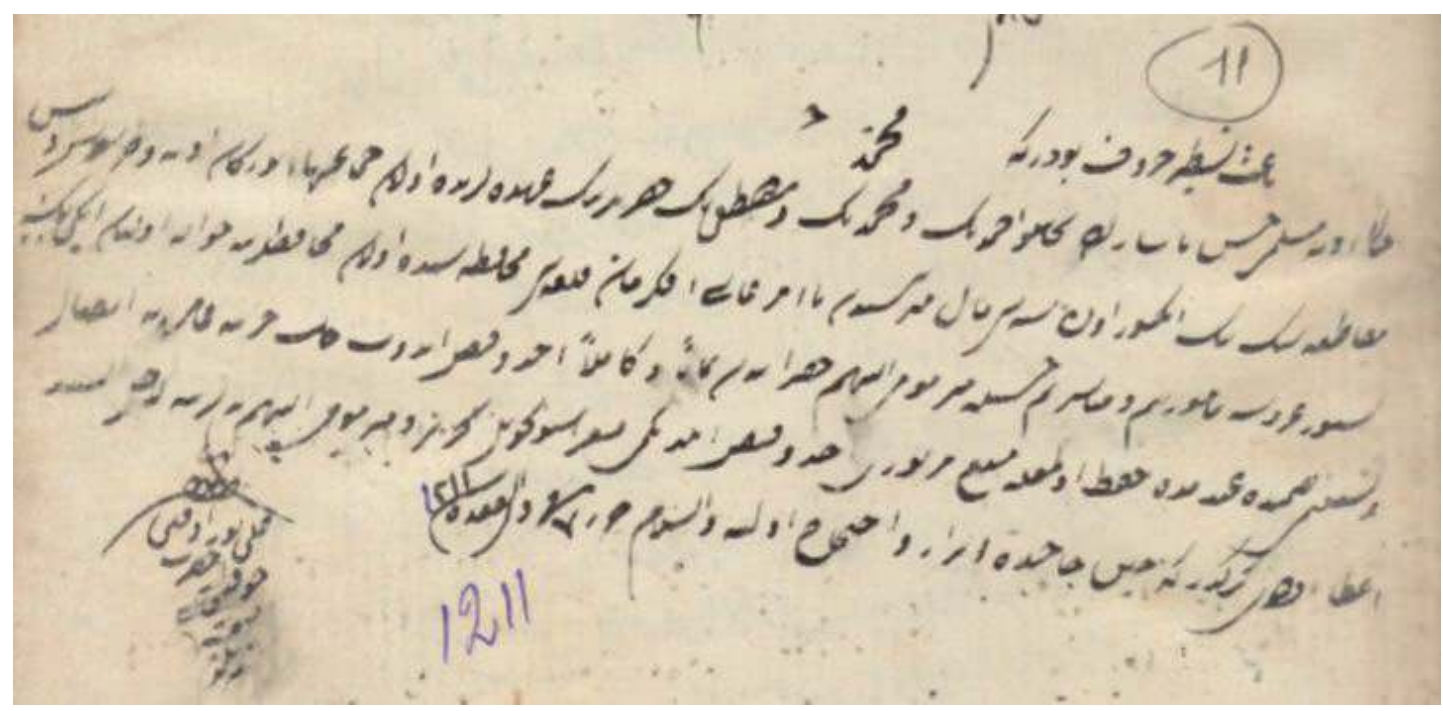

42: Adana Ş.S. 55, img. 79, sayfa 154, belge 11 


\section{2}

(211)

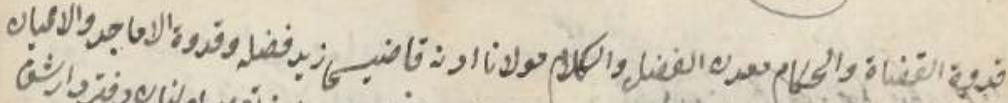

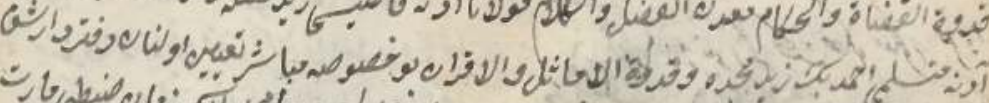

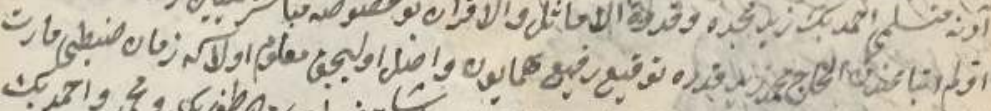

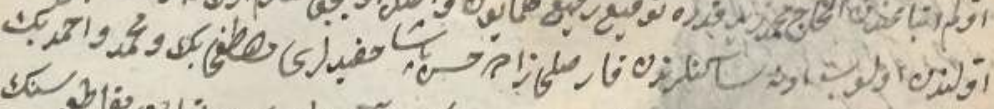
so.

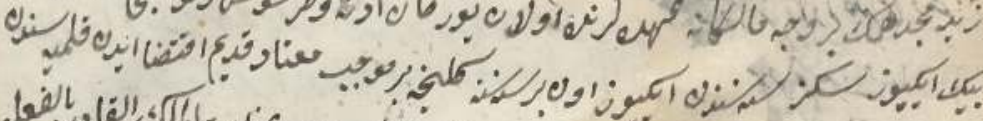

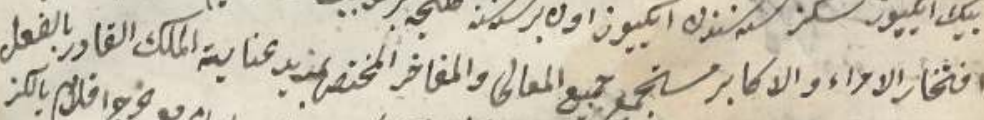
. .

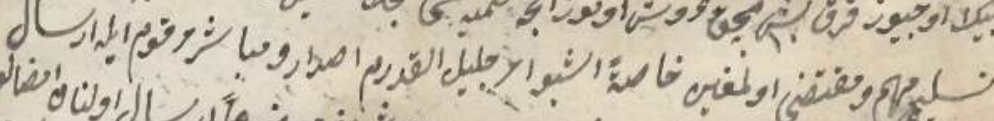

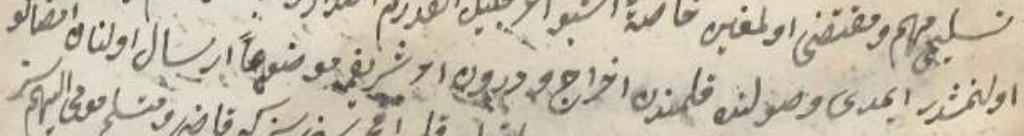

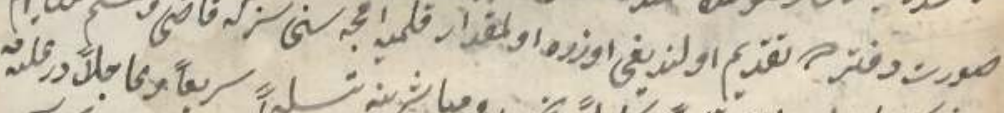
Sز

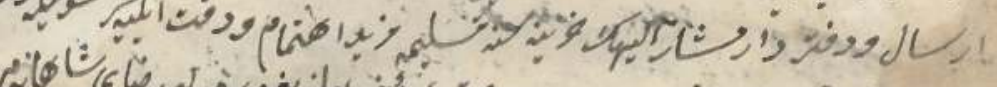

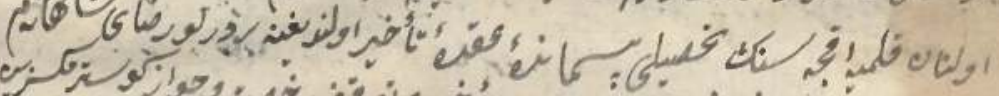

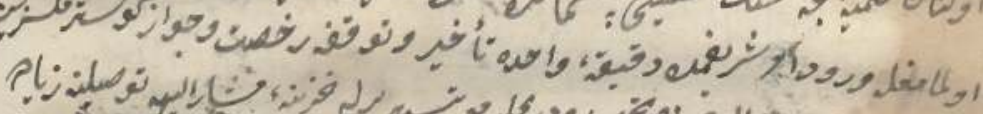

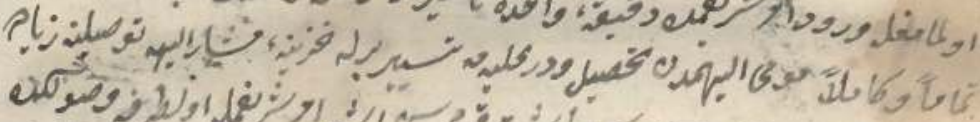
OF نون Huelc tive s.

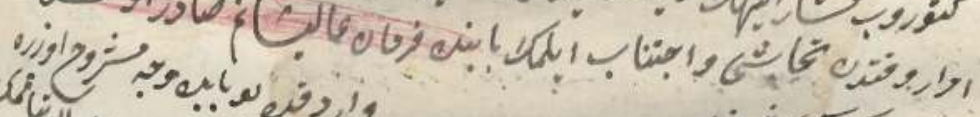

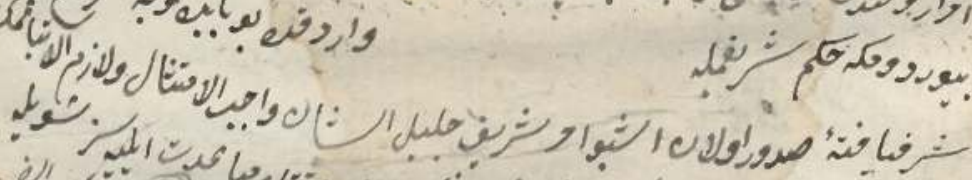

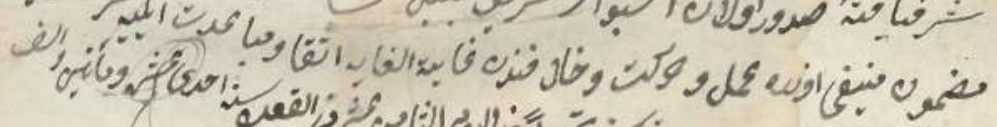

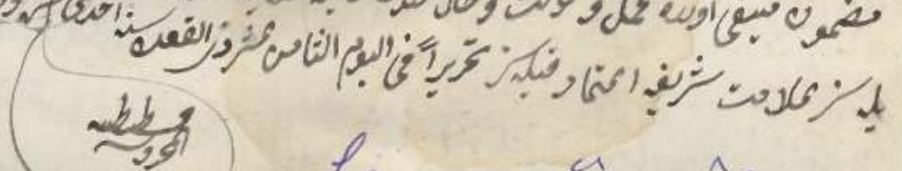
Lenmad expreo?

43: Adana Ş.S. 55, img. 12, sayfa 22, belge 211 


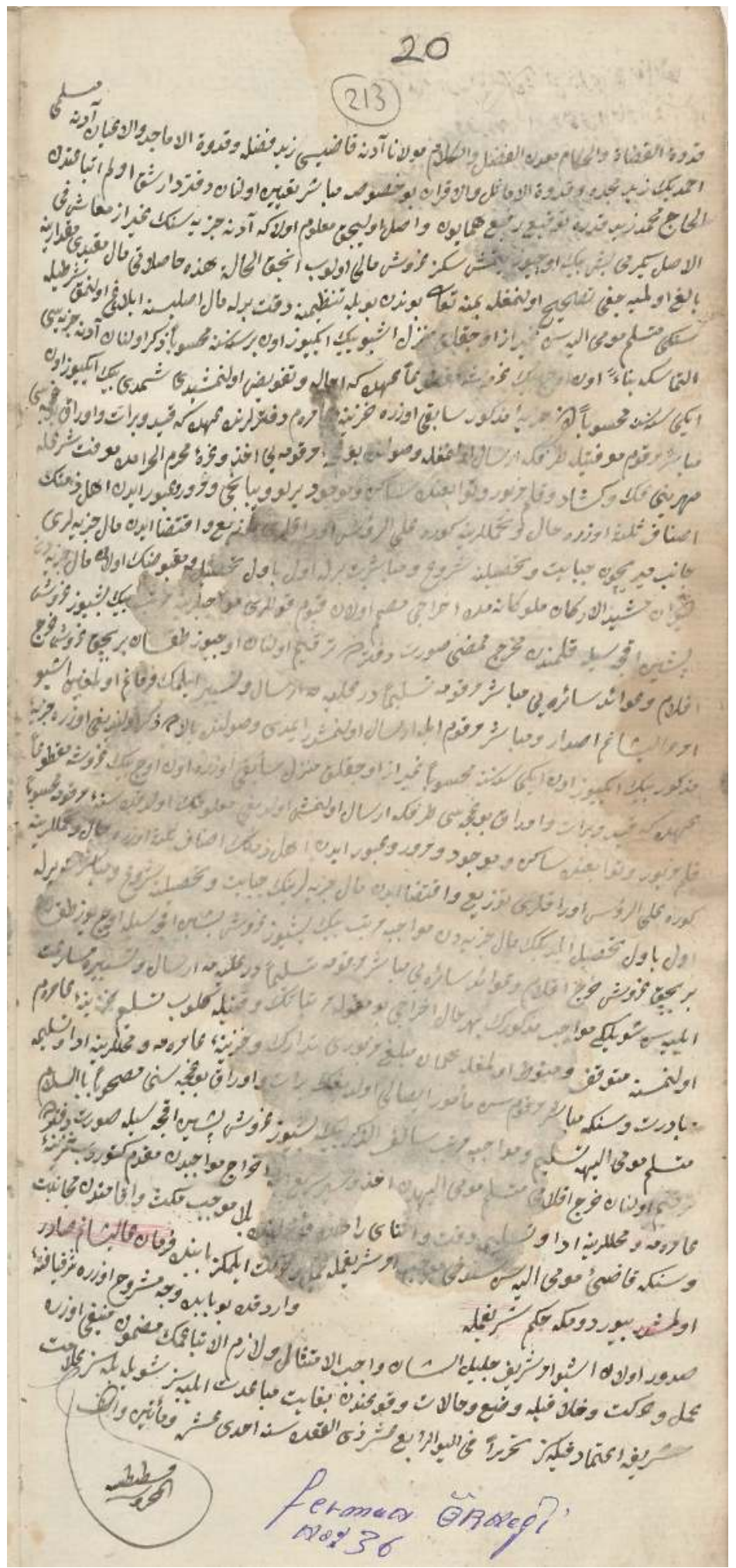

44: Adana Ş.S. 55, img. 11, sayfa 20, belge 213 


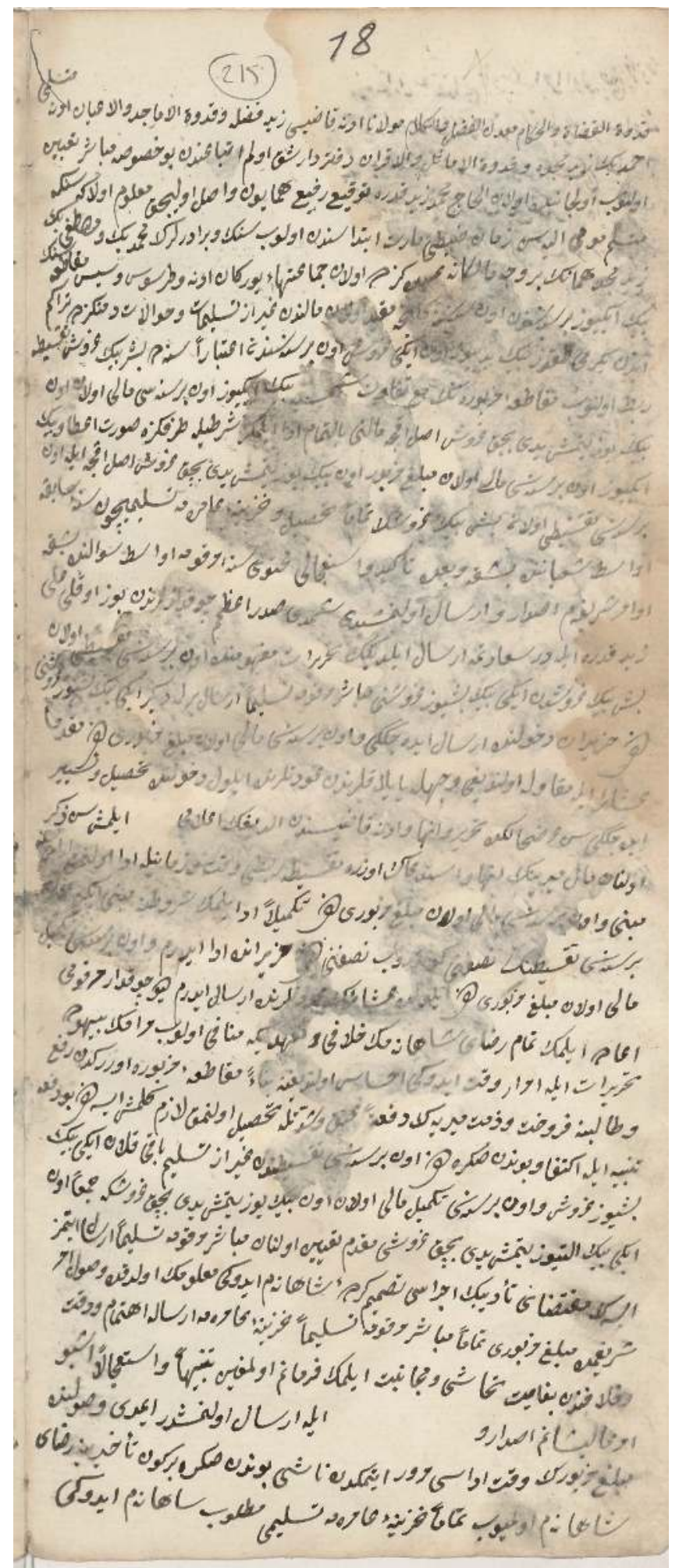

45: Adana Ş.S. 55, img. 10, sayfa 18, belge 215 


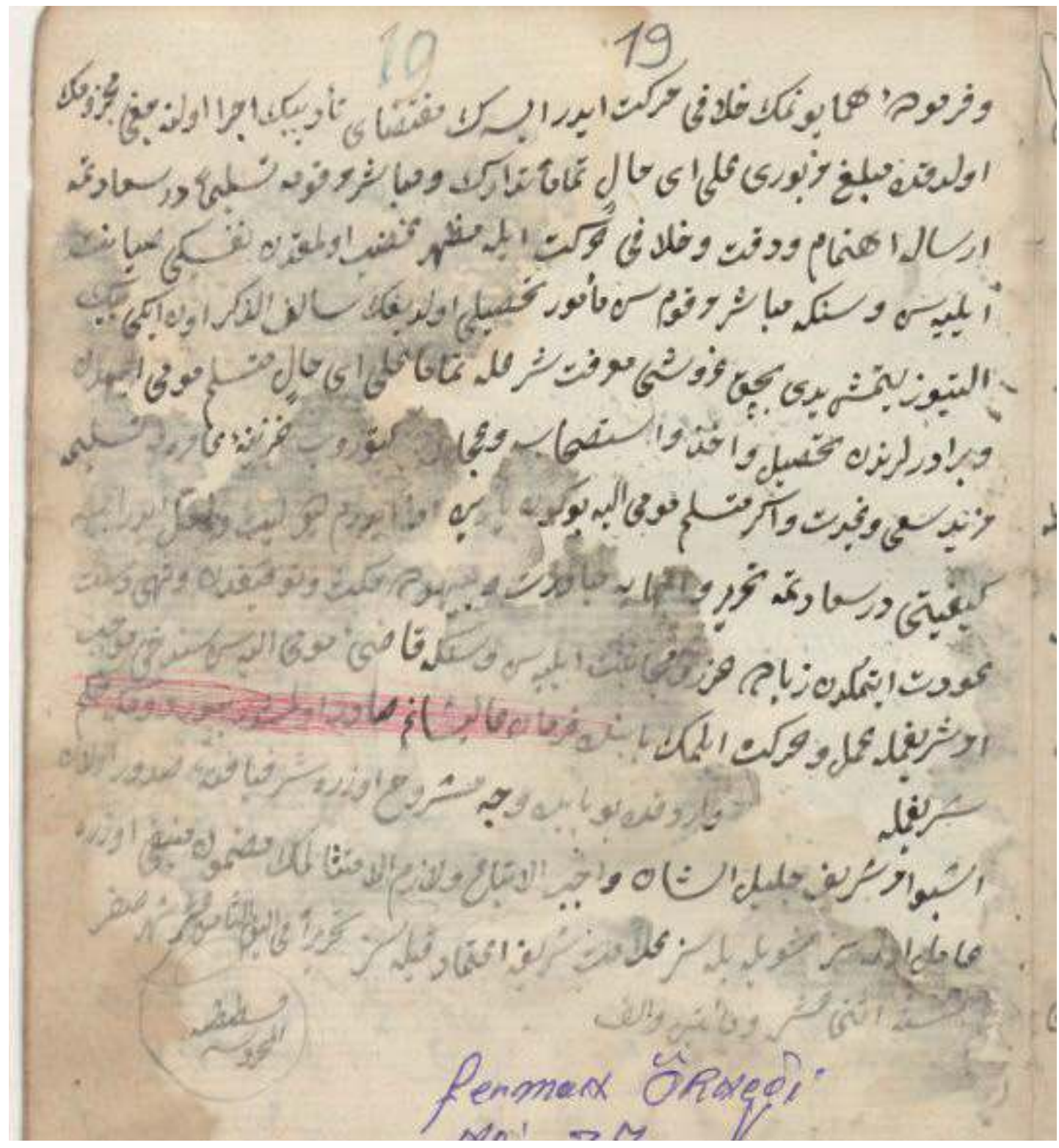

45: Adana Ş.S. 55, img. 10, sayfa 18, belge 215 


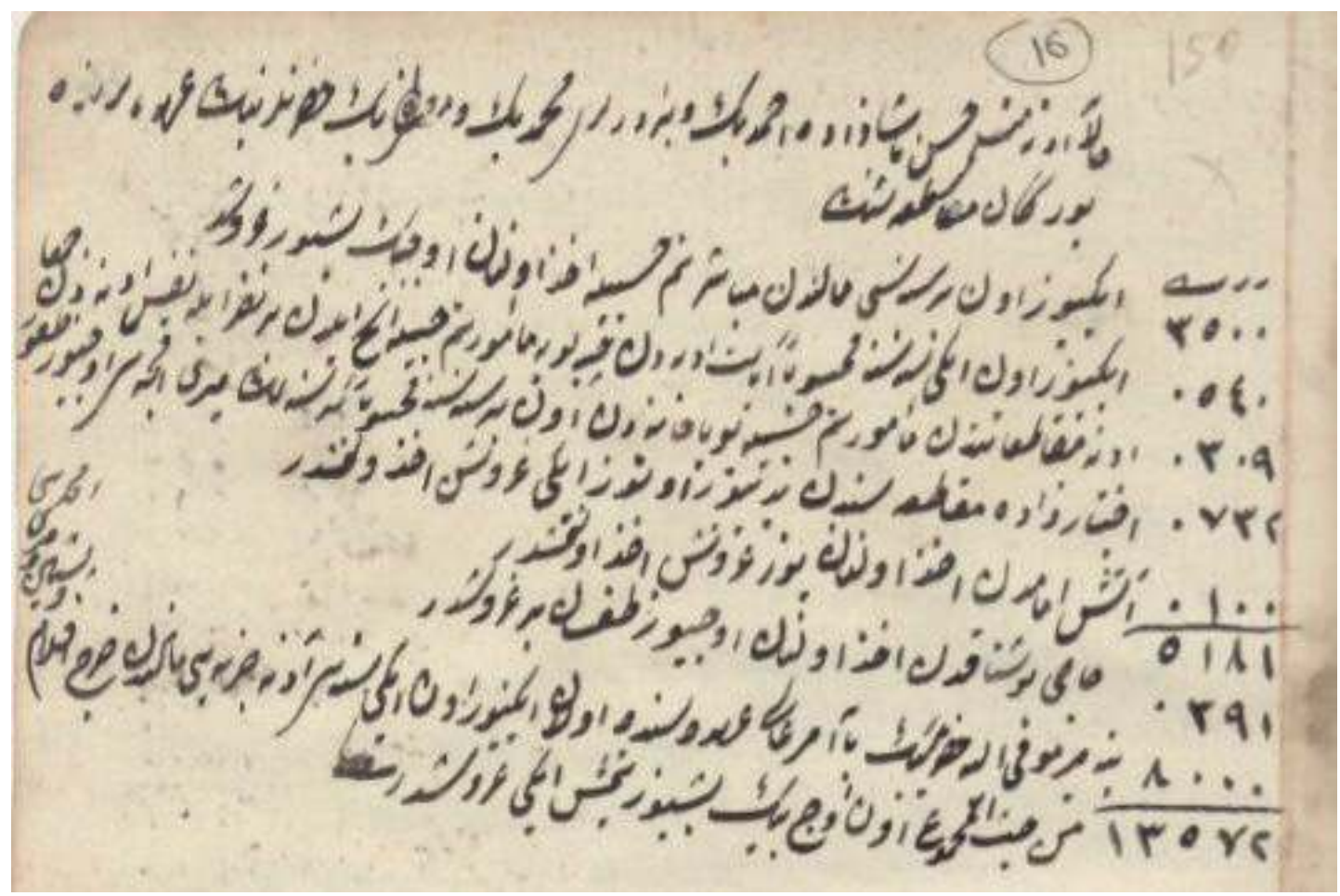

46: Adana Ş.S. 55, img. 77, sayfa 152, belge 16 


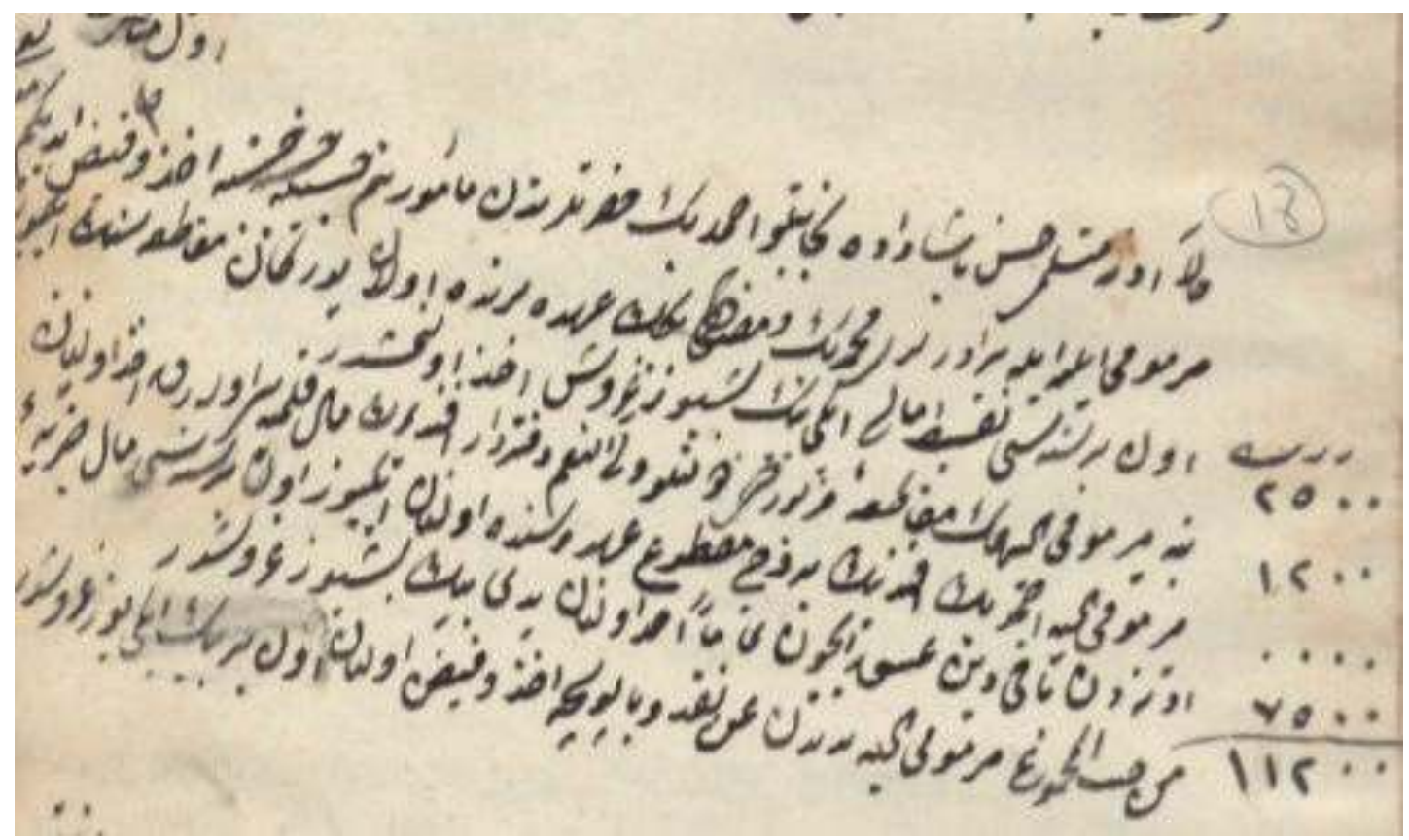

47: Adana Ş.S. 55, img. 78, sayfa 152, belge 18 


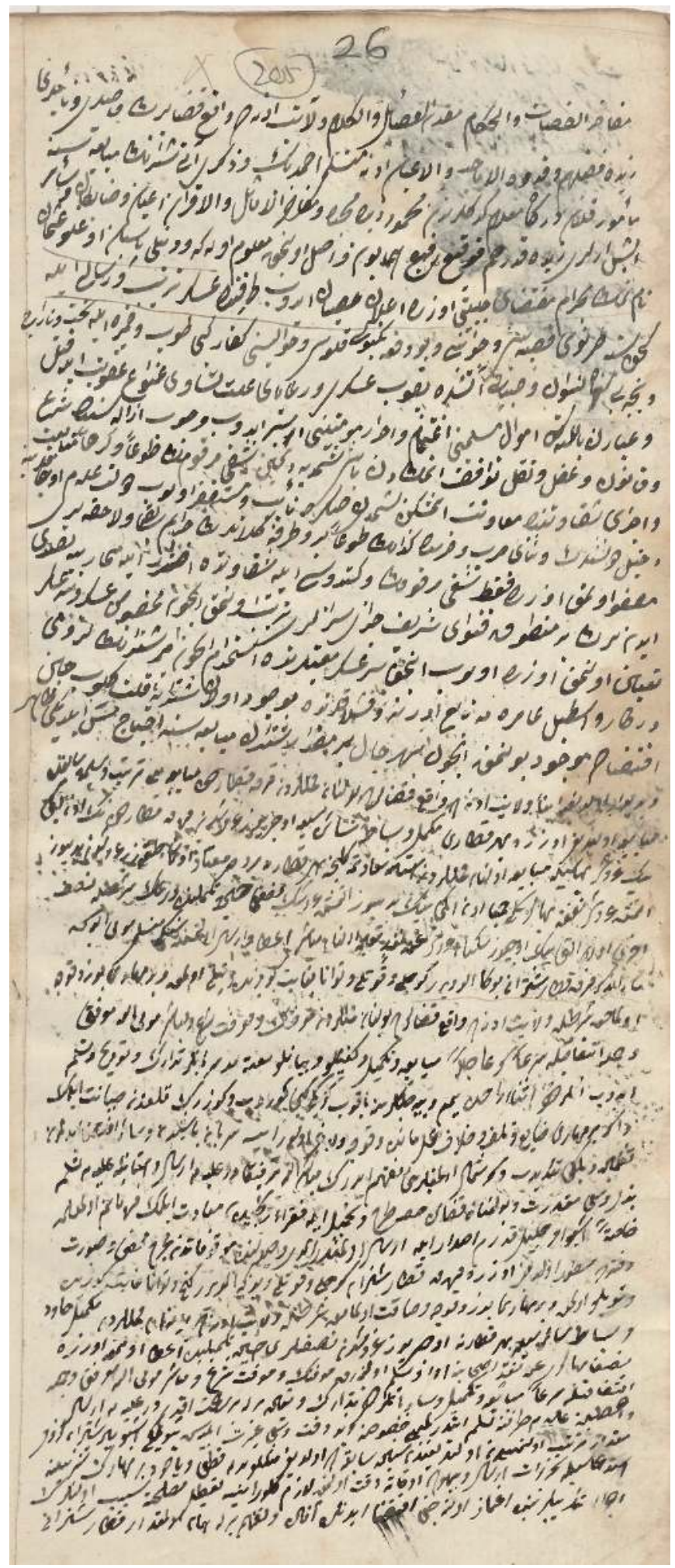

48: Adana Ş.S. 55, img. 14, sayfa 26-27, belge 205 


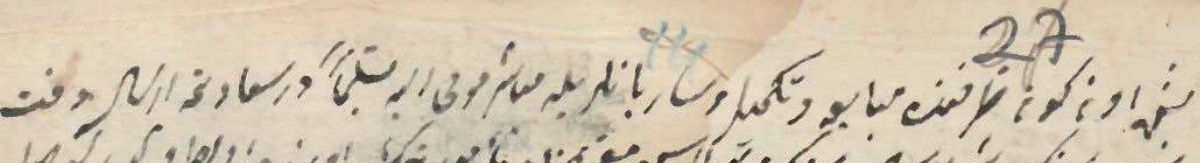

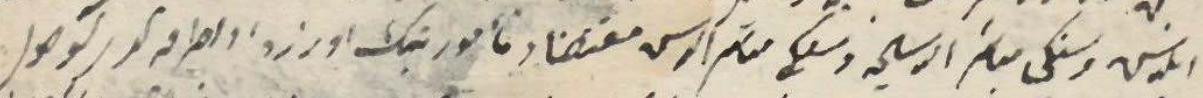

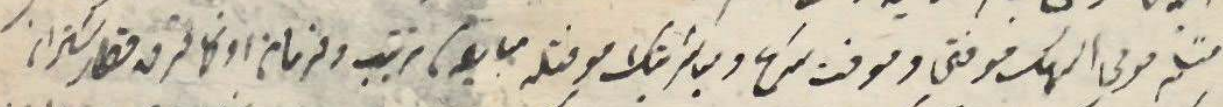
79.

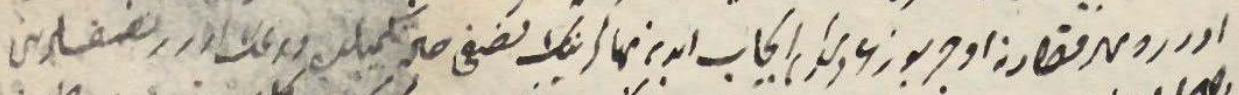

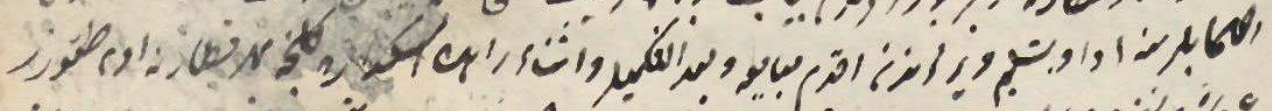

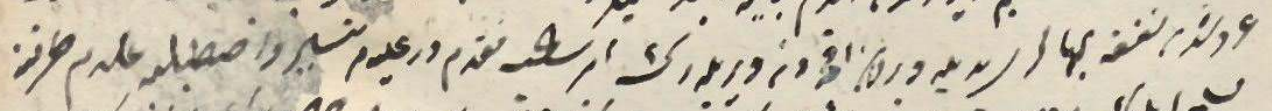
-

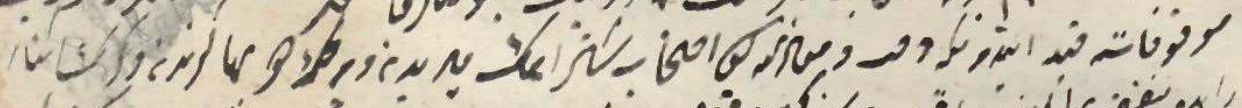
-

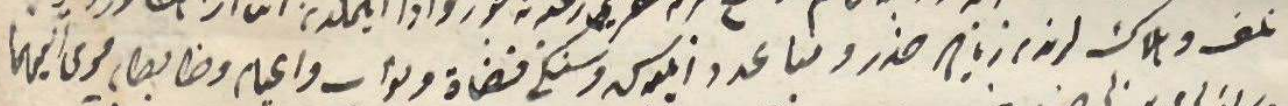
lìr

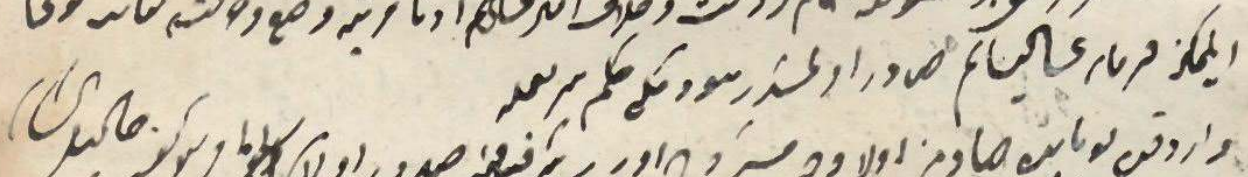

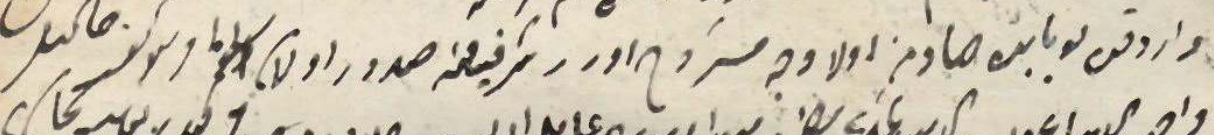
allo

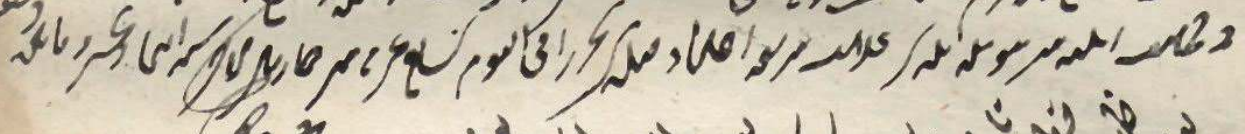

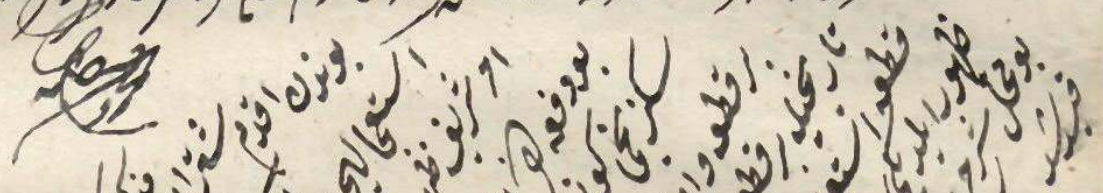
Cley, و.

48: Adana Ş.S. 55, img. 14, sayfa 26-27, belge 205 


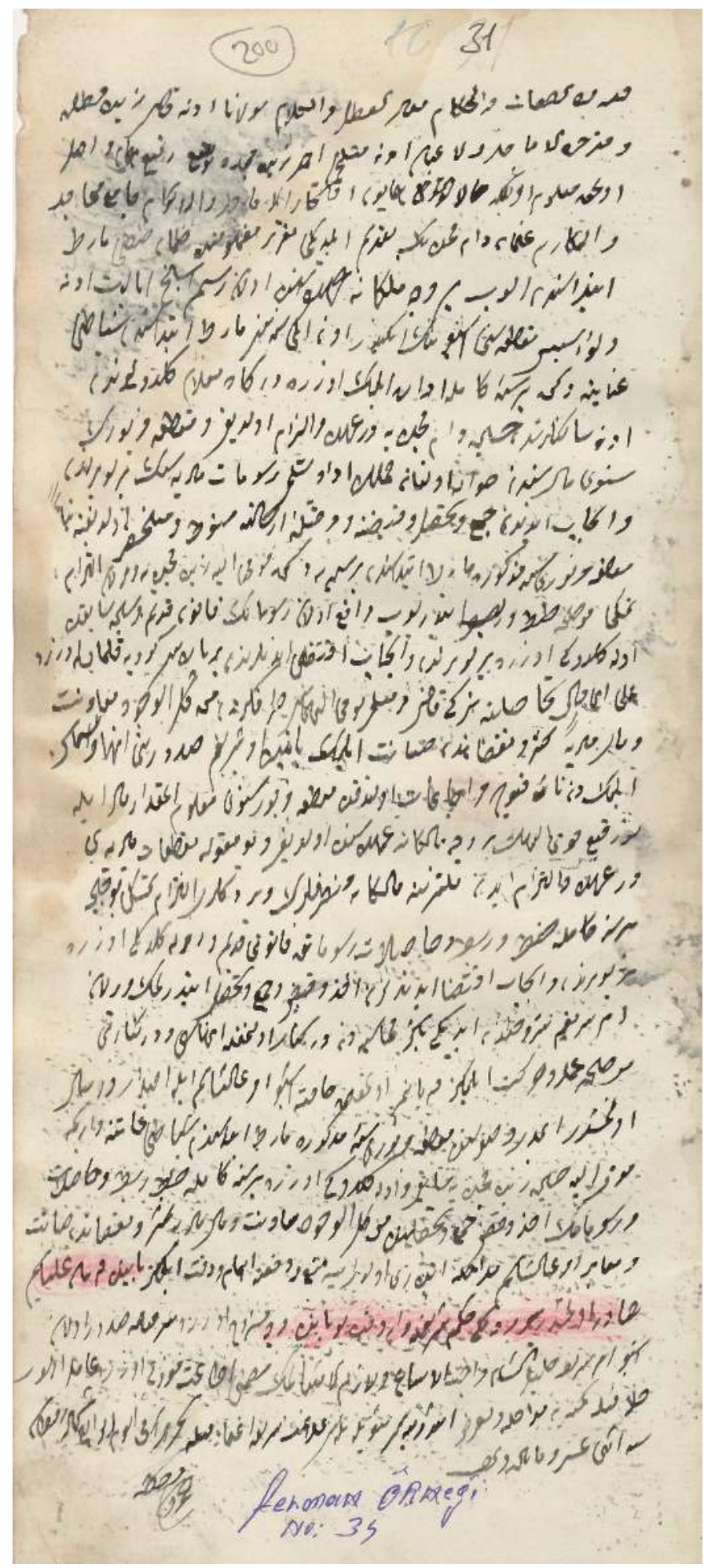

49: Adana Ş.S. 55, img. 16, sayfa 31, belge 200 


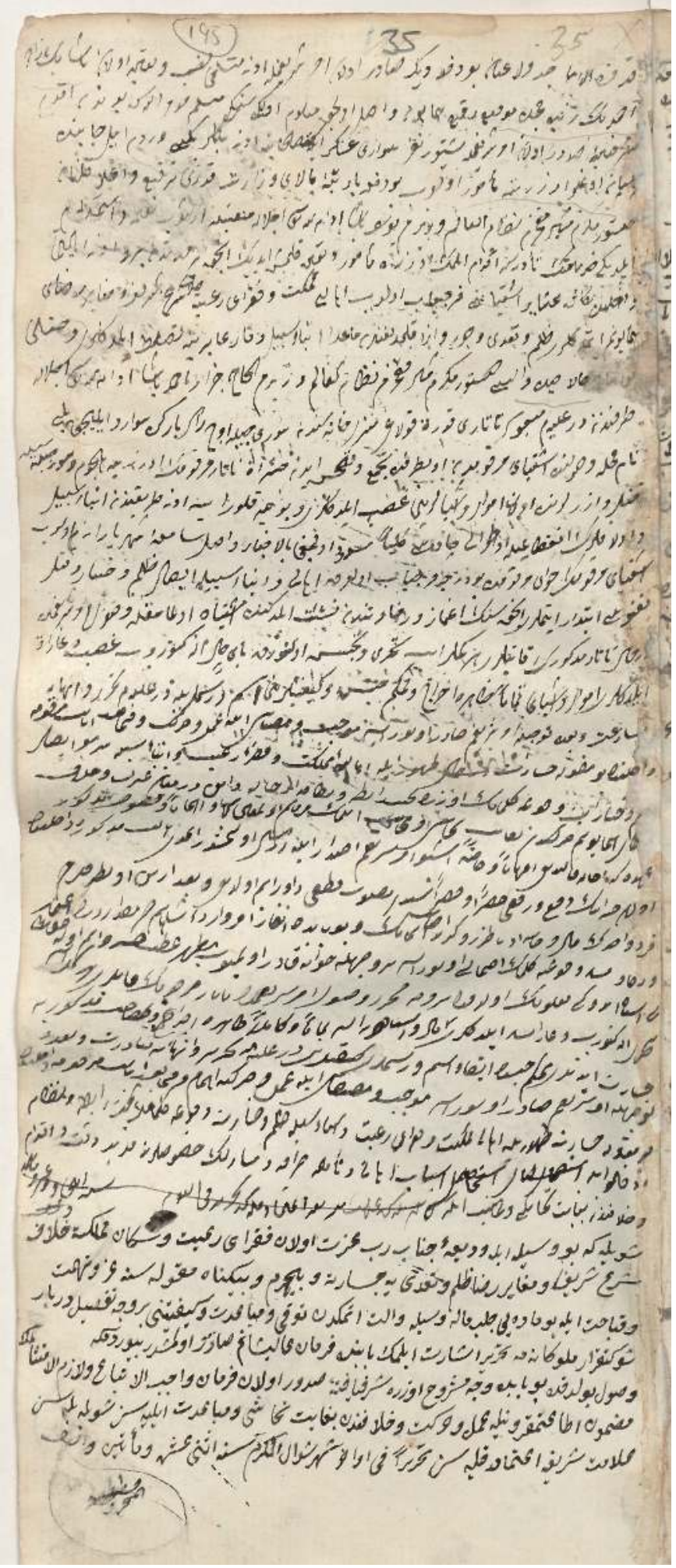

50: Adana Ş.S. 55, img. 18, sayfa 35, belge 195 


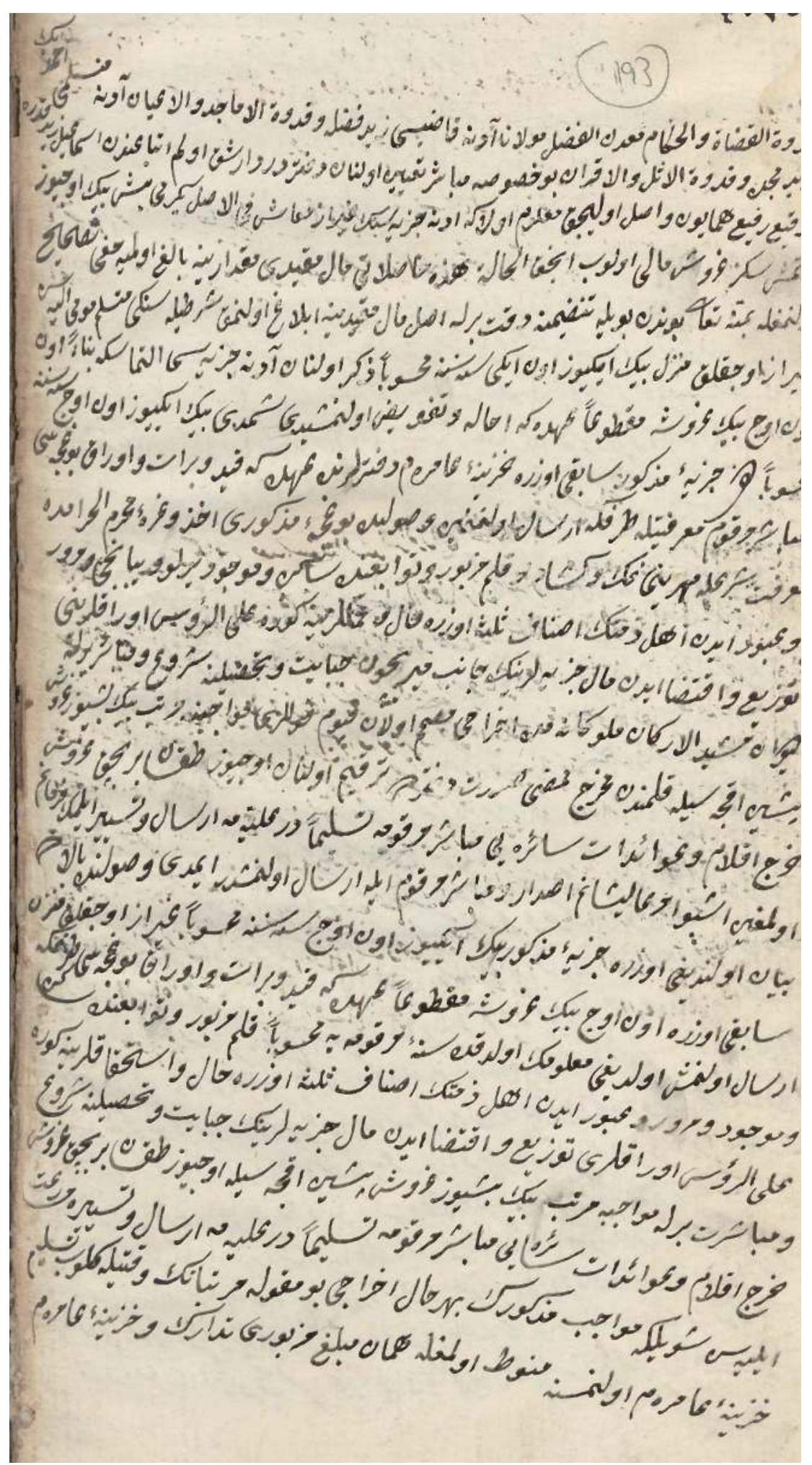

51: Adana Ş.S. 55, img. 19, sayfa 36-37, belge 193 


\section{7}

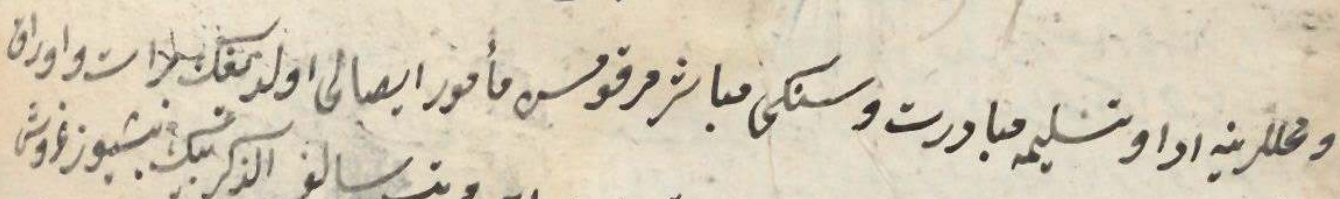

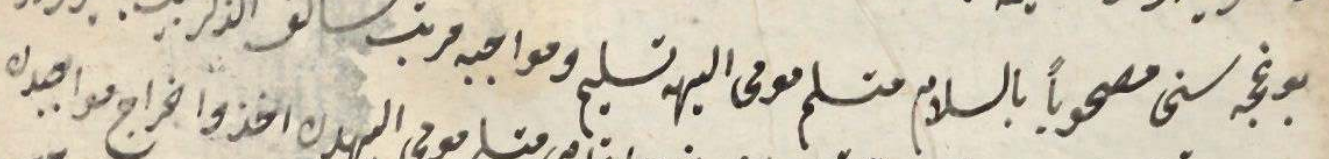

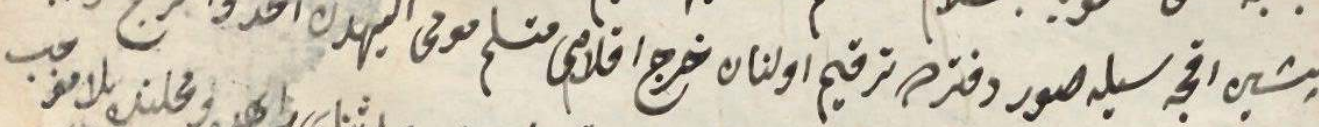

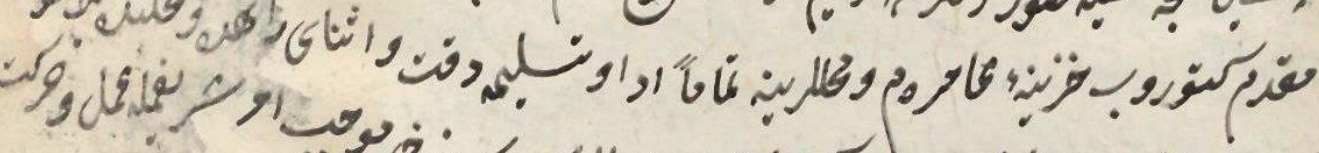

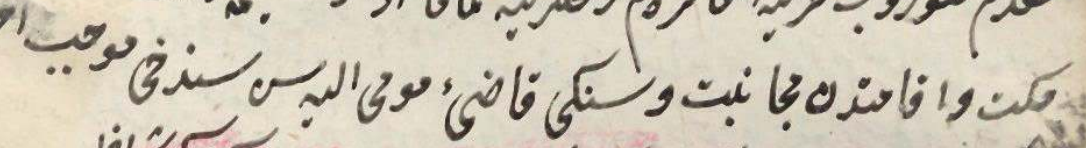

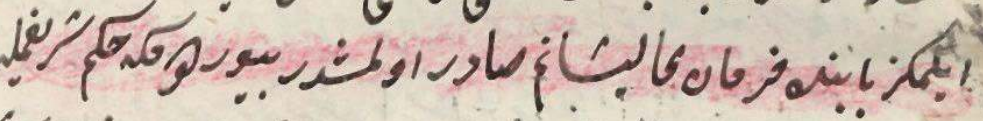

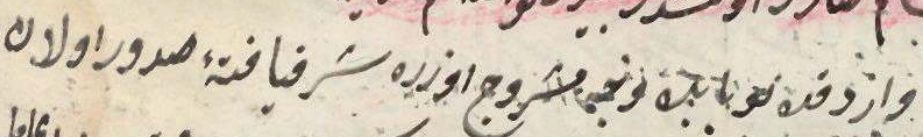

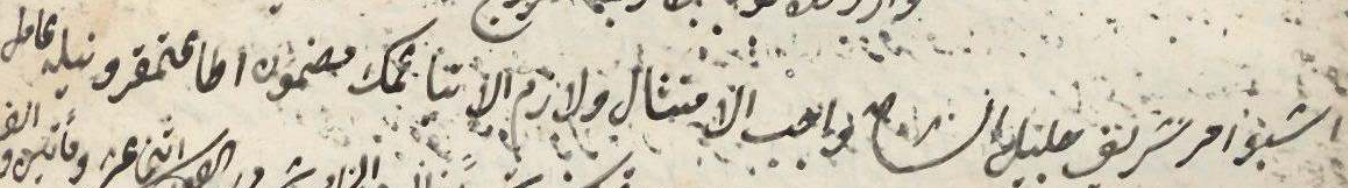

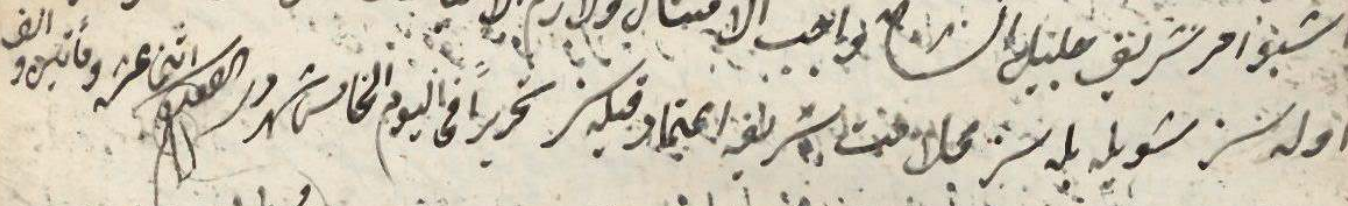

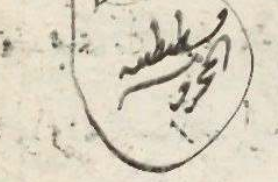

51: Adana Ş.S. 55, img. 19, sayfa 36-37, belge 193 


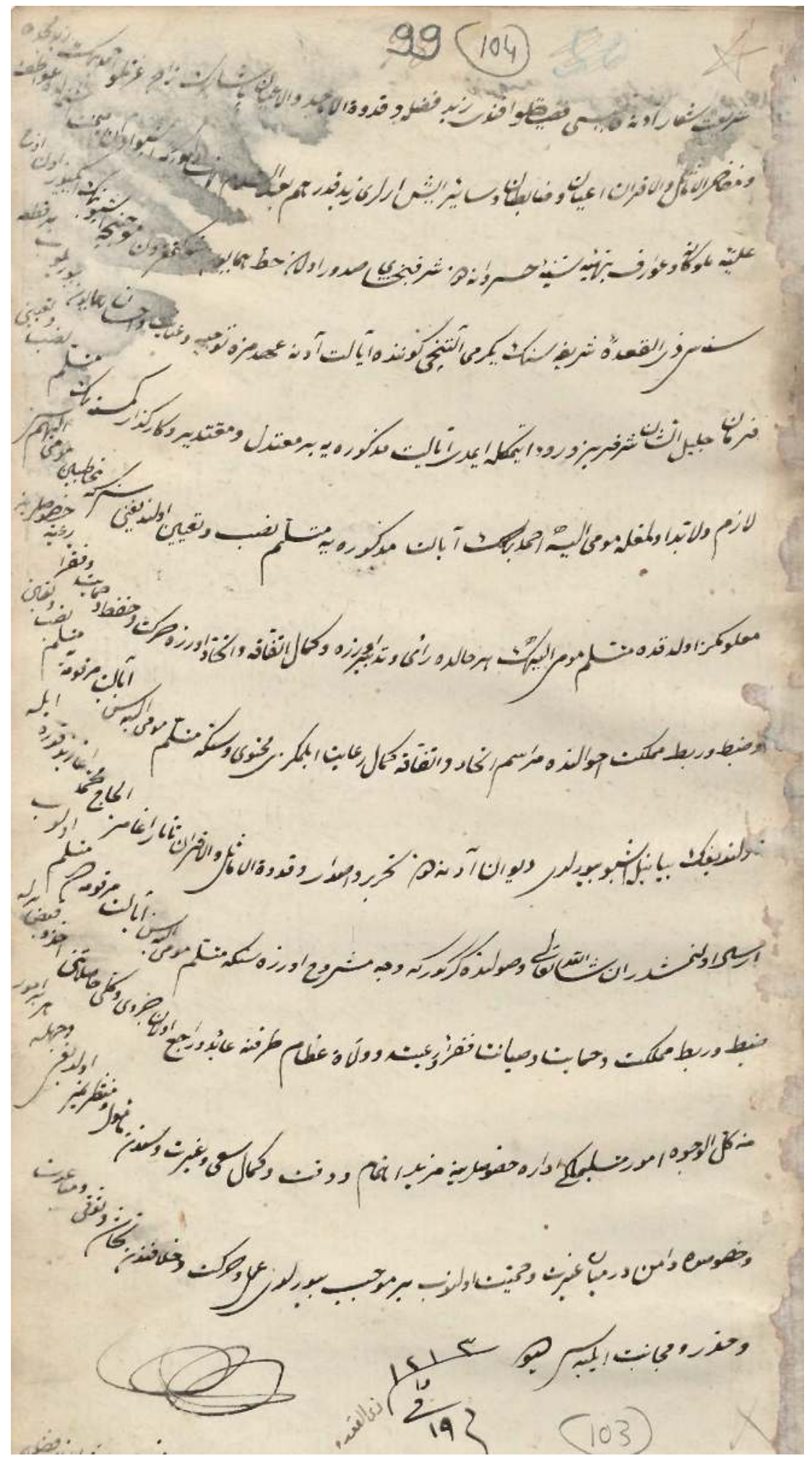

52: Adana Ş.S. 55, img. 50 sayfa 99, belge 104 


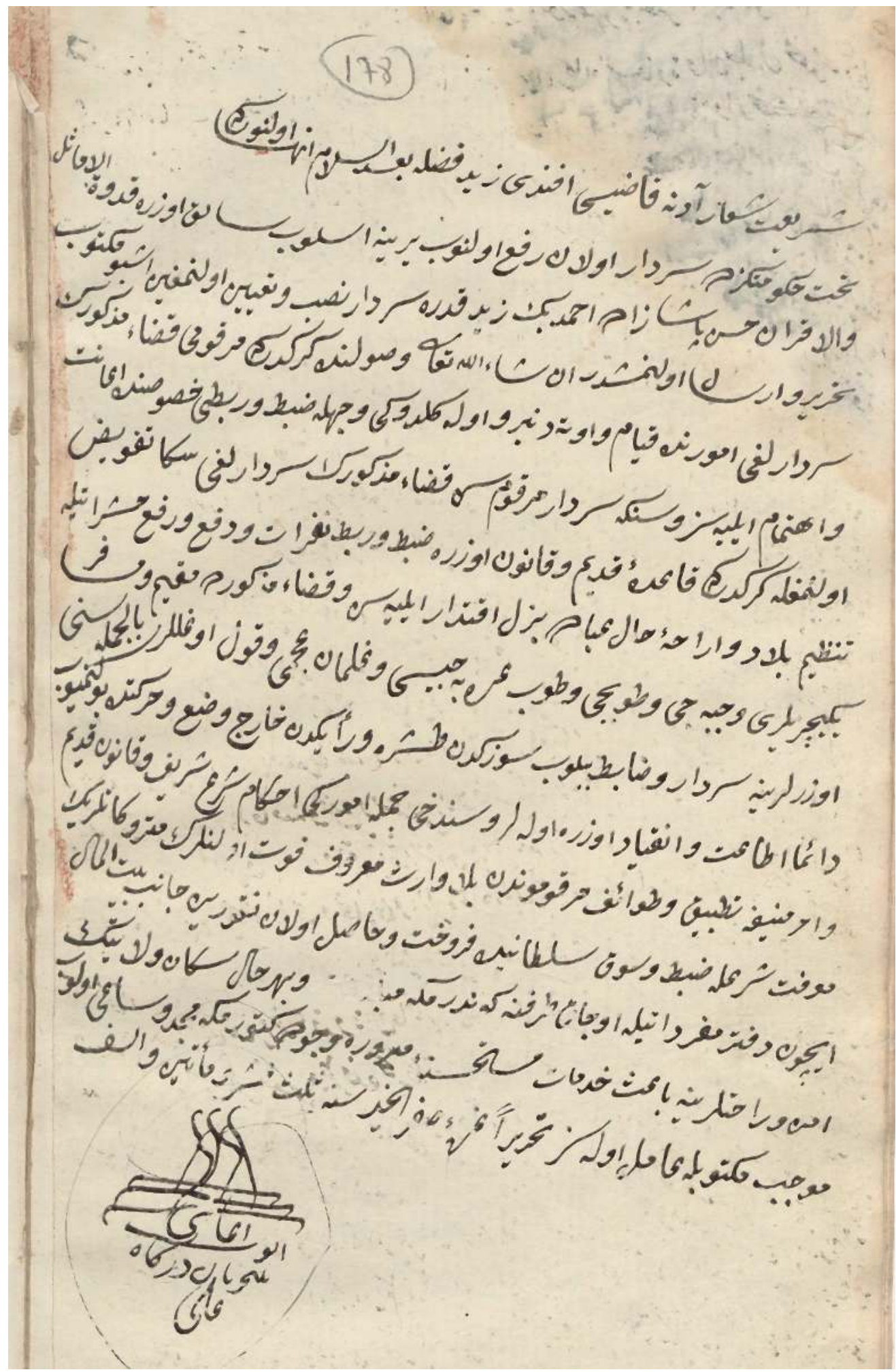

53: Adana Ş.S. 55, img. 24, sayfa 46, belge 178 


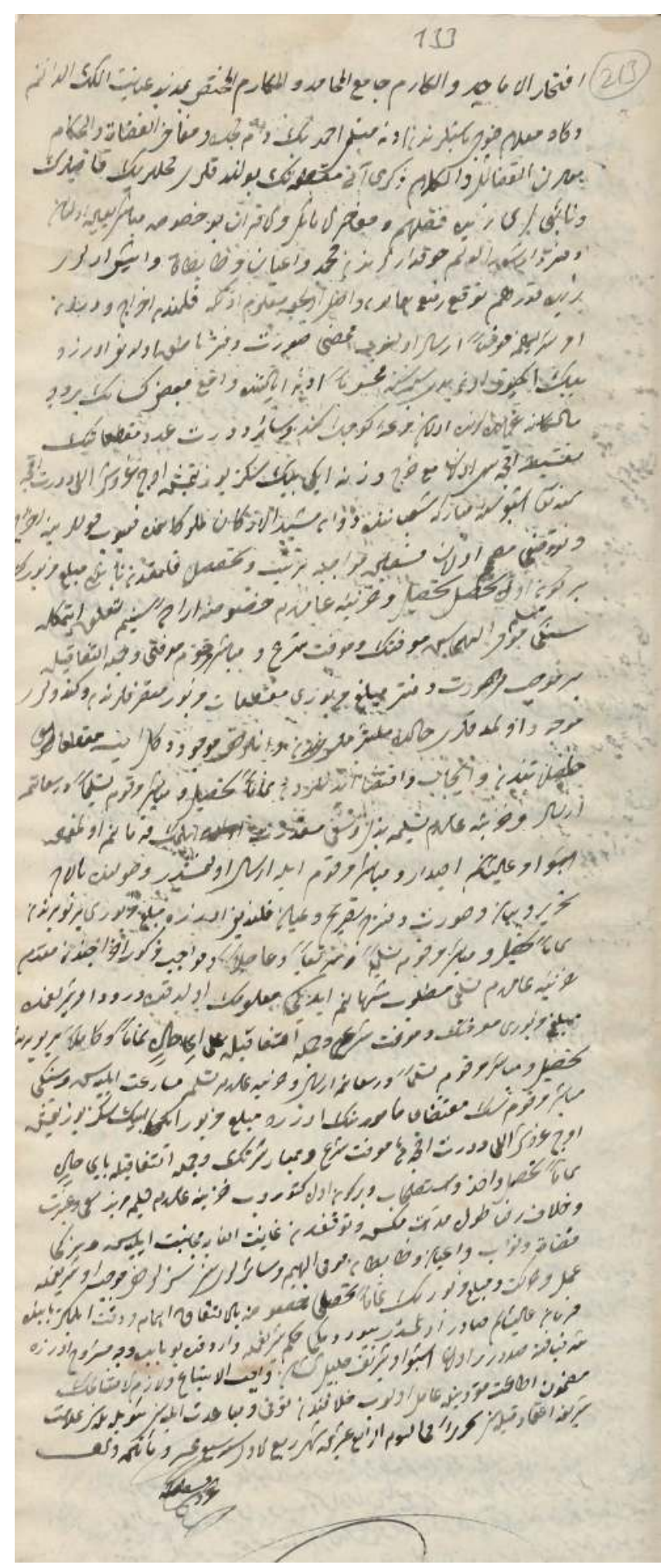

54: Adana Ş.S. 48, img. 68, sayfa 133, belge 213 


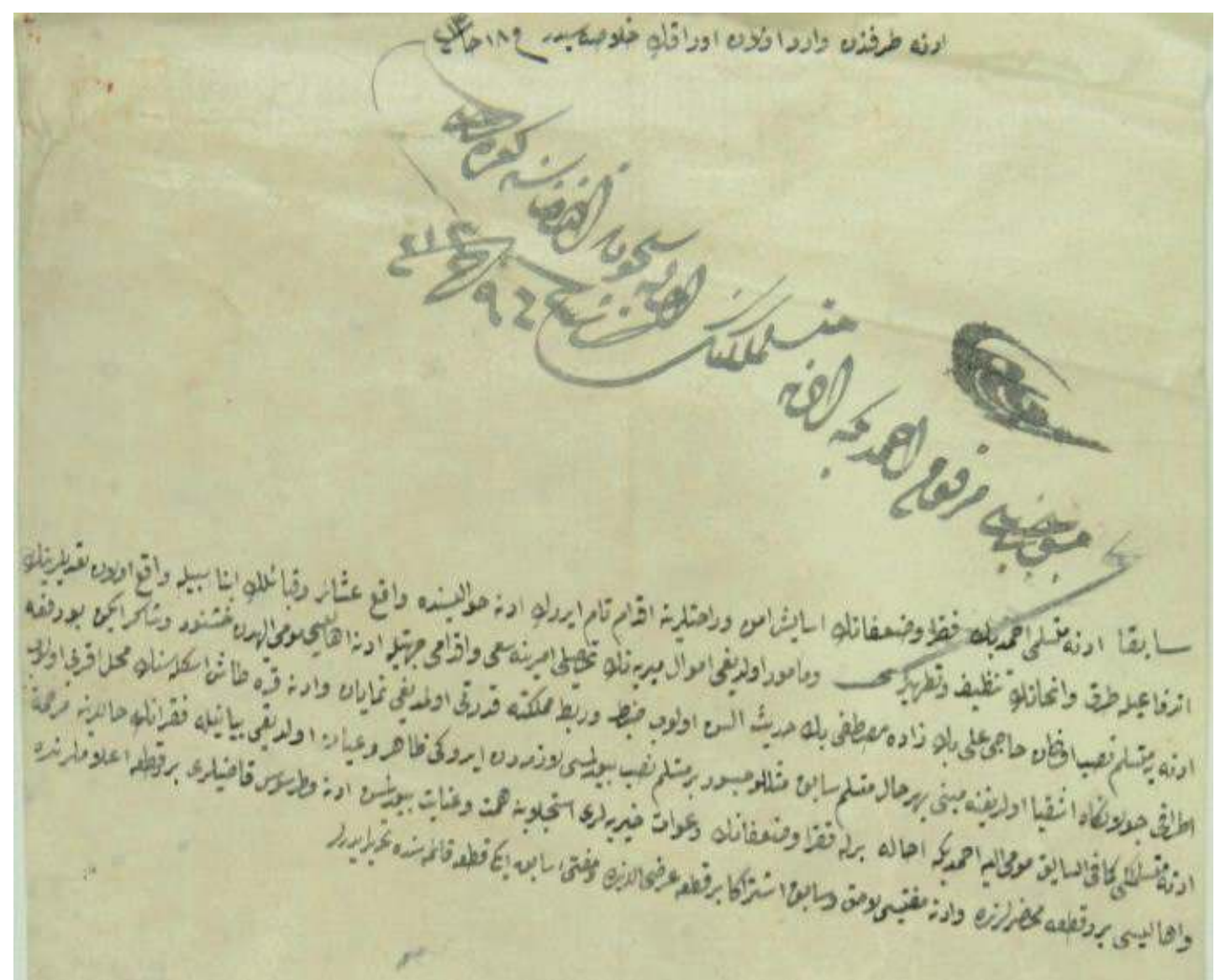

55: BOA, C. DH 25/1237 


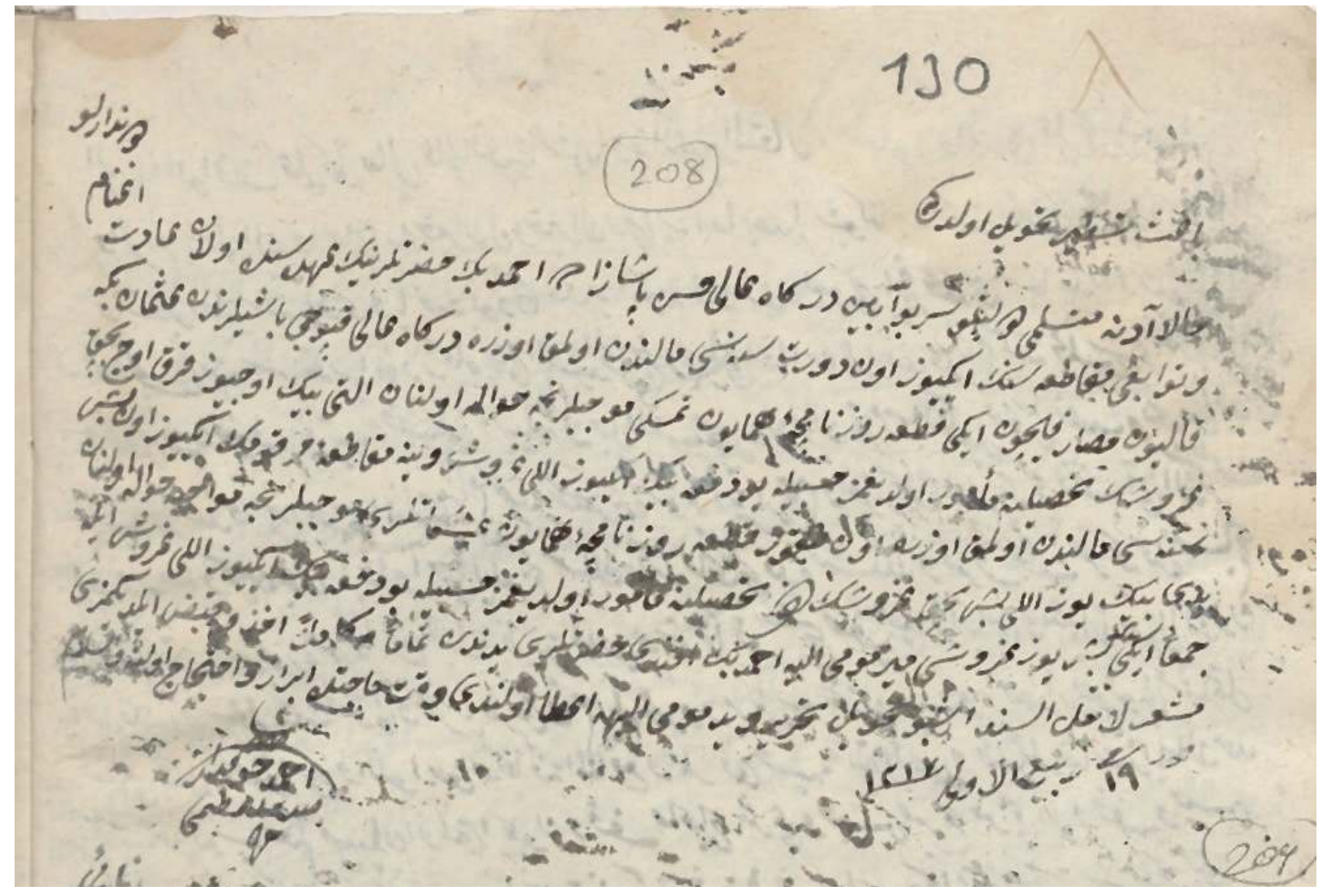

56:Adana Ş.S. 48, img. 67, sayfa 130, belge 208 


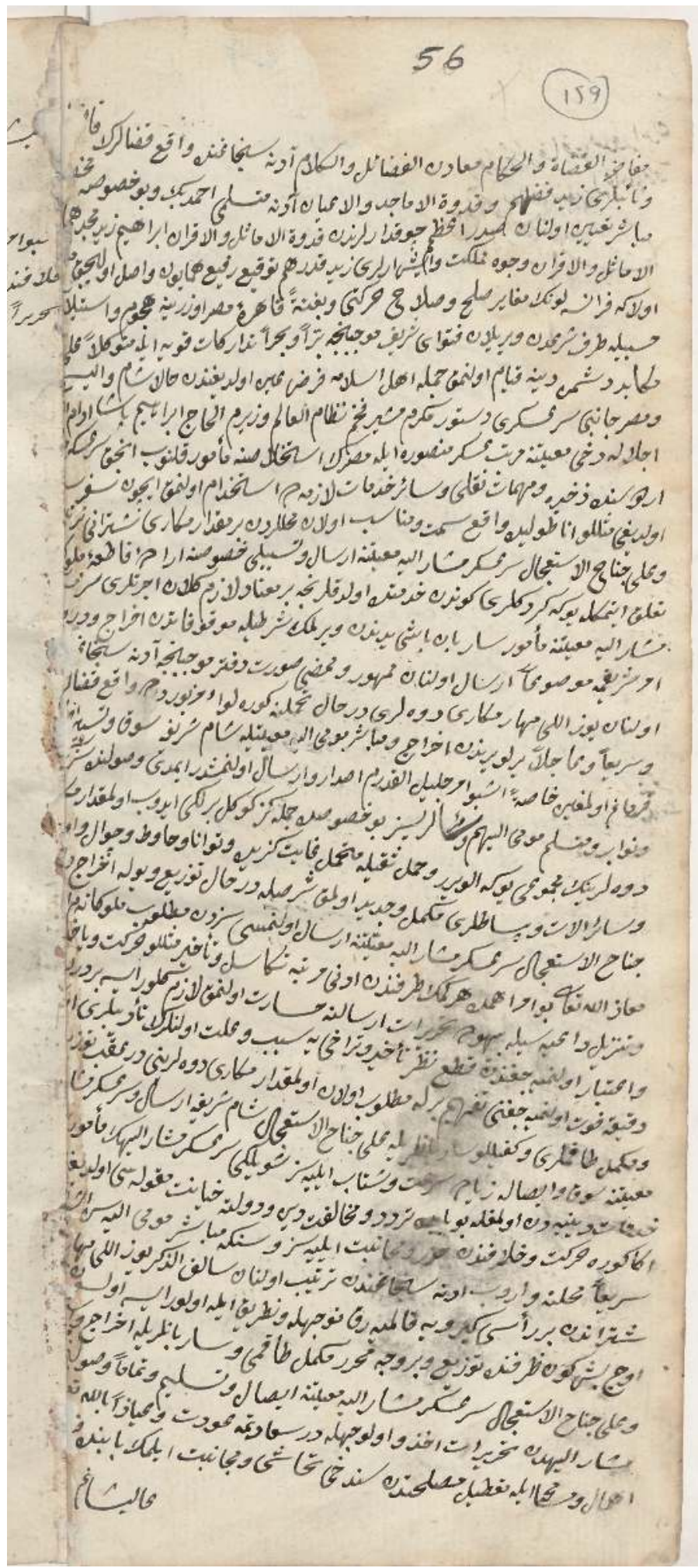

57: Adana Ş.S. 55, img. 29, sayfa 56-57, belge 158-159 


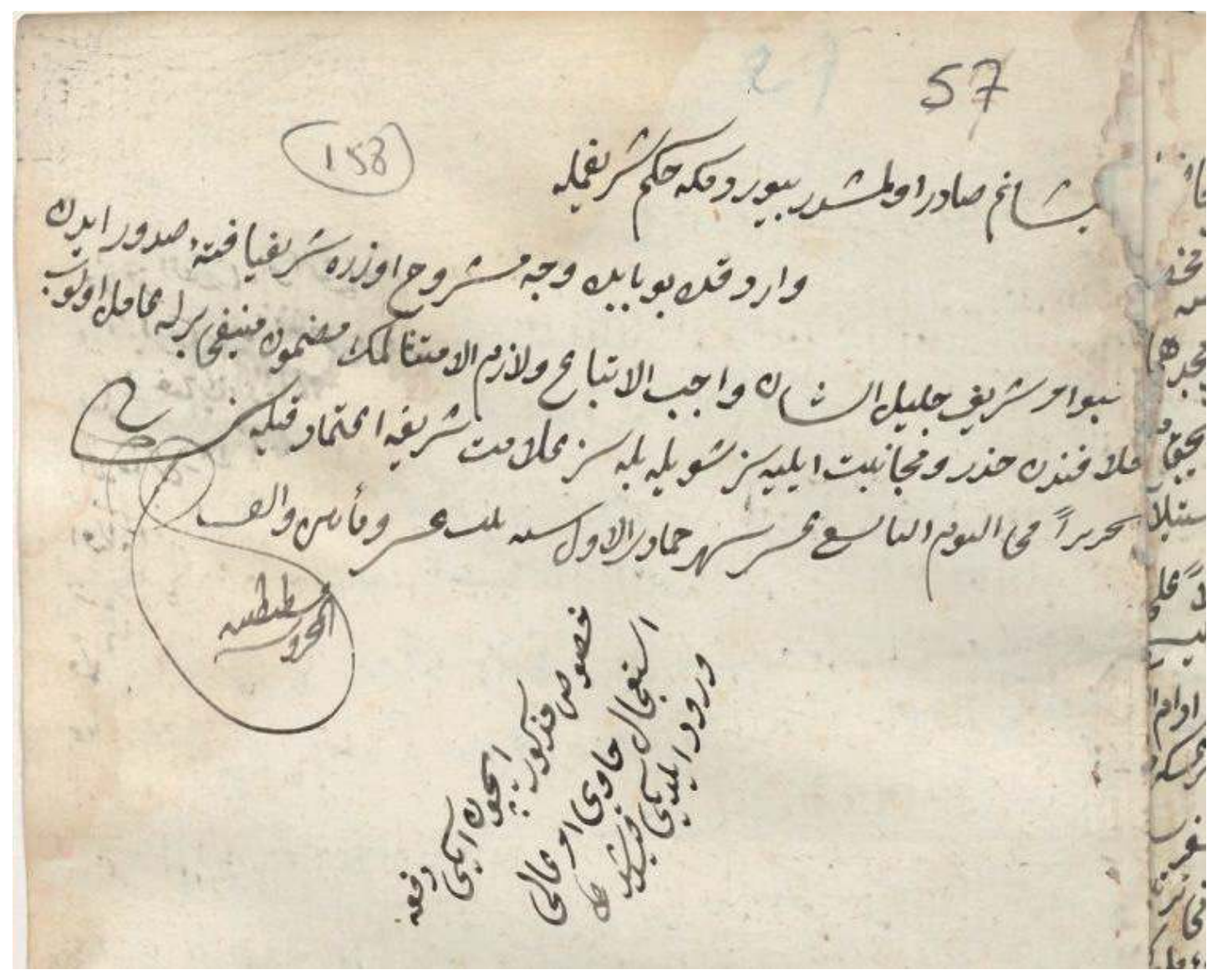

57: Adana Ş.S. 55, img. 29, sayfa 56-57, belge 158-159 


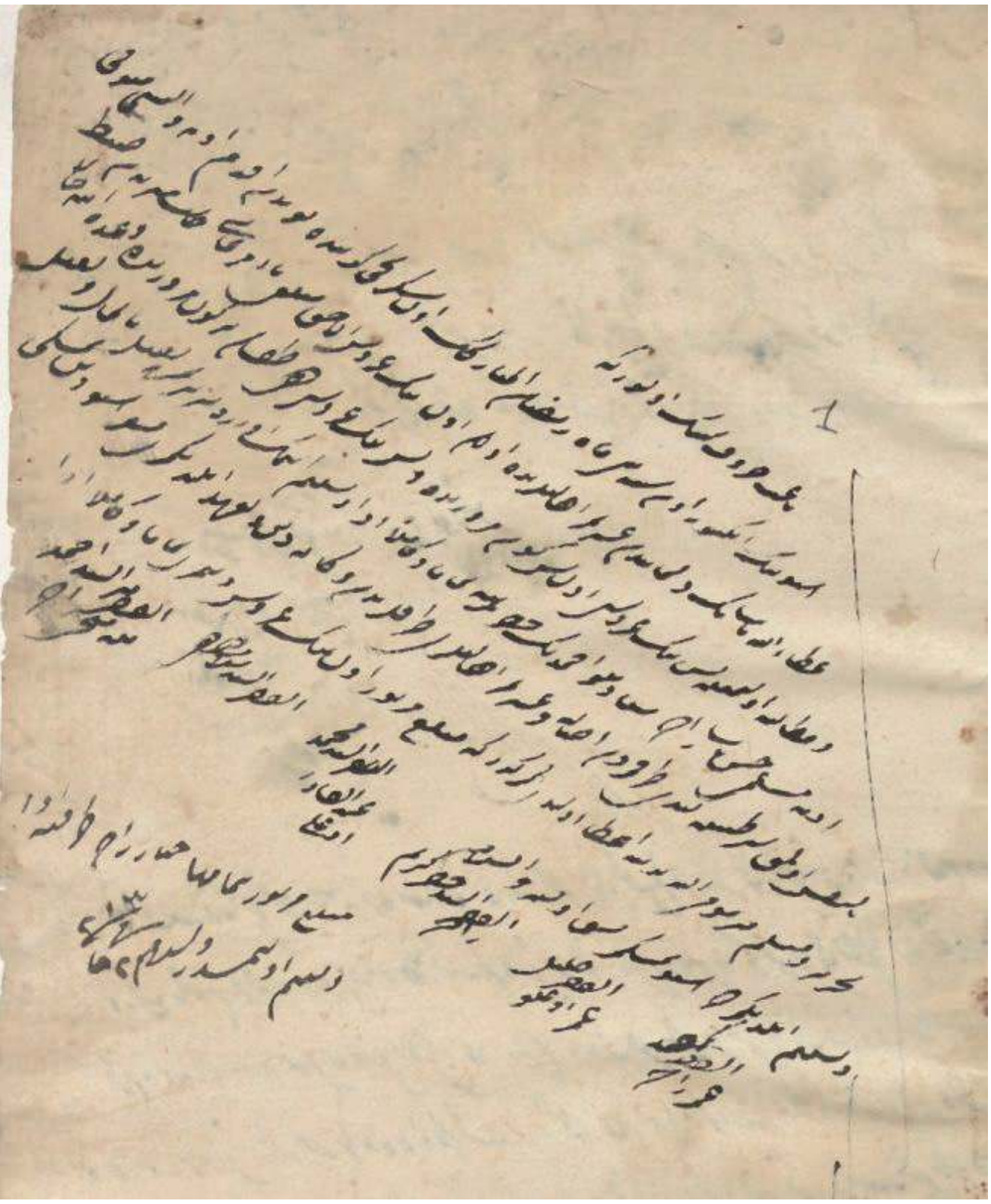

58:Adana Ş.S. 56, img. 32, sayfa 74, belge 1 


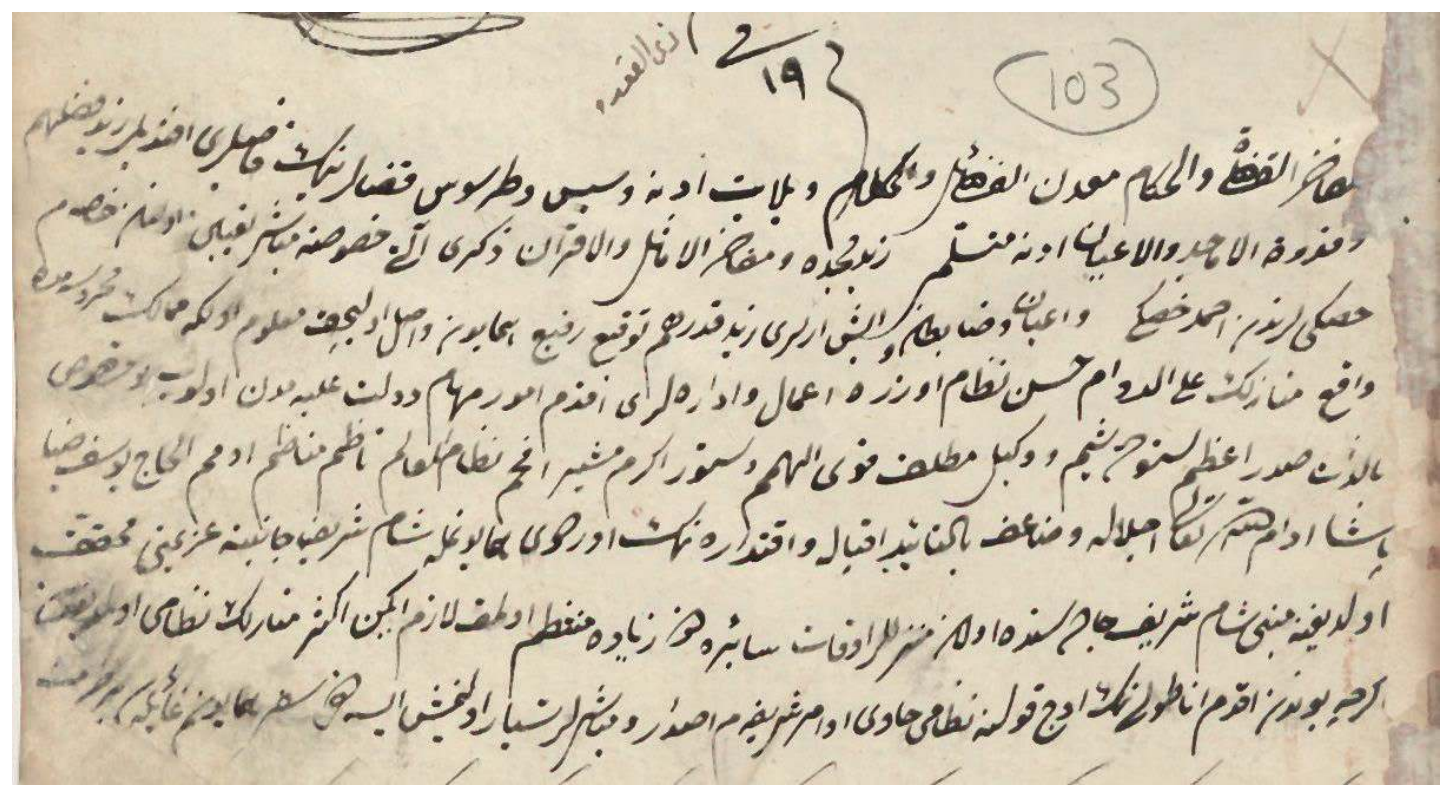

59: Adana Ş.S. 55, img. 50-51 sayfa 99-100, belge 103 


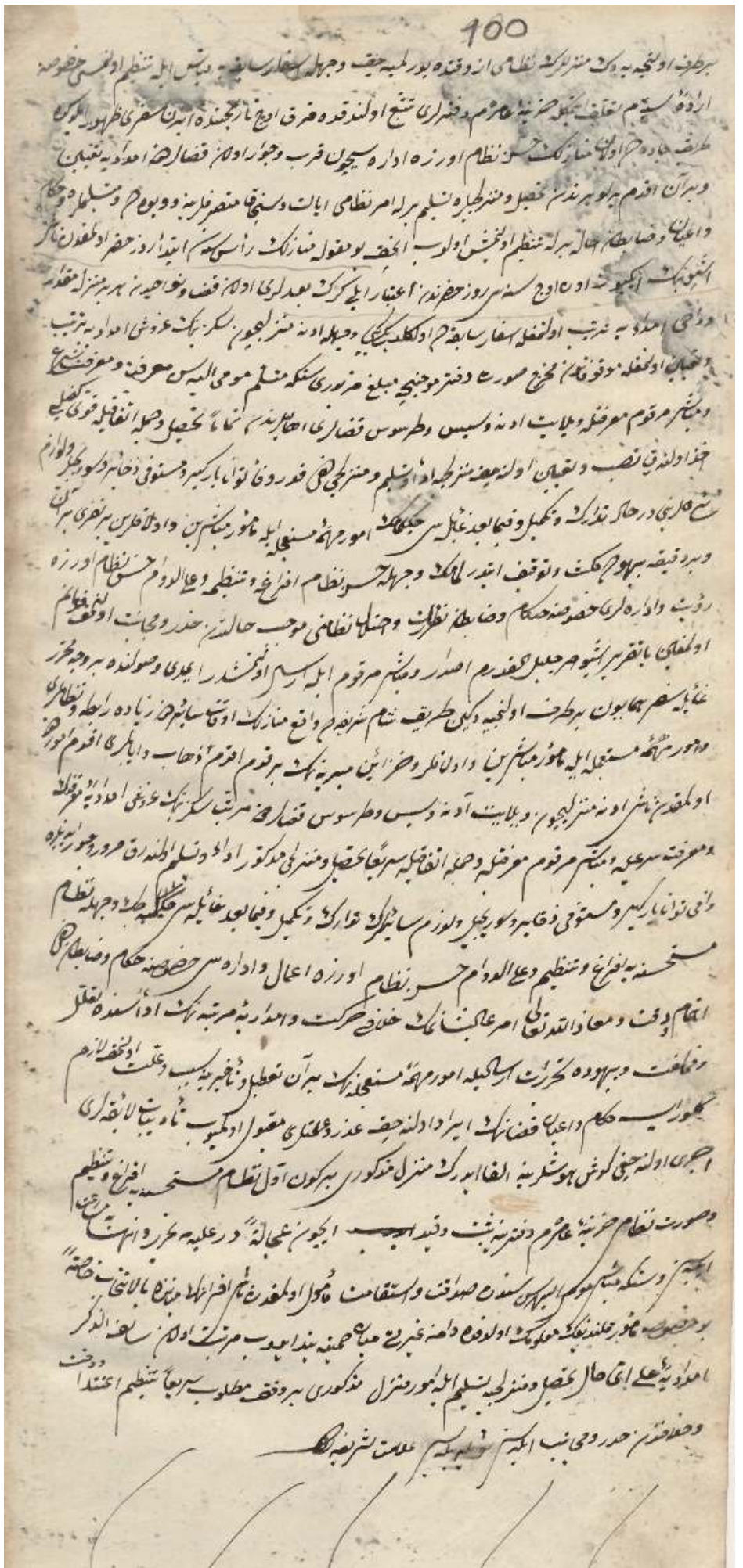

59:Adana Ş.S. 55, img. 50-51 sayfa 99-100, belge 103 


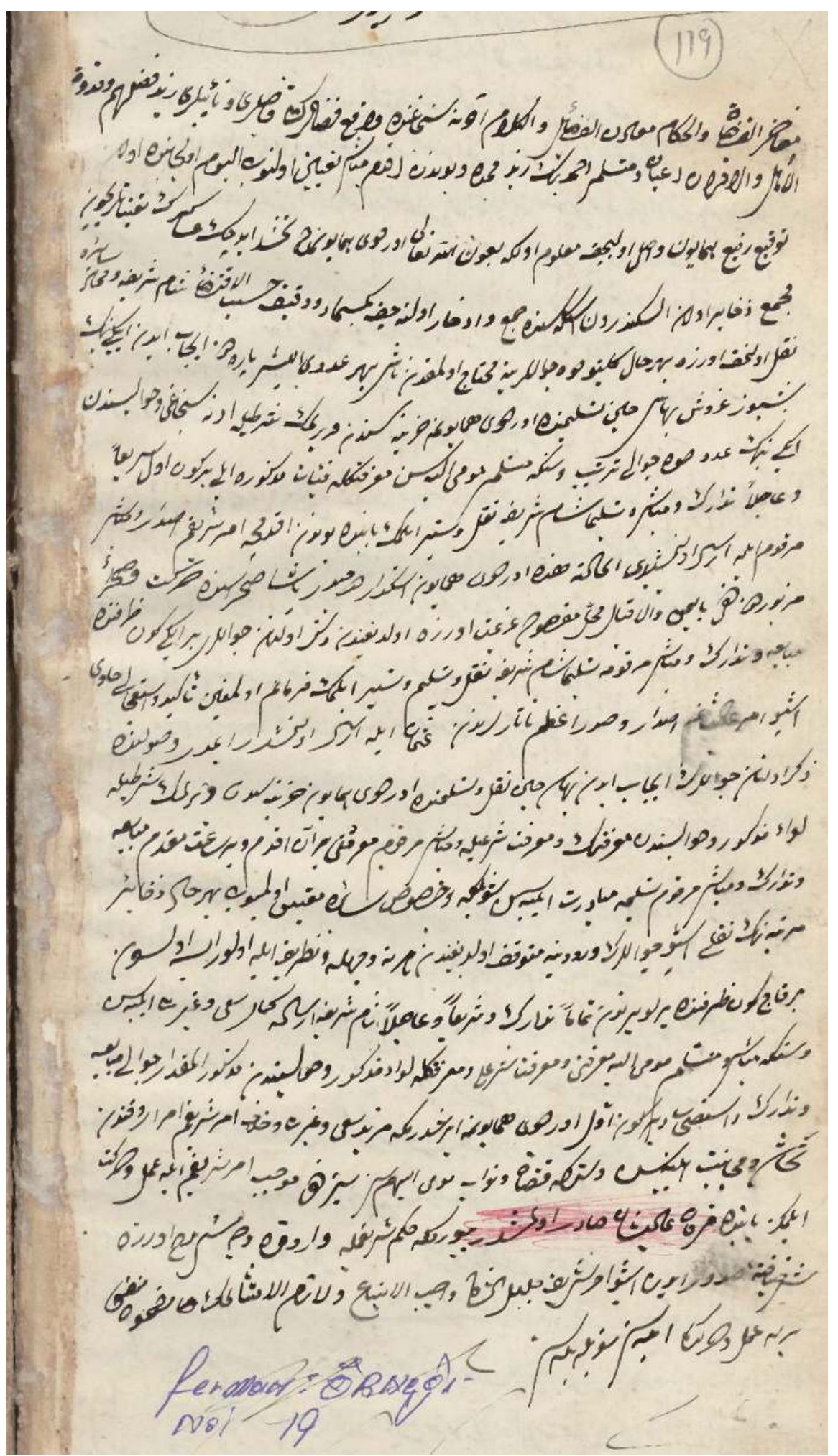

60: Adana Ş.S. 55, 42 sayfa 82, belge 119 